\title{
ESTUDO COMPARATIVO ENTRE ABRASIVOS PARA TESTE DE DESGASTE ACELERADO DE BICOS PULVERIZADORES
}

\author{
Luiz Atilio Padovan
}

Orientador: Prof. Dr. TOMAZ CAETANO CANNAVAM RIPOLI

Dissertação apresentada à Escola Superior de Agricultura "Luiz de Queiroz". Universidade de São Paulo, para a obtenção do titulo de Mestre em Agronomia. Área de Concentração: Máquinas Agricolas.

PIR A C I C AB A

Estado de São Paulo - Brasil

Janeiro - 1998 
Dados Internacionais de Catalogação na Publicação (CIP)

DIVISÃo DE BIBLIOTECA E DOCUMENTAC̣ÃO - Campus "Luiz de Queiroz"/USP

\section{Padovan, Luiz Atilio}

Estudo comparativo entre abrasivos para teste de desgaste acelerado de bicos pulverizadores / Luiz Atilio Padovan. - - Piracicaba, 1998.

134 p. : it.

Dissertaçăo (mestrado) - Escola Superior de Agricultura Luiz de Queiroz, 1998. Bibliografia.

1. Bico de pulverização 2. Ensaio de desgaste 3. Implemento agricola 4. Pulverizador 5. Resistência dos materiais l. Título. 


\section{ESTUDO COMPARATIVO ENTRE ABRASIVOS PARA TESTE DE DESGASTE ACELERADO DE BICOS PULVERIZADORES}

Aprovada em: 17.03 .98

Comissão julgadora:

Prof. Dr. Tomaz Caetano Cannavam Ripoli ESALQ/USP

Prof. Dr. José Armando Furlani Júnior FCA/UNESP

Prof. Dr. José Antonio Frizzone ESALQ/USP

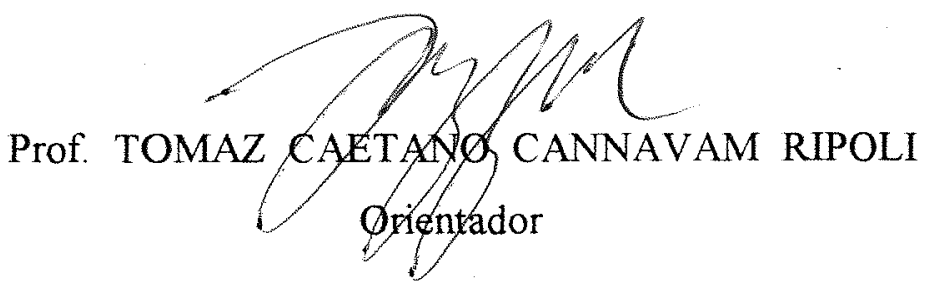




\begin{abstract}
A minha esposa Rosana e ao meu filho Felipe, pela compreensão nas muitas vezes que estive distante para realizaçào deste trabalho.
\end{abstract}

\title{
DEDICO
}

A minha filhinha, ainda na barriga da Mamãe. 


\section{AGRADECIMENTOS}

Ao Prof. Dr. Tomaz Caetano Ripoli, pela orientação, incentivo, amizade e pela confiança e liberdade em mim depositada para execução desse trabalho.

A Fundação Shunji Nishimura de tecnologia, que me acolheu e onde foram construidos os equipamentos e realizados os ensaios práticos. A todos dessa Escola que contribuíram: Sr. Shunji Nishimura, Sr. Paulo, funcionários das oficinas e do laboratório de solos e a todos os alunos que me ajudaram, em especial ao Fernando e ao Fábio.

A Empresa Jacto, pelo apoio no fornecimento das peças, componentes, bicos pulverizadores e pela utilização dos laboratórios. A todos dessa Empresa que colaboraram de uma forma ou de outra: Eng ${ }^{\circ}$ Dr. Sérgio Sartori, Eng ${ }^{\circ}$ Honda, Eng $^{\circ}$ João Fava, Emilio, Jairo, Edson Tamura e Amauri.

Ao colega e amigo Rhainer, pela imensa ajuda nas análises estatísticas, montagem e arranjo final desse trabalho.

A Empresa Spraying Systems do Brasil, pelo fornecimento dos bicos e ao Eng $^{\circ}$ José Carlos Christofoletti, por suas informações e ensinamentos e pela incansável dedicação e perseverança na melhoria da qualidade técnica das aplicações.

A Empresa Alcoa, pela doação da maioria dos materiais abrasivos e a seus funcionários Sérgio Vendrasco, Sérgio Icai, Leiva e Amélia, pelas informações e recomendações técnicas sobre os produtos.

A Empresa Rhodia, pela doação do material abrasivo e a funcionária Sandra Mara Fontolan pelas informações técnicas dos produtos. 
Ao pesquisador da Divisão de Engenharia Agricola - DEA, Hermes Geraldo Corrèa, pelas discussões, idéias e interesse no assunto e pelos materiais bibliograficos cedidos.

A CAPES, pela concessão da bolsa de estudos.

A professora Sònia, pelas sugestões na parte estatística

A bibliotecaria Katia, pela simpatia nas correções das referências bibliograficas

Aos professores desse departamento, pelos ensinamentos, amizade e compreensào

A todos os colegas do curso de P.G. em Máquinas Agricolas pela amizade e pelos bons momentos, em especial a Cristina, Ezer, Remi e Rogério

A meus Pais, pela permanente preocupação, incentivo e pelo exemplo.

A minha esposa e meu filho, pela paciência, compreensão e respeito mostrados durante todo o tempo desse curso.

A Deus. pela vida e pela oportunidade de crescer como pessoa e como profissional 


\section{SUMÁRIO}

LISTA DE FIGURAS .........................................................................

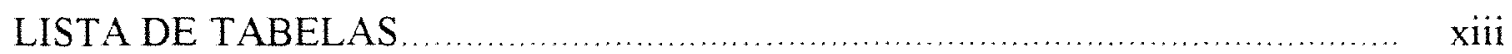

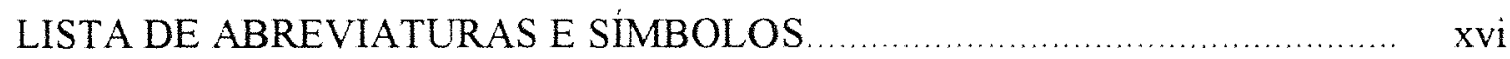

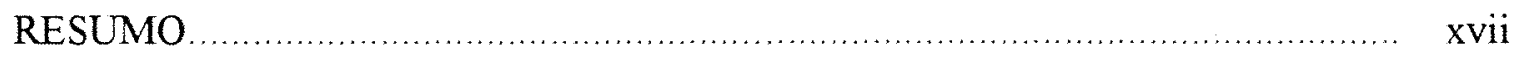

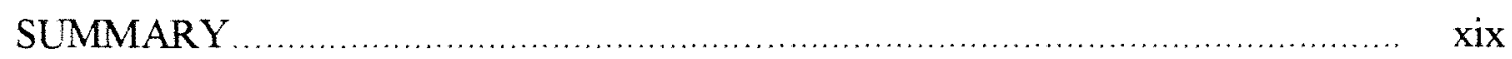

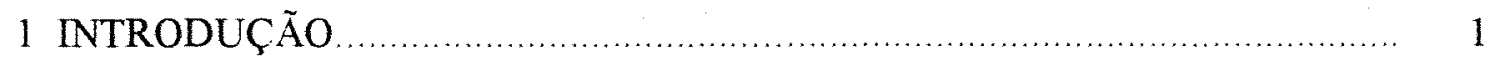

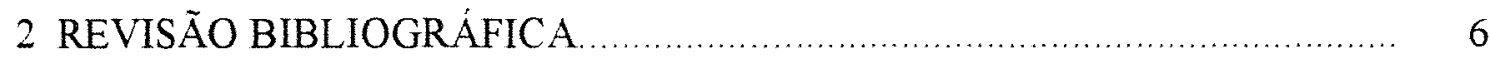

2.1 Estudo do desgaste de bicos................................................................. 6

2.2 Estudo da uniformidade da distribuição.................................................. 13

2.3 Abrasivos utilizados em testes de desgaste ............................................. 19

2.4 Abrasivos Normalizados ....................................................................... 24

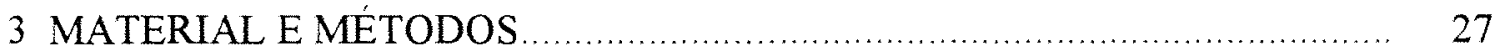

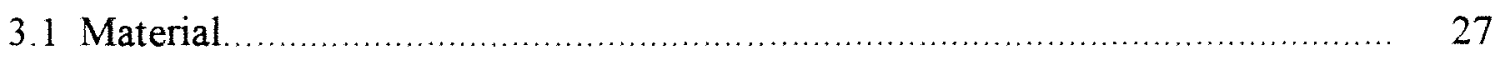

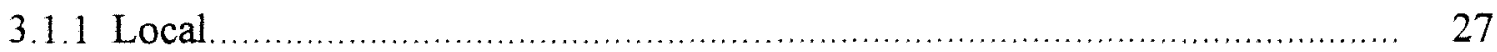

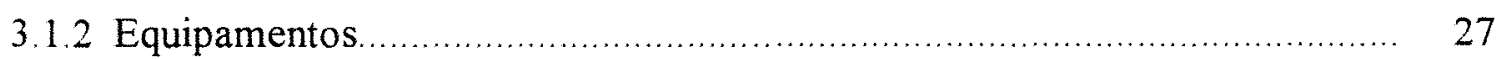

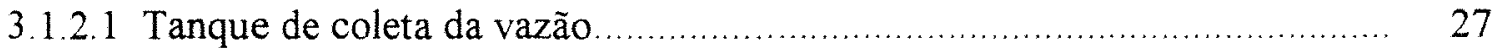

3.1.2.2 Tanque de desgaste ............................................................. 30

3.1.2.3 Mesa de canaletas..................................................................... 34

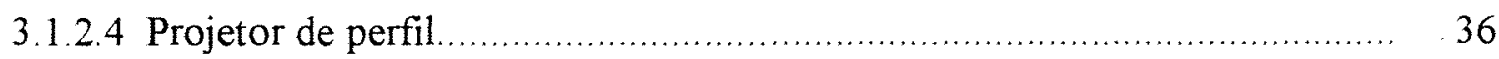

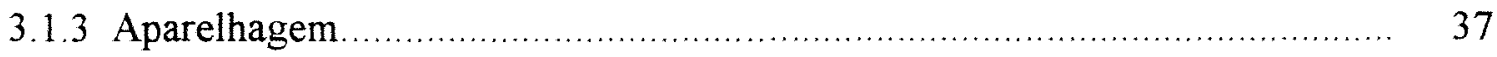

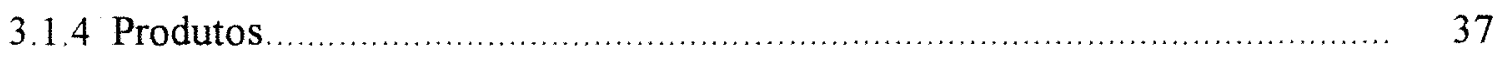

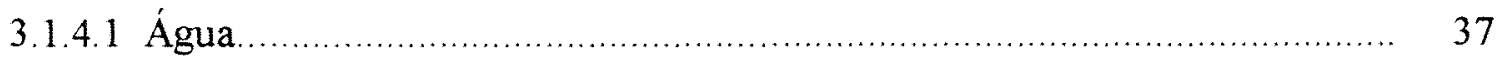


3.1.4.2 Materiais abrasivos................................................................. 38

3.1.4.3 Bicos pulverizadores de jato plano ................................................ 39

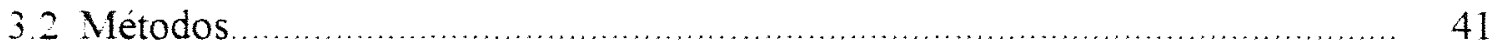

3.2.1 Seleção dos produtos abrasivos ....................................................... 41

3.2 .2 Seleção dos bicos de pulverização ................................................... 44

3.2.3 Determinação do diâmetro dos tubos da barra de pulverização ................... 45

$3.2+$ Determinação da vazão inicial dos bicos.............................................. 45

3.2 .5 Condução e avaliação dos ensaios no pré-teste...................................... 46

3.2 .6 Condução e avaliação dos ensaios no no teste final .............................. 47

3 26.1 Determinação dos tempos para alcançar os níveis de desgaste................. 48

3.2.6.2 Determinação dos diâmetros da elipse ................................................. 49

3.2.6.3 Determinação do perfil de distribuição ................................................ 50

4 RESULTADOS E DISCUSSÃO ........................................................... 52

4.1 Avaliação do diâmetro dos tubos da barra de pulverização........................... 52

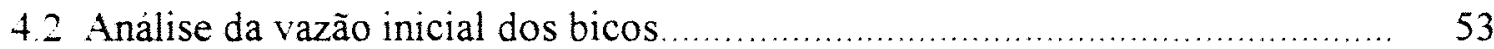

4.3 Avaliação dos ensaios no pré-teste ...................................................... 57

4.3.1 Análise do aumento porcentual da vazão dos bicos sob a ação abrasiva...... 57

4.3 .2 Analise dos bicos por abrasivo........................................................ 67

4.3.3 Análise dos abrasivos por bico ..................................................... 77

4.3.4 Resistència relativa dos bicos ........................................................ 82

4.4 Avaliação dos ensaios no teste final........................................................ 85

4.4.1 Análise dos tempos para os níveis de desgaste ........................................ 85

4.4.2 Análise dos diâmetros da elipse....................................................... 89

4.4.3 Estudo da uniformidade de distribuição.................................................. 95

4.4.3.1 Avaliação do perfil de distribuição..................................................... 95

4.4.3.2 Avaliação do CV da uniformidade da distribuição .................................. 99

4.4.3.3 Comportamento do $\mathrm{CV}$ para cada canaleta nos diferentes niveis de desgaste. 
Página

4.4.3.4 Avaliação da simetria volumétrica da distribuição

4.4.3.5 Avaliação do ângulo do jato. 110

5 CONCLUSÕES 112

REFERÈNCIAS BIBLIOGRÁFICAS 114

APENNDICE 


\section{LISTA DE FIGURAS}

1 Vista parcial do tanque de coleta da vazão.

Página

2 Esquema de funcionamento do tanque de coleta da vazão 28

3 Vista parcial do tanque de desgaste: (a) Vista de topo; (b) Vista lateral. 29

+ Esquema de funcionamento dos circuitos do tanque de desgaste 32

5 Vista parcial da mesa de canaletas 33

6 Esquema de detalhes da mesa de canaletas. 34

7 Vista parcial do projetor de perfil 35

8 Materiais abrasivos utilizados no presente estudo. 36

9 Vista parcial dos bicos de jato plano utilizado no presente estudo 39

10 Esquema explicativo da obtenção do CV. 40

11 Gráfico da variação da vazão dos bicos, para os diferentes diâmetros do tubo da barra de pulverização

12 Gráfico do aumento porcentual da vazão em função do tempo sob a ação do abrasivo Corindon - grão 800

13 Gráfico do aumento porcentual da vazão em função do tempo sob a ação do abrasivo Carbeto de Silicio - SIC 800.

14 Gráfico do aumento porcentual da vazão em função do tempo sob a ação do abrasivo Caulim O.B. 2150

15 Gráfico do aumento porcentual da vazão em função do tempo sob a ação do abrasivo Alumina Calcinada APC 2011 SG.

16 Gráfico do aumento porcentual da vazão em função do tempo sob a ação do abrasivo Carbeto de Silicio - SIC 240. 
17 Gráfico do aumento porcentual da vazão em função do tempo sob a ação do abrasivo Carbeto de Silício - SIC 500. 70

18 Gráfico do aumento porcentual da vazão em função do tempo sob a ação do abrasivo Óxido de Alumínio Branco (FFF)

19 Gráfico do aumento porcentual da vazão em função do tempo sob a ação do abrasivo Bióxido de Silício - Tixosil 73

20 Gráfico do aumento porcentual da vazão em função do tempo sob a ação do abrasivo Areia de Fundição para Shellmold.

21 Gráfico do aumento porcentual da vazão em função do tempo para o bico de ceràmica XR 78

22 Gráfico do aumento porcentual da vazão em função do tempo para o bico de ceràmica $\mathrm{ADI}$ 78

23 Gráfico do aumento porcentual da vazão em função do tempo para o bico de kematal UF

24 Gráfico do aumento porcentual da vazão em função do tempo para o bico de kematal LD

25 Gráfico do aumento porcentual da vazão em função do tempo para o bico de aço inox XR.

26 Gráfico do aumento porcentual da vazão em função do tempo para o bico de aço inox DG

27 Gráficos comparativos do aumento percentual da vazão sob ação do abrasivo Óxido de Alumínio Branco (FFF) entre os ensaios Pré-Teste (a)

e Teste Final (b)

28 Gráfico do aumento dos diâmetros maior $(\mathrm{X})$ e menor $(\mathrm{Y})$ da elipse $(\mathrm{mm})$ em função dos níveis de desgaste $(\%)$.

29 Vista em detalhe do orificio do bico novo e após o teste. (a) cerâmica $\mathrm{XR}$, (b) cerâmica ADI e (c) kematal UF. 
30 Vista em detalhe do orificio do bico novo e após o teste. (a) kematal LD,

(b) aço inox XR e (c) aço inox DG

31 Grafico do perfil de distribuição do bico de cerâmica XR, nos diferentes niveis de desgaste

32 Grafico do perfil de distribuição do bico de ceràmica ADI, nos diferentes niveis de desgaste.

33 Gráfico do perfil de distribuição do bico de kematal UF, nos diferentes niveis de desgaste.

34 Grafico do perfil de distribuição do bico de kematal LD, nos diferentes niveis de desgaste.

35 Gráfico do perfil de distribuição do bico de aço inox XR, nos diferentes niveis de desgaste.

36 Gráfico do perfil de distribuição do bico de aço inox $D G$, nos diferentes niveis de desgaste.

37 Gráfico da variação do $\mathrm{CV}$ em função dos niveis de desgaste para os diferentes bicos.

38 Comportamento dos aumentos porcentuais da vazão e do CV em função do tempo de desgaste, para os bicos: cerâmica XR (a), cerâmica ADI (b), kematal UF (c), kematal LD (d), aço inox XR (e) e aço inox DG (f). 103

39 Comportamento do $\mathrm{CV}$ das três repetições de cada canaleta para os diferentes níveis de desgaste, para os bicos: cerâmica XR (a), cerâmica ADI (b), kematal UF (c), kematal LD (d), aço inox XR (e) e aço inox $\mathrm{DG}(\mathrm{f})$

40 Gráfico do comportamento dos ângulos dos bicos nos diferentes niveis de desgaste. 


\section{LISTA DE TABELAS}

1 Vazão média do exemplar obtida através de três repetições de leitura (V/min à pressão de 40 psi) e vazão média, coeficiente de variação (CV), vazão nominal e desvio médio (\%) dos tipos de bicos.

2 Médias do aumento porcentual da vazão para cada um dos tipos de bicos em função do tempo, sob a ação do abrasivo Coríndon - grão 800 , com aplicação de Tukey a 5\%.

3 Médias do aumento porcentual da vazão para cada um dos tipos de bicos em função do tempo, sob a ação do abrasivo Carbeto de Silício - SIC 800 , com aplicação de Tukey a $5 \%$

4 Médias do aumento porcentual da vazão para cada um dos tipos de bicos em função do tempo, sob a ação do abrasivo Caulim O. B. 2150, com aplicação de Tukey a $5 \%$

5 Médias do aumento porcentual da vazão para cada um dos tipos de bicos em função do tempo, sob a ação do abrasivo Alumina Calcinada APC 2011 SG, com aplicação de Tukey a 5\%.

6 Médias do aumento porcentual da vazão para cada um dos tipos de bicos em função do tempo, sob a ação do abrasivo Carbeto de Silício - SIC 240, com aplicação de Tukey a 5\%

7 Médias do aumento porcentual da vazão para cada um dos tipos de bicos em função do tempo, sob a ação do abrasivo Carbeto de Silício - SIC 500 , com aplicação de Tukey a $5 \%$ 
8 Médias do aumento porcentual da vazão para cada um dos tipos de bicos em função do tempo, sob a ação do abrasivo Óxido de Alumínio Branco (FFF), com aplicação de Tukey a 5\%

9 Médias do aumento porcentual da vazão para cada um dos tipos de bicos em função do tempo, sob a ação do abrasivo Bióxido de Silício Tixosil 73, com aplicação de Tukey a 5\%..

10 Médias do aumento porcentual da vazão para cada um dos tipos de bicos em função do tempo, sob a ação do abrasivo Areia de Fundição para Shellmold, com aplicação de Tukey a 5\%.

11 Variâncias médias dos aumentos porcentuais da vazão dos bicos por tempo para cada um dos abrasivos.

12 Equações de regressão para cada um dos seis bicos testados sob a ação dos diferentes abrasivos, relacionando o aumento da vazão (Y) em porcentagem e o tempo $(X)$ em horas.

13 Comparação relativa entre os aumentos porcentuais da vazão dos bicos para cada abrasivo.

14 Comparação relativa entre os aumentos porcentuais da vazão entre bicos de baixa deriva e uso ampliado de cada material, para cada abrasivo.

15 Médias do tempo para alcançar determinados niveis de desgaste dos bicos sob a ação do abrasivo Óxido de Alumínio Branco (FFF), com aplicação de Tukey a $5 \%$.

16 Equações de regressão linear para cada um dos seis bicos testados sob o abrasivo Óxido de Alumínio Branco (FFF), relacionando o nível de desgaste $(x)$ e o tempo $(y)$

17 Médias do aumento do diâmetro maior da elipse $(X)(\mathrm{mm})$ em função dos níveis de desgaste, para cada bico, com aplicação do teste de Tukey a $5 \%$. 
18 Médias do aumento do diâmetro menor da elipse (Y) (mm) em função dos niveis de desgaste, para cada bico, com aplicação do teste de Tukey a $5 \%$. 90

19 Equações de regressão linear, relacionando o nível de desgaste (\%) (y) e o diâmetro maior da elipse (variável $X$, em $\mathrm{mm}$ ) e o diâmetro menor da elipse (variável $\mathrm{Y}$, em mm), para cada um dos seis bicos testados......

20 Coeficientes de variação dos seis bicos para diferentes niveis de desgaste (N.D.) para o abrasivo Óxido de Alumínio Branco (FFF).

21 Distribuição da vazão $(\mathrm{ml})$ para os lados direito e esquerdo, diferença porcentual, volume médio total e tempo médio de coleta para o bico de ceràmica $\mathrm{XR}$, nos diferentes niveis de desgaste.

22 Distribuição da vazão $(\mathrm{ml})$ para os lados direito e esquerdo, diferença porcentual, volume médio total e tempo médio de coleta para o bico de cerâmica $\mathrm{ADI}$, nos diferentes niveis de desgaste.

23 Distribuição da vazão $(\mathrm{ml})$ para os lados direito e esquerdo, diferença porcentual, volume médio total e tempo médio de coleta para o bico de kematal UF, nos diferentes niveis de desgaste. 108

24 Distribuição da vazão $(\mathrm{ml})$ para os lados direito e esquerdo, diferença porcentual, volume médio total e tempo médio de coleta para o bico de kematal LD, nos diferentes niveis de desgaste. 108

25 Distribuição da vazão $(\mathrm{ml})$ para os lados direito e esquerdo, diferença porcentual, volume médio total e tempo médio de coleta para o bico de aço inox XR, nos diferentes niveis de desgaste.

26 Distribuição da vazão $(\mathrm{ml})$ para os lados direito e esquerdo, diferença porcentual, volume médio total e tempo médio de coleta para o bico de aço inox DG, nos diferentes níveis de desgaste.

27 Estimativas dos ângulos médios dos bicos de três repetições para cada nivel de desgaste e coeficiente de variação, ângulo nominal e desvio médio dos bicos. 


\section{LISTA DE ABREVIATURAS E SÍMBOLOS}

\begin{tabular}{|c|c|}
\hline$\mu \mathrm{m}$ & - micrometro \\
\hline${ }^{\circ} \mathrm{C}$ & - graus Celsius \\
\hline açoi. & - aço inox \\
\hline$A D I$ & - "Alumina Drift ISO" \\
\hline cer & - cerâmica \\
\hline c.v. & - cavalo vapor \\
\hline $\mathrm{CV}$ & - coeficiente de variação \\
\hline $\mathrm{DG}$ & - "Drift Guard" \\
\hline $\mathrm{g}$ & - grama \\
\hline $\mathrm{g} / 1$ & - grama por litro \\
\hline kem & - kematal \\
\hline $\mathrm{kgf} / \mathrm{cm}^{2}$ & - quilograma força por centímetro quadrado \\
\hline $\mathrm{kPa}$ & - quilo Pascal \\
\hline $1 / \min$ & - litro por minuto \\
\hline $\mathrm{lb} / \mathrm{pol}^{2}$ & - libra por polegada quadrada \\
\hline LD & - "Low Drift" \\
\hline $\mathrm{m} / \mathrm{s}$ & - metro por segundo \\
\hline $\min$ & - minuto \\
\hline psi & - "Pounder Square inch" \\
\hline s.d. & - sem data \\
\hline UF & - "Universal Fan" \\
\hline XR & - "Extra Range" \\
\hline
\end{tabular}




\title{
ESTUDO COMPARATIVO ENTRE ABRASIVOS PARA TESTE DE DESGASTE ACELERADO DE BICOS PULVERIZADORES
}

\author{
Autor: LUIZ ATILIO PADOVAN \\ Orientador: Prof. Dr. TOMAZ CAETANO CANNAVAM RIPOLI
}

\section{RESUMO}

A predição da vida útil de bicos pulverizadores é normalmente realizada através de ensaios laboratoriais, envolvendo o uso de uma calda abrasiva que acelera o processo de desgaste. Neste estudo foram selecionados e testados, nove produtos abrasivos, com o objetivo de avaliar suas atuações no teste de desgaste acelerado para seis diferentes tipos de bico de jato plano, analisando o efeito do desgaste sobre as características funcionais dos bicos.

Foram construidos dois equipamentos, sendo um para coleta da vazão e outro para promover o desgaste dos bicos. Utilizou-se também uma mesa de canaletas e um projetor de perfil, além dos aparelhos comuns para as medições. A metodologia utilizada seguiu a Norma NBR 13769 (1997).

Numa primeira etapa, denominada de pré-teste, foi estudado o comportamento do aumento porcentual da vazão, de bicos de baixa deriva e de uso ampliado (110 03), sendo confeccionados em cerâmica, kematal e aço inox, quando sob a ação dos diversos abrasivos. Os valores desse aumento foram analisados, tanto para cada abrasivo nos diferentes bicos, quanto para cada bico nos diferentes abrasivos. 
Efetuou-se também, uma comparação relativa entre os aumentos porcentuais da vazão dos bicos, para cada abrasivo estudado.

$\mathrm{Na}$ Segunda etapa, denominada de teste final, utilizou-se apenas um abrasivo, avaliando as características funcionais dos bicos em função dos níveis de desgaste em até $50 \%$. Foram avaliados os tempos para alcançar determinados niveis de desgaste, as medidas dos diâmetros da elipse, o perfil de distribuição, e o ângulo do jato.

As análises e discussões dos resultados obtidos possibilitaram concluir que: os equipamentos construídos com finalidade específica para este trabalho, mostraram-se adequados para o estudo; não houve um único produto abrasivo que fosse ideal para determinação do desgaste acelerado dos diversos tipos e materiais de confeç̧ão dos bicos; os bicos de baixa deriva apresentaram maior resistência ao desgaste em relação aos de uso ampliado, confeccionados do mesmo material; os resultados do perfil de distribuição, do ângulo do jato e das medidas dos diâmetros da elipse, mostraram que, o desgaste ocorreu no sentido do menor eixo da elipse, provocando diminuição da faixa de deposição, diminuição do ângulo e conseqüente concentração de líquido no centro do perfil; um aumento de até $10 \%$ da vazão dos bicos confeccionados nos diferentes materiais, não provocou grande diferença no $\mathrm{CV}$ da uniformidade da distribuição, ficando este com valor abaixo de $12,22 \%$. 


\title{
A COMPARATIVE STUDY AMONG ABRASIVES FOR ACCELERATED WEAR RATE TESTING OF SPRAYER NOZZLES
}

\author{
Author: LUIZ ATILIO PADOVAN \\ Adviser: Prof. Dr. TOMAZ CAETANO CANNAVAM RIPOLI
}

\section{SUMMARY}

The prediction of the wear life of sprayer nozzles is normally done through laboratory tests involving the use of an abrasive solution that accelerates the wear process. In this study nine abrasive products were chosen and tested for the purpose of evaluating their performance in the accelerated wear test for six different types of flat fan nozzles, and also analyzing the effect of the wear on the functional characteristics of the nozzles.

Two kinds of equipments were built, one for flow rate collection and other to cause the wear of the nozzles. Also, a distribution bench and a profile projector were used, along with the normal equipment for measuring. The methodology used followed the NBR 13769 (1997) standard.

In the first phase, called the pre-test, low drift and universal fan nozzles of ceramic, kematal and stainless steel were used. The behavior of the percentage of the increase of the flow rate of these low drift and universal fan nozzle tips (110 03), was studied under the efffect of different abrasives. The values of these increases were analyzed, for each abrasive in the different nozzles as well as for each nozzle with the 
different abrasives. A relative comparison was also made among the percentages of increase of the flow rate for each abrasive studied.

In the second phase, called the final test, only one abrasive was used in evaluating the functional characteristics of the nozzle in relation to wear levels of up to $50 \%$. The time necesary to reach certain levels of wear, the measurements of the diameters of the elliptical orifice, the spray patterns and the spray angles were evaluated

The analyses and discussion of the results obtained made it possible to conclude that the equipment made for the specific purpose of this project was adequate for the study. There was not just one abrasive product that was ideal for determining the accelerated wear of the diverse types and materials the nozzle were made of. The low drift nozzles showed greater resistance to wear in relation to the universal fan nozzle made of the same material. The results of the spray distribution, the spray angle and the diameters of the elliptical orifice measurements showed that the wear occured in the direction of the smallest axis of the ellipse, causing a decrease of the spray deposition, decrease of the angle and consequent concentration of liquid in the center of the spray pattern. An increase of up to $10 \%$ on the flow rate of the nozzles made of different materials did not cause a great difference in the CV of the uniformity of the distribution; the amount being less than $12,22 \%$. 


\section{INTRODUÇÃO}

O elevado custo do controle fitossanitário, a necessidade de diminuir o nivel de residuos sobre os produtos agrícolas e a contaminação do meio ambiente, são aspectos prioritários na moderna agricultura e exigem uma otimização da utilização e distribuição dos agroquímicos.

Para que haja um aumento na eficiência das operações de aplicação de produtos fitossanitários deve ocorrer, necessariamente, uma melhoria dos componentes das máquinas aplicadoras, tais como, os pulverizadores.

Nos pulverizadores hidráulicos, o bico pulverizador $^{1}$ é o elemento que mais influi na qualidade do serviço. O bico é o órgão encarregado pela divisão do líquido em pequenas gotas, assegurando um bom recobrimento da superficie a ser tratada, proporcionando gotas de dimensões definidas e um número de gotas por unidade de superficie de acordo com o tratamento a realizar

Mesmo sendo o bico pulverizador o elemento fundamental, na distribuição de agroquimicos, segundo Reed \& Ferrazza (1984), existe suficiente evidência que ele também é o componente que menos recebe atenção e controle durante a vida útil do equipamento.

A tendência atual de se empregar pulverizações a volume e pressões mais reduzidas torna a seleção dos bicos pulverizadores bastante crítica. Com isto, a

\footnotetext{
'Adota-se como "bico pulverizador", referindo-se à "ponta do bico", e na maioria dos casos, designado apenas por "bico".
} 
uniformidade de distribuição do produto fitossanitário sobre o alvo constitui uma condição essencial para alcançar bons resultados.

Sartori (1975), comenta que aplicações com irregularidade na distribuição e consequente deposição irregular (pontos com aplicação insuficientes e pontos com excesso de produto), acarreta a necessidade de se usar um alto volume de aplicação de modo a prover o volume de defensivo suficiente nos pontos de baixa deposição.

As causas que provocam a desuniformidade da distribuição e consequente irregularidade na deposição do produto fitossanitário sobre o alvo são numerosas. Entre elas estão: variação da velocidade de deslocamento, variação da pressão de pulverização, ausència de paralelismo entre a barra de pulverização e o alvo (solo ou planta), oscilação horizontal da barra de pulverização, deriva, evaporação, etc.

O processo de desgaste a que são submetidos os bicos pulverizadores, pela ação corrosiva e abrasiva do produto fitossanitário, constitui-se também em um grande fator de irregularidade da distribuição

O desgaste do bico pulverizador traz mudanças significativas tanto na qualidade da distribuição como também na quantidade do produto distribuído pelo bico pulverizador (Zhu et al., 1995).

Os efeitos desse desgaste são detectados através do conjunto das caracteristicas funcionais dos bicos que fundamentalmente são: a vazão, o ângulo de pulverizaçào, o perfil de distribuição ${ }^{2}$ e o tamanho e uniformidade das gotas. Alterações nessas características levam à resultados negativos no trabalho de aplicação do produto fitossanitário (Matthews, 1992).

Barik \& Kuhlman (1990), citam que uma aplicação de 10\% a mais de um defensivo, com duas pulverizações, em uma área de 400 hectares, pode representar uma perda de US\$2.000,00 à US\$10.000,00, considerando-se o custo do produto na ordem de US\$ 25,00 à US\$ 125,00 por hectare, sem se levar em conta os danos potenciais à própria cultura.

2 Termo definido pela Norma NBR - 12936 (1993). 
São muitos os fatores que no campo, provocam o desgaste do orificio dos bicos, entre eles: o tipo e formulação do defensivo, tamanho das partículas, concentração da formulação. filtragem do sistema de pulverização, pressão de trabalho, água utilizada, etc.

O bico de pulverização é a peça que mais rapidamente se desgasta no pulverizador, levando a prejuizos econômicos e ambientais. A maioria dos fabricantes de bicos de pulverização recomendam a substituição desse componente, quando o aumento da vazão exceder a 10\% da original ( Hard International, 1996; Spraying Systems Co. 1994 e Albuz Ceramiques, 1991).

Este aumento de vazão pode ser facilmente corrigido na calibração do pulverizador, diminuindo-se a pressão do sistema, o que, em termos quantitativos, estaria resolvido. Entretanto, a variação do perfil de distribuição e a alteração do tamanho de gotas que ocorrem com o aumento da vazão, é que, segundo os fabricantes. justificam a reposição do bico. A vazão é utilizada como primeiro paràmetro para reposição, porque é a variável que o usuário pode obter mais facilmente.

Os bicos de pulverização são fabricados de diversos materiais, sendo que, os mais comuns, são: latão, aço inox, aço inox endurecido, polimeros e cerâmica Bicos construídos de diferentes materiais, possuem diferentes características de desgaste, em função do grau de dureza do material de origem.

A predição da vida útil dos bicos de pulverização é normalmente realizada através de ensaios laboratoriais, onde são descartadas algumas variáveis que existiriam sob condições de campo. Segundo Reed \& Ferrazza (1984), existem dois tipos básicos de testes utilizados para a determinação da vida útil dos bicos: acelerados e não-acelerados.

O teste não-acelerado é conduzido simulando-se as reais condições da aplicação no campo. Utiliza-se o defensivo sem ingrediente ativo, na pressão comumente recomendada pelo fabricante do bico pulverizador.

$\mathrm{O}$ uso do defensivo em testes de desgaste de bicos, além das restrições de tempo, (Reichard et al., 1990) tem como desvantagem a possibilidade de ocorrer variações do produto específico pois, normalmente os fabricantes de defensivos fazem 
pequenas alterações na formulação ou no material usado como veículo do princípio ativo. o que traz efeito na abrasividade do liquido e consequentemente, variação nos resultados

O teste acelerado é o mais utilizado e envolve o uso de uma calda abrasiva que visa acelerar o processo de desgaste fornecendo resultados rápidos, com menor utilização de mão-de-obra e com vantagem de ser comparativo com outros testes.

Algumas normas estabelecem as caracteristicas fisicas e químicas dos abrasivos, bem como a concentração a ser utilizada nos testes de desgaste. Todavia, apesar de existirem abrasivos normalizados, a bibliografia a respeito de desgaste do bicos de pulverização apresenta consideráveis diferenças entre os resultados das pesquisas. Reed \& Ferrazza (1984), fazem a seguinte declaração: "Infelizmente, quando comparado dados de varias pesquisas, existe uma extrema variabilidade nos resultados."

Os mesmos autores citam os 4 fatores que influenciam no desgaste de um bico de pulverização: 1) forma e tamanho do orificio, 2) pressão de trabalho, 3) material do bico e 4) abrasividade da calda.

Quanto à abrasividade da calda, existem muitos trabalhos, citando fatores que contribuem para a variabilidade dos resultados dos testes: 1) tipo e fonte do abrasivo, 2) tamanho das partículas sólidas (peneira), 3) distribuição do tamanho das particulas sólidas. 4) formato das partículas sólidas, 5) concentração do abrasivo, 6) tempo de uso da calda 7) metodologia utilizada, entre outras (Reed \& Ferrazza, 1984: Barik \& Kuhlman, 1990; Reichard et al., 1990 e Reichard et al., 1991).

Ozkan et al. (1991), argumentam que a maior razão para a ampla diferença dos resultados das pesquisas sobre desgaste de bicos é devido a grande variação do material abrasivo e a concentração desses materiais utilizados nos testes de desgaste.

Por toda problemática exposta, este estudo foi conduzido com objetivo de avaliar alguns materiais abrasivos, comparando-os com os abrasivos normalizados, procurando estabelecer características físicas e de aplicação dos abrasivos para realização de testes acelerados com os vários materiais de fabricação dos bicos, visto que alguns abrasivos normalizados não são facilmente encontrados no mercado nacional. 
Pretende-se ainda que este trabalho sirva como material de análise, para uma possível revisão da norma da ABNT- NBR 13769 - 'Bico de pulverização agrícola - Métodos de ensaio" de janeiro de 1997, no que se refere à indicação do material abrasivo.

Este estudo também teve como objetivo, avaliar o efeito do desgaste nas características funcionais do bico: vazão, perfil de distribuição, ângulo do jato e a uniformidade da distribuição do bico quando associado em barra. 


\section{REVISÃo BIBLIOGRÁFICA}

Com a finalidade de melhor apresentação dos parâmetros envolvidos no trabalho. a revisão bibliografica está dividida nas seguintes partes. 1) Estudo do desgaste de bicos, 2) Estudo da uniformidade da distribuição 3) Abrasivos utilizados em testes de desgaste e 4) Abrasivos normalizados.

\subsection{Estudo do desgaste de bicos}

A dificuldade de comparação entre testes de desgaste de bicos de pulverização, devido às variações das condições em que foram realizados, foi estudada por Reed \& Ferrazza (1984), com base em inúmeros trabalhos encontrados na bibliografia. Os resultados foram analisados e expressos através de um valor de "desgaste relativo", definido pela relação entre o tempo de desgaste e o tipo de material do bico pulverizador considerando o latão como material de referência, tendo este recebido o valor 1. A maior diferença encontrada foi, quando comparou-se o desgaste relativo entre bicos de jato plano, confeccionados em latão e aço inox, de testes realizados por 5 diferentes pesquisadores. O desgaste relativo do aço inox variou de zero até 19 vezes em relação ao latão. Outra comparação revelou a influência da pressão de pulverização sobre o desgaste relativo onde para um mesmo tipo de bico, porém de materiais diferentes 
(latão e aço inox) operando a diferentes pressões, ocorreram grandes diferenças no desgaste relativo: a uma pressão de $138 \mathrm{kPa} \quad\left(\begin{array}{lllll}20 & \mathrm{psi}\end{array}\right) \quad \mathrm{o}$ desgaste relativo foi 9,5 , enquanto que com pressão de $414 \mathrm{kPa}$ (60 psi) o desgaste relativo foi 4,0. Em outra pesquisa citada pelos autores, efetuada pela Spraying Systems Co., 1984, foi comparado o efeito da pressão no desgaste de bicos de jato plano confeccionados em latão. Resultados obtidos revelaram que o tempo para alcançar um determinado nivel de desgaste, foi cinco vezes maior quando se utilizou pressão de $138 \mathrm{kPa}(20 \mathrm{psi})$, em relação ao tempo, utilizando a pressão de $414 \mathrm{kPa}$ (60 psi).

Bode et al. (1984), realizaram testes de desgaste acelerado, comparando bicos confeccionados em náilon, latão e aço inox, com 2 vazões diferentes $(0,8$ e 2,3 V/min), O abrasivo utilizado foi silica hidratada na concentração de $20 \mathrm{~g} / 1$ de água, os intervalos de medições foram progressivos de 0,5 à 16 horas e ficando a pressão mantida à $276 \mathrm{kPa}$ (40 psi). Os resultados mostraram que todos os bicos tiveram maior variação de vazão nas primeiras horas de trabalho; a ordem de resistência ao desgaste foi: aço inox, latão e náilon, e que bicos de menor vazão se desgastam mais rapidamente. Este último resultado também foi obtido por Pirard et al. (1989); Reichard et al. (1991) e Ozkan et al. (1992c)

De acordo com o catálogo de produtos da Hard International (1995), o bico de pulverização precisa ser trocado depois de um certo periodo de serviço, devido aos efeitos da abrasão e corrosão, causados por muitos fatores tais como: tipo e formulação do defensivo, tamanho de partículas do defensivo, sistema de filtragem, concentração da formulação e a pressão de trabalho. Em testes de desgaste de bicos não acelerados os fatores como: tipo de material abrasivo, tamanho e formato das partículas e formação de cristais em suspensão do defensivo, que são reais nas condições de campo, causam uma grande distorção no resultado impossibilitando a comparação destes e dificultando a predição da vida útil dos bicos. Para eliminar estas variáveis, o grupo de tecnologia de aplicação da empresa, realizou testes de desgaste acelerado utilizando várias soluções com diferentes materiais abrasivos e os resultados foram avaliados de forma relativa, isto é, o bico de latão foi tomado como material básico e sua vida útil, baseada 
em $10 \%$ do aumento da vazão ficou representado pelo valor 1 . Foram utilizados bicos de jato plano comum, com vazão de $0,91 \mathrm{l} / \mathrm{min}$ operando à pressão de $300 \mathrm{kPa}$, que apresentaram o seguinte resultado

\begin{tabular}{lcccc}
\hline Material abrasivo & Concentração & \multicolumn{3}{c}{ Material do bico } \\
\hline Hi-Sil 233 & g/ & Latão & Aço inox & Plástico \\
Oxido de aluminio & 20 & 1 & 0,8 & 1,6 \\
Corindom & 20 & 1 & 1,3 & 17 \\
Caulim & 20 & 1 & 2,0 & 22 \\
Óxido de cloreto & 60 & 1 & 4,2 & 25 \\
\hline
\end{tabular}

Novak \& Cavaletto (1988), realizaram testes de desgaste não acelerados em bicos de jato plano, utilizando um herbicida, para simulação de situações reais. Utilizou-se uma formulação de Atrazina, pó molhável AAtrex $80 \mathrm{~W}$ sem ingrediente ativo, fabricado por Ciba-Geigy, na concentração de $37 \mathrm{~g} / 1$ (3 libras para 10 galões de água) e esta calda pulverizada à uma pressão de $276 \mathrm{kPa}$ (40 psi) sendo trocada a cada 50 horas. Os bicos testados variaram em ângulo de pulverização, fabricante, material de fabricação, com 3 exemplares cada tipo, os quais, foram analisados através da variação da vazão e do padrão de distribuição, sendo este comparado utilizando-se o coeficiente de variação (CV), baseado no espaçamento entre bicos de $50 \mathrm{~cm}$ e coletado a $36 \mathrm{~cm}$ de altura, durante um minuto, em canaletas com largura de $2,54 \mathrm{~cm}$ (uma polegada). O perfil de distribuição e a vazão foram medidos nos intervalos de $1,25,50,100,150,200$ e 250 horas, sendo o equipamento e procedimento do teste, de acordo com a Norma ASTM Standard E 641-85. Algumas conclusões efetuadas pelos autores foram: bicos com ângulos de $110^{\circ}$ desgastam mais rápido que bicos com ângulos de $80^{\circ}$; não houve diferença significativa no padrão de distribuição para os bicos desgastados, apresentando um CV entre 10 a $15 \%$ para a maioria dos bicos testados e que a relação da vida útil em 
função do material do bico, (com vida útil igual a 10\% de aumento da vazão ) teve os seguintes tempos, sendo que os valores acima de 250 horas são estimados:

\begin{tabular}{ll}
\hline - latão................ & 100 horas \\
- náilon.............. & 200 horas \\
- aço inox.......... & 400 horas \\
- kematal............ & 400 horas \\
- cerâmica............ indefinido (mais de 400 horas)
\end{tabular}

Testes não acelerados semelhantes, foram efetuados pela Spraying Systems Co. e descritos por Reed \& Ferrazza (1984), que também utilizaram a atrazina para comparar os diferentes materiais de bicos de jato plano: latão, aço inox, aço inox endurecido e um material experimental chamado alumax (óxido de alumínio). $\mathrm{O}$ objetivo do trabalho foi de simular em laboratório, as condições de campo, determinando a vida útil dos bicos confeccionados com diferentes materiais. A concentração do AAtrex $80 \mathrm{~W}$ foi de $33 \mathrm{~g} / 1$ (4 libras por galão americano) operando a $276 \mathrm{kPa}$ (40 psi). A calda foi trocada a cada 50 horas e o teste parou com 513 horas com os seguintes resultados em horas para alcançar $10 \%$ de aumento na vazão:

\begin{tabular}{ll}
\hline Tipo de Bico & Duração do teste \\
\hline 8003 - latão & 15 horas \\
8003 - aço inox & 45 horas \\
8003 - aço inox endurecido & 513 horas \\
8003 - alumax. & indefinido \\
\hline
\end{tabular}

Com 513 horas de testes os bicos de alumax tiveram uma alteração média de $3,1 \%$ na vazão original. Da avaliação do perfil de distribuição, verificou-se que o desgaste provocou concentração do produto no centro do leque. A maior restrição para 
este teste, segundo o autor, foi o seu longo período de duração que envolveu 513 horas de pulverização e um total acima de 1000 horas-homem para coleta dos dados.

Bengisson (1995), na Suiça, verificou o desgaste de bicos utilizados em pulverizadores de barra, em situação prática de campo, medindo antes e depois de cada safra. a vazão. perfil de distribuição, e tamanho de gota de cada bico. Foram testados bicos confeccionados em plástico, latão, aço inox e cerâmica, com duas repetições, equipando 36 pulverizadores utilizados em diferentes culturas. O perfil de distribuição foi avaliado através do coeficiente de determinação $\left(\mathrm{r}^{2}\right)$, e os resultados mostraram que a durabilidade foi maior na ceràmica e menor no latão. Segundo o autor, nenhuma relação foi encontrada entre a variação da vazão, perfil de distribuição e tamanho de gota

Reichard et al. (1991), criaram uma sequência de procedimento para teste de desgaste acelerado de bicos de pulverização em 1990, a qual em 1991, serviu de base para a Norma ASAE Standard: ASAE S471 "Procedure for measuring sprayer nozzle wear rate", e reafirmada em dezembro de 1995. Segundo os autores, são três os fatores que influenciam no desgaste das partículas do abrasivo: vazão total dos bicos, volume da mistura e tempo de uso da mistura, que podem ser expressos pela equação:

$$
\mathrm{T}=\mathrm{K} \cdot \mathrm{V} / \mathrm{Q}
$$

onde: $\mathrm{T}=$ intervalo de troca da mistura (horas); $\mathrm{V}=$ volume da mistura (litros); $\mathrm{Q}=$ vazão total dos bicos (litros/hora) e $\mathrm{K}=$ constante que indica o número de vezes que as partículas do abrasivo devem circular durante o tempo $T$. Os autores analisaram dois tipos de caulim e determinaram experimentalmente para um deles, o valor da constante $\mathrm{K}=$ 300 , ficando a equação $T=300 \mathrm{~V} / \mathrm{Q}$, para este material especifico. Nos testes desenvolvidos pelos autores foram utilizados bicos de jato plano de latão, plástico, aço inox e náilon com vazões nominais de 0,$76 ; 1,5 ; 2,3 ; 3,0 \mathrm{~V}$ min a uma pressão constante de $276 \mathrm{kPa}$ (40 psi). Dentre várias relações que os autores fizeram com os resultados, citam-se algumas: o desgaste do bico pulverizador é afetado pela variação da vazão para um mesmo material, ou seja, bicos de maior vazão sofrem menos desgaste; o desgaste relativo dos bicos em função do material é variável com a vazão nominal dos mesmos; 
aumento da porcentagem da vazão para os bicos de latão, aço inox e náilon varia aproximadamente, com a raiz quadrada do tempo de uso.

Segundo Ozkan et al. (1991), a recomendação para a troca de bicos tem que ser feita através da avaliação do efeito do desgaste sobre a vazão, perfil de distribuição e tamanho de gotas.

$\mathrm{Na}$ maioria das pesquisas com desgastes de bicos, analisa-se a alteração na vazão dos bicos (Corrèa \& Lorena Neto, 1976; Menzies et al., 1976; Reed \& Ferrazza. 1984: Barik \& Kuhlman, 1990; Reichard et al., 1991; Choe et al., 1993; Albuz Ceramiques, s.d.; Bogliani et al., 1994; Zhu et al., 1995). Poucos estudos analisaram também o padrão de distribuição (Sanders, 1981; Friesen, 1984; Pirard et al., 1989; Ozkan et al., 1991; Gandolfo, 1995) e raríssimos estudos analisaram o efeito do desgaste do bico no tamanho de gotas (Ozkan et al., 1992b; Balsari \& Tamagnone, 1995)

Ozkan et al. (1992b), concluíram que o tamanho de gotas é ligeiramente maior para bicos desgastados em $10 \%$ da vazão nominal, em relação ao seu similar novo; que a distribuição do tamanho de gotas para bicos novos de mesma capacidade, porém de diferentes materiais, é aproximadamente a mesma e que o tamanho de gotas aumenta linearmente em relação ao aumento da vazão nominal do bico, tanto em bicos novos como desgastados. Ozkan et al. (1992c), citam que geralmente existe pouca diferença na distribuição do tamanho de gotas entre bicos novos e desgastados.

Conclusão semelhante teve Marques et al. (1988), na Espanha, que analisaram a formação de gotas produzidas por bicos de jato plano de $80^{\circ}$, depois de ter sido utilizadas em condições reais de campo, até alcançar um desgaste quantificado por um aumento de $11 \%$ da vazão nominal, comparado a um bico novo idêntico, verificando que não houve diferenças significativas entre eles, sendo admissível o seu emprego agricola até alcançar um desgaste maior.

Vários pesquisadores são concordantes em concluir que um aumento de até $10 \%$ da vazão nominal de bicos confeccionados em diferentes materiais, não provoca diferença significativa, tanto no $\mathrm{CV}$ da uniformidade de distribuição ao longo da barra, 
como na distribuição do tamanho de gotas. (Sintorn, 1982; Marques et al.,1988; Novak \& Cavaletto, 1988; Friesen, 1988; Ozkan et al,, 1992b; Ozkan et al., 1992c; Rice. 1993)

Já Barrufet et al. (1989), obtiveram o CV da distribuição para bicos desgastados em $10 \%$ de aumento da vazão, de 42,3 e $60 \%$ para os bicos Albuz APG 110 laranja (ceràmica) e Hard $+110-20$ (plástico), respectivamente. O espaçamento entre bicos, na simulação. foi de $50 \mathrm{~cm}$ e a calda foi coletada na altura de $60 \mathrm{~cm}$. Os autores recomendam que estes bicos não devem ser utilizados após 5\% de aumento da vazão, mesmo sabendo-se que suas caracteristicas iniciais de distribuição foram excelentes com $\mathrm{CV}$ de 4.4 e $2.6 \%$ respectivamente. Esta recomendação dos autores confronta com a tolerància do controle de qualidade do fabricante do bico, que aceita uma variação de \pm $5 \%$ em relação a razão nominal (Albuz Ceramiques, s.d.) e a tolerância de $\pm 4 \%$ estipulada pela Organização Mundial da Saúde - OMS (1976).

Ozkan et al. (1991), sugerem que futuras pesquisas sejam feitas, investigando o efeito do desgaste na mudança do padrão de distribuição e no tamanho de gotas, para niveis de desgaste de 10,20,30,40 e 50\% (aumento da vazão original), a fim de estabelecer quando estes paràmetros se tornam intoleráveis e quando os bicos devem ser trocados.

O maior indicador de desgaste de um bico pulverizador é o aumento da vazão (Rice, 1993). A maioria dos fabricantes recomendam que um bico é considerado gasto e deve ser substituido, quando a sua vazão excede a vazão de um bico novo em 10\% (Hard International, 1995; Spraying Systems Co., 1994; Albuz Ceramiques, 1991; Honda $\left.{ }^{3}, 1997\right)$ A ASAE Standards: ASAE EP367 (1995, p.210) indica a substituição do bico quando este estiver com vazão de $\pm 10 \%$ da média dos outros bicos em uso.

\footnotetext{
${ }^{3}$ HONDA. A.H. (Máquinas Agricolas Jacto S.A.) Comunicação pessoal, 1997.
} 


\subsection{Estudo da uniformidade da distribuição}

Balastreire (1970), observa que a maioria dos autores são concordantes em considerar a uniformidade da distribuição do defensivo como o mais importante fator a ser levado em conta na sua aplicação através de bicos. Com isto, os estudos sobre bicos que levam em conta a distribuição volumétrica do líquido ao longo da faixa de deposição se tomam fundamentais, sendo os demais fatores baseados em tamanho de gotas, apenas um complemento para o primeiro

Bode (1970), citado por Balastreire (1970), em correspondência pessoal, reconheceu que a melhor maneira de se expressar a uniformidade de distribuição do líquido pulverizado, é o paràmetro estatístico conhecido universalmente por coeficiente de variação $(\mathrm{CV})$.

Quanto menor o coeficiente de variação, mais uniforme é a distribuição. Um CV de $0 \%$ seria um mesmo volume em todos os tubos da mesa de canaletas (linha reta), isto é. uma perfeita distribuição ( TeeJet Journal, 1990).

A distribuição quantitativa do líquido dentro do jato emitido, que é chamada de perfil de distribuição (Christofoletti, 1995), é de importância fundamental no desempenho dos bicos de pulverização. A distribuição da calda sobre a área tratada deve ser a mais perfeita possivel. A variação do produto ao longo de uma área tratada pode ser avaliada pelas quantidades em pontos específicos e a média obtida é quantificada pelo coeficiente de variação $(\mathrm{CV})$, que passa a ter limites cada vez mais baixos, tendo em vista a necessidade de aplicações mais precisas, evitando-se falhas e sobredosagens que resultam em aumento de resíduos no solo, nas plantas, nas águas subterrâneas e no meio ambiente. Alguns fatores que contribuem para o aumento do coeficiente de variação são: bicos de baixa qualidade, bicos desgastados e danificados, bicos mal instalados (altura e espaçamento) na barra, variações de velocidade e pressão de trabalho, flexões acentuadas (verticais e horizontais) da barra em relação ao alvo, etc, fatores também citados por Perecin et al. (1994). 
Ozkan et al. (1992a) realizaram testes de desgaste, analisando o perfil de distribuição, atraves do coeficiente de variação. Neste estudo utilizou-se o caulim na concentração de $60 \mathrm{~g} / 1$ de agua para desgastar bicos de jato plano, com ângulo de $80^{\circ}$, confeccionados em latão, aço inox, aço inox endurecido, náilon e plástico com quatro diferentes vazões nominais e très exemplares de cada tipo. Os bicos de mesma vazão foram testados simultaneamente ( 15 bicos), na pressão de $276 \mathrm{kPa}$. O teste foi encerrado quando a vazão atingiu $10 \%$ de aumento para os bicos de aço inox. $\mathrm{Na}$ análise do $\mathrm{CV}$, fixou-se a altura de $48 \mathrm{~cm}$ e espaçamento entre bicos de $51 \mathrm{~cm}$, medidas estas indicadas pelo fabricante. obtendo as seguintes conclusões: em 11 das 19 (58\%) comparações entre bicos novos e desgastados, os bicos desgastados apresentaram distribuições com CV menor que os bicos novos do mesmo tipo. Outro dado obtido foi que todos bicos, novos e desgastados tiveram $\mathrm{CV}$ menor que $15 \%$ e $90 \%$ dos bicos desgastados tiveram distribuições com CV menor que 10\%, que segundo Azime et al. (1985), CV abaixo de $10 \%$ é aceito como variação normal na distribuição e Friesen, (1988) cita que CV menor ou igual a $10 \%$ é bom, entre 10 e $15 \%$ é aceitável e acima de $15 \%$ é inaceitável, o que confirma a citação do autor anterior

Zhu at al. (1995), verificaram que o desgaste do orificio de um bico de jato plano, no sentido do diâmetro maior da elipse, é menor que o desgaste que ocorre no sentido do diâmetro menor, isto é, com o desgaste, a elipse tem tendência de tomar um formato arredondado, o que indicou que o desgaste do bico pulverizador não implicou em mudança na largura do perfil de distribuição, mas sim um aumento da vazão no centro da curva de distribuição, com alteração do coeficiente de variação da distribuição. Isto concorda com os resultados de Ozkan et al. (1992c), pois concluíram que não houve alteração na largura da curva de distribuição, porém ocorreu concentração de líquido no centro da mesma e Barrufet et al. (1989), onde explicam que a forma elíptica inicial do orificio dos bicos vai se transformando, paulatinamente, em circular, processo que explica a diminuição do ângulo de jato, obtido pelos autores.

Balsari \& Tamagnone (1993), testaram alguns parâmetros de 26 bicos novos de jato cônico, jato plano e jato defletido, fabricados de diferentes materiais, pelas 
principais empresas do mercado italiano. A vazão, o ângulo do jato e o perfil de distribuição foram testados e comparados com os dados do catálogo do fabricante. Com respeito a vazão, a pior série apresentou um $\mathrm{CV}$ de $8 \%$ com a diferença máxima de $13 \%$. A maioria dos perfis de distribuição da mesma série, apresentaram coeficiente de variação superior à $40 \%$, o que segundo o autor, afetaria a regularidade da distribuição quando associados em barra de aplicação

$\mathrm{Na}$ segunda parte de seu trabalho, Balsari \& Tamagnone (1995), analisaram os mesmos parâmetros para os mesmos tipos de bicos, porém com os bicos desgastados em teste de desgaste acelerado utilizando várias caldas abrasivas, que duraram de 3 a 360 horas. A ordem de resistencia ao desgaste dos materiais testados foram: ceràmica > resina sintética $>$ aço inox > latão. Para os bicos de jato plano o aumento da vazão reduziu o ângulo de pulverização e a largura do perfil de distribuição e provocou o aumento do tamanho de gotas.

Sintorn (1982), verificou em teste acelerado entre 10 a 100 horas que bicos de jato cônico quando desgastados, tem maior variação da distribuição, com $\mathrm{CV}$ acima de $30 \%$, quando comparado com bicos de jato plano, para um mesmo nível de desgaste.

Balastreire (1970), estudou a faixa de deposição de 8 tipos de jato plano confeccionados em latão, sob efeito de diferentes pressões e diferentes alturas dos bicos sobre a bandeja coletora. O trabalho foi dividido em 3 fases: os ensaios preliminares com bicos de jato plano comum, os ensaios de bicos projetados para faixa de deposição contínua e os ensaios de bicos associados em barra. A uniformidade do perfil de distribuição produzida por bicos individuais ou associados em barra, foi julgada através do coeficiente de variação (CV) dos dados de vazões, obtidos ao longo de um dado comprimento. $\mathrm{O}$ autor define também, mais dois parâmetros de desempenho funcional dos bicos que são: eficácia de distribuição volumétrica e eficácia de distribuição linear. Segundo o autor, este estudo das associações de bicos em barra, permitiu que um novo método de espaçamento de bicos fosse visualizado, o qual possibilita a obtenção de faixas de deposição, cuja uniformidade é expressa por baixos valores do coeficiente de variação, para as alturas e pressões consideradas. 
Perecin et al. (1994), analisaram os perfis de distribuição obtidos com 10 bicos TwinJet, (TJ60 - 11006) em barra total, variando a altura e o espaçamento entre bicos. O perfil de distribuição de cada bico, em cada altura foi obtido em uma mesa de canaletas com paredes inclinadas de $2,5 \mathrm{~cm}$ de afastamento e o volume pulverizado por cada bico, em cada altura, foi obtido em condições padronizadas: 1 minuto sob pressão de $310 \mathrm{kPa}$ (45 psi). Foram analisados o volume médio dos bicos em cada altura e o coeficiente de variação para cada posição e em cada espaçamento entre bicos. As vazões obtidas em cada bico tiveram a média de $2,351 / \mathrm{min}$, com coeficiente de variação de $2,4 \%$, que segundo os autores mostrou-se um aceitável padrão de uniformidade. Os autores concluiram que. a medida que aumenta o espaçamento entre bicos, piora a uniformidade de aplicação, exigindo a barra cada vez mais alta, o que trará efeitos relacionados com ventos, evaporação, deriva e outros. Para o espaçamento de $50 \mathrm{~cm}$, usual no Brasil, os coeficientes de variação estiveram ao redor de $20 \%$ para alturas entre 20 a $35 \mathrm{~cm}$, mostrando a conveniência de trabalhar em espaçamentos menores, pois segundo Wolf \& Smith (1979) e DeBoer \& Wiens (1983), um coeficiente de variação de 10 a $15 \%$ ou menor, produz uma satisfatória uniformidade.

Sartori (1985), afirma que o volume de defensivo aplicado ao longo da barra deve ser o mais constante possivel, aceitando-se variações de $\pm 15 \%$, e que, esta uniformidade, é dada pelas condições de montagem e de operação: espaçamento entre bicos, altura da barra, ângulo de abertura dos bicos e pressão de trabalho.

Galli et al. (1983), em estudo do perfil de distribuição de bicos hidráulicos disponiveis no mercado brasileiro na época, obteve conclusões sobre a vazão média, onde apenas 2 dos 18 tipos de bicos testados não apresentaram variações consideráveis na vazão observada, em relação a vazão indicada pelo fabricante. Os autores levam em consideração a tolerância de $\pm 4 \%$, estipulada pela Organização Mundial de Saúde OMS (1976).

Já em outro trabalho realizado por Galli \& Arruda (1985), analisaram a distribuição volumétrica de 40 bicos de jato cônico JD 14-2, os quais mostraram pouca variação da vazão entre os exemplares na pressão de $276 \mathrm{kPa}$, com coeficiente de 
variação de $3.7 \%$ e uma diferença média de $-2 \%$ da vazão estipulada pelo fabricante. Entretanto, diferiram consideravelmente com relação ao perfil de distribuição volumétrica, o que, segundo os autores, deve-se a falta de padronização no processo de fabricação ou falhas no controle de qualidade.

Trefan (1984), avaliando o rendimento de bicos individuais, relata que a variação da vazão dos bicos em relação à vazão nominal do fabricante pode ser de $\pm 5 \%$.

Leunda et al. (1990), verificaram o perfil de distribuição de bicos 11002 , 11004 e 11006, variando a altura $(40,60$ e $80 \mathrm{~cm})$ e a pressão $(100,200,300$ e $400 \mathrm{kPa})$. Analisaram a uniformidade de distribuição simulando o bico na barra, nos espaçamentos de 20,30, 40,50 e $70 \mathrm{~cm}$, medindo através do coeficiente de variação. Observaram que para o bico $11002 \mathrm{com}$ altura de $40 \mathrm{~cm}$ e pressão de $400 \mathrm{kPa}$, o coeficiente de variação diminuiu à medida em que se reduziu o espaçamento entre bicos, sendo que espaçado a 50 $\mathrm{cm}$ o coeficiente de variação ficou ao redor de $1,5 \%$. O coeficiente de variação diminuiu tambem, na medida em que a altura de pulverização foi aumentada, utilizando o bico 11006 espaçado a $50 \mathrm{~cm}$, mostrando ainda que, quanto maior a altura, menos o coeficiente de variação é afetado pela variação da pressão. Estes resultados são concordantes com os de Mawner \& Miller (1989), onde explicam que através dos resultados obtidos seria indicado pulverizar com alturas máximas, mas na prática causaria o aumento da deriva e evaporação. Por isso recomendam que é importante manter a barra o mais baixo possivel, tal que não comprometa o aumento do coeficiente de variação da uniformidade de distribuição.

Wang et al. (1995), propuseram um novo modelo para medir a uniformidade da distribuição de bicos e chamaram de grau de desuniformidade (DNU degree of nonuniformity), e explicam que, este modelo, é mais preciso que a medida do coeficiente de variação, pois analisa a intensidade do perfil de distribuição ao longo da faixa. Neste trabalho, os autores investigaram os efeitos da pressão, altura e o tipo de material de confecção do bico, na uniformidade de distribuição. Foram utilizados bicos de jato plano TeeJet XR 11004 (Spraying Systems Co.) confeccionados em latão, aço inox endurecido, polímero, cerâmica e aço inox, com três exemplares de cada material. 
As pressões foram de 138,276 e $414 \mathrm{kPa}(20,40$ e $60 \mathrm{psi})$ e as alturas de $31,38 \mathrm{e} 46 \mathrm{~cm}$ (12, 15 e 18 polegadas). Concluíram que, a altura tem um forte efeito sobre a uniformidade de distribuição, mas a pressão não teve efeito significativo na uniformidade. Com respeito aos tipos de materiais, os bicos não metálicos (cerâmica e plástico) promoveram maior uniformidade da distribuição que os bicos metálicos, ficando os materiais na seguinte ordem: ceràmica, polímero, aço inox endurecido, aço inox e latão.

Resultados concordantes com os citados anteriores, também foram obtidos por Sanders (1981), que verificou a uniformidade da distribuição através do CV, para bicos confeccionados em náilon, latão e aço inox. $\mathrm{O}$ náilon (não metálico) teve $\mathrm{o} \mathrm{CV}$ menor que $10 \%$ enquanto para os demais bicos o CV ficou entre 26 a $93 \%$.

Furlanetti (1995), avaliou os efeitos do tipo e capacidade do bico, espaçamentos, pressões e alturas sobre a vazão e a uniformidade de deposição da pulverização. Foram utilizados 4 tipos de bicos de jato plano: TP, XR, DG e TJ-60 da Spraying Systems Co, sendo cada um dos tipos, de diferentes vazões (8002 e 8004), com 6 exemplares cada tipo (48 bicos). No estudo da vazão, os bicos apresentaram baixos CV nas vazões obtidas com os diferentes exemplares de todos os modelos, sendo o máximo CV igual a 1,86\%. O máximo desvio entre as vazões médias determinadas e as vazões nominais do fabricante foi de 3,9\%. Para o estudo da uniformidade de deposição, foi selecionado um bico entre os seis exemplares e em uma primeira etapa, foi variada a pressão, fixando a altura de coleta em $50 \mathrm{~cm}$ e posteriormente fixou-se a pressão em 276 $\mathrm{kPa}$ e variou a altura de coleta. De posse dos perfis de distribuição individuais, simulouse a constituição de barras variando o espaçamento entre bicos, para determinação do $\mathrm{CV}$ da distribuição. A autora cita o limite do $\mathrm{CV}$, de $7 \%$ indicado pela entidade de pesquisa Biologische Bundesanstalt Fûrland-Und Forstwrts-Chaft Bundesrepublik Deutschland (1988). Concluiu-se que: a) bicos de maior vazão proporcionam deposição mais uniforme; b) aumentos de pressão e altura de trabalho e redução no espaçamento, utilizados de forma isolada ou combinada, proporcionam elevações na uniformidade de distribuição. 


\subsection{Abrasivos utilizados em testes de desgaste}

São vários os materiais abrasivos utilizados nos testes de desgaste acelerado de bicos pulverizadores. Além disso, fatores como o formato, tamanho e distribuição do tamanho das partículas que contribuem na variação do grau de abrasividade do produto, são pouco considerados e descritos pelos pesquisadores (Reed \& Ferrazza, 1984 ).

Bode et al. (1984), utilizaram a sílica hidratada na concentração de $20 \mathrm{~g} / \mathrm{l}$ de água (8 libras para 50 galões), testando os bicos de náilon, latão e aço inox que tiveram em 16 horas de testes, aumentos percentuais na vazão de 55, 44 e $30 \%$, respectivamente.

Corrêa \& Lorena Neto (1976), realizaram teste de desgaste em bicos de jato cônico, utilizando como agente abrasivo o oxicloreto de cobre (Sandoz 50\%) na concentração de $2 \%$, numa pressão de uso corrente para aqueles bicos, $1960 \mathrm{kPa}$ (284 psi). A calda com volume de 100 litros era renovada a cada 20 horas, num total de 250 horas. Foram utilizados 6 tipos de bicos, com os helicóides confeccionados em latão, náilon e aço inox e os discos confeccionados em aço endurecido, aço inox e de carbureto de tungstênio, com 3 exemplares de cada tipo. Foi investigado o efeito do desgaste do bico, na vazão, no ângulo do cone de pulverização e as deformações desse cone. De um modo geral, os maiores aumentos da vazão ocorreram nas primeiras 50 horas de ensaio, o que, segundo os autores, isto se explica devido ao processo de "amaciamento" do bico, isto é, o desaparecimento das bordas de ângulos retos e rebarbas oriundas do processo de fabricação. Outras conclusões citadas pelos autores foram: a) nos bicos cônicos, a peça que apresentou maior desgaste foi o helicóide. b) que o desgaste do orificio dos discos apresentou menor influência nas alterações da vazão. c) os bicos com helicóide de latão apresentaram maior desgaste que os de náilon e aço inox e que o comportamento do náilon foi inferior ao do aço inox. d) os bicos cujas curvas de desgaste são muito inclinadas, isto é , próximas ao eixo das ordenadas, requerem calibragem mais freqüente 
da vazào do pulverizador para acertar a quantidade do defensivo evitando desperdícios de produtos e possiveis prejuizos à cultura e ao meio ambiente.

Corrèa (1988), analisou entre outros parâmetros, o desgaste de bicos de jato plano. Os bicos utilizados no teste foram o bico leque Albuz APG 110R e Micron $110 \mathrm{C} 3$, ambos confeccionados em ceràmica (óxido de alumínio $\mathrm{AL}_{2} \mathrm{O}_{3}$ ), sendo que cada bico foi testado separadamente, inclusive em épocas diferentes. $\mathrm{O}$ abrasivo utilizado em ambos os casos foi a areia de fundição (Shell mold) com granulometria média de $144 \mu \mathrm{m}$, com CV de $21.14 \%$ referente ao tamanho das partículas. A concentração média da areia foi de $1,2 \mathrm{~g} /$ de agua e o material abrasivo trocado a cada 10 horas. No final de 50 horas de ensaio de desgaste, os bicos APG 110R e o bico Micron 110 C3 tiveram um aumento na vazão inicial de 44 e $32 \%$, respectivamente. Esta alteração não foi regular, sendo mais acentuada nas primeiras 5 horas de testes quando o aumento de vazão foi de $24 \%$ para os bicos APG $110 \mathrm{R}$ e $13 \%$ para o bico Micron $110 \mathrm{C} 3$. Com estes dados estima-se que, para um aumento percentual de 10\% sobre a vazão inicial, são necessárias apenas 2,1 horas de ensaio para o bico APG $110 \mathrm{R}$ e 3,8 horas para o bico Micron 110 C3, o que é um tempo muito rápido, mesmo para um teste acelerado, quando comparado com outros testes utilizando outros abrasivos (Reichard et al. e Zhu et al. 1995).

Barrufet et al. (1989), utilizaram também a areia como agente abrasivo, com tamanho de particulas compreendidas entre 100 e $200 \mu \mathrm{m}$, na concentração de $2 \mathrm{~g} / 1$ de água, sendo a calda, substituída a cada 30 horas. Foram testados bicos de jato cônico e jato plano, sendo estes confeccionados em plástico (Hard) e cerâmica (Albuz). Analisaram o aumento da vazão, ângulo do jato, perfil de distribuição e a homogeneidade do tamanho de gotas, em quatro diferentes niveis de desgaste: 0, 5, 10 e 20\%. Para os bicos de jato plano de $110^{\circ}$, o tempo para alcançar $20 \%$, foi de 122 horas para o bico de cerâmica Albuz APG 110 laranja e 40 horas para o bico de plástico Hard 4 110-20, ficando a ceràmica com uma resistência ao desgaste 3 vezes maior que o plástico.

Teste de desgaste acelerado foi realizado pela Micron-Bicos Cerâmicos (s.d.), utilizando como agente abrasivo, $1 \%$ de pó de óxido de alumínio, mesh 325. $\mathrm{O}$ teste teve duração de 5 horas, operando a uma pressão de $690 \mathrm{kPa}$ (100 psi). Foram 
testados os bicos confeccionados em latão, aço inox, plástico e cerâmica. O bico de latão chegou a $50 \%$ de aumento da vazão em 3 horas de teste. O bico de aço inox atingiu $49,2 \%$ de aumento na quinta hora de teste, quando este foi suspenso. O bico de plástico apresentou um decréscimo de, aproximadamente, $-5 \%$ na primeira meia hora, voltando a vazão nominal com uma hora de teste e em seguida aumentando a vazão, chegando na quinta hora com $38 \%$ de aumento da vazão. O bico de cerâmica, praticamente não desgastou, apresentando $3,7 \%$ de aumento da vazão durante o teste.

Testes conduzidos pela Albuz Ceramiques (1991), compararam o desgaste de diferentes materiais de bicos, avaliando o aumento porcentual da vazão. Foram utilizados bicos de aço inox, plástico tipo kematal e alumina (cerâmica), com 5 exemplares de cada tipo, sendo este último do tipo Albuz API 11002 (amarelo) e os demais equivalentes em ângulo e vazão nominal. O teste foi conduzido segundo a Norma Francesa AFNOR NF U 26-110 (1979) que indica o corindon na concentração de 20 g/l de água como material abrasivo. A duração do teste foi de 100 horas, sendo que o bico de aço inox apresentou $40 \%$ de aumento da vazão com 10 horas de testes. O bico de cerâmica apresentou $5 \%$ de aumento da vazão com 100 horas de teste mostrando uma estabilidade no desgaste após 50 horas de teste. O kematal teve decréscimo de vazão atingindo $-5 \%$ nas primeiras 5 horas, voltando à vazão inicial com 10 horas e apresentando $35 \%$ de aumento da vazão com 100 horas de teste.

Esta caracteristica do plástico em decrescer a vazão em função do tempo de uso, para depois então começar a aumentar, também foi verificada por Reichard et al. (1990) e Reichard et al. (1991), que citam não saber o motivo deste efeito, mas que em seus testes não passou de $-2 \%$. Cita ainda que até $10 \%$ de aumento da vazão, alguns bicos de plástico asseguram tempos de uso maiores que de aço inox, mas depois de $10 \%$ sua vazão aumentou em intervalos maiores que do aço inox. Já Matthews \& Thronhill, (1996) explicam que esta característica dos bicos de plástico em decrescer a vazão nas primeiras horas de uso, é devido a absorção de água pelo plástico, o que afeta a vazão pelo fato da mudança do tamanho do orificio. 
Para o desenvolvimento da Norma ASAE Standards: ASAE S471, utilizou-se como abrasivo o caulim, que segundo Reichard et al. (1991), é um material utilizado como veículo do ingrediente ativo nas formulações de defensivos em pó molhável. A concentração utilizada foi de $60 \mathrm{~g} / \mathrm{l}$ de água, que foi utilizada para desgastar bicos de jato plano, confeccionados em latão, aço inox, aço inox endurecido, náilon e plástico, não sendo mencionado o seu uso para bicos de cerâmica.

Choe et al. (1993), estudaram a resistência ao desgaste de dois bicos de jato cônico confeccionados em cerâmica e aço inox, utilizando uma solução de cal viva e água de torneira como agentes abrasivos. Os autores analisaram o aumento porcentual da vazão e a abertura do furo do disco do bico. Utilizando a solução de cal viva em 100 horas obteve-se os seguintes resultados:

\begin{tabular}{lcc}
\hline Material & Diâmetro do furo & Vazão \\
\hline Cerâmica & $3,7 \%$ & $3,5 \%$ \\
Aço Inox & $88,5 \%$ & $109,9 \%$ \\
\hline
\end{tabular}

Nos ensaios com água de torneira, durante 100 horas de testes, não houve diferença significativa no diâmetro do furo do disco e na vazão dos bicos.

Resultados não significativos, também obteve Friesen (1988), conduzindo testes de desgaste não acelerados utilizando água comum da cidade, para desgastar 15 diferentes tipos de bicos de jato plano, variando o fabricante, ângulo do jato e material de confecção (aço inox, náilon e kematal), com 3 exemplares de cada tipo, operando na pressão de $250 \mathrm{kPa}$. A duração do teste foi de 192 horas ( 8 dias), sendo medido a cada 24 horas. Os bicos de aço inox, náilon e kematal tiveram em média um aumento porcentual da vazão de 0,$9 ; 0,8$ e $0 \%$ respectivamente, sendo esta variação aceitável segundo a tolerância de $\pm 4 \%$ estipulada pela Organização Mundial da Saúde - OMS (1976).

Bogliani et al. (1994), analisaram o desgaste de bicos de jato plano, verificando apenas o aumento percentual da vazão, variando os materiais de fabricação que foram : cerâmica, aço inox, kematal, latão e plástico. A duração total do teste foi de 
40 horas com medições parciais a cada 10 horas, a uma pressão de $294 \mathrm{kPa}$. O abrasivo utilizado foi o oxicloreto de cobre, com $20 \%$ em água ( $200 \mathrm{~g} / \mathrm{l})$ e os autores citam que o ensaio segue a Norma Internacional ISO 5682/1-81. As porcentagens de aumento da vazão, em função do material do bico foram as seguintes: cerâmica 1,66\%; aço inox $2,23 \%$, kematal $7,14 \%$; latão $13,60 \%$ e plástico $15,30 \%$.

Zhu et al. (1995), num trabalho para desenvolver um modelo matemático para predição do desgaste de bicos de jato plano com ângulo de $80^{\circ}$, utilizaram como agente abrasivo o caulim com $60 \mathrm{~g} / \mathrm{l}$ de água para desgastar bicos de latão, aço inox, náilon e cerâmica, e o bióxido de silício (Hi-Sil 233) com $20 \mathrm{~g} / \mathrm{l}$ de água usado para desgastar bicos de latão, aço inox e cerâmica. O perfil de distribuição foi medido para très exemplares do bico de latão 8002 , nos niveis $10,20,30,40$ e 50\% de aumento da vazão, posicionando o bico a $50 \mathrm{~cm}$ de altura com pressão de $276 \mathrm{kPa}$. Para elevar a vazão em 10\% de desgaste no bico de cerâmica (80-2, Delavan Co.) utilizando o Hi-Sil 233, foram necessárias 20 horas de testes, enquanto que, utilizando o caulim, 80 horas de testes, elevaram a vazão em apenas $3 \%$ da vazão original.

Gandolfo (1995), realizando um estudo dos efeitos do desgaste sobre a vazão e o perfil de distribuição em bicos de jato plano, utilizou materiais e métodos que obedecem o projeto de Norma ISO 5682 de 1983, a qual determina e especifica o abrasivo para ensaio de desgaste, mas não encontrando o abrasivo, na especificação recomendada pela norma citada no mercado nacional, caracterizou o abrasivo encontrado no mercado local (Argentina). Com o abrasivo caracterizado, testou-se bicos de plástico e aço inox, com sistema anti-deriva formado por núcleos perfurados montados em uma posição anterior à ponta do bico. Outro fator de variação, foi 3 niveis de pressão de pulverização: máxima, mínima e intermediária indicada pelo fabricante; 345, 207 e 276 $\mathrm{kPa}$, respectivamente. Dentre as conclusões apresentadas pelo autor cita-se que as pastilhas de plástico apresentam maior resistência. O tempo de ensaio para alcançar um aumento de $10 \%$ na vazão, em função da variação da pressão de 207,276 e $345 \mathrm{kPa}$, foi de 6,$9 ; 5,5$ e 23,8 minutos para o bico de plástico e 9,$7 ; 10,5$ e 25,2 minutos para o bico de aço inox, respectivamente. Este tempo curtíssimo para elevar a vazão a $10 \%$ da 
original, deveu-se ao coríndon, que é um material altamente abrasivo, principalmente na granulometria que foi utilizado, testando bicos confeccionados em plástico e aço inox, pois são resultados semelhantes aos citados pela Empresa Micron-Bicos Cerâmicos (s.d.).

\subsection{Abrasivos Normalizados}

A Organização Mundial da Saúde - OMS (1976), na convenção de Genebra, sugere um material abrasivo, citando todas as suas propriedades fisicas e químicas para o uso em teste de determinação da abrasão do orificio do bico pulverizador. $\mathrm{Na}$ época foi indicado um pó de silício sintético na concentração de $19,2 \mathrm{~g} / \mathrm{l}$, que foi utilizado por Bode et al. (1984) testando bicos de náilon, latão e aço inox, e atualmente por Zhu et al. (1995) que utilizaram o Hi-Sil 233 (bióxido de silício) para teste de bicos de alta resistência a abrasão (bicos de cerâmica).

As Normas ISO 5682/1 (1981) e UNE 68-055 (1982) citam apenas a concentração do abrasivo $(20 \mathrm{~g} / \mathrm{l})$ não especificando-o, mas exige que nos testes seja feita a caracterização do mesmo, quanto ao nome, tipo e granulometria. A segunda parte da Norma ISO, a ISO 5682/2 (1986), descreve as características fisicas e químicas do oxicloreto de cobre, que deve ser utilizado na concentração de $1 \%$ (10 g/l de água), para teste do agitador da calda no tanque do pulverizador. Este material foi confundido por alguns pesquisadores (Bogliani et al., 1994), que o utilizaram como agente abrasivo em teste de desgaste acelerado de bicos.

Um projeto de Norma ISO 5682 (1983) e uma Norma Francesa já homologada, AFNOR NF U26-110 (1979), indicam o uso do corindon (óxido de alumínio) com $20 \mathrm{~g} / \mathrm{l}$, especificando todas as características de granulometria e constituição química do material. Gandolfo (1995), utilizou o coríndon em seus testes, entretanto, cita que, um inconveniente encontrado, foi a dificuldade de achar o coríndon 
nas dimensões definidas pela Norma, ainda que tenha pesquisado sobre o material tanto no mercado local, como no exterior. Este material também foi utilizado em testes realizados pela Albuz Ceramiques (s.d.), pois citam ter conduzido os ensaios, segundo a Norma AFNOR NF U 26-110 (1979).

A ASTM E641-85 (1991) "Standard Methods for testing Agricultural Hydraulic Spray Nozzles", reaprovada em 1991, indica como material abrasivo, o quartzo, com tamanho uniforme, não estabelecendo as medidas e a concentração a ser utilizada.

A ASAE Standard: ASAE S471 Dec 95 "Procedure for Measuring Sprayer Nozzle Wear Rate", elaborada em 1991, baseada em testes de desgaste com alguns materiais abrasivos para desgastar bicos confeccionados em latão, plástico, aço inox e náilon feito por Reichard et al. (1991), indica o caulim com $60 \mathrm{~g} / 1$ de água, e granulometria com o diâmetro mediano de $4,5 \mu \mathrm{m}$, com retenção máxima de $0,5 \%$ na peneira 325. No trabalho original, que deu origem a Norma, não é citado o uso do caulim para testes com bicos de cerâmica.

A segunda edição da Norma ISO 5682-1 (1997), especifica o material abrasivo a ser utilizado em testes de desgaste acelerado: o óxido de alumínio $\left(\mathrm{Al}_{2} \mathrm{O}_{3}\right)$, na concentração de $20 \mathrm{~g} / 1$ e substituído a cada 50 ciclos. É apresentado na Norma a caracterização fisica e química do material que diferencia do coríndon citado no projeto de Norma ISO 5682 (1983). O seu uso é generalizado para todos os materiais de confeç̧ão de bicos.

A Associação Brasileira de Normas Técnicas - ABNT, através da NBR 13769 (1997), elaborada com base na ISO 5682-1: 1981, pela Comissão de Estudo de Máquinas e Implementos para a Aplicação de Defensivos Agrícolas do CB-04 - Comitê Brasileiro de Máquinas e Equipamentos Mecânicos, recomenda dois abrasivos para teste de desgaste acelerado de bicos de pulverização. Para bicos confeccionados em latão e material plástico, o abrasivo recomendado é o caulim, na concentração de $30 \mathrm{~g} / \mathrm{l}$ e que passe pela peneira de 200 mesh, com retenção máxima de $0,5 \%$ do material. Para bicos de alta resistência a abrasão, o abrasivo recomendado é a areia (quartzo) na concentração 
de $1 \mathrm{~g} / \mathrm{l}$ e com granulometria entre 100 e $150 \mu \mathrm{m}$, com máximo coeficiente de variação do tamanho das partículas de $25 \%$. O material abrasivo deve ser substituido sempre que o volume circulado pelo bico completar 600 litros, de modo a garantir a efetividade da ação do agente abrasivo. A utilização da areia como material abrasivo foi indicado baseando-se em trabalhos realizados por Corrêa (1987) e Corrêa (1988) 


\section{MATERIAL E MÉTODOS}

\subsection{Material}

\subsubsection{Local}

Este trabalho foi realizado nas dependências da Fundação Shunji Nishimura de Tecnologia, localizada no município de Pompéia, S.P., onde foram fabricados os equipamentos, tanque de desgaste e tanque de coleta da vazão, com finalidade específica para este trabalho. A mesa de canaletas e o projetor de perfil, são equipamentos pertencentes ao Setor de Treinamento e Laboratório de Metrologia, respectivamente, da Empresa Máquinas Agrícolas Jacto S.A., localizada no mesmo município.

Os estudos foram desenvolvidos no periodo de janeiro a outubro de 1997 , em condições laboratoriais.

\subsubsection{Equipamentos}

Para realização deste trabalho foram utilizados os seguintes equipamentos:

\subsubsection{Tanque de coleta da vazão}

Este circuito trabalha com água limpa e foi construido para efetuar as leituras de vazão dos bicos em todas as fases do trabalho (Figuras 1 e 2). É composto por 
um sistema hidráulico pulverizador com um tanque de polietileno de forma afunilada, cortado em sua face superior, com capacidade para 150 litros montado em um chassi móvel; uma bomba de pistão de 3 cilindros, acionada por um motor elétrico de 3 c.v. de potência, com vazão de $26 \mathrm{l} / \mathrm{min}$, girando a $500 \mathrm{rpm}$ e câmara compensadora de 0,5 litros. O circuito possui um regulador de pressão do tipo pressão constante, com registro de fecho rápido, retorno livre e manômetro; uma barra de pulverização com 3 portabicos de engate rápido e manômetro de barra. Os manômetros do regulador de pressão e da barra tem exatidão de $2 \%$ da pressão efetiva de trabalho $(276 \mathrm{kPa})$ e foram aferidos no Laboratório de Experimentação e Normalização de Engenharia, da Empresa Máquinas Agrícolas Jacto S./A.. Posicionado a meia altura do tanque esta fixada uma plataforma de madeira, para sustentação da proveta coletora da vazão.

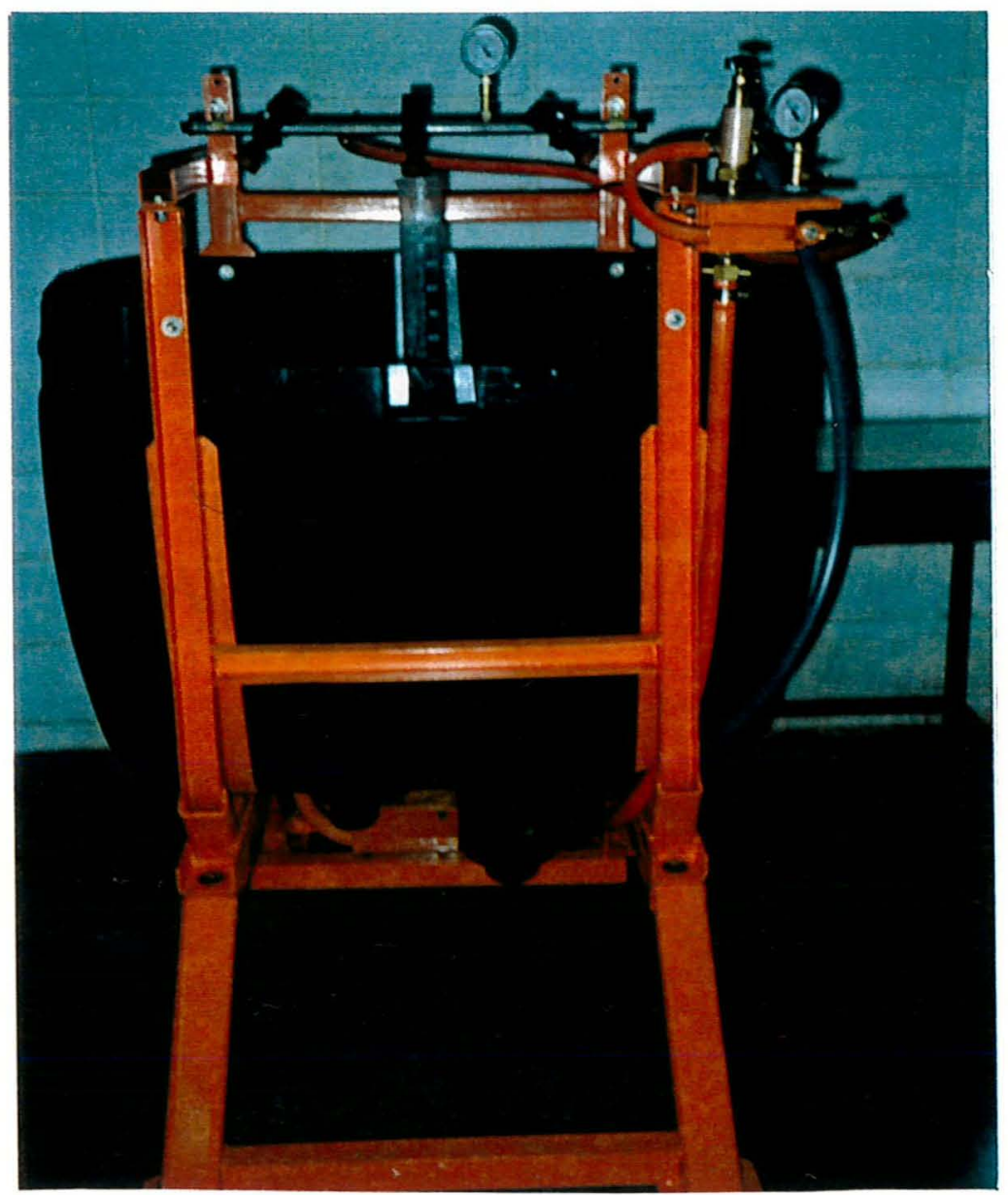

Figura 1. Vista parcial do tanque de coleta da vazão. 


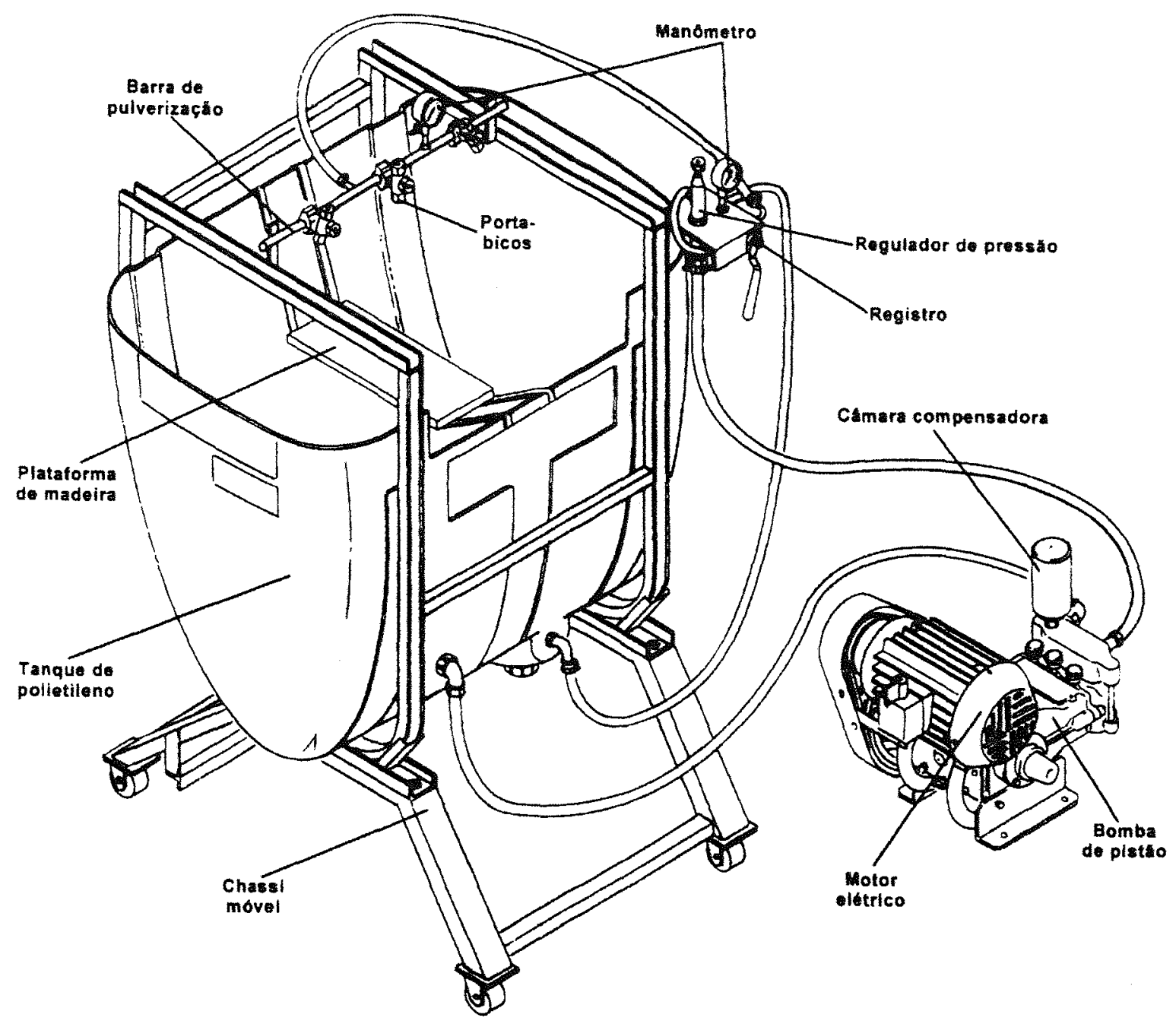

Figura 2. Esquema de funcionamento do tanque de coleta da vazão. 


\subsubsection{Tanque de desgaste}

Este equipamento tem a função de pulverizar a calda (água + abrasivo) através dos bicos, provocando o desgaste dos mesmos. Foi construído baseando-se em trabalhos realizados pelos autores citados (Corrêa, 1987; Gandolfo, 1995; Marquez et al., 1988, Ozkan et al., 1992a; Reed \& Ferrazza, 1984; Reichard et al. 1991) e no equipamento utilizado pelo Laboratório de Pulverização Agricola, da Empresa Jacto, para este fim. É constituído por 3 sistemas hidráulicos (Figuras 3 e 4 ), operando simultaneamente: a) sistema hidráulico pulverizador b) sistema hidráulico de agitação c) sistema hidráulico de arrefecimento.

a) Sistema hidráulico pulverizador :- Este é o circuito que pulveriza a calda pelos bicos, possuindo um tanque de polietileno, de forma afunilada, cortado em sua face superior, ficando a parte cortada como tampa do tanque, tendo este, capacidade para 300 litros, montado em um chassi móvel; uma bomba de pistão de 3 cilindros, acionada por um motor elétrico de 3 c.v. de potência, com vazão de $45 \mathrm{~V} / \mathrm{min}$., girando a $850 \mathrm{rpm}$ e câmara compensadora de 0,5 litros. Esta bomba succiona a calda a $1 / 3$ da altura do tanque e envia para o regulador de pressão. $O$ circuito possui um regulador de pressão de dois estágios (baixa e alta pressão) do tipo pressão constante, com registro de fecho rápido, retorno livre, manômetro e registro para seleção dos segmentos de barra. Cada uma das duas barras de pulverização possui um filtro de linha (malha 80), 15 porta-bicos comuns e manômetro para cada uma das barras. Os manômetros do regulador de pressão e das barras tem exatidão de $2 \%$ da pressão efetiva de trabalho $(276 \mathrm{kPa})$ e foram aferidos no Laboratório de Experimentação e Normalização de Engenharia da Empresa Máquinas Agrícolas Jacto S./A..

b) Sistema hidráulico de agitação :- Este circuito, combinado com a geometria do tanque, tem a função de manter a dispersão do material abrasivo no líquido através da agitação hidráulica. O sistema possui uma bomba centrífuga, acionada por um motor elétrico de 1,5 c.v. de potência, com vazão de $140 \mathrm{l} / \mathrm{min}$., girando a $3480 \mathrm{rpm}$. Esta 
bomba succiona a calda abrasiva do tanque e recalca para um ponto no fundo do mesmo e para dois ejetores cuja função é ampliar a agitação hidráulica. O retorno do circuito de pulverização também causa agitação hidráulica em um ponto estratégico dentro do tanque.

c) Sistema hidráulico de arrefecimento :- Este circuito tem a função de manter a temperatura da calda dentro do intervalo específico. Possui também, uma bomba centrífuga acionada por um motor elétrico de 1 c.v. de potência, com vazão de $80 \mathrm{l} / \mathrm{min}$., girando a $1730 \mathrm{rpm}$. Esta bomba succiona a calda do tanque e a faz passar por um radiador com capacidade de 2 litros, refrigerado por um ventilador de 0,25 c.v. de potência com diâmetro das pás de $30 \mathrm{~cm}$. Após circular pelo radiador a calda passa por uma serpentina de 20 metros posicionada no fundo de um tanque de polietileno, com capacidade de 500 litros, contendo água fria à temperatura ambiente e logo após retorna ao tanque servindo como agitação hidráulica entre os dois ejetores.

Os três motores elétricos possuem chaves de proteção magnética, sendo os sistemas, controlados eletricamente por um temporizador, marca Coel, tipo RTQD, com precisão de 15 minutos, que aciona apenas o desligamento dos sistemas, sendo que para ligar, é manual, pois devem iniciar o funcionamento em tempos diferentes. 
(a)

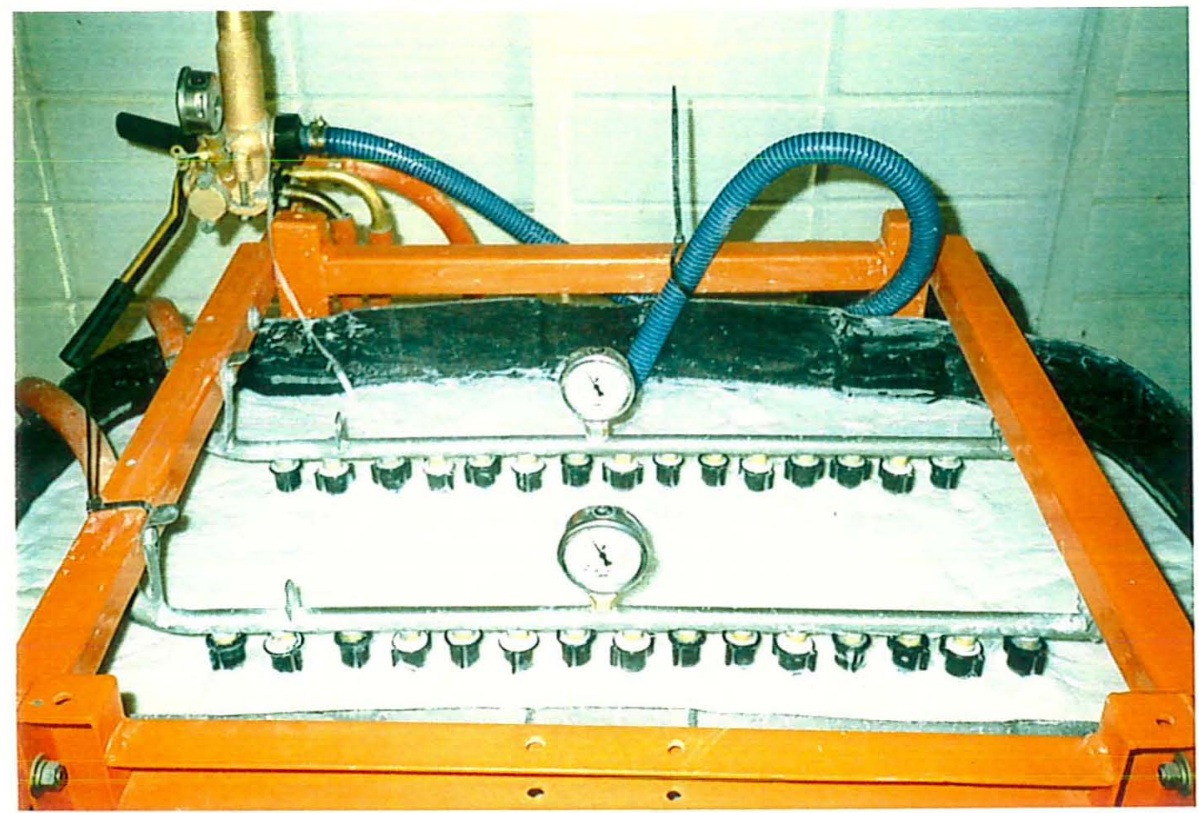

(b)

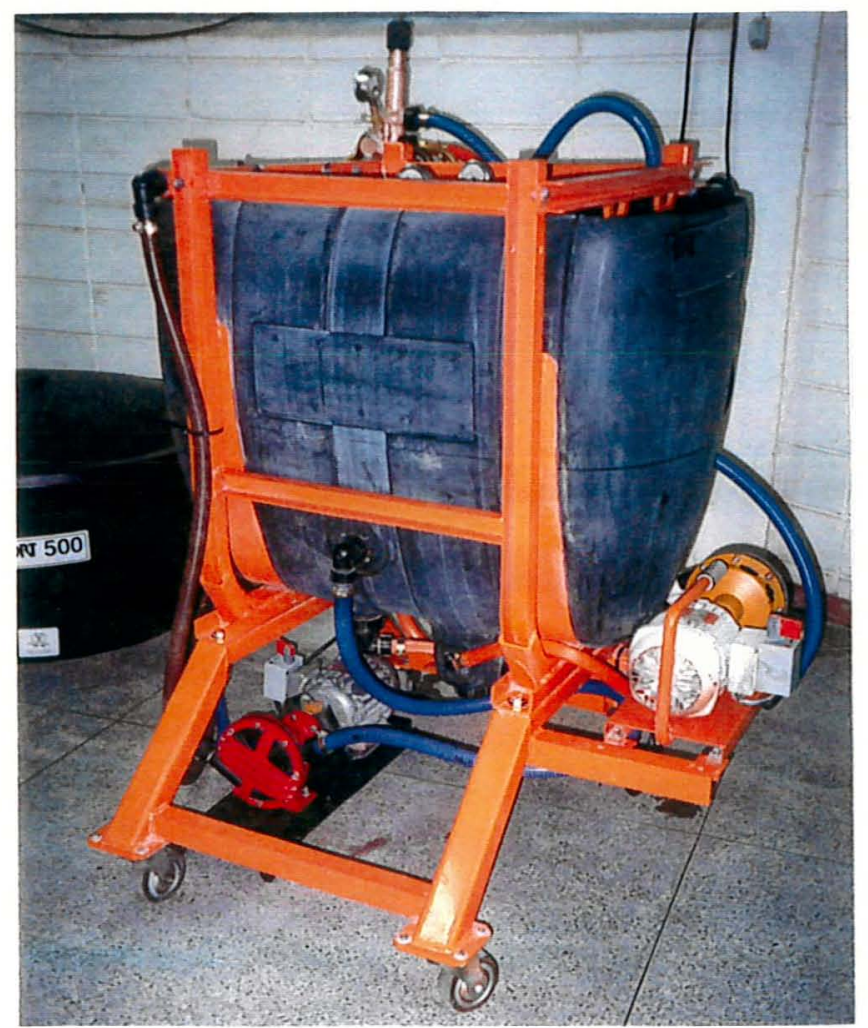

Figura 3. Vista parcial do tanque de desgaste: (a) Vista de topo, (b) Vista lateral 


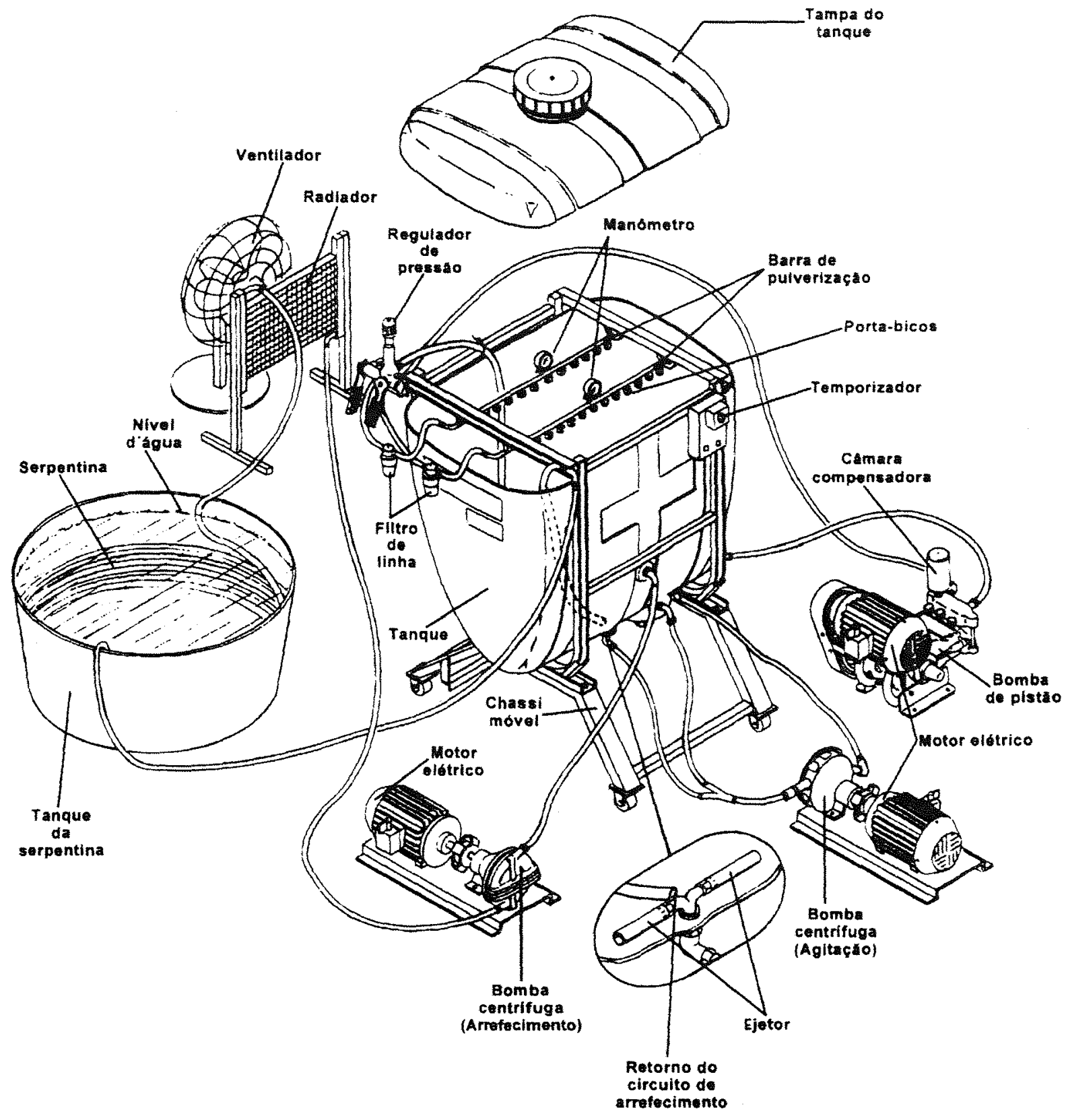

Figura 4. Esquema de funcionamento dos circuitos do tanque de desgaste. 


\subsubsection{Mesa de Canaletas}

O estudo do perfil de distribuição dos bicos foi efetuado em uma mesa de canaletas do Setor de Treinamento da Empresa Jacto, que atende as especificações da ABNT - NBR 13769 (1997) (Figuras 5 e 6). Esta mesa é constituída de uma plataforma com canaletas de paredes verticais distanciadas $25 \mathrm{~mm}$ entre si, com inclinação de $15 \%$. No término de cada canaleta está posicionado um tubo de vidro com diâmetro de 22 milímetros e capacidade de 150 mililitros, que é o coletor do líquido de ensaio. O circuito pulverizador da mesa de canaletas é composto por um tanque de 600 litros, uma bomba de pistão com vazão de 35 1/min., girando à $1100 \mathrm{rpm}$, comando regulador de pressão, manômetros para leituras de baixa e alta pressão com precisão de 2 e $5 \%$, respectivamente e suporte da barra que permite instalação de até 9 bicos para simulação da barra de pulverização. No ensaio específico, utilizou-se apenas um portabico com engate rápido, na altura de $40 \mathrm{~cm}$ das canaletas, e um manômetro de barra aferido, com exatidão de $2 \%$ da pressão efetiva de trabalho $(276 \mathrm{kPa})$.

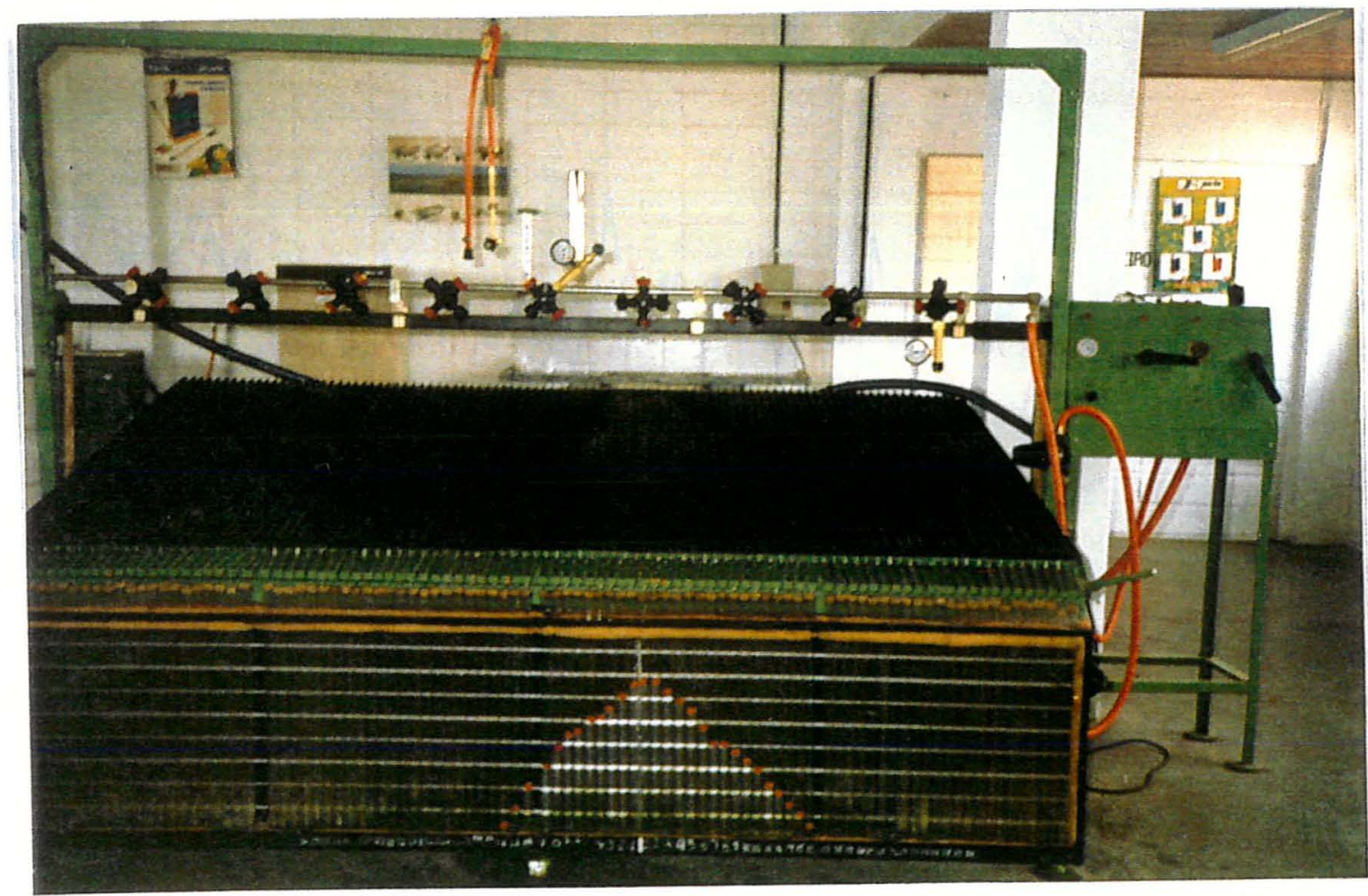

Figura 5. Vista parcial da mesa de canaletas. 


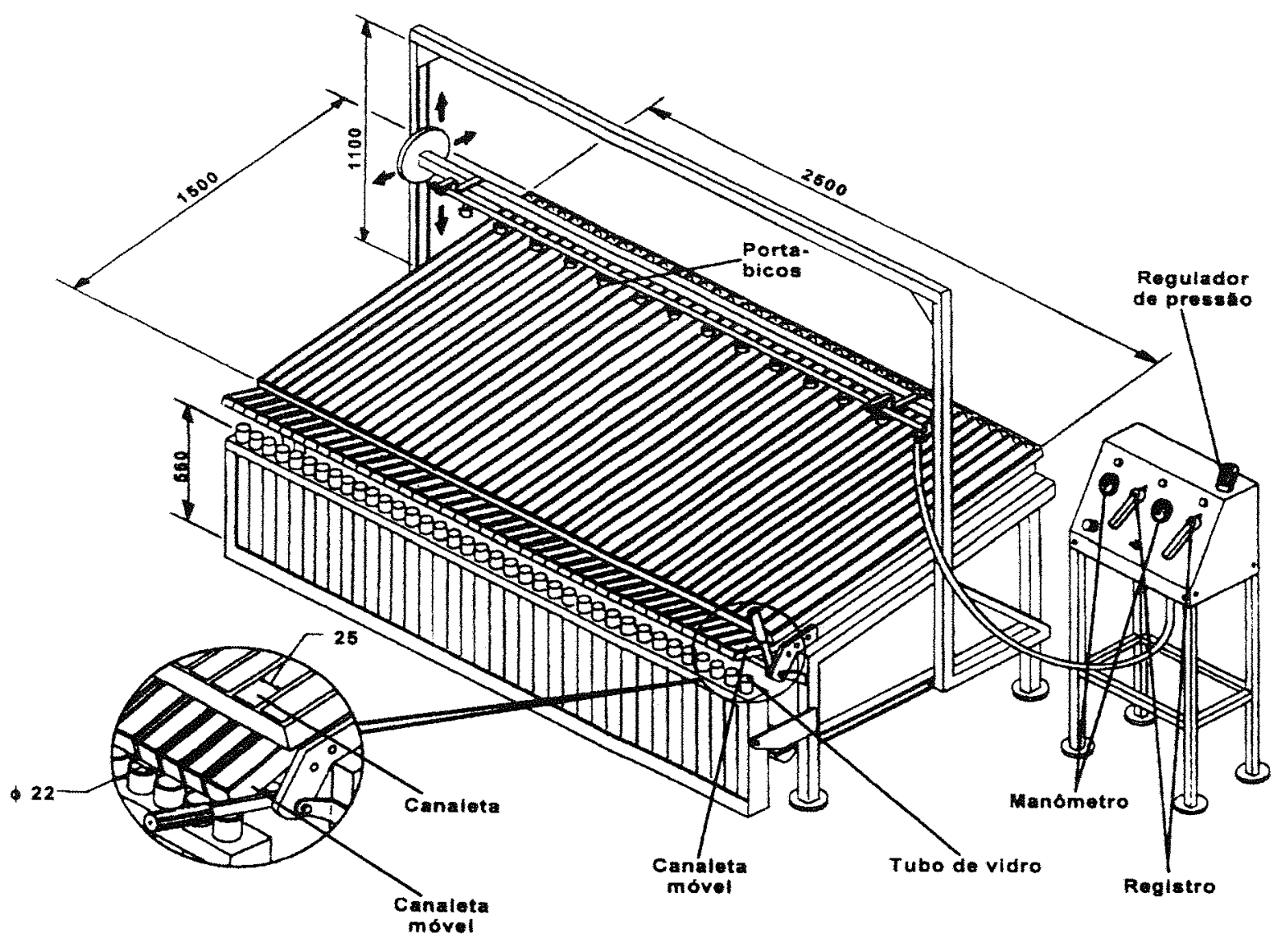

Figura 6. Esquema de detalhes da mesa de canaletas. 


\subsubsection{Projetor de Perfil}

$\mathrm{O}$ orifício dos bicos de jato plano tem formato de elipse e foi medido no sentido do diâmetro maior e menor, através da lente de ampliação de 10 vezes, e fotografado com lente de ampliação de 50 vezes, no projetor de perfil (Figura 7), marca Starrett Sigma, modelo HB400, com leitura digital em um processador marca QuadraChek 2000 com precisão de leitura de 0,001 milímetros (1 $\mu \mathrm{m})$. Este equipamento pertence ao Laboratório de Metrologia da Empresa Máquinas Agrícolas Jacto S./A..

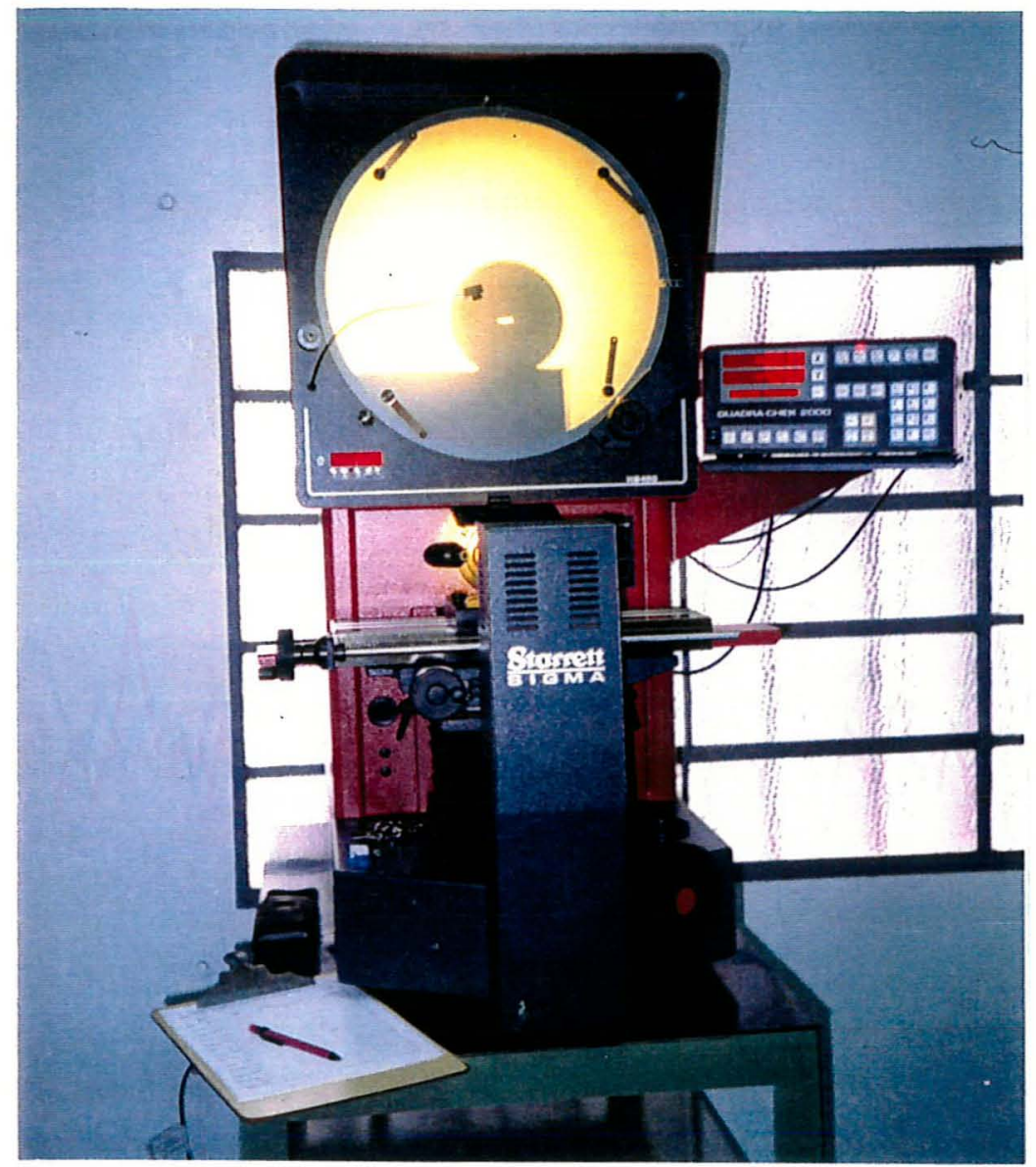

Figura 7. Vista parcial do Projetor de Perfil. 


\subsubsection{Aparelhagem}

- Peneira para análise e controle granulométricos, marca aBronzinox, malha 100 e 140 mesh $(0,150$ e 0,106 milimetros), pertencente ao Departamento de Cerâmica da Empresa Máquinas Agrícolas Jacto S./A.

- Balança eletrônica de precisão, marca Micronal, modelo B 6000, com campo de pesagem de zero a $6100 \mathrm{~g}$ e legibilidade de $0,1 \mathrm{~g}$, pertencente ao Laboratório de Análises de Solo da Fundação Shunji Nishimura de Tecnologia.

- Cronômetro digital com precisão de 0,01 centésimo de segundo.

- Proveta coletora com capacidade de 2000 mililitros e precisão de leitura de 10 mililitros.

- Régua graduada com precisão de \pm 1 milímetro.

- Termômetro com escala de -10 a $110^{\circ} \mathrm{C}$ e precisão de $2{ }^{\circ} \mathrm{C}$.

- Manômetro de barra com escala de zero a 100 psi e exatidão de $2 \%$ da pressão efetiva de trabalho $(276 \mathrm{kPa})$.

\subsubsection{Produtos}

Para realização deste trabalho foram usados três produtos principais: a água, o material abrasivo e o bico de pulverização de jato plano.

\subsubsection{1 Água}

Utilizou-se água de torneira, proveniente de um poço semi-artesiano localizado na instituição onde foi realizado o ensaio. 


\subsubsection{Materiais Abrasivos}

Foram utilizados nove materiais abrasivos, sintéticos ou minerais, abaixo relacionados (Figura 8 )

1 - Óxido de alumínio marrom (Corindon) grão 800 - diâmetro médio 15,5 um produzido por Alcoa Alumínio S.A., Salto, S.P.

2 - Carbeto de silício-SIC 800 - diâmetro médio $15,5 \mu \mathrm{m}$, produzido por Alcoa Aluminio S.A., Salto, S.P

3 - Caulim O.B. 2150 - com distribuição do tamanho de partículas entre

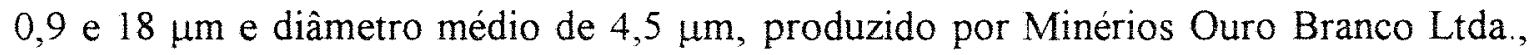
São Paulo, S.P.

4 - Alumina calcinada APC-2011 SG - com distribuição do tamanho de partículas entre 0,5 e $10 \mu \mathrm{m}$ e diâmetro médio $3 \mu \mathrm{m}$, produzida por Alcoa Alumínio S.A., Poços de Caldas, M.G.

5 - Carbeto de silício-SIC 240 - diâmetro médio $55 \mu \mathrm{m}$, produzido por Alcoa Aluminio S.A., Salto, S.P.

6 - Carbeto de silício-SIC 500 - diâmetro médio $22 \mu \mathrm{m}$, produzido por Alcoa Alumínio S.A., Salto, S.P.

7 - Óxido de alumínio branco (FFF) com distribuição do tamanho de partículas entre 1 e $170 \mu \mathrm{m}$ e diâmetro médio de $46 \mu \mathrm{m}$, produzido por Alcoa Alumínio S.A., Salto, S.P.

8 - Bióxido de silício - Tixosil 73, com distribuição do tamanho de particulas entre 0,5 e $180 \mu \mathrm{m}$ e diâmetro médio de $12 \mu \mathrm{m}$, produzido por Rhodia S.A., Paulínea, S.P..

9 - Areia de sílica - quartzo - areia de fundição para shellmold, com granulometria entre 106 a $150 \mu \mathrm{m}$, proveniente da Mineração Jundu S.A., Descalvado, S.P. 

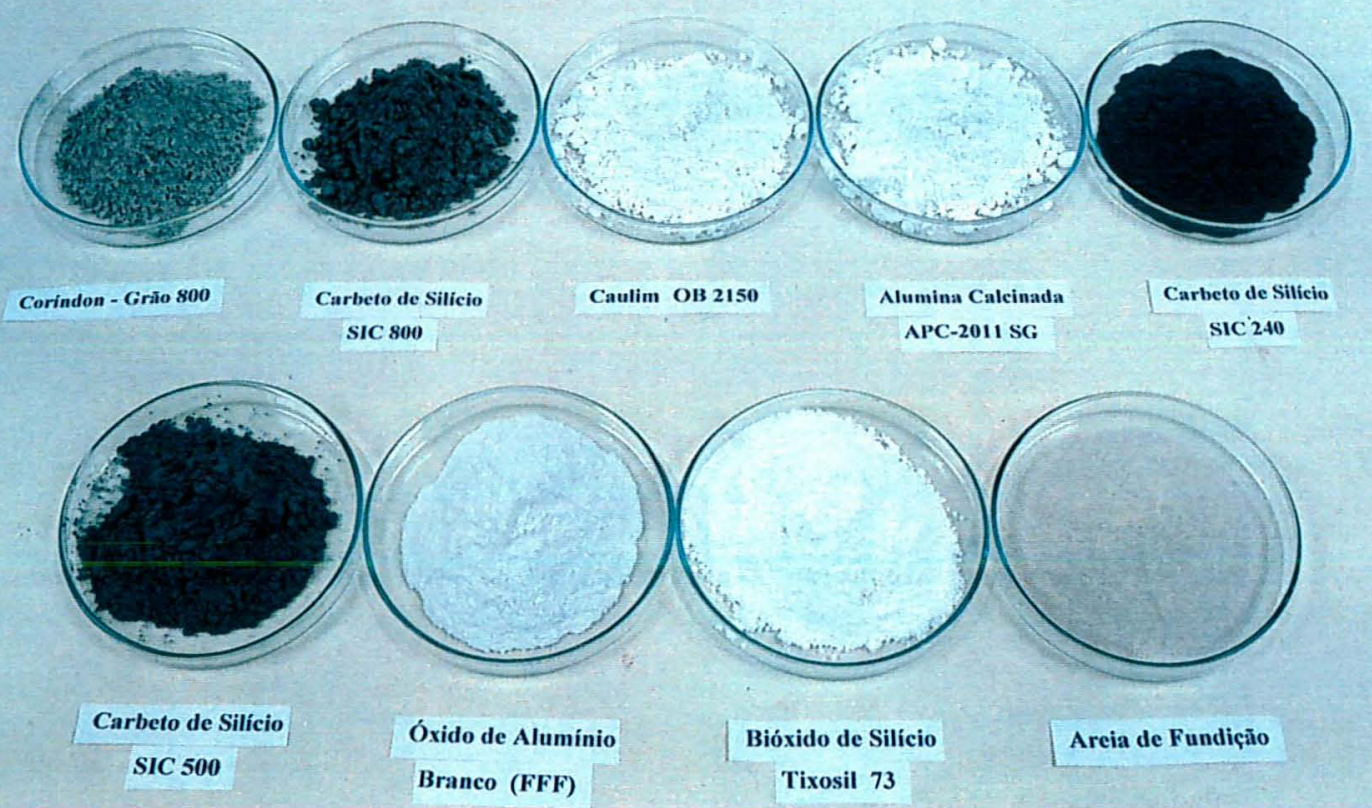

Figura 8. Materiais abrasivos utilizados no presente estudo.

\subsubsection{Bicos Pulverizadores de Jato Plano}

Foram utilizados seis bicos abaixo especificados (Figura 9):

1 - Bico de cerâmica - série XR TeeJet- 110.03 VK (uso ampliado), fabricado e comercializado por Spraying Systems Co.

2 - Bico de cerâmica - série ADI - 110.03 (baixa-deriva), fabricado pela Albuz (França) e comercializado por Máquinas Agrícolas Jacto S.A.

3 - Bico de kematal - série UF - 110.03 (uso ampliado), fabricado pela Spray International Ltd (Inglaterra) e comercializado por Máquinas Agrícolas Jacto S.A. 
4 - Bico de kematal - série LD - 110.03 (baixa-deriva), fabricado pela Spray International Ltd (Inglaterra) e comercializado por Máquinas Agrícolas Jacto S.A. 5 - Bico de aço inoxidável - série XR TeeJet - 110.03 VS (uso ampliado), fabricado e comercializado por Spraying Systems Co.

6 - Bico de aço inoxidável - série DG TeeJet - 110.03 VS (baixa-deriva), fabricado e comercializado por Spraying Systems Co.
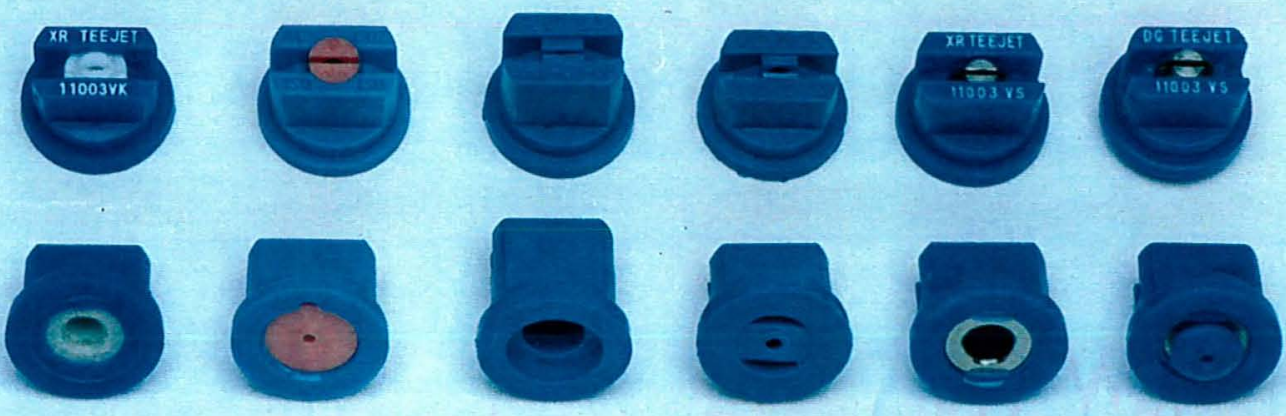

Cerâmica-XR

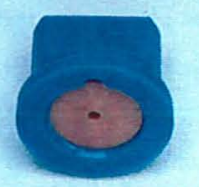

Cerâmica-ADI
A co Inox-XR

Aço Inox-DG:

Figura 9. Vista parcial dos bicos de jato plano utilizados no presente estudo. 


\subsection{Métodos}

O presente trabalho seguiu a Norma de métodos de ensaio de bicos da ABNT, NBR 13769 (1997), 'Bico de pulverização agricola - Métodos de ensaio", porém, além dos materiais abrasivos indicados por esta, foram utilizados outros, baseando-se em: outras normas (ASAE Standard, S471, 1995; NF U 26-110, 1979 ; ISO 5682/1, 1997), materiais utilizados por pesquisadores e indicações de fabricantes de abrasivos A terminologia utilizada na descrição dos componentes segue a NBR 12936 Pulverizador Agrícola - Terminologia (1993).

Os ensaios foram desenvolvidos em condições laboratoriais, portanto, os parâmetros temperatura ambiente, velocidade do vento, deriva e evaporação, não foram considerados como variáveis nas determinações dos dados.

\subsubsection{Seleção dos produtos abrasivos}

A seleção dos produtos abrasivos, sintético ou mineral, baseou-se nos itens supra citados. Foram pesquisados as seguintes indústrias e mineradoras:

- Alcoa Alumínio, Salto, S.P.

- Alcoa Alumínio, Poços de Caldas, M.G.

- Elfusa, São João da Boa Vista, S.P.

- Norton, Lorena, S.P.

- Rhodia, Paulínia, S.P.

- Minérios Ouro Branco, São Paulo, S.P.

- Mineração Jundú, Descalvado, S.P.

- Minasolo, São Paulo, S.P.

- Costalco, Ponta - Grossa, P.R.

- Micro-Service- Indústria Química, São Paulo, S.P. 
Alguns abrasivos normalizados não são mais encontrados no mercado, na granulometria recomendada, ou então, não são mais um produto de linha nas industrias de materiais abrasivos. Neste caso procurou-se um material, através de informações do fabricante de abrasivos, que tivesse características físico-químicas semelhantes ao citado na respectiva Norma e que fosse facilmente encontrado comercialmente.

Foram selecionados produtos abrasivos para os testes preliminares, onde obteve-se medidas do aumento da vazão, em função do tempo (horas), devido ao desgaste do orificio do bico, pela ação da passagem do abrasivo (calda).

O óxido de alumínio (Coríndon) é citado na Norma AFNOR (Association Française de Normalisation) NF U 26-110, (1979), que especifica sua granulometria e composição química. O coríndon grão 800 encontrado, atende esta especificação, porém, nesta granulometria, apesar de encontrado em estoque, não é mais um produto de linha nas industrias do ramo, pois, está sendo substituído pelo carbeto de silício, que tem o processo de fabricação mais simplificado, o que diminui o custo de produção (Vendrasco $\left.{ }^{4}, 1996\right)$

O carbeto de silício, grão 800 , material indicado pelo fabricante foi utilizado para um comparativo com o coríndon, que também é grão 800 (diâmetro médio $=15,5 \mu \mathrm{m}$ ). Estes dois materiais são similares, com alto grau de abrasividade e foram utilizados na concentração indicada na Norma acima citada, que é de $20 \mathrm{~g} / \mathrm{l}$ de água

O caulim é um produto mineral, de baixo grau de abrasividade, citado na Norma NBR 13762 (1997) para teste de desgaste acelerado de bicos confeccionados em latão e plástico e na Norma ASAE Standards : ASAE S 471 Dec 95, como o agente abrasivo a ser utilizado em testes de bicos confeccionados em latão, aço inoxidável e plástico. O caulim O.B. 2150, com diâmetro médio de 4,5 $\mu \mathrm{m}$, atende as especificações granulométricas das duas Normas supra citadas, sendo utilizado na concentração citada na Norma ASAE Standards: ASAE S 471 Dec 95, que é de $60 \mathrm{~g} / 1$ de água.

\footnotetext{
${ }^{4}$ VENDRASCO, S.L. (Alcoa Aluminio, S.A.) Comunicação pessoal, 1996.
} 
A alumina calcinada APC 2011 é um produto de média abrasividade que foi utilizado na concentração de $20 \mathrm{~g} / \mathrm{l}$ de água, procurando alguma similaridade com 0 caulim, visto que a alumina é um produto sintético, não variando em função da fonte de extração, além de apresentar baixíssima granulometria e ser facilmente encontrada no mercado.

Os materiais abrasivos carbeto de silício, SIC 500 e SIC 240, foram selecionados após os ensaios feitos com o SIC 800, que não apresentou abrasividade suficiente para desgastar os bicos confeccionados em cerâmica, utilizando então, o carbeto, em granulometrias maiores.

O óxido do alumínio branco (FFF) é o material que atende as especificações do abrasivo citado na segunda edição da Norma ISO 5682-1 (1996). Esta edição foi lançada em 11/06/1997, quando os abrasivos anteriores já haviam sido selecionados e realizados os testes. Este material portanto, foi escolhido como abrasivo para realização do teste final, pois é uma Norma recente e um material facilmente encontrado no mercado.

O bióxido de silício é o material indicado pela Organização Mundial da Saúde - OMS (1976) e foi utilizado por Bode et al.(1984) e pela Hard International (1995). Zhu et al. (1995), utilizaram o caulim para testes com bicos confeccionados em material plástico e o bióxido de silício para os bicos confeccionados nos demais materiais. O tixosil 73, produzido pela Rhodia S.A., em Paulínia, S.P., tem principal aplicação como agente abrasivo para dentifrícios, e é similar ao Hi-Sil 233 produzido pela PPG Industries Inc., Pittsburg, Pa, USA, utilizado por Zhu et al. (1995).

A areia de silícia - areia de fundição para shellmold é o material abrasivo recomendado pela ABNT, NBR 13769 (1977), para teste de bicos de alta resistência a abrasão, que foi indicado na Norma, baseando-se em trabalhos realizados por Corrêa (1987) e Corrêa (1988) e em ensaios realizados pela Empresa Máquinas Agrícolas Jacto S.A., Pompéia, S.P. 


\subsubsection{Seleção dos bicos de pulverização}

Os bicos estudados variaram quanto ao material de confecção e quanto ao tipo do jato plano, isto é, baixa deriva (DG, LD) e uso ampliado (XR, UF)

A seleção dos específicos bicos, quanto ao material de confeç̧ão, tipo de jato plano, foi com base na maior demanda do mercado nacional e internacional (Christofoletti ${ }^{5}$, 1997).

Foram selecionados os bicos confeccionados em aço inoxidável, kematal e cerâmica, sendo cada material em jato plano de baixa deriva e jato plano de uso ampliado. A vazão nominal dos espécimes são similares em aproximadamente 1,18 $1 / \mathrm{min}$, à $40 \mathrm{psi}(0,3$ galões $/ \mathrm{min})$, e o ângulo do jato é de $110^{\circ}$ para todos os modelos.

Os bicos de baixa deriva apresentam um orificio circular, antes do orificio elíptico final que produz uma queda de pressão e da velocidade da gota, e consequentemente um tamanho de gota médio, maior que os bicos de jato plano convencional, reduzindo a proporção de pequenas gotas produzidas pelo bico, que são susceptiveis a deriva (Barnett \& Matthews, 1992 ; Nordbo et al, 1995 e Thornhill \& Matthews, 1996).

Os bicos de uso ampliado podem ser utilizados em um intervalo grande de pressão, isto é de 98 a $392 \mathrm{kPa}$ (1 a 4 bar). São projetados para prover um perfil de distribuição homogêneo, mesmo quando trabalhando a baixas pressões ( 1 bar), isto é, reduzem a deriva nas pressões baixas e proporcionam melhor cobertura nas pressões altas (Thornhill \& Matthews, 1996).

\footnotetext{
${ }^{5}$ Christofoletti, J.C. ( Spraying Systems Co. ) Comunicação pessoal. 1997.
} 


\subsubsection{Determinação do diâmetro dos tubos da barra de pulverização}

Com base na vazão total dos bicos na barra em $1 /$ min e na velocidade do líquido em $\mathrm{m} / \mathrm{s}$, normal para linhas de pressão, determinou-se através de ábaco o melhor diâmetro interno do tubo (Palmieri, 1987). Para validação desse resultado foram testados

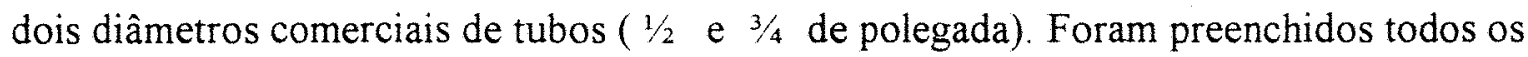
porta-bicos, num total de 14 por barra, com bicos de kematal UF, que foram submetidos a 10 horas de desgaste, na pressão de $276 \mathrm{kPa}$, utilizando o abrasivo coríndon grão 800 na concentração de $20 \mathrm{~g} / \mathrm{l}$. Os bicos foram numerados de 1 a 14 , sendo o bico número 1 , o primeiro bico na entrada do líquido, com o final da barra fechado (Figura 3).

O objetivo deste teste foi detectar possiveis diferenças no aumento porcentual da vazão entre o início e o final da barra.

\subsubsection{Determinação da vazão inicial dos bicos}

As vazões iniciais dos 50 exemplares, escolhidos aleatoriamente, para os seis diferentes tipos de bicos foram coletadas no equipamento denominado tanque de coleta da vazão, utilizando proveta e cronômetro citados no item 3.1 .3 , com tempo de coleta igual a 60 segundos, sendo feitas três repetições de leitura, na pressão de $276 \mathrm{kPa}$.

O objetivo da determinação da vazão inicial foi de obter os valores da vazão de cada exemplar, para posteriormente selecionar três exemplares de cada tipo com a mesma vazão, para uso no pré-teste e teste final.

Com base nos dados do catálogo do fabricante foi estimada uma equação de regressão para determinar a vazão nominal dos bicos de aço inox XR e DG, e de cerâmica XR, fabricados por Spraying Systems Co., para uma pressão de $276 \mathrm{kPa}$, pressão esta, empregada no teste. Isso foi feito devido a vazão nominal desses bicos, apresentadas no catálogo, ser referente a pressão de $300 \mathrm{kPa}$. 


\subsubsection{Condução e avaliação dos ensaios no pré-teste}

Os ensaios denominados de pré-teste, tiveram como objetivo selecionar dentre os nove abrasivos pré-selecionados (item 3.2.1), os que apresentaram melhor atuação para realização de teste de desgaste acelerado de bicos pulverizadores. Outro objetivo foi a averiguação do tempo de teste consumido para alcançar determinados níveis de desgaste, para cada um dos bicos, que serviram de orientação no teste final.

Foram utilizados os equipamentos tanque de desgaste, que promoveu o aumento da vazão de forma acelerada através do uso de caldas abrasivas. Também utilizou-se o tanque de coleta da vazão para obter os valores desse aumento, em intervalos de tempos pré-fixados.

O pré-teste consistiu de nove ensaios com os produtos abrasivos descritos no item 3.1.4.2. Em cada um desses ensaios, utilizou-se seis tipos de bicos (Figura 9) como variáveis, sendo feitas três repetições. Estas três repetições foram selecionadas com base na vazão inicial, tendo estas, o mesmo valor de vazão. Os tempos de coleta da vazão foram pré-fixados em $0,1,2,4,6,5,10,15,20,25,30,40$ e 50 horas, tomando como tempo máximo 50 horas, que é estipulado na Norma NBR 13769 (1997). Em alguns casos ainda, foram inseridos alguns tempos para melhor estudo do comportamento.

Para a retomada do funcionamento do tanque de desgaste, no tempo seguinte acionava-se o sistema de agitação e o sistema de arrefecimento 10 minutos antes do sistema de pulverização, a fim de homogeneizar a calda. A temperatura da calda medida nos intervalos de tempo mencionados, manteve-se no intervalo de 25 a $35^{\circ} \mathrm{C}$. O abrasivo Areia de Fundição foi trocado a cada 10 horas de teste, seguindo a Norma NBR 13769 (1997), sendo que, os demais abrasivos foram utilizados durante o tempo total do teste com base na Norma ASAE S471 - Dec 95 (1996), que indica o tempo de troca para o Caulim, através da fórmula $T=300 . \mathrm{V} / \mathrm{Q}$; sendo $\mathrm{T}=$ intervalo de troca da calda (horas); $\mathrm{V}=$ volume da calda (litros) e $\mathrm{Q}=$ vazão total dos bicos (litros/hora). 
Em cada um dos tempos, foi medida a vazão em $1 /$ min, na pressão de $276 \mathrm{kPa}$ para os 18 bicos, sendo posteriormente transformada em aumento porcentual, relativo a vazão inicial, para avaliação da resistência ao desgaste dos bicos. Foram realizadas análises de variância para os ensaios nos diversos tempos de medições (horas), seguindo o delineamento inteiramente ao acaso (Gomes, 1984), e a seguir aplicado o teste de Tukey ao nível de $5 \%$ de probabilidade, a fim de discriminar possiveis diferenças entre os tratamentos. Assim as interpretações se restringiram às diferenças de médias do aumento porcentual da vazão dos bicos para aquele tempo. Com base na média do aumento porcentual da vazão em função do tempo, foram realizadas estimativas de equações de regressão, para representar o comportamento desse aumento para cada um dos bicos, quando sob a ação dos diferentes abrasivos. Foram feitas avaliações através de gráficos, que representaram o comportamento das médias ao longo do tempo, para os diferentes bicos em cada abrasivo e para os diversos abrasivos em cada bico.

A fim de estabelecer relações de resistência ao desgaste entre os bicos, envolvendo todos os abrasivos, comparou-se relativamente os aumentos porcentuais da vazão. Os resultados foram obtidos e expressos através de um valor, definido pela relação entre $o$ aumento porcentual do bico de aço inox $\mathrm{XR}$ com os demais, considerando este, como material de referência por apresentar as maiores médias, tendo recebido o valor 1 . Desta mesma forma comparou-se também, os bicos de baixa deriva com os bicos de uso ampliado do mesmo material de confecção.

\subsubsection{Condução e avaliação dos ensaios no teste final}

O teste final consistiu em analisar os efeitos do desgaste, provocado pelo abrasivo selecionado, sobre os seguintes parâmetros funcionais do bico: tempo, diâmetros da elipse e uniformidade de distribuição, quando alcançados os níveis de desgaste $0,5,10,20,30,40$ e $50 \%$ de aumento da vazão, níveis estes que atendem a Norma NBR 13769 (1997). 
Foi selecionado para o teste final apenas o abrasivo Óxido de Alumínio Branco (FFF) por ser indicado na Norma ISO 5682-1 (1997). Esta é a segunda edição da Norma, que foi lançada em 11/06/97, cinco meses após o lançamento da Norma NBR 13769 (1997), que baseia-se na Norma ISO 5682-1 (1981). Nesta época já havia sido feito o planejamento desse trabalho e realizados 4 ensaios no pré-teste. Procurou-se então o abrasivo indicado na nova Norma para realização do ensaio no pré-teste e posteriormente no teste final.

Era pretendido utilizar o abrasivo Caulim no teste final por ser citado na Norma ASAE, S471 Dec 95 (1996), porém, após os ensaios realizados no pré-teste com este material, verificou-se baixos niveis de desgaste para o tempo de realização do teste, principalmente para os bicos de cerâmica. Assim sendo, não foi possível a realização das avaliações do teste final com este abrasivo.

\subsubsection{Determinação dos tempos para alcançar os níveis de desgaste}

Para a determinação dos tempos para alcançar os niveis de desgaste préfixados, utilizou-se os mesmos equipamentos empregados no pré-teste. Porém, no teste final, ao contrário do pré-teste, fixou-se níveis de aumento porcentual da vazão, medindo o tempo (horas) para alcançar esses níveis, baseado nos resultados do pré-teste com abrasivo Óxido de Alumínio Branco (FFF). A pressão de operação tanto na coleta da vazão quanto no tanque de desgaste foi padronizada em $276 \mathrm{kPa}$, sendo corrigida à medida que os bicos se desgastavam. Mediu-se a vazão no início do ensaio e a intervalos periódicos, segundo a velocidade de desgaste de cada bico. Foi escolhido intervalos de medições apropriados para obter os aumentos de vazão próximos dos niveis pré-fixados, obtendo assim o tempo necessário para alcançar cada um dos níveis. Neste ensaio tomou-se seis tipos de bicos como fator de tratamento, sendo feitas três repetições. Estas três repetições foram selecionadas com base nas vazão inicial, tendo estas, o mesmo valor. 
Foi medido o tempo para alcançar cada um dos níveis de desgaste $(0,5$, $10,20,30,40$ e 50\%), para avaliação da resistência ao desgaste dos bicos. Foram realizadas análises de variância para os diversos níveis de desgaste (\%), seguindo o delineamento inteiramente ao acaso (Gomes, 1984), e a seguir aplicado o teste de Tukey ao nível de $5 \%$ de probabilidade, a fim de discriminar possíveis diferenças entre os tratamentos (bicos). Essas análises foram feitas até o nível 30\%, pois para os níveis de 40 e $50 \%$ não havia graus de liberdade suficiente, em razão do baixo número de tratamentos, pois os bicos de cerâmica XR e ADI e de aço inox DG não atingiram estes níveis durante as 50 horas de teste. Assim as interpretações foram feitas através das diferenças de médias do tempo para aquele nivel desgaste. Com base na média do tempo em função do nivel de desgaste, foram realizadas estimativas de equações de regressão para representar o comportamento do tempo.

\subsubsection{Determinação dos diâmetros da elipse}

Para a determinação dos diâmetros da elipse, utilizou-se o equipamento Projetor de Perfil, descrito no item 3.1.2.4, onde ampliava-se o orificio do bico que tem formato de elipse, sendo esta medida no sentido do diâmetro maior $(X)$ e menor $(\mathrm{Y})(\mathrm{mm})$.

Estas medições foram feitas com três repetições para cada um dos niveis de desgaste $(0,5,10,20,30,40$ e 50\%), para avaliação do comportamento dos diâmetros em função do desgaste. Realizou-se análises de variância para os diversos níveis de desgaste (\%), seguindo o delineamento inteiramente ao acaso (Gomes, 1984), e a seguir aplicado o teste de Tukey ao nível de $5 \%$ de probabilidade, a fim de discriminar possíveis diferenças entre os tratamentos (bicos). Essas análises também foram feitas até o nível $30 \%$, pois para os níveis de 40 e $50 \%$ não havia graus de liberdade suficiente, em razão do baixo número de tratamentos, pois os bicos de cerâmica XR e ADI e de aço inox DG não atingiram estes níveis durante as 50 horas de teste. Assim as interpretações 
foram feitas através das diferenças de médias do tempo para aquele nivel desgaste. Com base na média do tempo em função do nível de desgaste, foram realizadas estimativas de equações de regressão para representar o comportamento do tempo. Todas estas análises foram realizadas tanto para o diâmetro maior $(\mathrm{X})$ quanto para o diâmetro menor $(\mathrm{Y})$.

\subsubsection{Determinação do perfil de distribuição}

Os valores do perfil de distribuição foram medidos no equipamento Mesa de Canaleta, descrito no item 2.1.2.3 e mostrado nas Figuras 5 e 6, para cada um dos bicos nos diversos níveis de desgaste, sendo coletado um bico de cada vez, montado numa barra ajustável no centro da mesma. Foi medida a altura $(\mathrm{cm})$ de cada um dos tubos que continha o líquido, sendo depois transformada em volume $(\mathrm{ml})$. A pressão de pulverização na mesa de canaletas, foi de $276 \mathrm{kPa}$, estando todos os bicos a uma altura de $40 \mathrm{~cm}$ do pico da canaleta central, altura esta indicada pelo fabricante do bico como a altura de trabalho da barra de pulverização para bicos de $110^{\circ}$. A coleta do líquido, para cada um dos bicos, foi interrompida assim que o volume coletado em qualquer um dos tubos atingiu 90\% da sua capacidade (NBR 13769, 1997).

Com base nas médias dos volumes coletados nas três repetições, foram feitas avaliações de gráficos que representaram o comportamento do perfil de distribuição médio de cada bico nos diferentes níveis de desgaste.

De posse dos perfis de distribuição médio para cada bico e em cada nível de desgaste, simulou-se a constituição de uma barra de pulverização, com 4 bicos espaçados a $50 \mathrm{~cm}$ (Figura 10), espaçamento este, indicado pelo fabricante. A uniformidade de distribuição foi medida pelo $\mathrm{CV}$, obtido pelo volume contido nas canaletas, entre dois bicos consecutivos, através da simulação do cruzamento dos jatos, que garantiu a sobreposição. As medidas obtidas do $\mathrm{CV}$ são válidas apenas para o espaçamento, altura e pressão empregadas neste estudo. 
$\mathrm{O}$ valor do $\mathrm{CV}$ foi mostrado através de tabela e gráfico, e teve como objetivo avaliar a influência do desgaste na uniformidade de distribuição do líquido, pelos bicos.

Para verificação da representatividade do perfil de distribuição médio, estudou-se o comportamento do CV para cada canaleta, nos diferentes niveis de desgaste e a simetria volumétrica da distribuição.

Os ângulos do jato foram determinados através de cálculo trigonométrico com base na altura do bico até a mesa de canaleta $(40 \mathrm{~cm})$ e na largura da faixa de deposição. Para cada repetição, o ângulo foi obtido pela soma dos àngulos de cada metade do jato, sendo tomado para avaliação, o ângulo médio das três repetições em cada nível de desgaste. $O$ ângulo médio do bico quando novo, foi comparado com o ângulo nominal. Os resultados foram mostrados e representados graficamente.

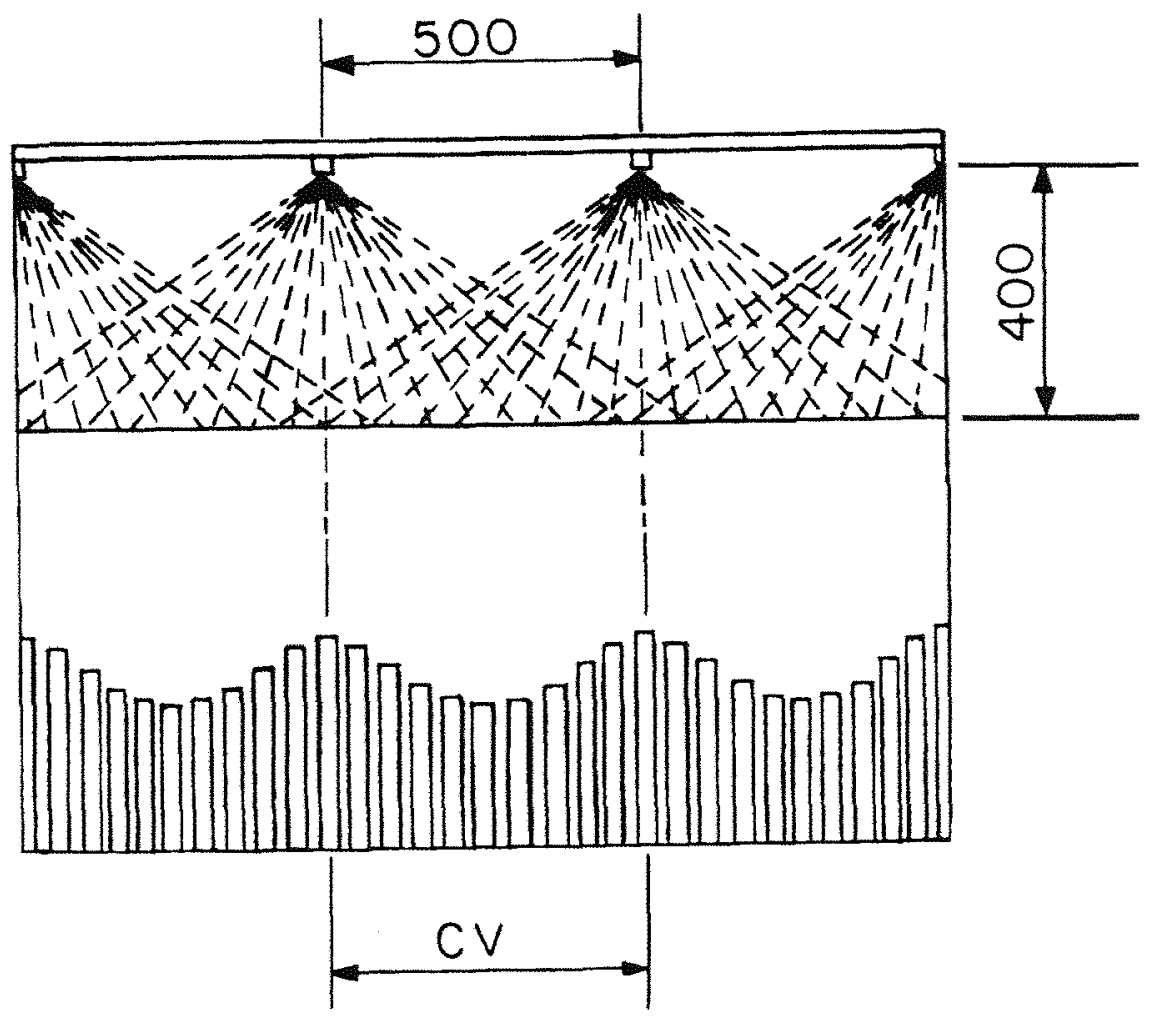

Figura 10. Esquema explicativo da obtenção do CV. 


\section{RIESULTADOS E DISCUSSÃO}

\subsection{Avaliação do diâmetro dos tubos da barra de pulverização}

O Gráfico da figura 11 mostra a vazão inicial e o aumento desta, com dez horas de funcionamento em teste de desgaste acelerado, para os quatorze bicos colocados ao longo das barras com os diâmetros de $3 / 4$ e $1 / 2$ polegadas. As barras possuem a entrada do líquido na lateral em que está posicionado o bico número um, sendo fechada no final, logo a frente do bico quatorze (Figura 3). Observando-se o gráfico,

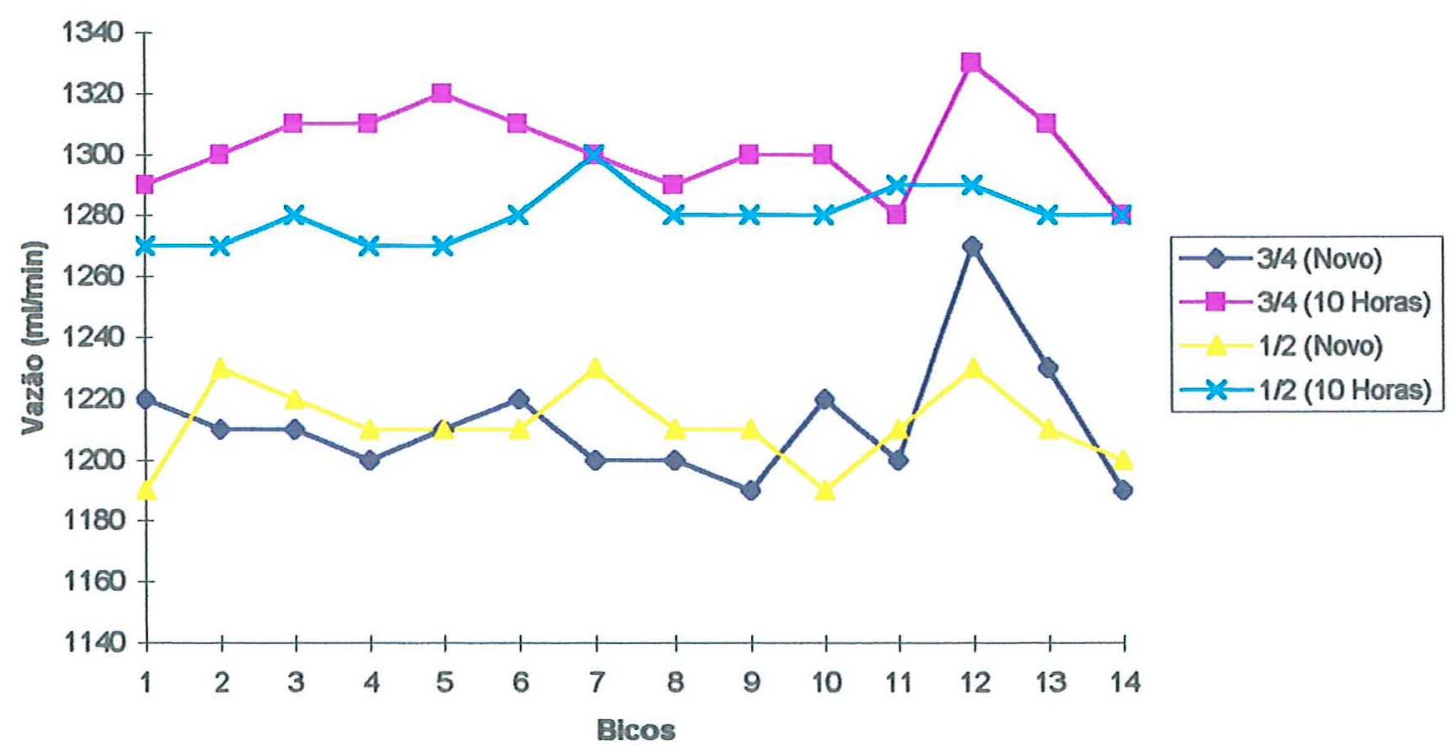

Figura 11. Gráfico da variação da vazão dos bicos, para os diferentes diâmetros do tubo da barra de pulverização 
verifica-se que os valores não apresentaram nenhuma tendenciosidade com respeito ao desgaste na sequência dos bicos colocados na barra, para os dois diâmetros de tubos, isto é, a diferença entre a vazão do bico novo e a vazão após 10 horas mantiveram-se constante ao longo da barra. Este teste teve por objetivo, detectar possiveis diferenças no desgaste do bico entre o início e o final da barra

Apesar de não haver diferenças aparentes entre os dois diâmetros, foi escolhido o tubo com diâmetro de $3 / 4$, em razão deste apresentar a melhor velocidade de escoamento do líquido para linhas de pressão para a especifica vazão da barra, segundo ábaco para escolha do diâmetro interno de tubulações hidráulicas (Palmieri, 1988). Contudo, durante todos os testes, sempre que os bicos foram colocados ou recolocados na barra, estes eram posicionados aleatoriamente nos porta-bicos.

\subsection{Análise da vazão inicial dos bicos}

Os valores das vazões médias de três repetições de leitura de cada um dos cinqüenta exemplares, para cada um dos seis tipos de bico, bem como as médias, coeficientes de variação, vazão nominal e desvio médio de cada um desses tipos, são apresentados na Tabela 1 .

Verifica-se uma variação do coeficiente de variação da ordem de 1,02 a $2,63 \%$, o que mostra uma excelente uniformidade da vazão, com base no limite de tolerância do coeficiente de variação de um mesmo tipo de bico que é de $5 \%$, conforme recomendação da entidade de pesquisa Biologische Bundesanstalt Fürland-Und Forstwrts-Chaft Bundersrepublik Deutschland (1988), citada por Furlanete (1995).

O desvio médio foi obtido através da razão da diferença da vazão média e vazão nominal pela vazão nominal. Pode-se observar uma variação entre $-3,58$ a 1,93\%, amplitude essa, dentro da tolerância do controle de qualidade do fabricante do bico (Albuz Ceramiques, 1991), que aceita uma variação de vazão de $\pm 5 \%$ em relação a 
vazão nominal e da tolerància de $\pm 4,0 \%$, estipulada pela Organização Mundial da Saúde - OMS (1976).

Os bicos de cerâmica XR, apresentaram vazões, praticamente, idênticas até o trigésimo exemplar, que foram adquiridos num mesmo lote. $O$ segundo lote apresentou pequenas diferenças de vazão em relação ao primeiro.

Os exemplares 11, 14 e 33 do bico de cerâmica ADI tiveram vazões respectivamente $9,47,6,13$ e $8,64 \%$, acima da vazão média dos cinqüenta exemplares e $9,16,5,83$ e 8,33\% acima da vazão nominal do bico. Pela indicação do fabricante, um bico é considerado gasto e deve ser substituído, quando a sua vazão exceder a vazão de um bico novo em 10\% (Albuz Ceramiques, 1991), o que deixa estes exemplares muito próximo deste valor.

O bico de kematal UF apresentou o menor coeficiente de variação da vazão $(1,02 \%)$, porém, todos os valores da vazão ficaram abaixo da nominal, tendo o maior desvio médio que foi de $-3,58 \%$ em relação a vazão nominal.

Verificou-se ainda que, a soma dos desvios médios para os seis bicos foi próxima de zero $(-0,54 \%)$, o que induz que a metodologia e os aparelhos utilizados durante as medições das vazões foram adequados para este estudo. 
Tabela 1. Vazão média dos exemplares obtida através de três repetições de leitura (1/min à pressão de $276 \mathrm{kPa})$ e vazão média, coeficiente de variação $(\mathrm{CV})$, vazão nominal e desvio médio $(\%)$ dos tipos de bicos.

\begin{tabular}{|c|c|c|c|c|c|c|}
\hline Exemplares & Cerâmica XR & Cerâmica ADI & Kematal UF & Kematal LD & Aço Inox XR & Aço Inox DG \\
\hline 1 & 1,14 & 1,19 & 1,16 & 1,21 & 1,14 & 1,12 \\
\hline 2 & 1,14 & 1,18 & 1,16 & 1,18 & 1,14 & 1,12 \\
\hline 3 & 1,14 & 1,18 & 1,16 & 1,18 & 1,17 & 1,12 \\
\hline 4 & 1,14 & 1,17 & 1,15 & 1,20 & 1,14 & 1,12 \\
\hline 5 & 1,14 & 1,22 & 1,14 & 1,20 & 1,14 & 1,12 \\
\hline 6 & 1,14 & 1,18 & 1,14 & 1,18 & 1,15 & 1,12 \\
\hline 7 & 1,14 & 1,18 & 1,15 & 1,19 & 1,15 & 1.12 \\
\hline 8 & 1,14 & 1,17 & 1,16 & 1,18 & 1,15 & 1,12 \\
\hline 9 & 1,14 & 1,18 & 1,16 & 1,18 & 1,14 & 1,12 \\
\hline 10 & 1,15 & 1,18 & 1,15 & 1,17 & 1,15 & 1,12 \\
\hline 11 & 1,15 & 1,31 & 1,14 & 1,20 & 1,16 & 1,12 \\
\hline 12 & 1,15 & 1,19 & 1,16 & 1,21 & 1,16 & 1,10 \\
\hline 13 & 1,15 & 1,19 & 1,14 & 1,18 & 1,17 & 1,10 \\
\hline 14 & 1,14 & 1,27 & 1,14 & 1,20 & 1,14 & 1,12 \\
\hline 15 & 1,14 & 1,22 & 1,13 & 1,18 & 1,14 & 1,10 \\
\hline 16 & 1,14 & 1,20 & 1,14 & 1,18 & 1,14 & 1,12 \\
\hline 17 & 1,14 & 1,17 & 1,13 & 1,18 & 1,14 & 1,11 \\
\hline 18 & 1,14 & 1,20 & 1,13 & 1,16 & 1,14 & 1,12 \\
\hline 19 & 1,14 & 1,21 & 1,13 & 1,17 & 1,14 & 1,10 \\
\hline 20 & 1,14 & 1,22 & 1,13 & 1,17 & 1,17 & 1,10 \\
\hline 21 & 1,14 & 1,20 & 1,13 & 1,18 & 1,15 & 1,13 \\
\hline 22 & 1,14 & 1,20 & 1,13 & 1,18 & 1,15 & 1,10 \\
\hline 23 & 1,14 & 1,18 & 1,13 & 1,18 & 1,18 & 1,13 \\
\hline 24 & 1,14 & 1,17 & 1,13 & 1,18 & 1,15 & 1,13 \\
\hline 25 & 1,14 & 1,21 & 1,15 & 1,18 & 1,15 & 1,13 \\
\hline 26 & 1,14 & 1,17 & 1,15 & 1,18 & 1,15 & 1,09 \\
\hline 27 & 1,14 & 1,17 & 1,15 & 1,23 & 1,16 & 1,13 \\
\hline 28 & 1,14 & 1,18 & 1,14 & 1,18 & 1,15 & 1,13 \\
\hline 29 & 1,14 & 1,17 & 1,15 & 1,19 & 1,15 & 1,13 \\
\hline 30 & 1,14 & 1,17 & 1,14 & 1,18 & 1,17 & 1,13 \\
\hline 31 & 1,21 & 1,17 & 1,14 & 1,19 & 1,15 & 1,10 \\
\hline 32 & 1,19 & 1,22 & 1,14 & 1,19 & 1,17 & 1,11 \\
\hline 33 & 1,18 & 1,30 & 1,15 & 1,18 & 1,17 & 1,10 \\
\hline 34 & 1,18 & 1,20 & 1,15 & 1,18 & 1,17 & 1,13 \\
\hline 35 & 1,18 & 1,22 & 1,15 & 1,20 & 1,18 & 1,10 \\
\hline 36 & 1,18 & 1,22 & 1,14 & 1,21 & 1,18 & 1,11 \\
\hline 37 & 1,18 & 1,20 & 1,14 & 1,19 & 1,15 & 1,13 \\
\hline 38 & 1,19 & 1,23 & 1,15 & 1,19 & 1,17 & 1,11 \\
\hline 39 & 1,18 & 1,24 & 1,15 & 1,19 & 1,15 & 1,11 \\
\hline 40 & 1,18 & 1,17 & 1,15 & 1,19 & 1,15 & 1,09 \\
\hline
\end{tabular}

continua... 
continuação.

Tabela 1. Vazão média dos exemplares obtida através de três repetições de leitura $(1 /$ min à pressão de $276 \mathrm{kPa})$ e vazão média, coeficiente de variação $(\mathrm{CV})$, vazão nominal e desvio médio (\%) dos tipos de bicos.

\begin{tabular}{|c|c|c|c|c|c|c|}
\hline Exemplares & Cerâmica XR & Cerâmica ADI & Kematal UF & Kematal LD & Aço Inox XR & Aço Inox DG \\
\hline 41 & 1,19 & 1,19 & 1,15 & 1,21 & 1,15 & 1,12 \\
\hline 42 & 1,20 & 1,19 & 1,16 & 1,20 & 1,15 & 1,12 \\
\hline 43 & 1,18 & 1,20 & 1,15 & 1,21 & 1,13 & 1,14 \\
\hline 44 & 1,18 & 1,20 & 1,17 & 1,20 & 1,14 & 1,12 \\
\hline 45 & 1,17 & 1,18 & 1,16 & 1,23 & 1,14 & 1,13 \\
\hline 46 & 1,18 & 1,19 & 1,16 & 1,21 & 1,13 & 1,11 \\
\hline 47 & 1,18 & 1,16 & 1,16 & 1,22 & 1,14 & 1,12 \\
\hline 48 & 1,18 & 1,17 & 1,17 & 1,20 & 1,15 & 1,13 \\
\hline 49 & 1,19 & 1,17 & 1,17 & 1,19 & 1,14 & 1,11 \\
\hline 50 & 1,18 & 1,18 & 1,16 & 1,21 & 1,15 & 1,11 \\
\hline Média & 1,16 & 1,20 & 1,15 & 1,19 & 1,15 & 1,12 \\
\hline $\mathrm{CV}(\%)$ & 1,90 & 2,63 & 1,02 & 1,29 & 1,13 & 1,08 \\
\hline Vazão Nominal ${ }^{(a)}$ & $1,14^{(\mathrm{c})}$ & 1,20 & 1,19 & 1,17 & $1,14^{(\mathrm{c})}$ & $1,14^{(\mathrm{c})}$ \\
\hline Desvio Médio ${ }^{(\mathrm{b})}$ & 1,93 & $-0,28$ & $-3,58$ & 1,79 & 1,35 & $-1,74$ \\
\hline
\end{tabular}

(a) Valor segundo catálogo do fabricante

(b) Desvio em relação a vazão nominal, expresso em porcentagem desta

(c) Valores estimados por equação devido a vazão nominal ser referente a pressão de 3 bar (43.50 psi) 


\subsection{Avaliação dos ensaios no pré-teste}

Nos ensaios denominados de pré-teste foram estudados o comportamento do aumento porcentual da vazão dos bicos, sob a ação de diferentes caudas abrasivas. Para tanto, efetuou-se a aplicação do teste de Tukey ao nivel de 5\% para discriminar possíveis diferenças de médias entre bicos nos diversos intervalos de medições (horas), para cada um dos abrasivos. Os valores desse aumento foram analisados, tanto para cada abrasivo nos diferentes bicos, quanto para cada bico nos diferentes abrasivos, além de uma comparação relativa entre os aumentos porcentuais da vazão dos bicos, para cada abrasivo estudado

\subsubsection{Análise do aumento porcentual da vazão dos bicos sob a ação abrasiva}

As Tabelas 2 a 10 mostram as médias do aumento porcentual da vazão, de três repetições (exemplares), para os diferentes bicos, sujeitos ao desgaste acelerado em função do tempo, para os diferentes abrasivos estudados, sendo aplicado o teste de Tukey ao nivel de $5 \%$ de probabilidade. Os dados originais do aumento da vazão dos bicos em $1 /$ min encontram-se nos apêndices 1 a 9 .

Para o abrasivo Coríndon - grão 800 (Tabela 2), as médias de aumento de vazão para os bicos aço inox $\mathrm{XR}$ e aço inox $\mathrm{DG}$, de um modo geral, foram as maiores $\mathrm{e}$ diferenciaram entre si ao longo de todo o tempo. Isso permite afirmar que os bicos confeccionados com este material sofreram maior desgaste em relação aos demais, porém o bico aço inox XR mostrou suas médias excessivamente superiores as do aço inox DG, tendo este último, suas médias não tão distantes dos demais bicos. Já as médias dos bicos de cerâmica XR e ADI, apresentaram as menores variações em relação as suas 
respectivas vazões iniciais, não apresentando também diferenças significativas entre si, sendo estes, portanto, os mais resistentes sob a ação deste abrasivo. Os bicos confeccionados em kematal apresentaram diferenças significativas entre suas médias, sendo que o bico de kematal UF teve suas médias inferiores ao de kematal LD. Os dados obtidos com este abrasivo com respeito ao tempo para atingir determinados niveis de desgaste, diferiram completamente dos resultados publicados por Gandolfo (1995). O que pode ser explicado pela grande diferença do tamanho da granulometria dos materiais abrasivos.

$\mathrm{O}$ bico de aço inox XR, quando sob a ação do abrasivo Carbeto de Silicio - SIC 800 (Tabela 3), apresentou comportamento semelhante ao abrasivo anterior, tendo média muito superior em relação aos demais. Os bicos de cerâmica não apresentaram diferenças significativas até o limite de quatro horas de uso, sendo significativas a partir deste limite. Os bicos de kematal foram significativos até vinte horas de teste, não apresentando diferenças significativas nas medições de vinte e trinta horas, e voltando a ser significativas a partir desta última medição. $O$ aço inox DG teve suas médias diferindo, significativamente, dos demais até quatro horas e após vinte e cinco horas, chegando a cinqüenta horas com média intermediária entre as dos bicos de cerâmica XR e de kematal LD, apresentando, portanto, para este abrasivo, uma resistência ao desgaste superior aos bicos de kematal.

O produto Caulim O.B. 2150 (Tabela 4) demonstrou ter ação pouco abrasiva, não elevando a vazão a níveis tão altos, quanto aos anteriores. Os bicos de cerâmica XR e ADI tiveram as menores médias, não diferindo significativamente entre si ao longo de todo teste. O bico de kematal UF apresentou diminuição da vazão média nas primeiras horas, chegando a atingir $-4,88 \%$ com quatro horas de teste, tendo após isso, aumentos constantes, chegando ao final do teste com $12,36 \%$, que foi uma das maiores médias, sendo superado apenas pela média do bico de aço inox XR que foi de $15,45 \%$. Os dados obtidos com este abrasivo foram semelhantes aos obtidos por Ozkan et al.(1991); Reichard et al.(1991); Zhu et al.(1995). 

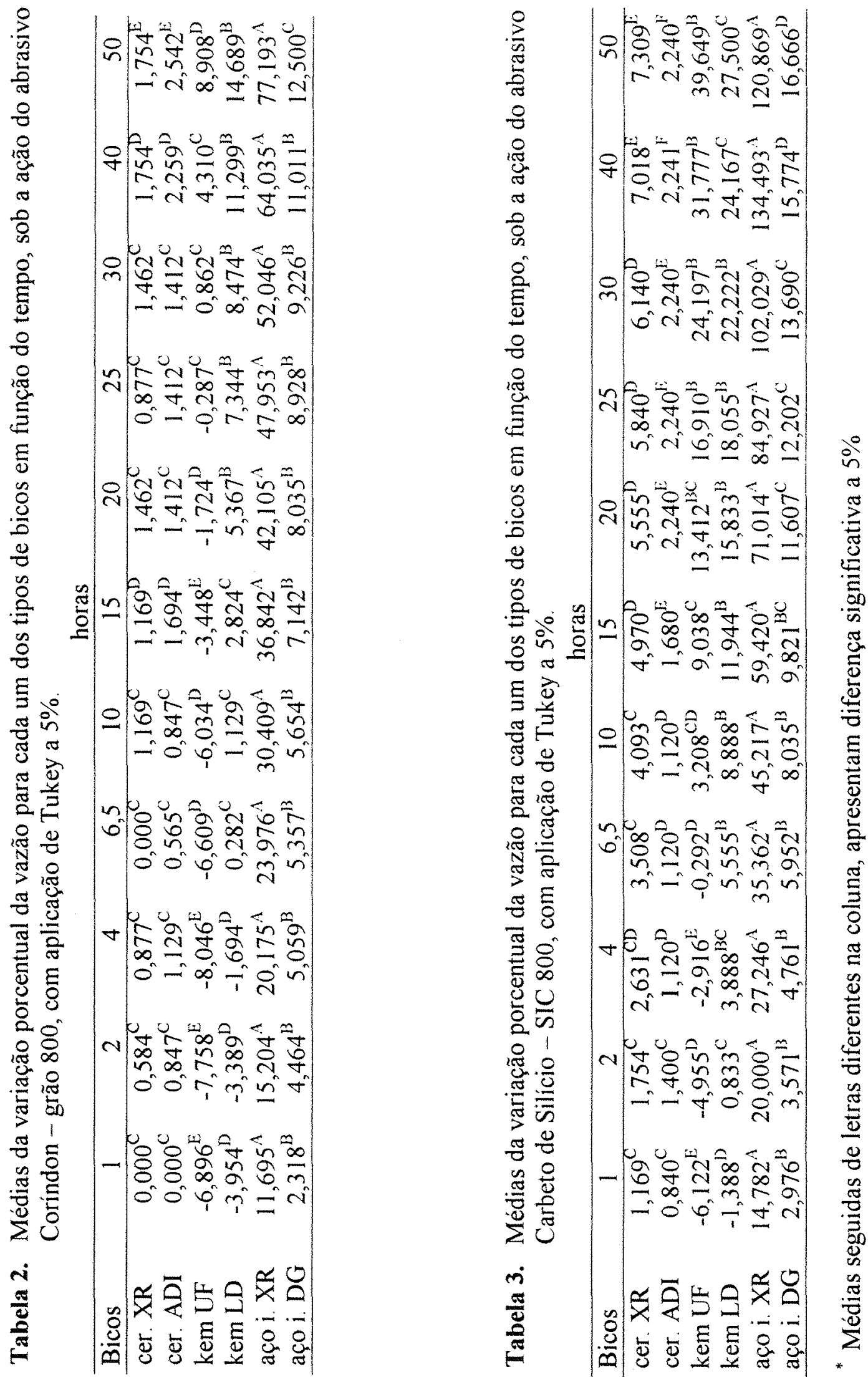

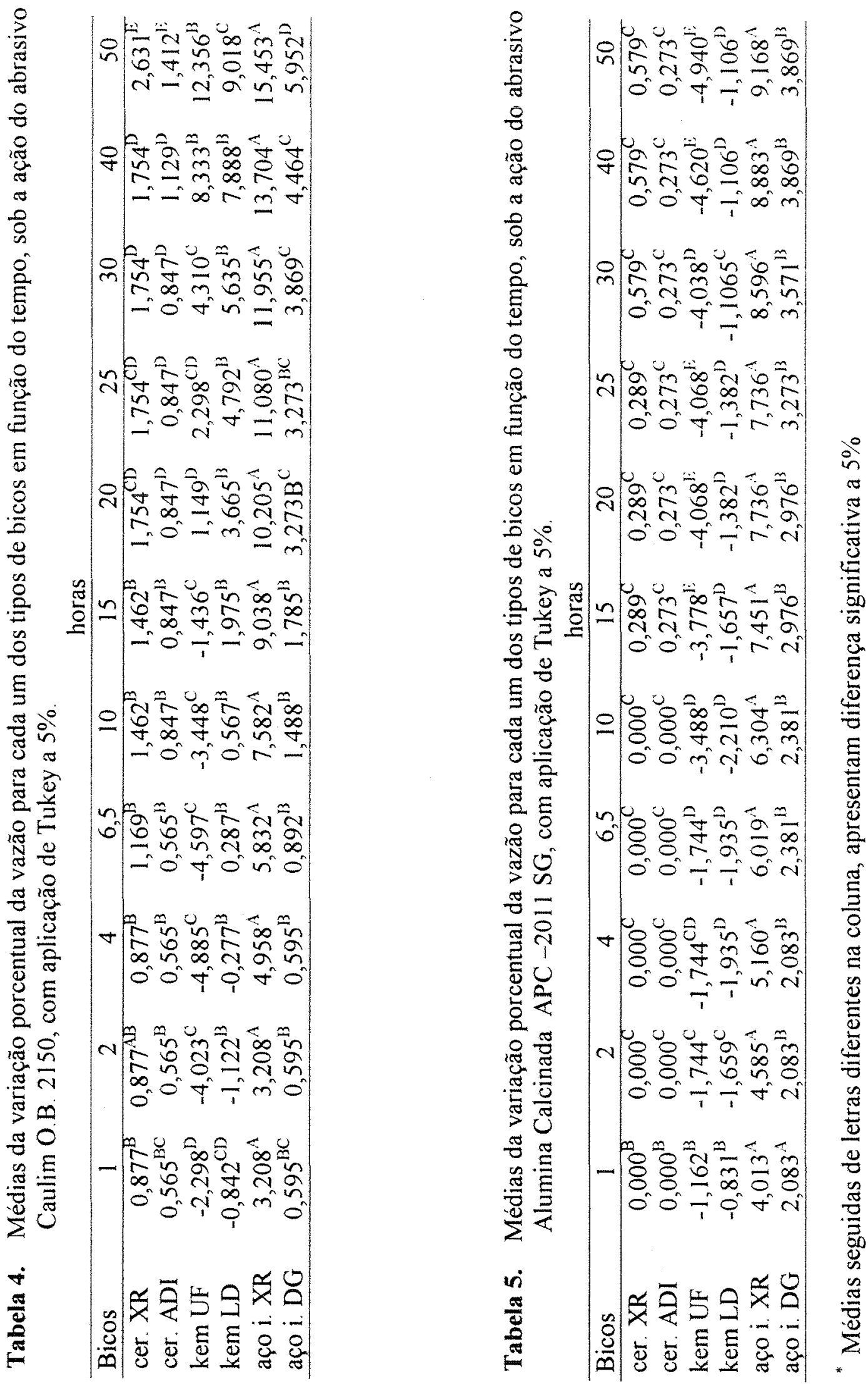


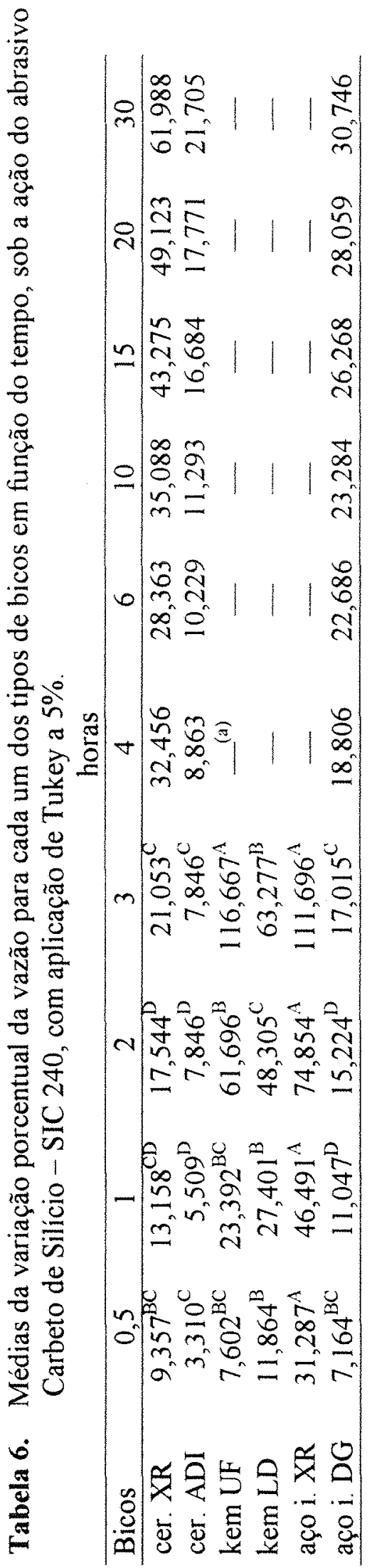

$\frac{\sqrt{2}}{2}$

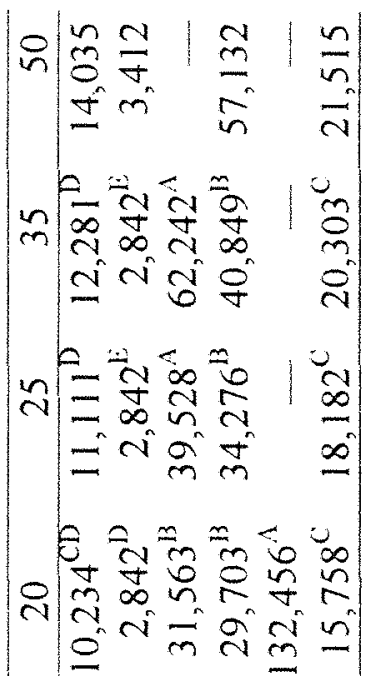

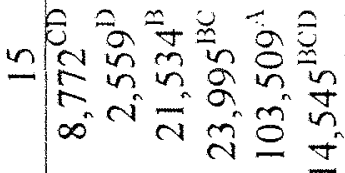

in

$\frac{2}{8}$

8

ڤ

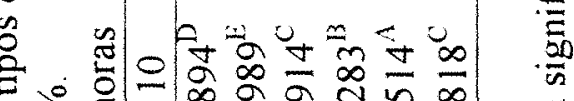

o i

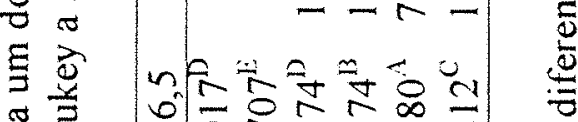

ग

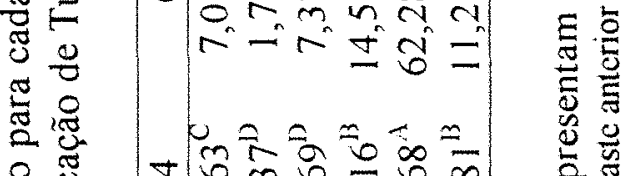

0 ت

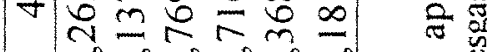

焉:

ग ह

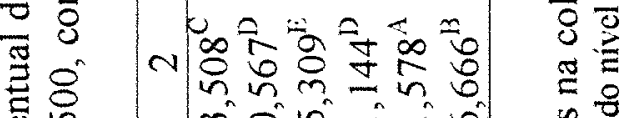

总

造行

茷

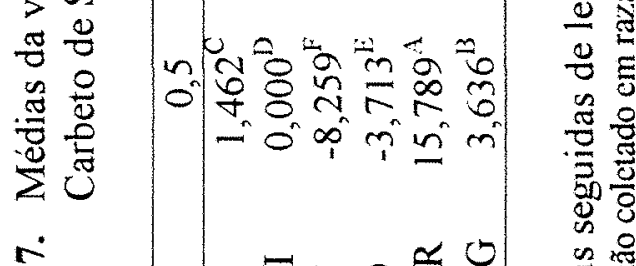

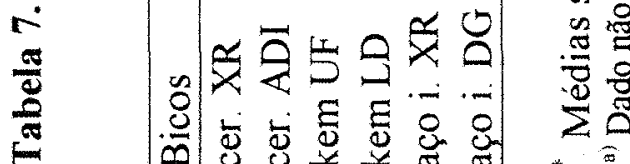



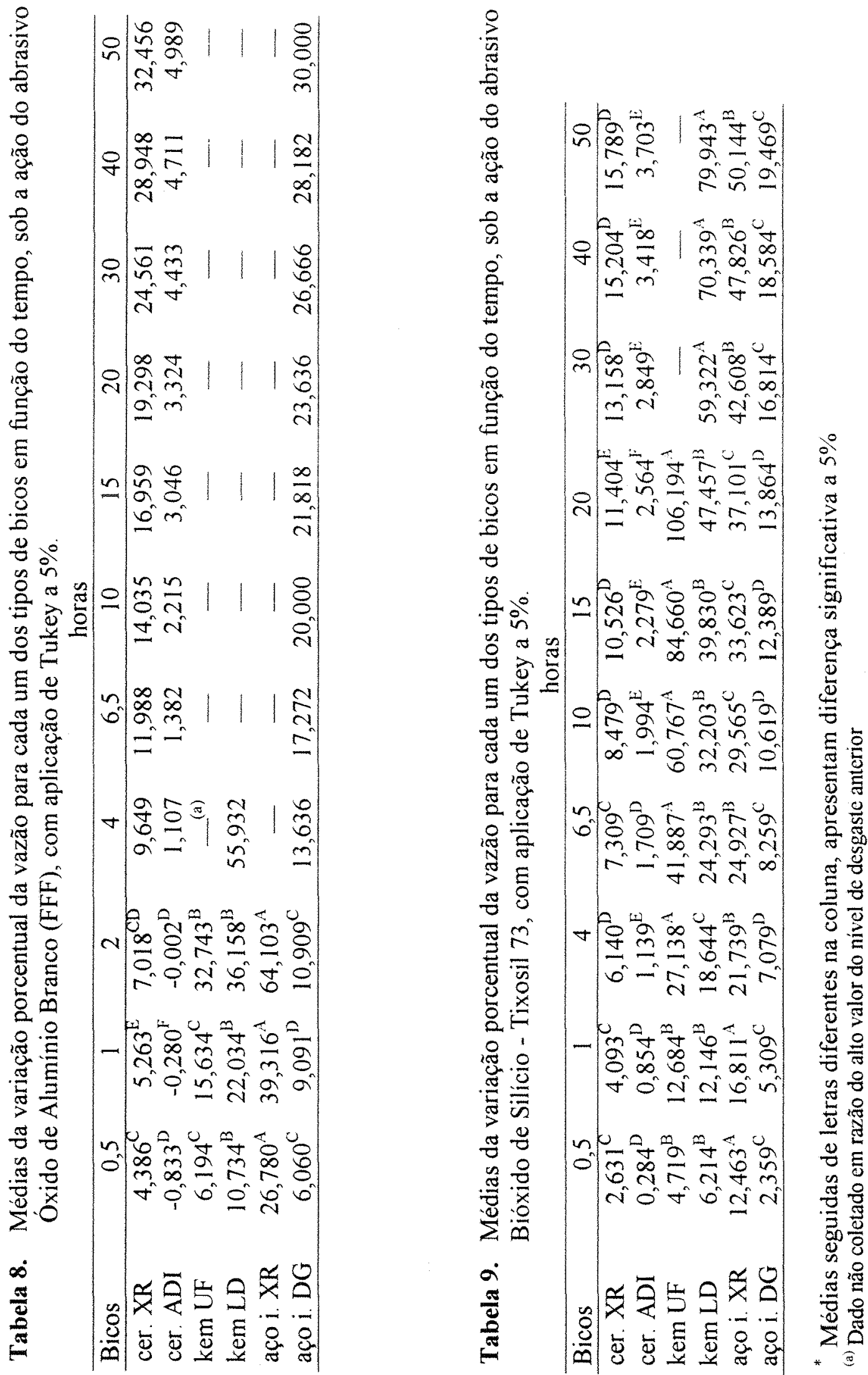


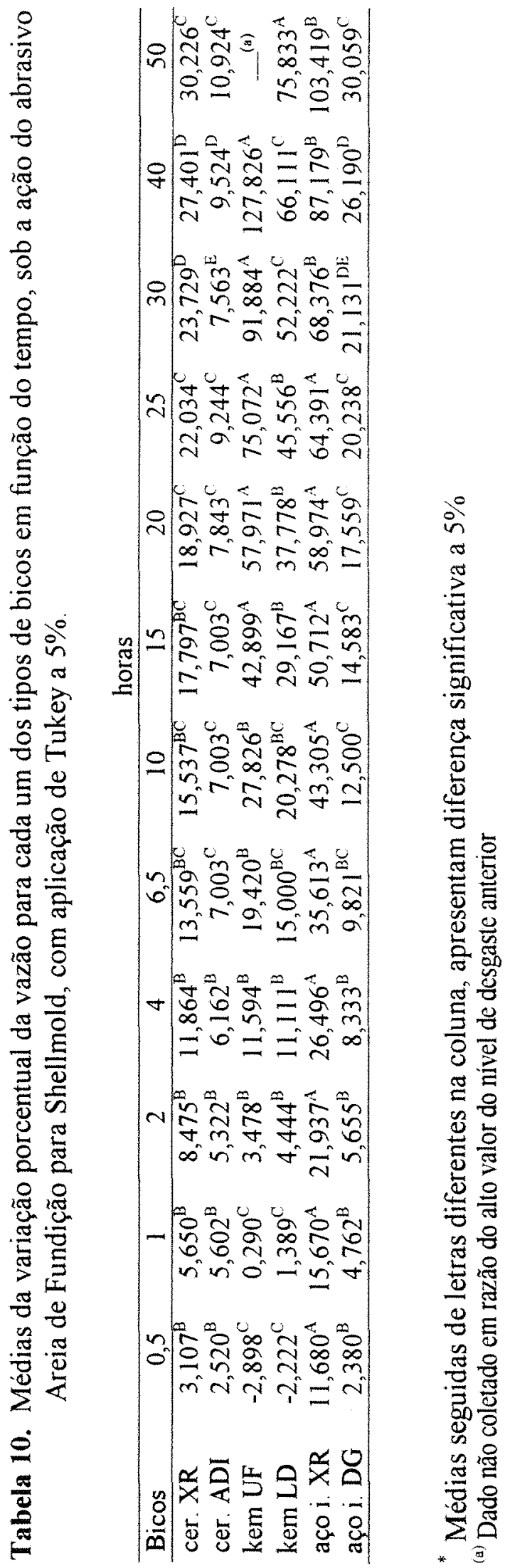


As médias obtidas no teste com o abrasivo Alumina Calcinada - APC 2011 SG (Tabela 5), foram as menores quando comparadas às médias dos demais abrasivos. Os bicos de kematal UF e LD apresentaram valores negativos ao longo de todo tempo diferindo, significativamente, entre si após quinze horas de teste, atingindo no final do teste as médias de $-4,94 \mathrm{e}-1,12 \%$, respectivamente. Os bicos de aço inox XR e DG apresentaram um brusco aumento da vazão, já na primeira hora de teste, que corresponde a 4,01 e 2,08\%, respectivamente, sendo que, após isso, as diferenças desses aumentos não foram tão acentuadas, apesar de significativas entre si.

Para o abrasivo Carbeto de Silíco - SIC 240 (Tabela 6), o teste foi interrompido com três horas para os bicos de aço inox XR e de kematal UF e LD, devido terem atingido altos valores porcentuais da vazão, ultrapassando os limites indicados pela Norma NBR 13769 (1997), a qual estipula que em testes de desgaste acelerado deve-se elevar o nível de desgaste em até 50\%. Em virtude disso, após quatro horas de teste não foi aplicado o teste de Tukey, pois o número de tratamentos restantes não garantiu os graus de liberdade suficientes para confiabilidade das comparações. Os bicos de aço inox DG e os de cerâmica XR e $\mathrm{ADI}$, não apresentaram diferença significativa até as três horas analisadas. Para o bico de aço inox $X R$, observam-se médias significativamente maiores que as dos bicos de kematal UF e LD até duas horas de teste, sendo que na terceira hora não apresentou diferença significativa em relação ao bico de kematal UF.

$\mathrm{Na}$ Tabela 7 estão apresentadas as médias referentes ao abrasivo Carbeto de Silício - SIC 500 onde, observa-se que não foi aplicado o teste de Tukey no tempo de cinquienta horas, devido este não apresentar todos os tratamentos (bicos), o que implica num baixo grau de liberdade para o teste. $\mathrm{O}$ bico de aço inox $\mathrm{XR}$ apresentou médias significativamente superiores aos demais ao longo de todo o teste. $O$ teste para o bico de aço inox XR foi interrompido as vinte horas, quando este atingiu $132,45 \%$ de aumento de vazão. Os demais bicos, após vinte e cinco horas de teste, mostraram diferenças significativas entre si, o que indica um comportamento diferenciado do aumento da vazão dos bicos para o abrasivo em questão. 
À Semelhança do ocorrido no teste com o abrasivo Carbeto de Silicio SIC 240, para o abrasivo Óxido de Aluminio Branco (FFF) (Tabela 8), o teste foi interrompido com quatro horas, para os bicos de kematal UF e de aço inox XR e com seis horas e meia para o bico de kematal LD. Com isto, aplicou-se o teste de Tukey apenas nas medições de meia, uma e duas horas. Sendo assim, as médias dessas medições não são representativas para uma análise de comparação, visto que este tempo representou apenas $4 \%$ de todo o teste, que foi de 50 horas. As possiveis análises referentes a este abrasivo, são realizadas através da discussão dos resultados mostrados graficamente.

Pela análise da Tabela 9 relativa ao abrasivo Tixosil 73 , observa-se que as médias do aumento porcentual do bicos de cerâmica XR e aço inox DG, não diferiram, significativamente, até quinze horas, sendo que a partir deste tempo todos os demais bicos apresentaram diferenças significativas entre suas médias, mostrando grande dispersão entre estas, o que indica um comportamento diferenciado do aumento da vazão dos bicos para o abrasivo em questão.

As médias do teste com o abrasivo Areia de Fundição estão apresentadas na Tabela 10. Observa-se que para os bicos de cerâmica XR e aço inox DG, as médias não tiveram diferença significativa entre si ao longo de todo teste. Outras análises sobre este abrasivo foram feitas com base na Tabela 11, que mostra as variâncias médias dos bicos por tempo, para cada abrasivo, onde verifica-se que, para a Areia de Fundição, as variâncias são crescentes e com valores muito superiores aos dos demais, com exceção do abrasivo Carbeto de Silício - SIC 240.

Os altos valores da variância para os abrasivos Areia de Fundição e Carbeto de Silício - SIC 240 prejudicaram as avaliações, não só dos resultados da análise de variância e do teste de Tukey mas, também, da estimativa da média, com a qual foram construidos os gráficos, pois esta passa a ter baixa confiabilidade. Nota-se ainda, que os altos valores da variância estão relacionados aos abrasivos de maior granulometria, o que indica que estes provocam desgaste desuniforme nos exemplares (repetições) de um mesmo tipo bico, permitindo afirmar que a variação dos aumentos porcentuais entre as 
repetições são maiores na medida que utiliza-se abrasivos de maior granulometria. Por este motivo, o objetivo deste trabalho é avaliar outros abrasivos de menor granulometria, para uso em testes de desgaste acelerado de bicos pulverizadores.

Tabela 11. Variâncias médias dos aumentos porcentuais da vazão dos bicos por tempo para cada um dos abrasivos.

\begin{tabular}{crrrrrrrrr}
\hline Tempos & Corindon & SIC-800 & Caulim & Alumina & SIC-240 & SIC-500 & FFF & Tixosil 73 & Areia \\
\hline 0,5 & - & - & - & - & 7,25 & 0,12 & 1,16 & - & 1,19 \\
1 & 0,60 & 0,25 & 0,28 & 0,51 & 15,56 & 0,21 & 1,71 & 0,34 & 2,42 \\
2 & 0,57 & 0,21 & 0,82 & 0,47 & 22,19 & 0,39 & 10,53 & 0,30 & 3,43 \\
4 & 0,73 & 0,57 & 0,45 & 0,48 & 2,53 & 0,36 & 3,23 & 0,33 & 6,63 \\
6,5 & 0,77 & 0,34 & 0,68 & 0,35 & - & 0,48 & 0,90 & 0,59 & 12,69 \\
10 & 0,41 & 0,69 & 0,41 & 0,26 & 5,75 & 0,87 & 1,12 & 0,86 & 24,07 \\
15 & 0,32 & 0,81 & 0,41 & 0,33 & 30,07 & 3,19 & 0,16 & 0,50 & 19,11 \\
20 & 0,97 & 0,81 & 0,42 & 0,32 & 32,20 & 3,82 & 1,03 & 0,73 & 29,35 \\
25 & 0,64 & 0,91 & 0,66 & 0,32 & - & 2,04 & - & 0,62 & 31,35 \\
30 & 0,41 & 1,11 & 0,14 & 0,41 & 57,80 & - & 1,47 & - & 25,06 \\
40 & 0,49 & 2,40 & 0,44 & 0,24 & - & 2,44 & 3,69 & 0,19 & 46,59 \\
50 & 0,32 & 1,35 & 0,85 & 0,24 & - & 2,80 & 4,14 & 0,15 & 54,45 \\
\hline Médias & 0,57 & 0,86 & 0,51 & 0,36 & 21,66 & 1,52 & 2,65 & 0,46 & 21,40 \\
\hline
\end{tabular}

De modo geral, para a maioria dos abrasivos estudados, os bicos de uso ampliado (XR e UF) apresentaram as maiores médias em relação aos de baixa deriva (ADI, LD e DG) do mesmo material, indicando, portanto, que a resistência ao desgaste não está apenas em função do material de confecção do bico, mas também, do tipo de atuação deste, isto é, de uso ampliado ou de baixa deriva. 


\subsubsection{Análise dos bicos por abrasivo}

Através das Figuras 12 a 20 observa-se que os aumentos das vazões foram na maioria da vezes crescente, com exceção dos bicos confeccionados em kematal, que tiveram suas vazões diminuidas nas primeiras horas do teste. Richard et al. (1991), também observaram estes efeitos para os bicos de plástico, porém não justificaram o motivo deste decréscimo. Já Matthews \& Thronhill (1996), explicam que bicos confeccionados em plástico, absorvem água afetando a vazão, pela mudança no tamanho do orificio.

Todas as equações de regressão (Tabela 12) tiveram altos valores de $r^{2}$, observando-se um excelente ajuste da equação aos dados, o que indica estarem explicando grande parte do comportamento do aumento da vazão do bico em função do tempo no intervalo medido. Para a grande maioria dos bicos, nos diversos abrasivos, a equação de melhor ajuste foi a de segundo grau, em razão de uma leve inclinação das linhas, resultante da alteração do aumento da vazão ser mais acentuada nas primeiras horas de teste. Este efeito já era esperado, uma vez que vários autores têm reportado situações semelhantes (Corrêa \& Lorena Neto, 1976; Bode et al., 1984).

Para o abrasivo Coríndon - grão 800 (Figura 12 ) o bico de aço inox XR apresentou uma grande disparidade no aumento da vazão em função do tempo em relação aos demais bicos testados. O bico de kematal UF teve sua vazão diminuída, atingindo $-8,04 \%$ nas primeiras quatro horas, voltando à vazão inicial aproximadamente com vinte e sete horas, e apresentando $8,9 \%$ de aumento da vazão com cinqüenta horas de teste. Resultado este muito próximo do obtido pela Albuz Ceramiques (1991). Após cinqüenta horas de teste a ordem decrescente de durabilidade foi : cer. $\mathrm{Xr}$, cer. ADI, kem UF, aço i. DG, kem LD e aço i. XR. 


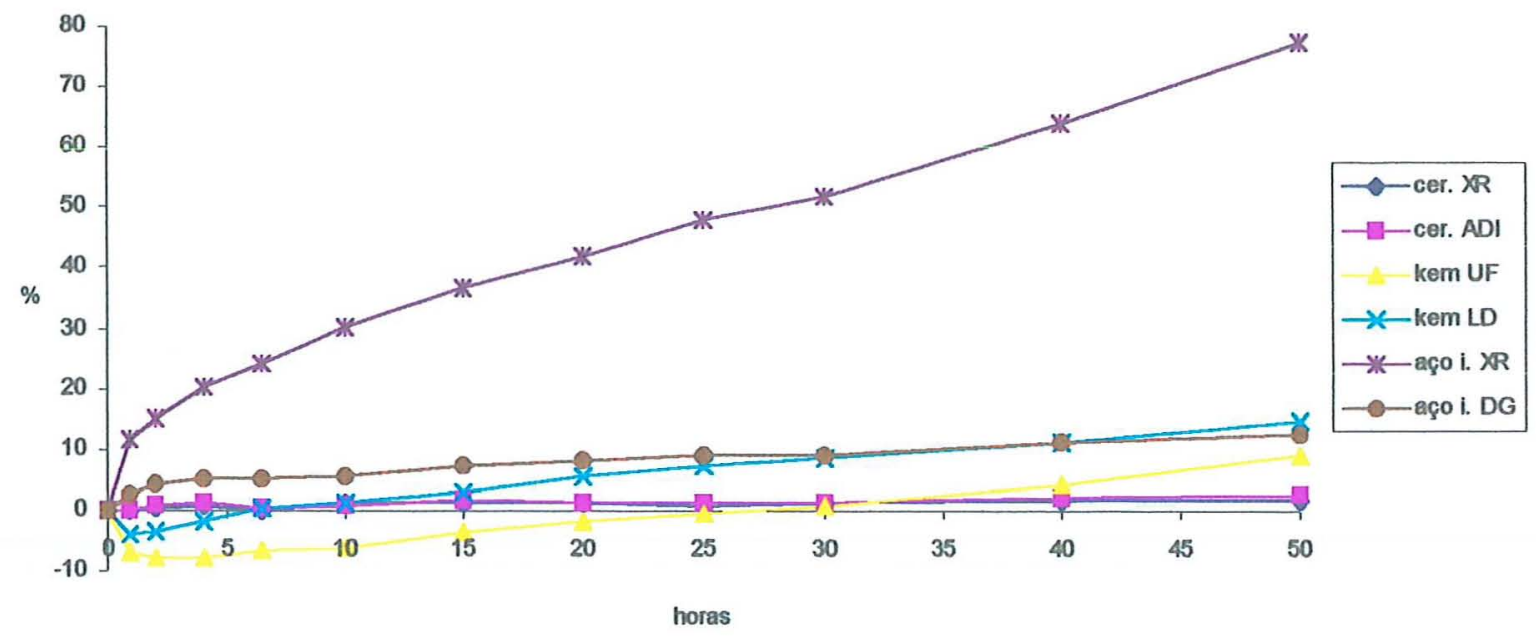

Figura 12. Gráfico do aumento porcentual da vazão em função do tempo sob a ação do abrasivo Coríndon - grão 800

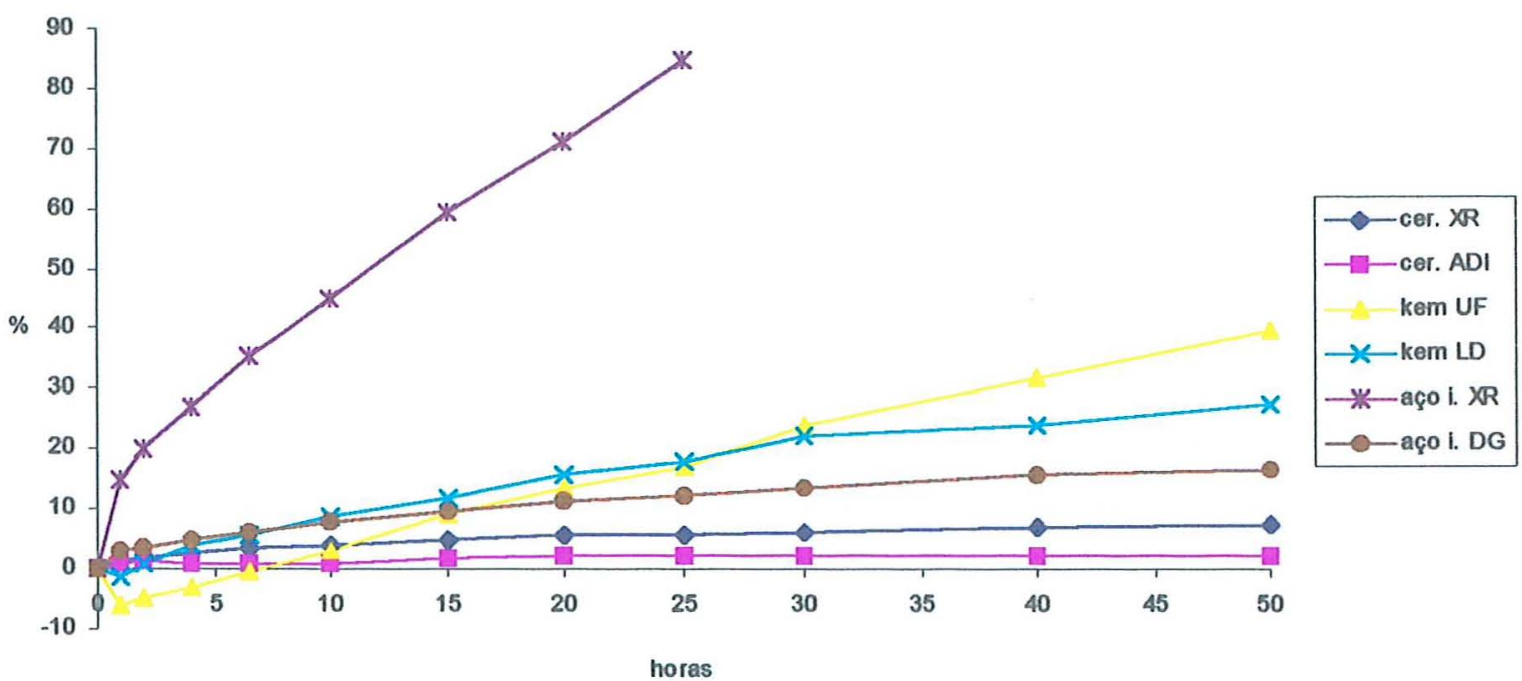

Figura 13. Gráfico do aumento porcentual da vazão em função do tempo sob a ação do abrasivo Carbeto de Silício - SIC 800 


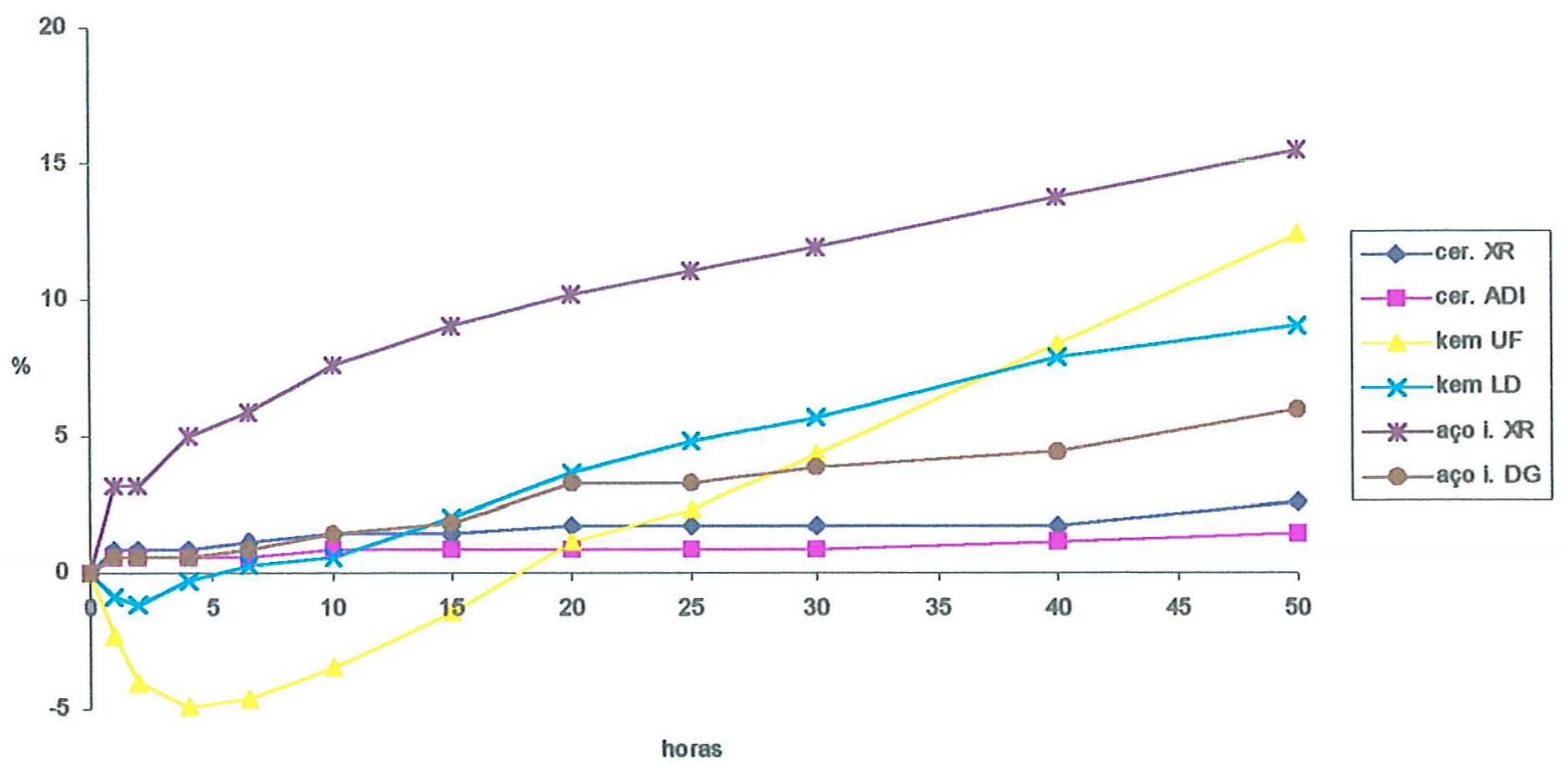

Figura 14. Gráfico do aumento percentual da vazão em função do tempo sob a ação do abrasivo Caulim O. B. 2150

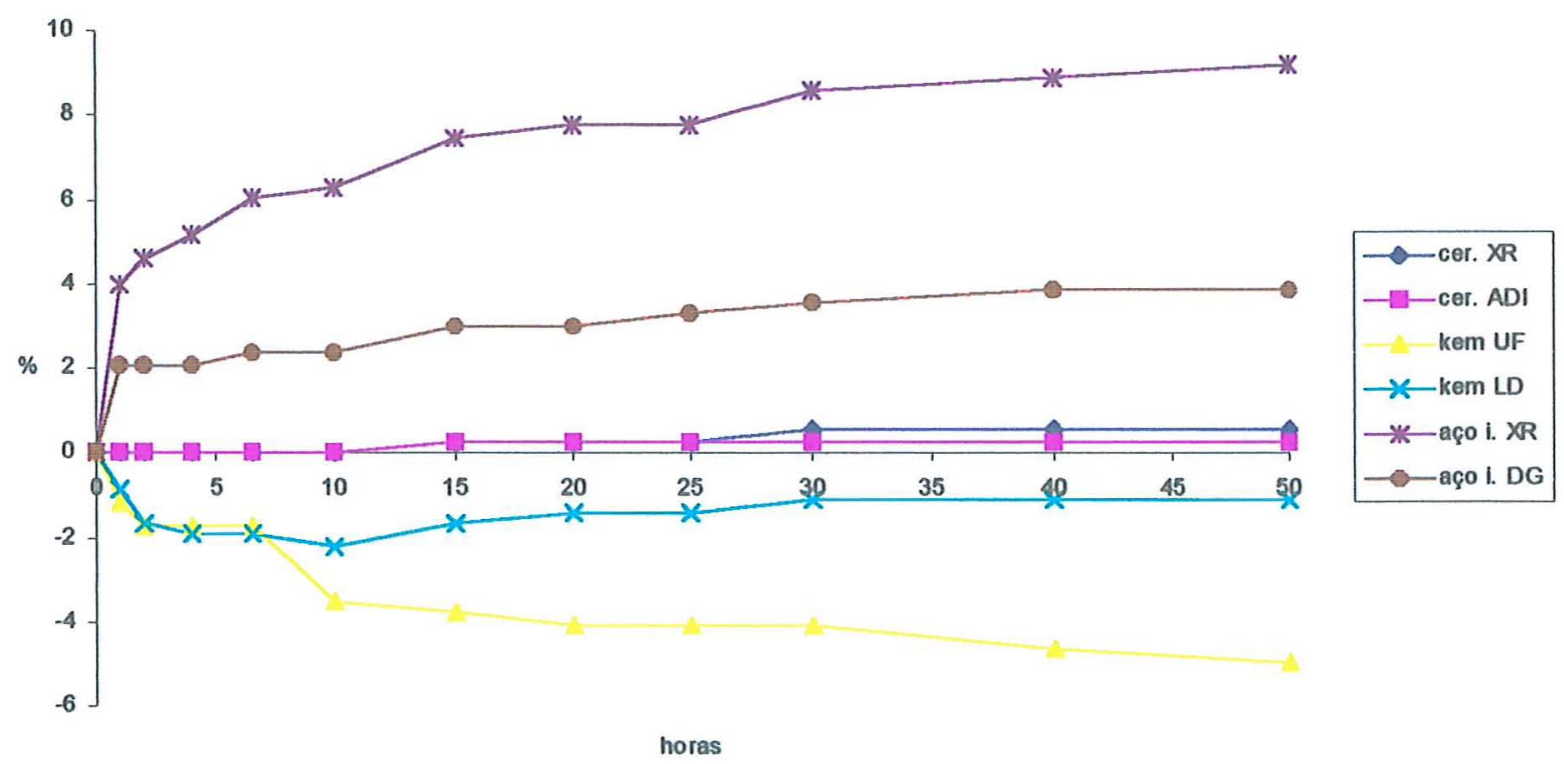

Figura 15. Gráfico do aumento percentual da vazão em função do tempo sob a ação do abrasivo Alumina Calcinada APC 2011 SG 


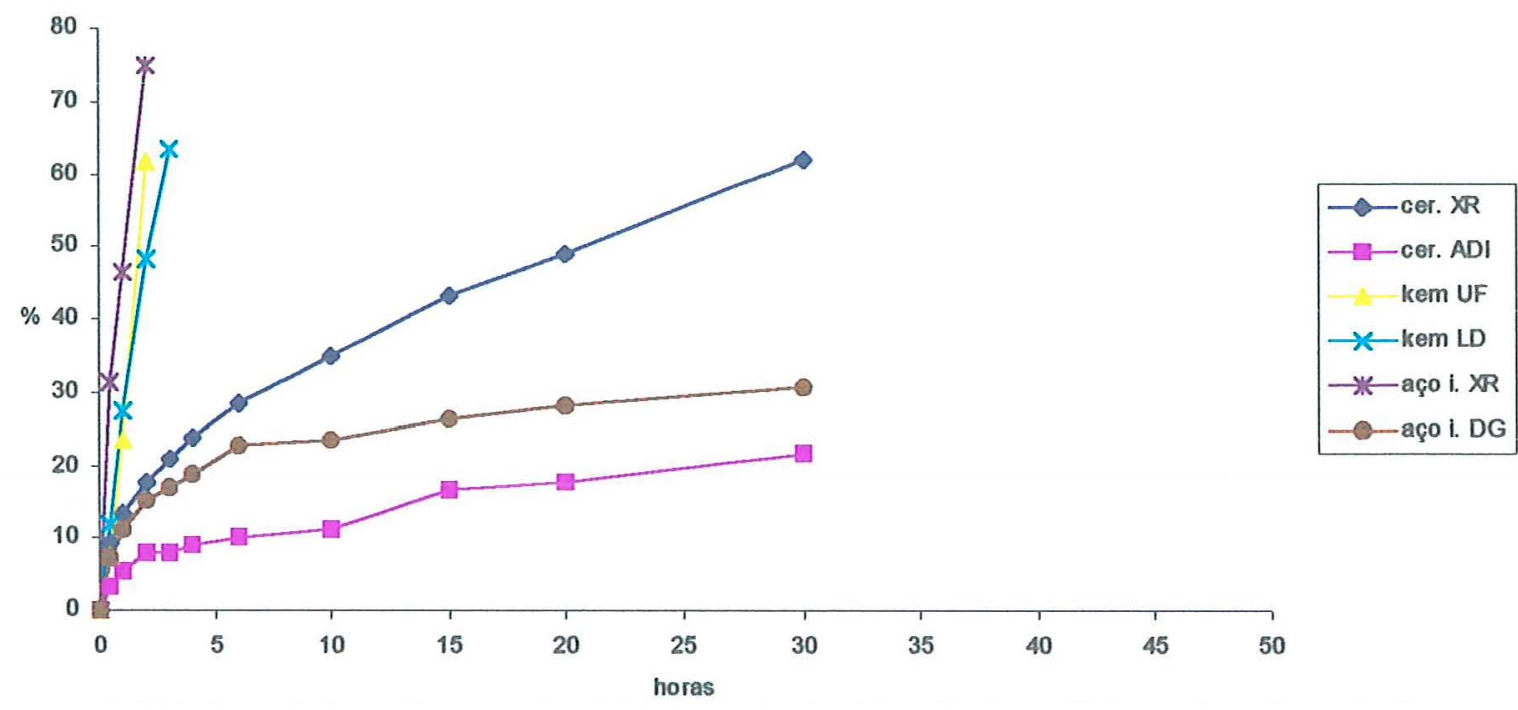

Figura 16. Gráfico do aumento porcentual da vazão em função do tempo sob a ação do abrasivo Carbeto de Silíco - SIC 240

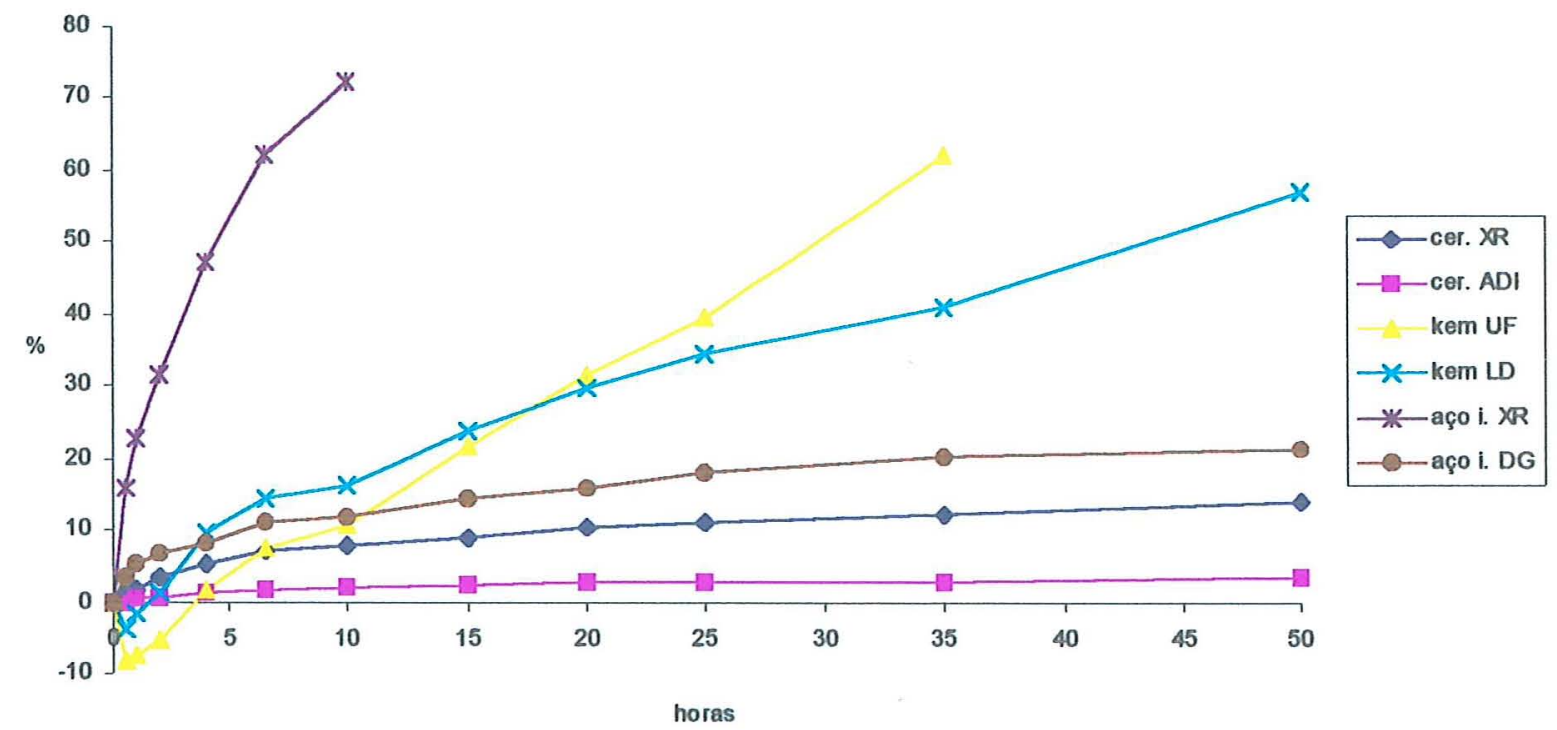

Figura 17. Gráfico do aumento porcentual da vazão em função do tempo sob a ação do abrasivo Carbeto de Silíco - SIC 500 


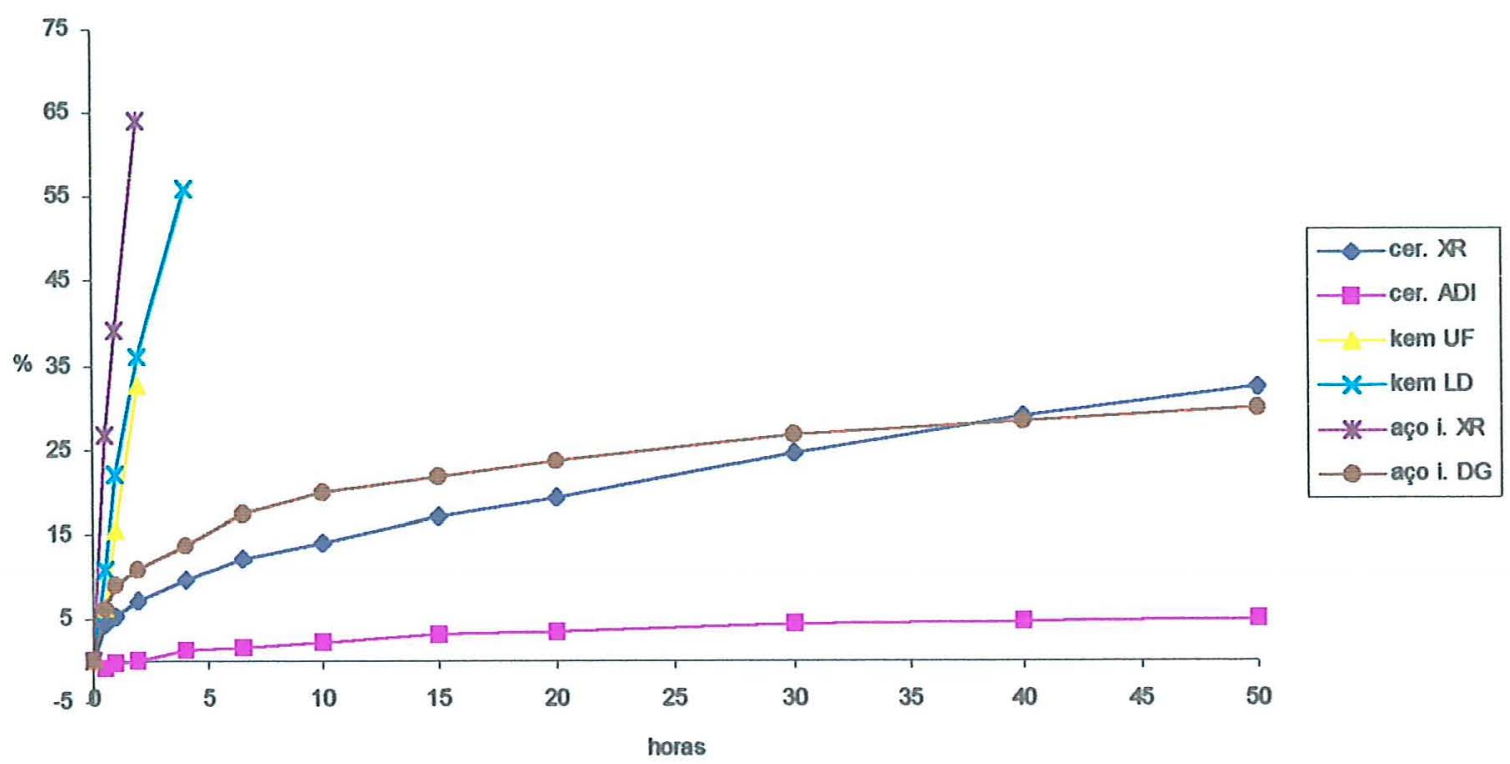

Figura 18. Gráfico do aumento porcentual da vazão em função do tempo sob a ação do abrasivo Óxido de Alumínio Branco (FFF)

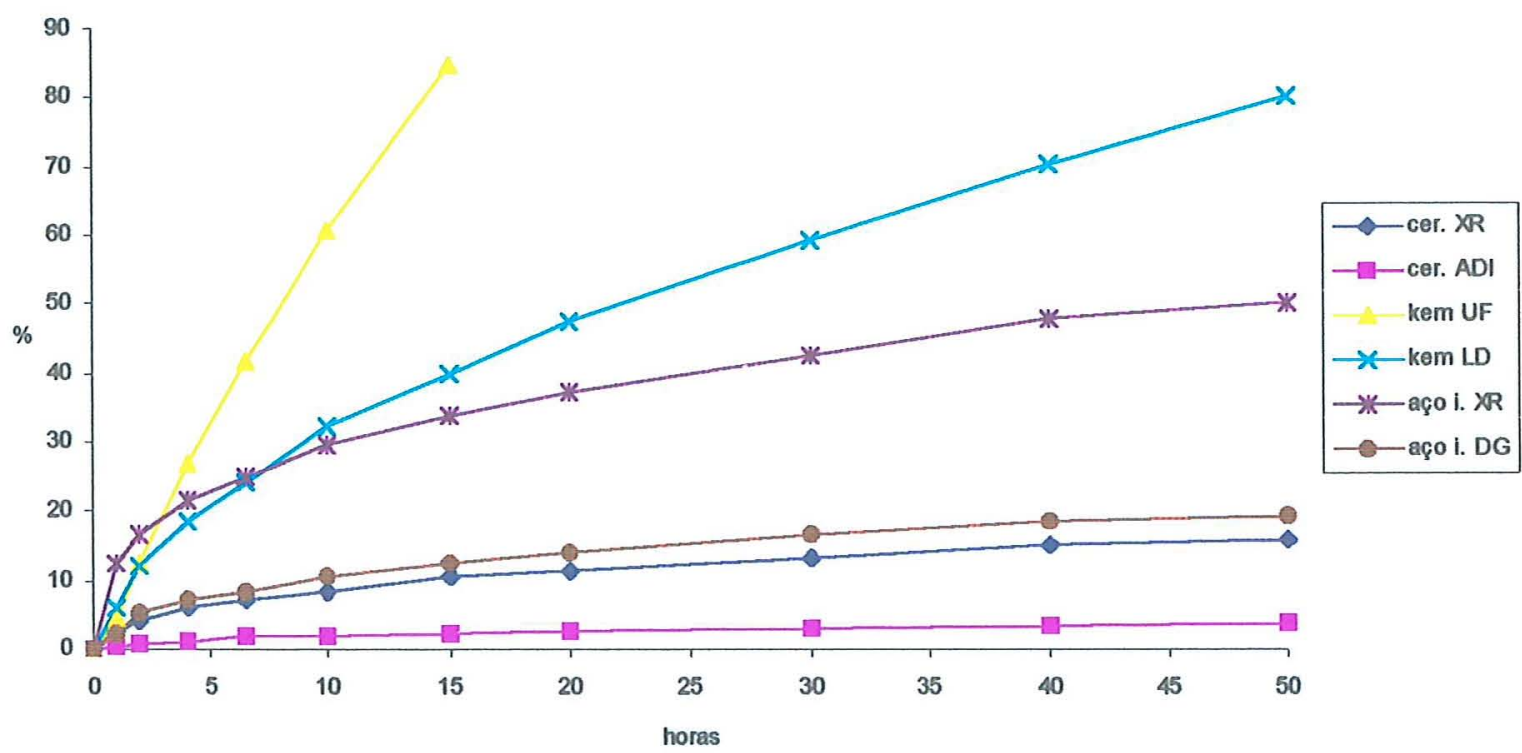

Figura 19. Gráfico do aumento porcentual da vazão em função do tempo sob a ação do abrasivo Bióxido de Silício - Tixosil 73 


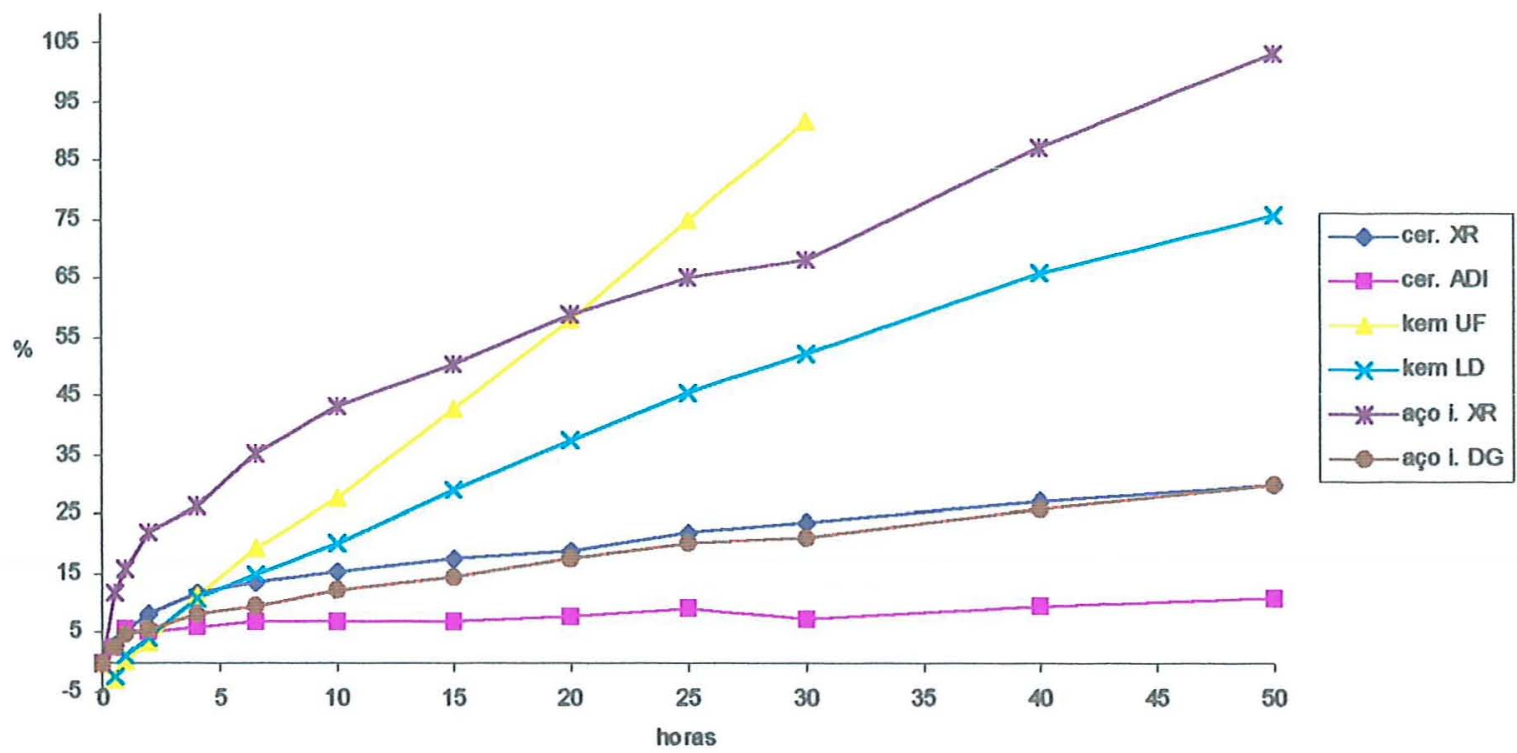

Figura 20. Gráfico do aumento porcentual da vazão em função do tempo sob a ação do abrasivo Areia de Fundição para Shellmold 
À semelhança do ocorrido no abrasivo anterior, o bico de aço inox XR, para o abrasivo Carbeto de Silício - SIC 800 (Figura 13), apresentou também uma grande diferença no aumento da vazão em relação aos demais bicos. O cerâmica ADI teve pequenos acréscimos da vazão até vinte horas de teste, estabilizando após isto com $2,24 \%$. O bico de kematal LD inicialmente apresentou maior desgaste em relação ao seu semelhante de kematal UF, invertendo essa situação com aproximadamente vinte e sete horas. Para esse abrasivo a ordem decrescente de durabilidade, após cinqüenta horas de teste foi : cer. ADI, cer. XR, aço i. DG, kem LD, kem UF e aço i. XR

No teste utilizando-se o abrasivo Caulim O.B. 2150 (Figura 14), o bico aço i. XR apresentou maior desgaste, porém, não demonstrou grande disparidade em relação aos demais. Os bicos de kematal UF e LD tiveram diminuição da vazão até o limite de $-4,6 \%$ com 6,5 horas e $-1,12 \%$ com 2 horas, respectivamente, antes desta começar a aumentar, observando que, o primeiro bico apresenta sempre maiores diminuições na vazão, que o segundo. A ordem decrescente de durabilidade ao final do teste foi idêntica a do abrasivo anterior.

Nos resultados do teste com o abrasivo Alumina Calcinada - APC 2011 SG (Figura 15), verifica-se uma dificuldade de indicar a ordem de durabilidade dos bicos, pois os de kematal mantiveram valores negativos da vazão, até o final do teste, induzindo, assim, que teriam maior durabilidade que os demais. Os bicos de cerâmica $\mathrm{XR}$ e ADI, praticamente não apresentaram desgaste, chegando ao final do teste com aumentos percentuais na vazão de 0,58 e $0,27 \%$, respectivamente. $\mathrm{O}$ bico aço inox $X R$ foi o que apresentou maior desgaste, porém não tão elevado como vinha ocorrendo nos abrasivos anteriores.

Para o abrasivo Carbeto de Silício - SIC 240 (Figura 16) o bico de aço inox $\mathrm{XR}$ e os bicos de kematal UF e LD tiveram o teste interrompido nas primeiras horas, devido terem atingido altos valores porcentuais de vazão, ultrapassando os limites indicados pela Norma NBR 13769 (1997), que estipula níveis de desgaste de até 50\%. O bico de cerâmica XR sofreu considerável aumento da vazão, chegando a $62 \%$ com trinta 
Tabela 12. Equações de regressão para cada um dos seis bicos testados sob a ação dos diferentes abrasivos, relacionando o aumento da vazão $(Y)$ em porcentagem $\mathrm{e}$ o tempo $(\mathrm{X})$ em horas.

\begin{tabular}{|c|c|c|c|}
\hline ABR ASIVOS & BICOS & EQUACOES & $t^{2(3)}$ \\
\hline \multirow{6}{*}{$\begin{array}{l}\text { Corindon } \\
\text { grào } 800\end{array}$} & or. XR & $-0.0007 x^{2}+0.0641 x-0.1993$ & 0.7444 \\
\hline & cer. $A D I$ & $-0.0003 x^{2}+0.0578 x-0.3685$ & 0.8144 \\
\hline & kem UF & $0.0047 x^{2}+0.0697 x-5.9282$ & 0.8304 \\
\hline & kem LD & $-0.0015 x^{2}+0.4215 x-2.8382$ & 0.9651 \\
\hline & $a \varphi ̧ i_{1} . X R$ & $-0.0117 x^{2}+1.8867 x-9.37$ & 0.9732 \\
\hline & aco i. DG & $-0.003 x^{2}+0.3404 x-2.4693$ & 0.9190 \\
\hline \multirow{6}{*}{$\begin{array}{l}\text { Carbeto de Silicio } \\
\text { SIC } 800\end{array}$} & er. XR & $-0.0035 x^{2}+0.2925 x-1.0712$ & 0.9560 \\
\hline & cer. ADI & $-0.0013 x^{2}+0.0947 x-0.6143$ & 0.8348 \\
\hline & kem UF & $-0.0003 x^{2}+0.9287 x-5.2511$ & 0.9833 \\
\hline & kem LD & $-0.0089 x^{2}+1.0039 x-0.8003$ & 0.9939 \\
\hline & aço i. XR & $-0.0352 x^{2}-4.1897 x-7.3946$ & 0.9765 \\
\hline & aço i. DG & $-0.0061 x^{2}+0.5939 x-1.9672$ & 0.9798 \\
\hline \multirow{6}{*}{$\begin{array}{l}\text { Caulim } \\
\text { O.B. } 2150\end{array}$} & er. XR & $0.0005 x^{2}+0.0582 x-0.6393$ & 0.8119 \\
\hline & cer. ADI & $-0.0001 x^{2}-0.0233 x-0.4139$ & 0.7698 \\
\hline & kem UF & $0.0051 x^{2}-0.0733 x-3.3414$ & 0.9220 \\
\hline & kem LD & $-0.005 x^{2}-0.2364 x-1.0837$ & 0.9816 \\
\hline & aço I.XR & $-0.0049 x^{2}+0.4963 x-2.2145$ & 0.9640 \\
\hline & aç i. DG & $-0.0005 x^{2}-0.1349 x-0.1911$ & 0.9802 \\
\hline \multirow{6}{*}{$\begin{array}{l}\text { Alumina Calcinada } \\
\text { APC } 2011 \text { SG }\end{array}$} & cet. XR & $0.0059 x^{2}-0.0124 x-0.0198$ & 0.9073 \\
\hline & cer. ADI & $0.0344 \mathrm{x}-0.0869$ & 0.7552 \\
\hline & kem UF & $-2.0187 \operatorname{Ln}(x)-0.4076$ & 0.9198 \\
\hline & kem LD & $0.0439 x^{2}-0.5914 x-0.1051$ & 0.6779 \\
\hline & aço i. XR & $3.4069 \ln (x)+0.6301$ & 0.9743 \\
\hline & acoi. DG & $1.3466 \ln (x)+0.3861$ & 0.9081 \\
\hline \multirow{6}{*}{$\begin{array}{l}\text { Carbeto de Silicio } \\
\text { SIC } 240\end{array}$} & er. XR & $0.2645 \mathrm{x}^{2}-2.297 \mathrm{x}-1.5648$ & 0.9828 \\
\hline & cer. ADI & $-0.0175 x^{2}+1.1153 x-3.5080$ & 0.9388 \\
\hline & kem UF & $39.383 \times-9.3265$ & 0.9719 \\
\hline & kem LD & $21.323 x+2.4498$ & 0.9847 \\
\hline & aco i. XR & $35.052 x+7.2973$ & 0.9835 \\
\hline & aço i. DG & $-0.0456 x^{2}+2.0642 x-8.0488$ & 0.8468 \\
\hline \multirow{6}{*}{$\begin{array}{l}\text { Carbeto de Silicio } \\
\text { SIC } 500\end{array}$} & cer. XR & $-0.0066 x^{2}+0.562 x-1.875$ & 0.9448 \\
\hline & er. ADI & $-0.0021 x^{2}+0.1637 x-0.3205$ & 0.9332 \\
\hline & $\operatorname{kem} U F$ & $-0.0034 x^{2}+2.0567 x-6.6337$ & 0.9742 \\
\hline & $\mathrm{kem}$ LD & $-0.0127 x^{2}+1.755 x-0.7381$ & 0.9794 \\
\hline & aço i. XR & $-0.0956 x^{2}+7.8058 x-11.456$ & 0.9798 \\
\hline & aco i. DG & $-0.0101 x^{2}+0.848 x+3.8312$ & 0.9492 \\
\hline \multirow{6}{*}{$\begin{array}{l}\text { Óxido de Alumínio Branco } \\
\text { (FFF) }\end{array}$} & er. XR & $-0.0085 x^{2}+0.9753 x-4.0946$ & 0.9747 \\
\hline & er. $\mathrm{ADI}$ & $-0.0031 x^{2}+0.2544 x-0.3143$ & 0.9756 \\
\hline & $\mathrm{kem}$ LF & $16.671 \times-0.944$ & 0.9960 \\
\hline & kem LD & $13.616 x+4.548$ & 0.9663 \\
\hline & aço i. XR & $30.623 x+5.755$ & 0.9612 \\
\hline & acoi. DG & $-0.0158 x^{2}+1.2121 x-6.7938$ & 0.9092 \\
\hline \multirow{6}{*}{$\begin{array}{l}\text { Bióxido de Silicio } \\
\text { Tixosil } 73\end{array}$} & cer. . IR & $0.0072 x^{2}+0.6158 x+2.4138$ & 0.9533 \\
\hline & cer. $A D I$ & $-0.0016 x^{2}+0.1407 x-0.4423$ & 0.9462 \\
\hline & $\mathrm{kem}$ LF & $5.3829 x+2.8940$ & 0.9922 \\
\hline & kern LD & $-0.0226 x^{2}+2.5694 x+5.6749$ & 0.9879 \\
\hline & aço i. XR & $20.3210 \operatorname{Ln}(x)-3.5316$ & 0.9529 \\
\hline & aço i. DG & $-0.0091 x^{2}+0.7779 x-2.5943$ & 0.9621 \\
\hline \multirow{6}{*}{$\begin{array}{l}\text { Areia de Fundição } \\
\text { para Shelmold }\end{array}$} & cer. XR & $-0.0098 x^{2}+0.9724 x+4.8181$ & 0.9410 \\
\hline & cer. ADI & $-0.0029 x^{2}+0.2747 x-3.7337$ & 0.7118 \\
\hline & kem UF & $3.181 \times-2.876$ & 0.9978 \\
\hline & kem LD & $1.5851 x+2.5624$ & 0.9839 \\
\hline & aço i. XR & $-0.0182 x^{2}+2.6427 x-12.752$ & 0.9683 \\
\hline & aço i. DG & $-0.0067 \mathrm{x}^{2}+0.8558 \mathrm{x}+3.2157$ & 0.9770 \\
\hline
\end{tabular}

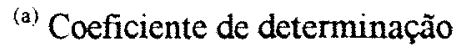


horas de teste. A ordem decrescente de durabilidade para este abrasivo, após trinta horas de teste foi : cer. ADI, aço i. DG, cer. Xr, kem LD, kem UF e aço i. XR. Cabe salientar que o bico de aço inox DG apresentou maior resistência ao desgaste que o bico de cerâmica $\mathrm{XR}$, chegando ao final do teste com 30,75 e $62,00 \%$, respectivamente, o que permite afirmar que o tipo de bico tem enorme influência sobre a sua resistência ao desgaste.

Para o abrasivo Carbeto de Silício - SIC 500 (Figura 17) o bico de aço inox XR mostra no gráfico, valores porcentuais de vazão até 10 horas de teste, tendo atingido $72,51 \%$. Para o bico de kematal UF o teste foi interrompido com trinta e cinco horas, quando atingiu $62,24 \%$ de aumento da vazão. Para esse abrasivo a ordem decrescente de durabilidade, após cinqüenta horas de teste foi : cer. ADI, cer. XR, aço i. DG, kem LD, kem UF e aço i. XR.

O desgaste sofrido pelos bicos quando sob ação do abrasivo Óxido de Alumínio Branco (FFF) (Figura 18) foi semelhante ao ocorrido no abrasivo Carbeto de Silício - SIC 240, com exceção ao comportamento dos bicos cer. XR e aço i. DG. Enquanto para o Carbeto de Silício - SIC 240, esses bicos tiveram diferenças discrepantes no final do teste, para o Oxido de Alumínio Branco (FFF), as diferenças de médias do aumento porcentual da vazão foram semelhantes para ambos os bicos. O bico de cerâmica ADI, praticamente, não apresentou desgaste, chegando ao final do teste com aumento porcentual na vazão de $5,0 \%$. A ordem de durabilidade, após cinqüenta horas de teste, foi igual a do abrasivo Carbeto de Silício - SIC 240. Nota-se que ambos, são produtos altamente abrasivos, não sendo indicados, nesta concentração, para testes com os bicos de kematal UF e LD e para o bico de aço inox XR.

A Figura 19 referente ao abrasivo Bióxido de Silicio - Tixosil 73, mostra uma nítida dispersão das curvas do gráfico. Observa-se que os bicos que mais se desgastaram foram os de kematal, enquanto que, até então, para todos os outros abrasivos anteriores $o$ bico de aço inox $X R$ era o que mais se desgastava. $O$ comportamento dos bicos cer. XR e aço i. DG utilizando este abrasivo, foi semelhante ao 
do anterior. Para esse abrasivo a ordem decrescente de durabilidade, após cinqüenta horas de teste foi : cer. ADI, cer. XR, aço i. DG, aço i. XR, kem LD e kem UF.

O gráfico que demonstra o comportamento do aumento porcentual da vazão, utilizando o abrasivo Areia de Fundição para Shellmold (Figura 20) indica que o bico aço i. XR apresentou maior desgaste nas primeiras horas sendo ultrapassado pelo bico de kematal UF com vinte e cinco horas, tendo este, a partir de então, aumentos acentuados da vazão. O comportamento dos bicos cer. XR e aço i. DG utilizando este abrasivo, foi semelhante ao dos dois últimos abrasivos, isto é, apresentaram resistência similar ao desgaste. A ordem decrescente de durabilidade no final do teste foi : cer. ADI, aço i. DG, cer. XR, , kem LD, aço i. XR, e kem UF.

De maneira geral para todos os abrasivos estudados, observou-se que a ordem de durabilidade dos bicos foi: cer. ADI, cer. XR, aço i. DG, kem LD, kem UF e aço i. XR.

$\mathrm{O}$ bico aço i. XR foi o que sofreu maior desgaste para maioria dos abrasivos estudados com exceção dos abrasivos Bióxido de Silicio - Tixosil 73 e Areia de Fundição para Shellmold. O bico que sofreu menor desgaste para maioria dos abrasivos estudados foi o cerâmica ADI, com exceção do abrasivo Coríndon - grão 800 .

Observando-se os gráficos verifica-se que todos os bicos de baixa deriva (cer. ADI, kem LD e aço i. DG) apresentam maior resistência ao desgaste em relação aos bicos de uso ampliado (cer. XR, kem UF e aço i. XR), confeccionados do mesmo material. Conforme Barnett \& Matthews (1992), Nordbo et al. (1995) e Thronhill \& Matthews (1996), os bicos de baixa deriva possuem um pré-orificio que produz uma queda da pressão e da velocidade da gota, o que pode explicar uma maior resistência ao desgaste em razão de diminuir a ação do abrasivo ao passar pelo orificio elíptico.

Verifica-se, ainda, que a ordem de resistência ao desgaste dos bicos estudados quanto ao tipo e material de confecção, variou de acordo com o abrasivo utilizado no teste. 


\subsubsection{Análise dos abrasivos por bico}

As Figuras 21 a 26 apresentam o comportamento dos abrasivos para um mesmo bico, com o objetivo de avaliar o abrasivo de melhor atuação para realização de testes de desgaste acelerado para o respectivo bico, variando este quanto o tipo e material de confecção.

Os bicos de cerâmica XR e ADI (Figuras 21 e 22) apresentaram alta resistência ao desgaste para os quatro primeiros abrasivos testados, que são Coríndon grão 800, Carbeto de Silíco - SIC 800, Caulim O.B. 2150 e Alumina Calcinada APC 2011 SG. Por isso procurou-se empregar materiais de maior abrasividade. O Carbeto de Silíco - SIC 240 foi o abrasivo que mais desgastou a cerâmica elevando a vazão para $62 \%$ e para $21,7 \%$ para os bicos XR e ADI, respectivamente.

Para o bico de cerâmica XR (Figura 21) os abrasivos Óxido de Alumínio Branco (FFF) e a Areia de Fundição conseguiram elevar a vazão a aproximadamente $30 \%$, com aumentos constantes desta, ao longo do tempo do teste. Já para o bico ADI (Figura 22), a Areia de Fundição provocou uma rápida elevação da vazão na primeira hora do teste, sendo que, após isto, a vazão teve comportamento irregular. Para o bico de cerâmica $\mathrm{ADI}$ fica dificil fazer uma avaliação nos testes de desgaste acelerado, quando utilizando os abrasivos Coríndon - grão 800, Carbeto de Silíco - SIC 800, Caulim O.B. 2150, Alumina Calcinada APC 2011 SG, Carbeto de Silíco - SIC 500, Tixosil e Óxido de Aluminio (FFF) pois, estes não conseguiram elevar a vazão em pelo menos $5 \%$, com cinqüenta horas de teste.

Através da Figura 23, observa-se que para o bico de kematal UF, os abrasivos se comportaram de forma bastante diferenciada, isto é, as curvas do gráfico estão dispersas umas das outras. Contudo, verifica-se que a maioria dos abrasivos atuam de tal forma que nas primeiras horas a vazão do bico tende a diminuir, para depois então começar a aumentar, sendo ainda que para o abrasivo Alumina Calcinada APC 2011 SG, a vazão deste bico apresentou decréscimos até o final do teste. 

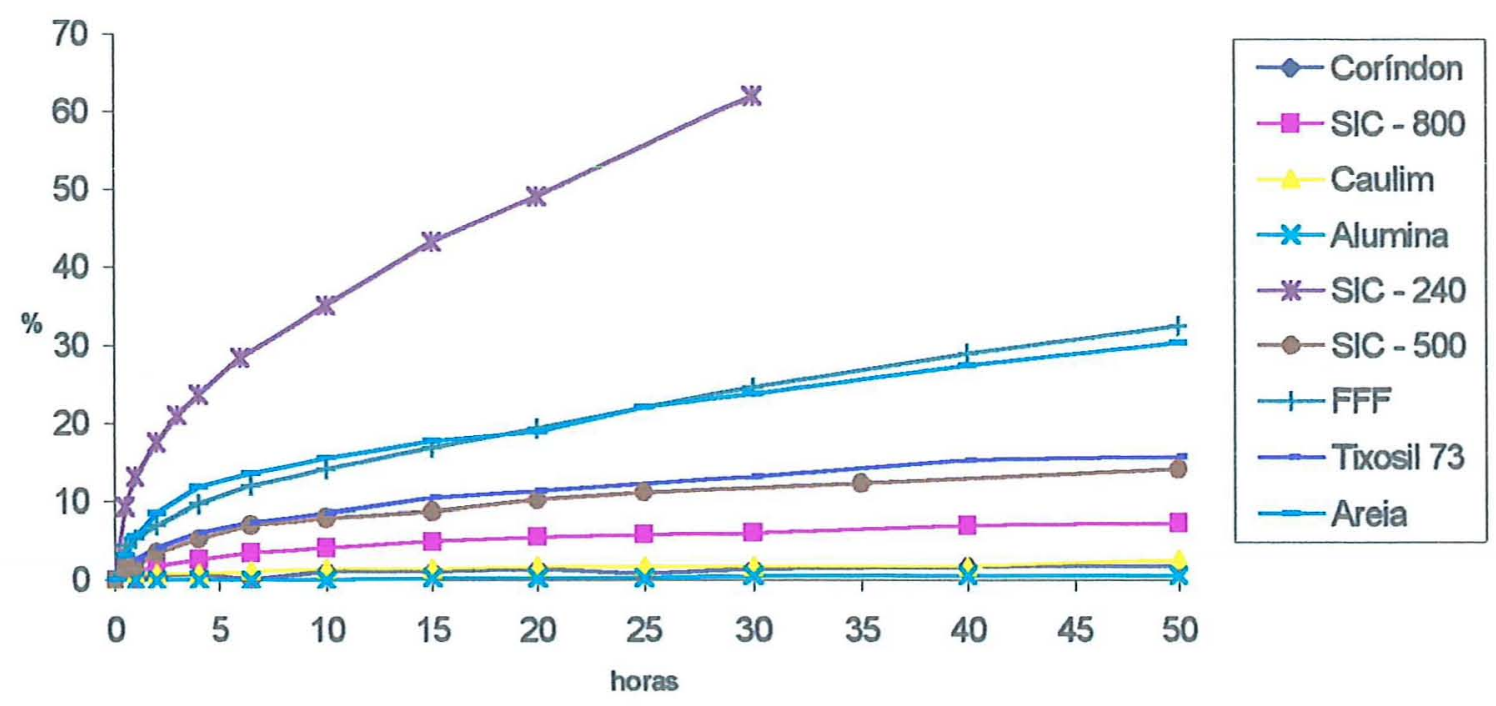

Figura 21. Gráfico do aumento porcentual da vazão em função do tempo para o bico de cerâmica XR

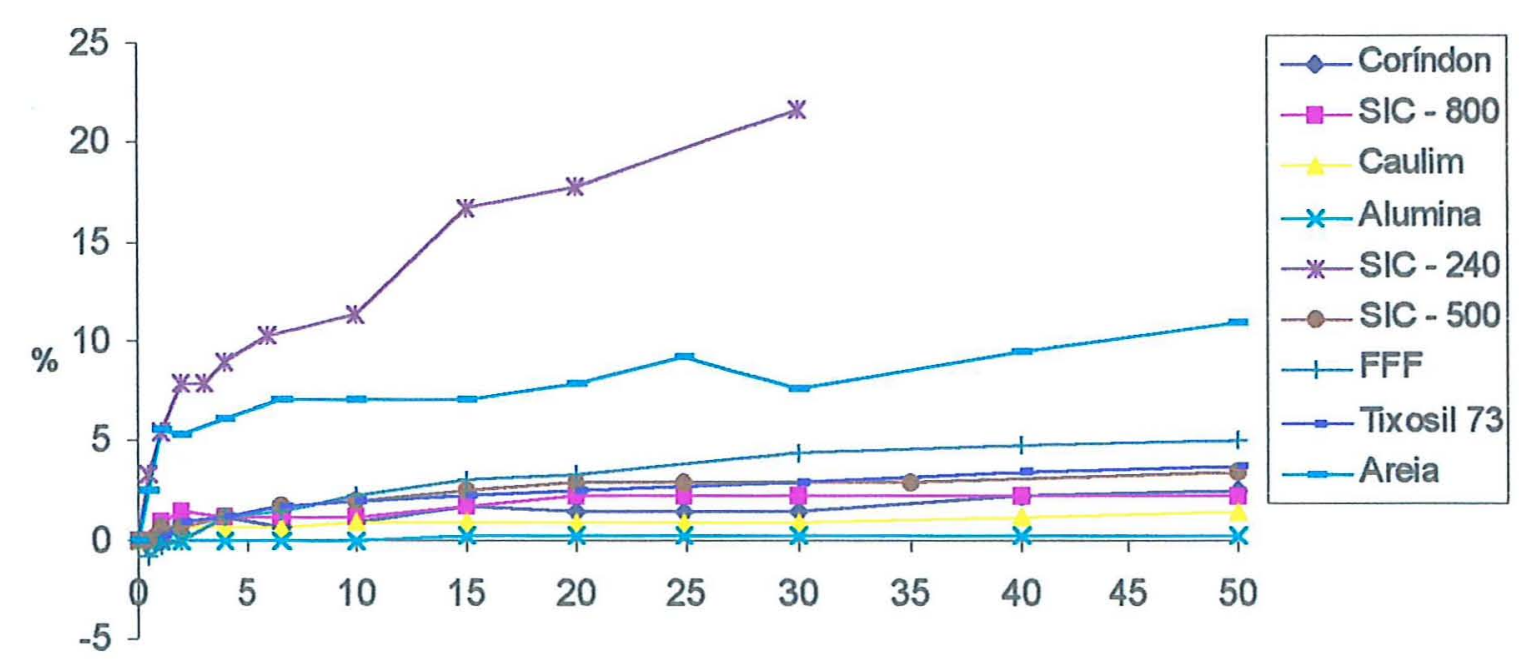

horas

Figura 22. Gráfico do aumento porcentual da vazão em função do tempo para o bico de cerâmica ADI 


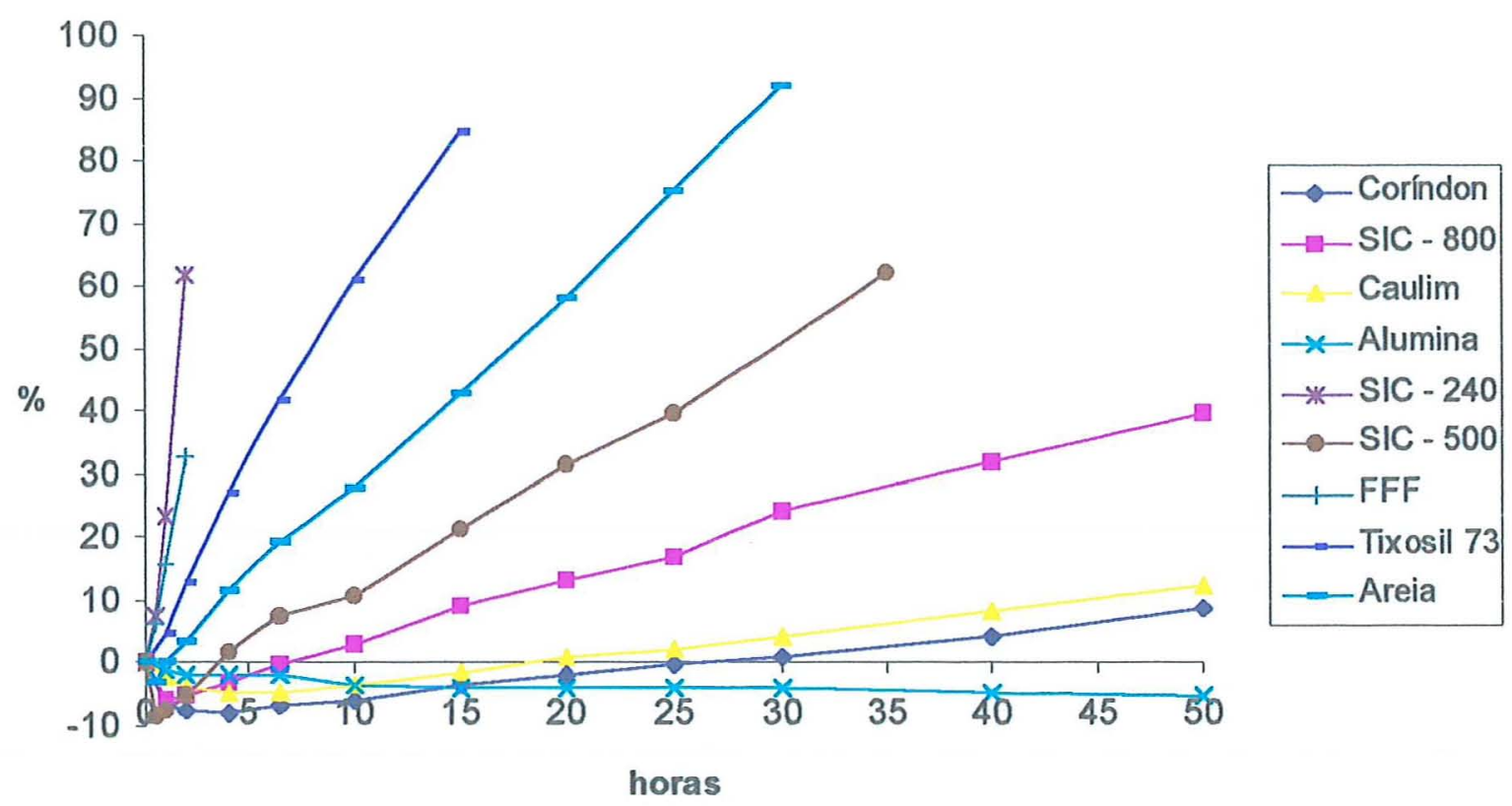

Figura 23. Gráfico do aumento porcentual da vazão em função do tempo para o bico de kematal UF

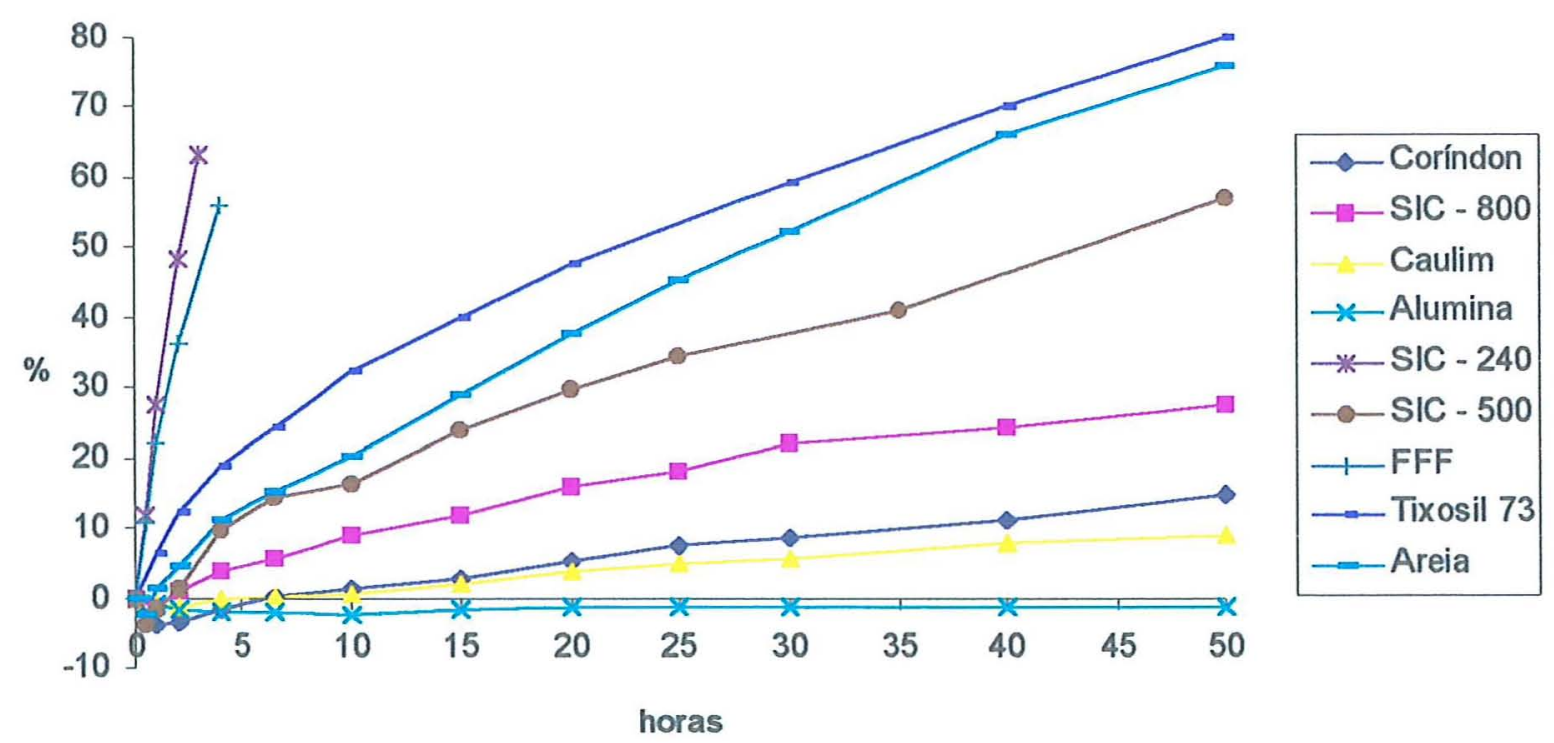

Figura 24. Gráfico do aumento porcentual da vazão em função do tempo para o bico de kematal LD 


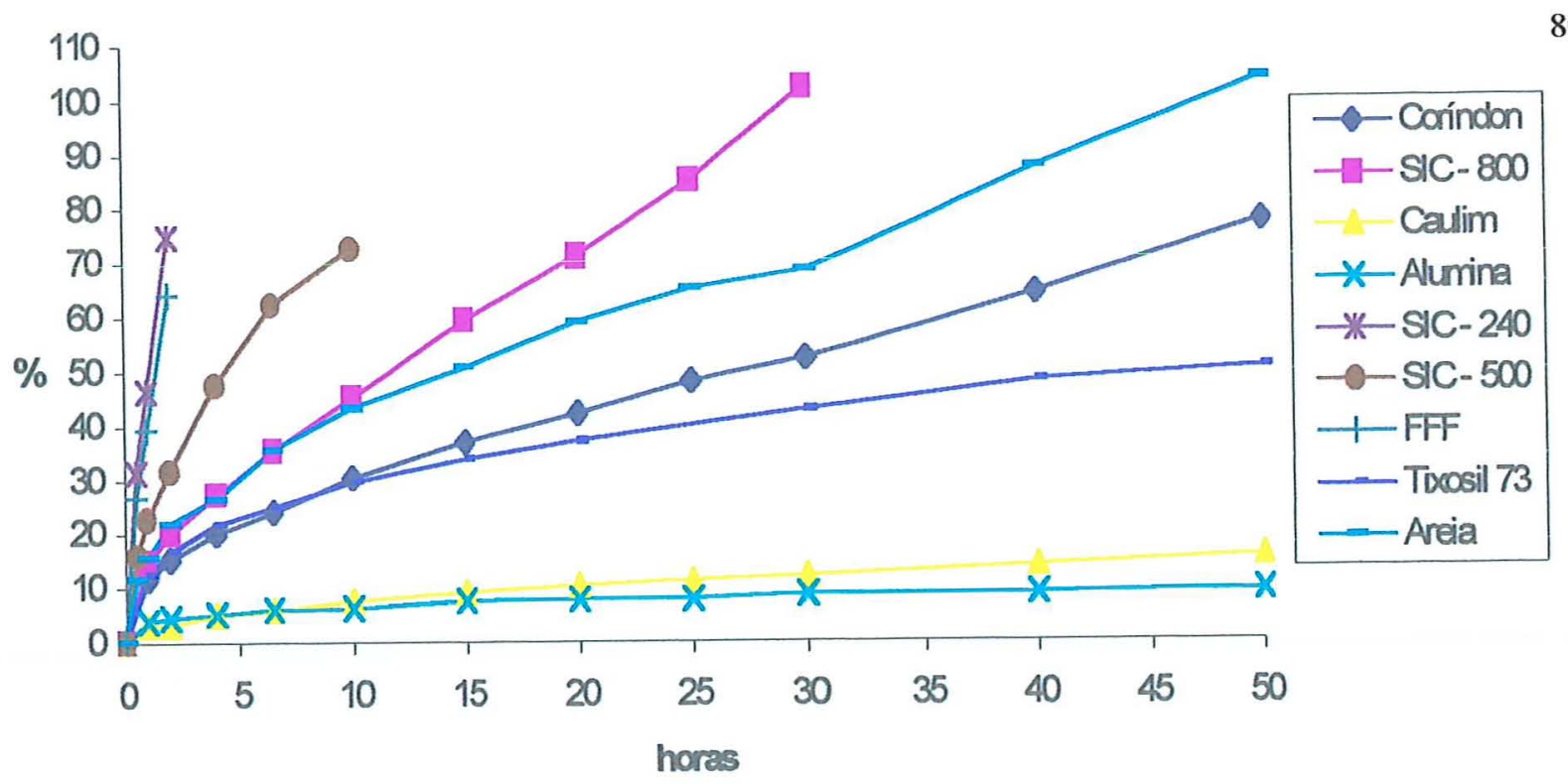

Figura 25. Gráfico do aumento porcentual da vazão em função do tempo para o bico de aço inox XR

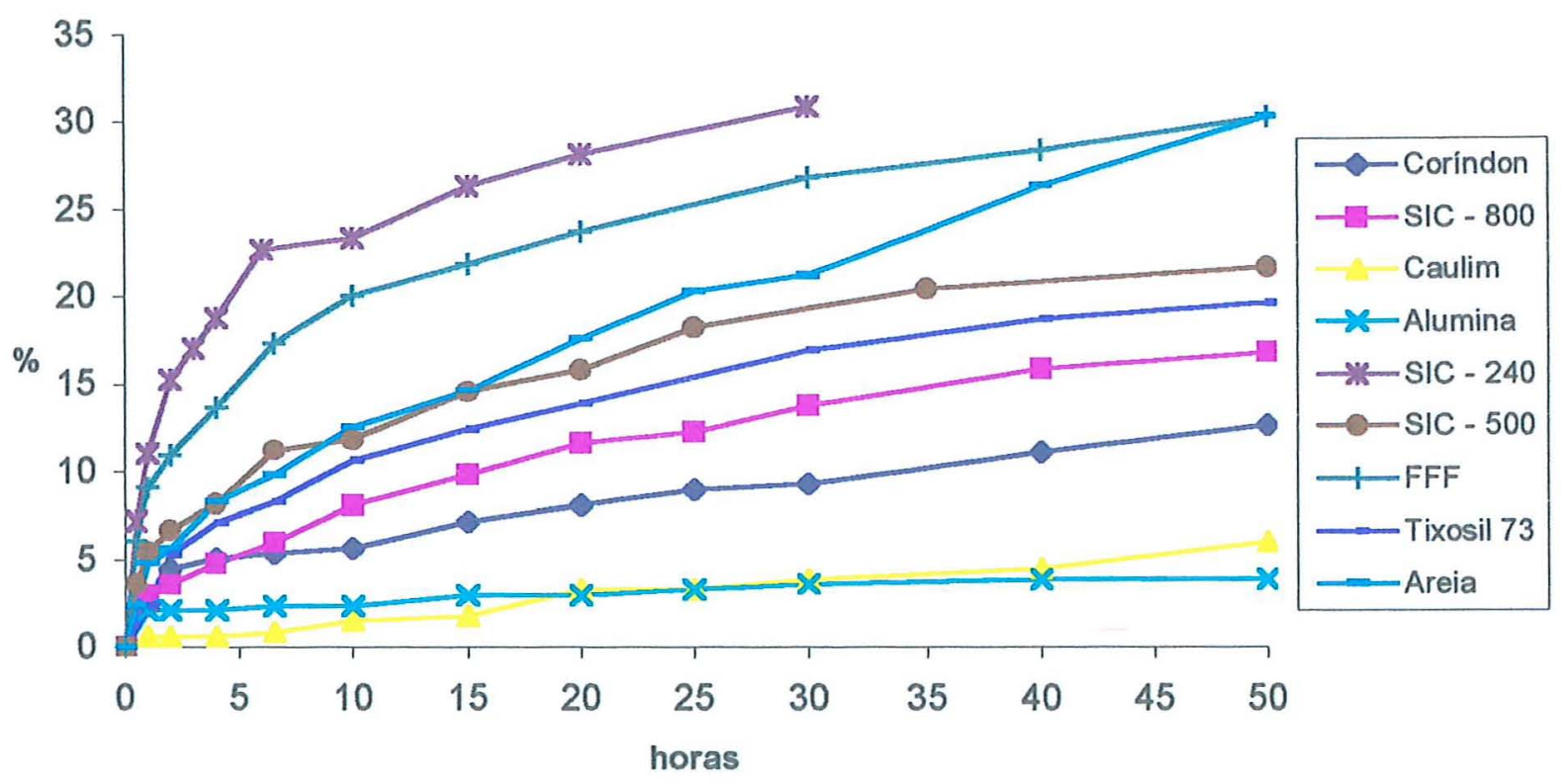

Figura 26. Gráfico do aumento porcentual da vazão em função do tempo para o bico de aço inox DG 
Verifica-se, ainda, que quanto menor a abrasividade do material, mais tempo a variação porcentual permanece com valores negativos e, para os abrasivos Carbeto de Silicio SIC 240 e o Tixosil 73, o bico não demonstrou valores de vazão negativos, devido a alta abrasividade desses produtos. Ainda, na Figura 23, atentando para as curvas dos abrasivos Carbeto de Silício - SIC 240, SIC 500 e SIC 800, nota-se, nitidamente, que o aumento da vazão foi influenciado pela granulometria, uma vez que se trata do mesmo produto, utilizado na mesma concentração.

Para o bico de kematal LD (Figura 24), o comportamento dos abrasivos foi semelhante ao ocorrido no bico anterior seguindo, praticamente, a mesma ordem de abrasividade. Para este bico a variação porcentual também assumiu valores negativos nas primeiras horas, sendo que, este efeito, ocorreu com menor intensidade neste caso. Analisando conjuntamente as Figuras 23 e 24, verifica-se que o bico de baixa deriva apresentou maior resistência ao desgaste, para todos os abrasivos testados. Salienta-se, ainda que, para ambos os casos, os abrasivos Carbeto de Silíco - SIC 240 e Óxido de Alumínio Branco (FFF), não seriam recomendados para testes com esses bicos pois, apresentam uma ação violenta sobre o desgaste do orificio, fazendo com que a vazão se eleve, proporcionando altos níveis de desgaste com poucas horas de teste. Esta afirmação leva em consideração os parâmetros indicados na norma NBR 13769 (1997), onde cita que testes acelerados devem ser conduzidos até cinqüenta horas ou até cinqüenta porcento de aumento da vazão, supondo que o ideal seja que isso aconteça simultaneamente.

Para o bico de aço inox XR (Figura 25), a ordem de abrasividade dos produtos foi bastante adversa em comparação a ordem obtida pelos bicos de kematal, permitindo afirmar que a abrasividade do produto atuou de forma diferente no kematal e no aço inox ou, ainda que, a ordem de resistência desses dois bicos é variável em função do abrasivo utilizado no teste. Semelhantemente aos bicos de kematal, os abrasivos Carbeto de Silício - SIC 240 e o Óxido de Alumínio Branco (FFF), não seriam indicados para testes com este bico, devido ao brusco aumento da vazão já nas primeiras horas. Os abrasivos Alumina Calcinada APC 2011 SG e o Caulim O.B. 2150 foram os produtos 
que menos desgastaram o bico de aço inox XR, chegando ao final do teste com aumentos porcentuais da vazão de 9,27 e $15,45 \%$, respectivamente.

A atuação dos produtos abrasivos sobre o bico de aço inox DG, como se observa na Figura 26, também apresentou curvas bastante dispersas porém, na sua maioria com tendência a estabilização do aumento da vazão em função do tempo o que difere das curvas para os bicos de kematal. A ordem decrescente de abrasividade dos produtos para este bico foi: Carbeto de Silício - SIC 240, Óxido de Alumínio Branco (FFF), Areia de Fundição, Carbeto de Silício - SIC 500, Tixosil 73, Carbeto de Silicio SIC 800, Coríndon, Caulim e Alumina Calcinada.

\subsubsection{Resistência relativa dos bicos}

Na Tabela 13 estão apresentados os valores de comparação relativa entre os aumentos porcentuais da vazão dos bicos, para cada abrasivo, demonstrando a seqüência dos bicos quanto a resistência ao desgaste.

Os resultados foram obtidos e expressos através de um valor, definido pela relação entre o aumento porcentual do bico de aço inox XR com os demais, considerando este como material de referência, tendo recebido o valor 1. Para cada abrasivo os valores do aumento porcentual relativo foi calculado com base no tempo máximo de teste de tal forma que estivessem presentes todas as médias dos seis bicos.

O abrasivo Coríndon teve um comportamento diferenciado dos demais, isto é, a seqüência de resistência ao desgaste não seguiu a mesma ordem da maioria. $O$ bico de kematal UF apresentou maior resistência ao desgaste que os bicos de kematal LD e de aço inox DG. Os bicos de cerâmica tiveram ordem de resistência inversa, quando comparada com os demais abrasivos. 
Tabela 13. Comparação relativa entre os aumentos porcentuais da vazão dos bicos para cada abrasivo

\begin{tabular}{ccrrrrrr}
\hline Abrasivos & Horas $^{(b)}$ & aço i. XR & kem UF & kem LD & aço i. DG & cer. XR & cer. ADI \\
\hline Coríndon & 50 & 1 & 8,66 & 5,25 & 6,17 & 44,00 & 30,37 \\
SIC - 800 & 40 & 1 & 4,23 & 5,56 & 8,52 & 19,16 & 60,04 \\
Caulim & 50 & 1 & 1,25 & 1,71 & 2,59 & 5,87 & 10,94 \\
Alumina & 50 & 1 & $-(a)$ & - & 2,37 & 15,83 & 33,58 \\
SIC - 240 & 3 & 1 & 0,96 & 1,76 & 6,56 & 5,30 & 14,23 \\
SIC - 500 & 20 & 1 & 4,19 & 4,46 & 8,40 & 12,94 & 46,60 \\
FFF & 2 & 1 & 1,96 & 1,77 & 5,87 & 9,13 & - \\
Tixosil 73 & 20 & 1 & 0,35 & 0,78 & 2,67 & 3,25 & 14,47 \\
Areia & 40 & 1 & 0,68 & 1,32 & 3,33 & 3,18 & 9,15 \\
\hline Média & & 1 & 2,78 & 2,82 & 5,16 & 13,18 & 27,42 \\
\hline
\end{tabular}

* Valores maiores indicam maior resistência ao desgaste

(a) Valor não obtido devido apresentar média negativa

${ }^{\text {(b) }}$ Tempo máximo de teste para cada abrasivo, tendo presente os seis bicos

Os bicos apresentaram a mesma ordem de resistência ao desgaste para cinco dos nove abrasivos testados, sendo eles: Carbeto de Silício - SIC 800, Caulim, Alumina, Carbeto de Silício - SIC 500 e Tixosil 73. Esta sequiência seguiu a mesma ordem da média.

O bico de aço inox DG apresentou maior resistência ao desgaste que o bico de cerâmica XR, para os abrasivos Carbeto de Silício - SIC 240 e Areia de Fundição, observando-se que estes abrasivos possuem os maiores valores de granulometria.

O bico de kematal UF quando sob a ação dos abrasivos Carbeto de Silicio - SIC 240, Tixosil 73 e Areia de Fundição, apresentou menor resistência ao desgaste que o bico de referência (aço inox XR). O abrasivo Tixosil 73 teve uma maior atuação nos bicos de kematal UF e LD, sendo estes os bicos de menor resistência para este abrasivo. 
Tabela 14. Comparação relativa entre os aumentos porcentuais da vazão entre bicos de baixa deriva e uso ampliado de cada material, para cada abrasivo

\begin{tabular}{cccccccc}
\hline Abrasivos & Horas $^{(b)}$ & \multicolumn{2}{c}{ Aço Inox } & \multicolumn{2}{c}{ Kematal } & \multicolumn{2}{c}{ Cerâmica } \\
\cline { 2 - 7 } & & XR & DG & UF & LD & XR & ADI \\
\hline Corindon & 50 & 1 & 6,17 & 1 & 0,61 & 1 & 0,69 \\
SIC - 800 & 40 & 1 & 8.52 & 1 & 1,31 & 1 & 3,13 \\
Caulim & 50 & 1 & 2.59 & 1 & 1,37 & 1 & 1,86 \\
Alumina & 50 & 1 & 2.37 & 1 & $-\underbrace{(a)}$ & 1 & 2.12 \\
SIC - 240 & 3 & 1 & 6.56 & 1 & 1.83 & 1 & 2.68 \\
SIC - 500 & 20 & 1 & 8.40 & 1 & 1,06 & 1 & 3.06 \\
FFF & 2 & 1 & 5.87 & 1 & 0.90 & 1 & - \\
Tixosil 73 & 20 & 1 & 2,67 & 1 & 2,23 & 1 & 4,45 \\
Areia & 40 & 1 & 3,33 & 1 & 1.94 & 1 & 2.88 \\
Média & & 1 & 5,16 & 1 & 1,41 & 1 & 2,68
\end{tabular}

* Valores maiores indicam maior resistência ao desgaste

(a) Valor não obtido devido apresentar média negativa

(b) Tempo máximo de teste para cada abrasivo, tendo presente os seis bicos

Através da Tabela 13, pode-se observar que a ordem e o valor relativo da resistência ao desgaste dos bicos quanto ao tipo e material de confeç̧ão, variou de acordo com o abrasivo utilizado no teste, o que permite afirmar que não se pode generalizar uma ordem de resistência para os materiais de confecção dos bicos.

Observando-se a Tabela 14 verifica-se que os bicos de baixa deriva apresentaram maior resistência ao desgaste em relação aos de uso ampliado, confeccionados do mesmo material. As médias de resistência relativa ao desgaste dos dois tipos bicos (baixa deriva e uso ampliado) para os materiais aço inox, kematal e cerâmica são 5,16,1,41 e 2,68, respectivamente. 


\subsection{Avaliação dos ensaios no teste final}

Para os ensaios denominados de teste final foi escolhido, dentre os nove materiais do pré-teste, apenas o abrasivo Óxido de Alumínio Branco (FFF) em razão deste estar especificado na segunda edição da norma ISO 5682-1 (1997) como o produto a ser usado em teste de desgaste acelerado de bicos pulverizadores. Com base nos resultados do pré-teste para este abrasivo, no teste final prosseguiu-se com mais estudos das características funcionais dos bicos em função dos níveis de desgaste. Foram avaliados os tempos para alcançar determinados níveis de desgaste e as medidas dos diâmetros da elipse, com aplicação do teste de Tukey, ao nível de 5\%, e determinação de equações de regressão. Além disso, foram realizados estudos do perfil de distribuição, através das avaliações dos gráficos, da variação do $\mathrm{CV}$ da uniformidade de distribuição e do comportamento do $\mathrm{CV}$ nas três repetições de cada canaleta para os diferentes niveis de desgaste. Avaliou-se, também, a simetria volumétrica da distribuição e o ângulo do jato. Todas as avaliações citadas acima foram feitas para cada um dos seis bicos.

A norma ASAE S471 Dec 95 (1996) indica o Caulim como material abrasivo a ser usado em testes desgaste, entretanto, após os ensaios realizados no préteste com este material verificou-se baixos níveis de desgaste para o tempo de realização do teste, principalmente para os bicos de cerâmica. Assim sendo, não foi possível a realização das avaliações do teste final com este abrasivo.

\subsubsection{Análise dos tempos para os níveis de desgaste}

A Tabela 15 mostra as médias do tempo para alcançar determinados níveis de desgaste dos bicos sob a ação do abrasivo Óxido de Alumínio Branco (FFF), com aplicação de Tukey a 5\%. Observa-se que tempos maiores indicam maior resistência ao desgaste. Os dados originais dos tempos para alcançar os níveis de desgaste encontram-se no Apêndice 10. 
Os resultados apresentados na Tabela 15 mostram que o bico de cerâmica ADI foi o mais resistente atingindo $10 \%$ de aumento da vazão com 60,27 horas, encerrando o teste para este. O bico cerâmica XR apresenta-se como o segundo mais resistente até o nivel de $20 \%$, sendo que a $30 \%$, foi ultrapassado pelo bico de aço inox DG. Ambos chegaram ao limite do tempo do teste com valores de 49,33 e 60,04 horas para os bicos cerâmica XR e aço inox DG, respectivamente. Os bicos de kematal UF e LD e o de aço inox XR tiveram valores de tempo muito inferiores aos primeiros, atingindo $50 \%$ de nível de desgaste com 3,58 , 3,94 e 1,58 horas, respectivamente. Estes bicos, de maneira geral, não apresentaram diferença significativa entre si até $30 \%$ de nivel de desgaste. Para os níveis de 40 e $50 \%$ não foi aplicado o teste de Tukey em razão do baixo grau de liberdade de tratamentos para esse teste, não garantindo a confiabilidade das comparações.

Tabela 15. Médias do tempo para alcançar determinados níveis de desgaste dos bicos sob a ação do abrasivo Óxido de Alumínio Branco (FFF), com aplicação de Tukey a $5 \%$.

\begin{tabular}{lcrrrrr}
\hline \multicolumn{7}{c}{ Niveis de Desgaste $^{\circ}$} \\
\hline Bicos & 5 & 10 & 20 & 30 & 40 & 50 \\
\hline cer. XR & $0,950^{\mathrm{B}}$ & $5,041^{\mathrm{B}}$ & $24,782^{\mathrm{A}}$ & $49,336^{\mathrm{B}}$ & - & - \\
cer. ADI & $9,262^{\mathrm{A}}$ & $60,273^{\mathrm{A}}$ & $-^{\text {(a) }}$ & - & - & - \\
kem UF & $0,709^{\mathrm{C}}$ & $0,907^{\mathrm{C}}$ & $1,759^{\mathrm{C}}$ & $2,444^{\mathrm{C}}$ & 3,095 & 3,580 \\
kem LD & $0,332^{\mathrm{D}}$ & $0,500^{\mathrm{C}}$ & $1,102^{\mathrm{D}}$ & $1,793^{\mathrm{C}}$ & 2,090 & 3,945 \\
aço i. XR & $0,023^{\mathrm{E}}$ & $0,073^{\mathrm{C}}$ & $0,269^{\mathrm{E}}$ & $0,642^{\mathrm{C}}$ & 1,098 & 1,582 \\
aço i. DG & $0,349^{\mathrm{D}}$ & $1,100^{\mathrm{C}}$ & $11,000^{\mathrm{B}}$ & $60,037^{\mathrm{A}}$ & - & - \\
\hline
\end{tabular}

- Médias seguidas de letras diferentes na coluna, apresentam diferença significativa a $5 \%$

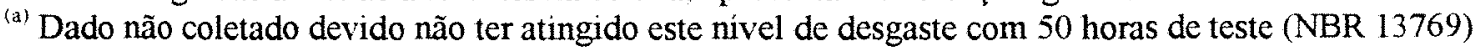

$\mathrm{Na}$ Tabela 16 estão apresentadas as equações de regressão que relacionam o nível de desgaste, em porcentagem do aumento da vazão (x), ao tempo, em horas, para atingi-lo (y). Para todos os bicos a equação linear foi suficiente para explicar grande parte do comportamento dessas variáveis, o que é observado pelos valores de $\mathrm{r}^{2}$. 
Os coeficientes angulares foram significativamente maiores que zero $(b \neq 0)$, o que indica um aumento crescente dos valores de tempo em função dos niveis de desgaste. Os bicos de cerâmica XR e ADI e o bico de aço inox DG apresentaram os maiores coeficientes angulares, indicando que necessitam de um maior tempo para alcançar um determinado nível de desgaste, sendo portanto, os mais resistentes. Os demais bicos, apesar de terem mostrado coeficientes angulares baixos, foram também significativos.

Tabela 16. Equações de regressão linear para cada um dos seis bicos testados sob o abrasivo Óxido de Aluminio Branco (FFF), relacionando o nivel de desgaste $(\mathrm{x})$ e o tempo $(\mathrm{y})$

\begin{tabular}{cccc}
\hline Bicos & Equações & $\mathrm{r}^{2(\mathrm{a})}$ & $\mathrm{b} \neq 0$ \\
\hline cer. XR & $1,705982259 \mathrm{x}-6,15588002$ & 94,24 & $* *$ \\
cer. ADI & $6,027272667 \mathrm{x}-6,95795444$ & 86,21 & $* *$ \\
kem UF & $0,070370151 \times+0,22691235$ & 98,79 & $* *$ \\
kem LD & $0,077246528 \times-0,20016980$ & 97,56 & $* *$ \\
aço inox XR & $0,031948026 \mathrm{x}-0,18061197$ & 94,65 & $* *$ \\
aço inox DG & $1,881950610 \mathrm{x}-9,96816386$ & 76,76 & $* *$ \\
\hline
\end{tabular}

** indica significância ao nivel de $1 \%$ de probabilidade

(a) Coeficiente de determinação

A Figura 27 mostra os valores do aumento porcentual da vazão com o abrasivo Óxido de Alumínio Branco (FFF), no pré-teste, comparando com os resultados obtidos no teste final. O comportamento das curvas de cada bico são semelhantes em ambos os testes, o que indica uma excelente repetitividade do ensaio, garantindo, assim, grande confiabilidade nos resultados e conclusões obtidas sobre os bicos avaliados com este abrasivo. Isto garante também que o equipamento utilizado para o teste de desgaste apresentou-se adequado para este estudo. 

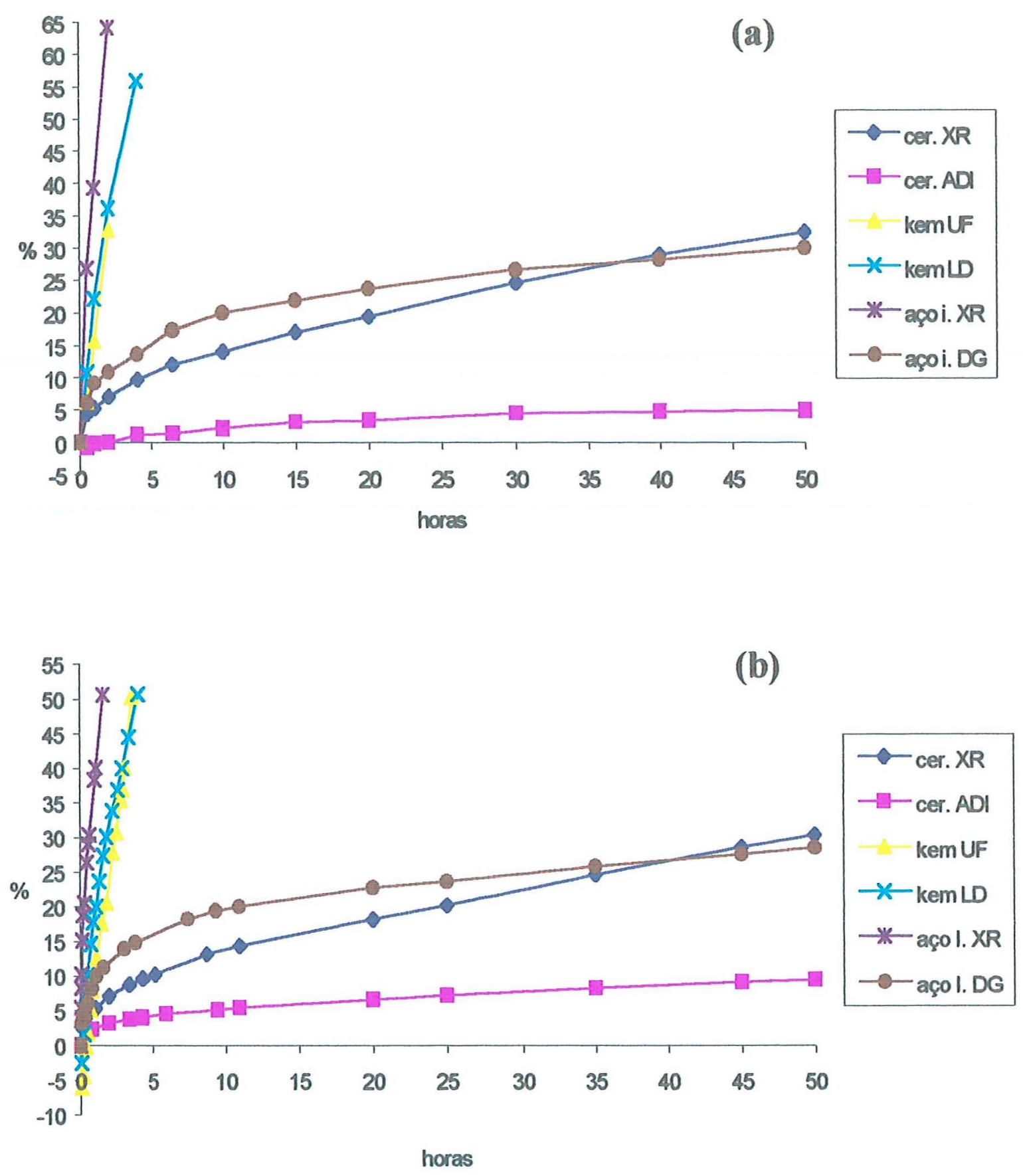

Figura 27. Gráficos comparativos do aumento percentual da vazão sob ação do abrasivo Óxido de Alumínio Branco (FFF) entre os ensaios Pré-Teste (a) e Teste Final (b). 
Nota-se ainda na Figura 27, que o cruzamento das curvas referente aos bicos de cerâmica XR e aço inox DG ocorreram com aproximadamente 40 horas de teste, verificando-se que, o bico de aço inox DG, apesar de apresentar maiores desgastes nas primeiras horas, tende a estabilizar-se, chegando ao final do teste com valores de resistência maiores que o de cerâmica XR.

Através do comportamento das curvas referentes aos bicos de kematal UF e LD e do bico aço inox XR, verifica-se que este abrasivo, nesta concentração, provoca um rápido desgaste desses bicos, o que não está próximo dos parâmetros da norma NBR 13769 onde estabelece que o teste deve ser conduzido até 50 horas ou até $50 \%$ de aumento da vazão.

\subsubsection{Análise dos diâmetros da elipse}

Para o bico novo e nos diversos niveis de desgaste estabelecidos pela norma NBR 13769 foram medidos os diâmetros maior (X) e menor (Y) do orificio do bico que tem formato de elipse. Na Tabela 17 encontram-se as médias, em mm, do diâmetro maior $(\mathrm{X})$, com aplicação do teste de Tukey a 5\% para cada um dos niveis de desgaste. Observa-se que, quando novos, os bicos, apesar de possuirem a mesma vazão nominal, apresentam diferenças significativas entre as médias para o valor $\mathrm{X}$

Tabela 17. Médias do aumento do diâmetro maior da elipse $(X)(\mathrm{mm})$ em função dos niveis de desgaste, para cada bico, com aplicação do teste de Tukey a $5 \%$.

\begin{tabular}{lccccccc}
\hline & \multicolumn{7}{c}{ Níveis de Desgaste } \\
\hline Bicos & 0 & 5 & 10 & 20 & 30 & 40 & 50 \\
\hline cer. XR & $1,810^{\mathrm{E}}$ & $1,808^{\mathrm{F}}$ & $1,801^{\mathrm{E}}$ & $1,804^{\mathrm{D}}$ & $1,806^{\mathrm{D}}$ & - & - \\
cer. ADI & $2,381^{\mathrm{A}}$ & $2,399^{\mathrm{A}}$ & $2,410^{\mathrm{A}}$ & $-^{\text {(a) }}$ & - & - & - \\
kem UF & $2,010^{\mathrm{C}}$ & $1,997^{\mathrm{C}}$ & $1,987^{\mathrm{C}}$ & $2,000^{\mathrm{B}}$ & $2,005^{\mathrm{B}}$ & 1,994 & 1,986 \\
kem LD & $1,945^{\mathrm{D}}$ & $1,947^{\mathrm{D}}$ & $1,961^{\mathrm{C}}$ & $1,994^{\mathrm{B}}$ & $1,999^{\mathrm{B}}$ & 2,015 & 2,033 \\
aço i. XR & $1,916^{\mathrm{D}}$ & $1,917^{\mathrm{E}}$ & $1,913^{\mathrm{D}}$ & $1,928^{\mathrm{C}}$ & $1,959^{\mathrm{C}}$ & 1,947 & 1,952 \\
aço i. DG & $2,234^{\mathrm{B}}$ & $2,266^{\mathrm{B}}$ & $2,263^{\mathrm{B}}$ & $2,296^{\mathrm{A}}$ & $2,369^{\mathrm{A}}$ & - & - \\
\hline
\end{tabular}

\footnotetext{
- Médias seguidas de letras diferentes na coluna. apresentam diferença significativa a $5 \%$

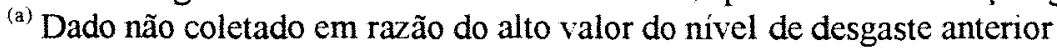


$\mathrm{Na}$ Tabela 18 encontram-se as médias, em $\mathrm{mm}$, referentes ao diâmetro menor da elipse (Y), onde observa-se que, os valores para os bicos de kematal UF e LD, quando novos, apresentam a maior discrepância em relação aos demais, tendo o bico de kematal UF o menor valor $(0,395)$ e o LD o maior valor $(0,619)$. Esta diferença pode ser visualmente notada através da Figura 29(c) e 30(a).

Tabela 18. Médias do aumento do diâmetro menor da elipse (Y) (mm) em função dos níveis de desgaste, para cada bico, com aplicação do teste de Tukey a 5\%.

\begin{tabular}{lccccccc}
\hline & \multicolumn{7}{c}{ Níveis de Desgaste } \\
\hline Bicos & 0 & 5 & 10 & 20 & 30 & 40 & 50 \\
\hline cer. XR & $0,549^{\mathrm{B}}$ & $0,551^{\mathrm{C}}$ & $0,554^{\mathrm{CD}}$ & $0,577^{\mathrm{B}}$ & $0,605^{\mathrm{B}}$ & - & - \\
cer. ADI & $0,560^{\mathrm{B}}$ & $0,706^{\mathrm{A}}$ & $0,787^{\mathrm{A}}$ & $-\overline{-a}^{(\mathrm{a})}$ & - & - & - \\
kem UF & $0,395^{\mathrm{D}}$ & $0,371^{\mathrm{E}}$ & $0,384^{\mathrm{E}}$ & $0,412^{\mathrm{D}}$ & $0,468^{\mathrm{C}}$ & 0,553 & 0,630 \\
kem LD & $0,619^{\mathrm{A}}$ & $0,569^{\mathrm{B}}$ & $0,621^{\mathrm{B}}$ & $0,651^{\mathrm{A}}$ & $0,710^{\mathrm{A}}$ & 0,822 & 0,919 \\
aço i. XR & $0,492^{\mathrm{C}}$ & $0,505^{\mathrm{D}}$ & $0,509^{\mathrm{D}}$ & $0,521^{\mathrm{C}}$ & $0,537^{\mathrm{BC}}$ & 0,557 & 0,582 \\
aço i. DG & $0,562^{\mathrm{B}}$ & $0,577^{\mathrm{B}}$ & $0,589^{\mathrm{BC}}$ & $0,638^{\mathrm{A}}$ & $0,801^{\mathrm{A}}$ & - & - \\
\hline
\end{tabular}

* Médias seguidas de letras diferentes na coluna, apresentam diferença significativa a $5 \%$

(a) Dado não coletado em razão do alto valor do nivel de desgaste anterior

Verifica-se que os bicos de baixa deriva, quando novos, possuem maiores valores dos diâmetros $\mathrm{X}$ e Y, com exceção da medida X para o bico de kematal LD. Esta característica pode ser explicada em razão de possuírem um pré-orificio circular, o qual produz uma queda da pressão e da velocidade da gota (Matthews \& Thronhill, 1996).

Pelo gráfico apresentado na Figura 28, verificou-se que o desgaste do orificio do bico foi maior no sentido do diâmetro menor da elipse, isto é, com o desgaste, a elipse teve tendência de tomar um formato arredondado, concordando com os resultados de Zhu et al. (1995), Ozkan et al. (1992 c ) e Barrufet et al. (1989). Este resultado pode ser visualizado através das Figuras 29 e 30. 


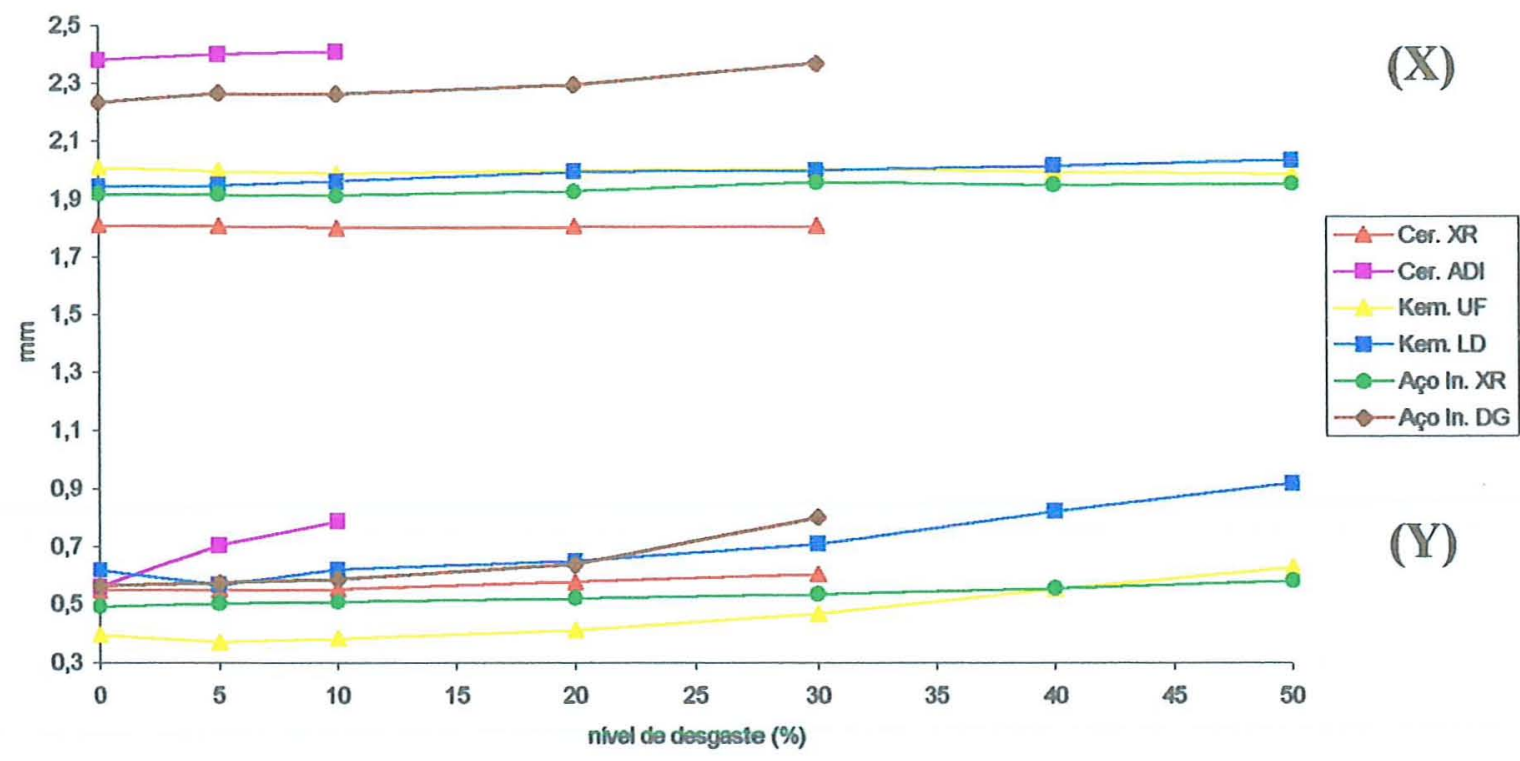

Figura 28. Gráfico do aumento dos diâmetros maior (X) e menor (Y) da elipse (mm) em função dos níveis de desgaste (\%).

As equações de regressão estimadas para representar o comportamento de do aumento dos diâmetros maior $(\mathrm{X})$ e menor (Y) da elipse, em função do nível de desgaste, para cada um dos seis bicos, estão apresentadas na Tabela 19. As equações que melhor explicaram a variação desses aumentos, foi a linear, sendo observados, de modo geral, altos valores de $r^{2}$. Para os bicos de cerâmica XR e de kematal UF, o coeficiente angular da reta não foi significativo para o diâmetro maior, o que indica que não houve aumento desta variável. Pode-se notar que os coeficientes angulares para a variável Y são ligeiramente maiores do que os coeficientes da variável $\mathrm{X}$. Isso concorda com os resultados discutidos no parágrafo anterior. Os aumentos lineares médios por unidade de nível de desgaste para os diâmetros maior e menor, variaram de 0,001 a 0,007, com exceção do bico de cerâmica $A D I$ que teve o aumento de $Y$ com valor de 0,022 , o que é explicado por problemas na medição, pois o pré-orificio impedia a focalização dos limites das paredes do orifício. 
Tabela 19. Equações de regressão linear, relacionando o nível de desgaste (\%) (y) e o diâmetro maior da elipse (variável $\mathrm{X}$, em $\mathrm{mm}$ ) e o diâmetro menor da elipse (variável $\mathrm{Y}$, em $\mathrm{mm}$ ), para cada um dos seis bicos testados.

\begin{tabular}{ccccccc}
\hline & \multicolumn{3}{c}{$\mathrm{X}$} & \multicolumn{4}{c}{$\mathrm{Y}$} \\
\cline { 2 - 7 } Bicos & Equações & $\mathrm{r}^{2(\mathrm{a})}$ & $\mathrm{b} \neq 0$ & Equações & $\mathrm{r}^{2(\mathrm{a})}$ & $\mathrm{b} \neq 0$ \\
\hline Cer. XR & $-0,0001132 \mathrm{x}+1,807$ & 14,33 & n.s. & $0,0019356 \mathrm{x}+0,542$ & 93,74 & $* *$ \\
Cer. ADI & $0,0029666 \mathrm{x}+2,382$ & 98,50 & $* *$ & $0,0226666 \mathrm{x}+0,570$ & 97,30 & $* *$ \\
Kem UF & $-0,0002196 \mathrm{x}+2,001$ & 22,03 & n.s. & $0,0049882 \mathrm{x}+0,348$ & 90,32 & $* *$ \\
Kem LD & $0,0018128 \mathrm{x}+1,945$ & 96,90 & $* *$ & $0,0064302 \mathrm{x}+0,559$ & 90,88 & $* *$ \\
Aço inox XR & $0,0009193 \mathrm{x}+1,912$ & 78,33 & $* *$ & $0,0016887 \mathrm{x}+0,491$ & 98,16 & $* *$ \\
Aço inox DG & $0,0041160 \mathrm{x}+2,232$ & 92,38 & $* *$ & $0,0075982 \mathrm{x}+0,534$ & 86,73 & $* *$ \\
\hline
\end{tabular}

** indica significância ao nível de $1 \%$ de probabilidade

n.s. indica não significância

(a) Coeficiente de determinação

As Figuras 29 e 30 mostram as fotografias do orificio para cada um dos tipos de bicos estudados, quando novos e após o teste. O bico fotografado foi tomado aleatoriamente entre as três repetições. Nota-se que, na maioria dos bicos, o diâmetro menor da elipse sofreu aumentos evidentes em relação ao maior. Os bicos de kematal UF e LD e de aço inox XR, com 50\% de nivel de desgaste, foram os que tiveram maiores aumentos no diâmetro menor, em relação aos demais bicos. Nota-se, ainda, para os bicos de kematal, a presença de uma rebarba do plástico nas paredes que sofreram maior desgaste. Para o bico de kematal LD observa-se, também, uma assimetria do desgaste no sentido vertical, o que pode causar uma assimetria do perfil de distribuição. Já os bicos de cerâmica XR e ADI e de aço inox DG tiveram os menores desgastes, para o tempo total do teste. No bico de cerâmica ADI, apesar de ter apenas $10 \%$ de nível de desgaste, nota-se uma diferença no diâmetro menor em relação ao novo. 


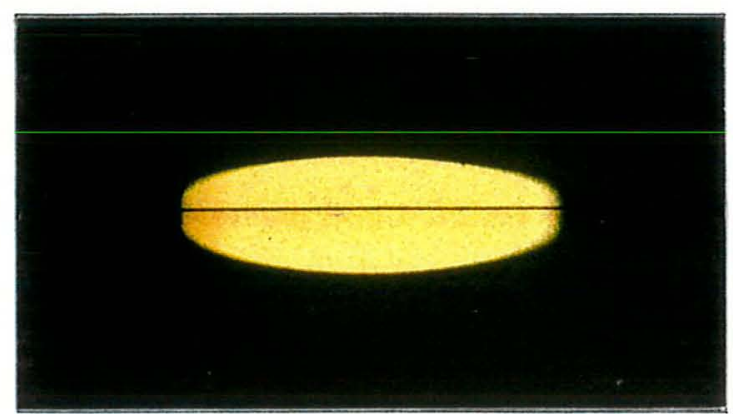

(a) Bico cerâmica XR - Novo

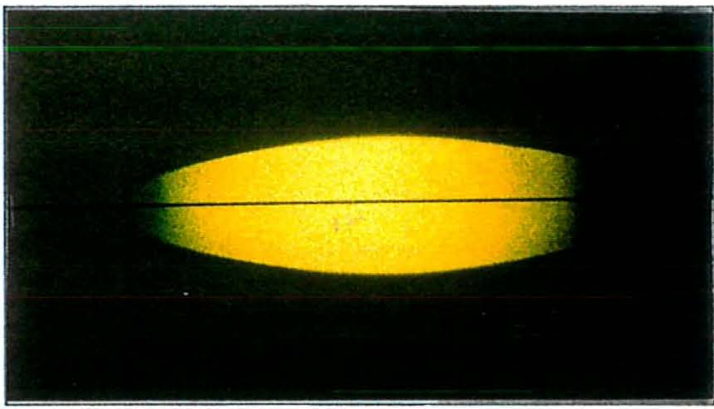

(b) Bico cerâmica ADI - Novo

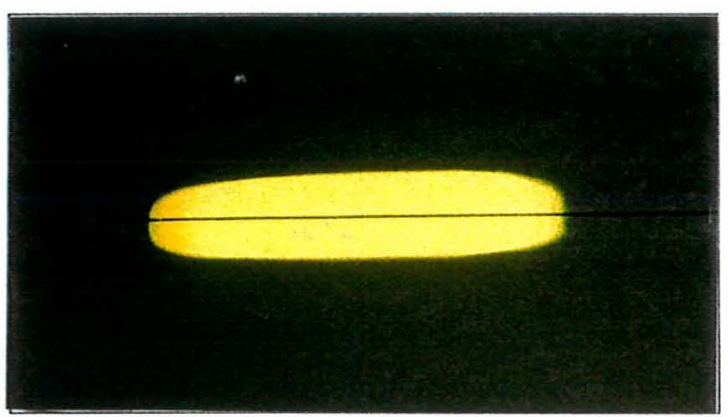

(c) Bico kematal UF - Novo

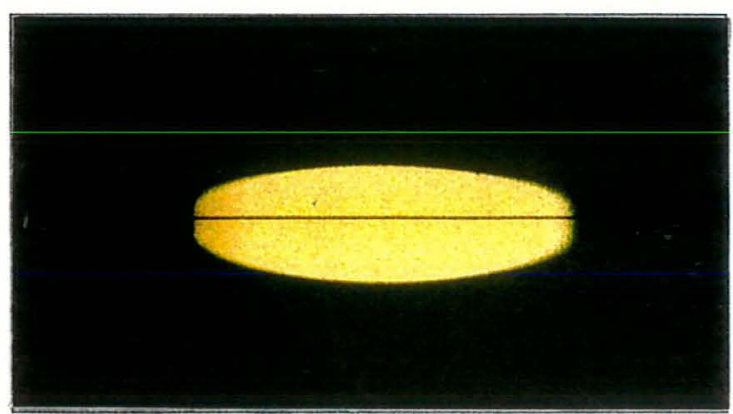

Bico cerâmica XR - Após teste 50 horas - Nível de desgaste $30 \%$

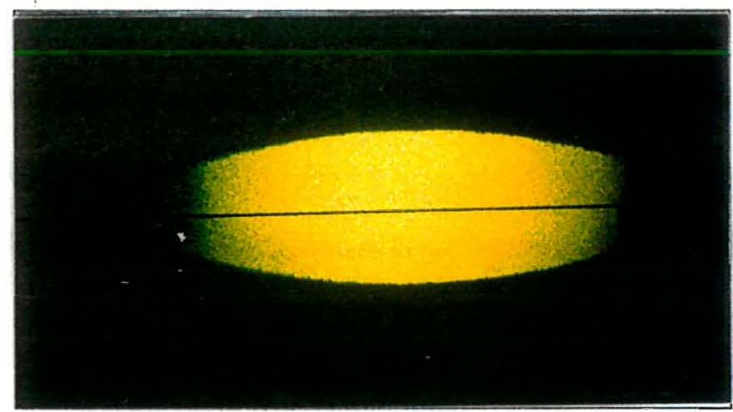

Bico cerâmica $\mathrm{ADI}$ - Após teste 60 horas - Nível de desgaste $10 \%$

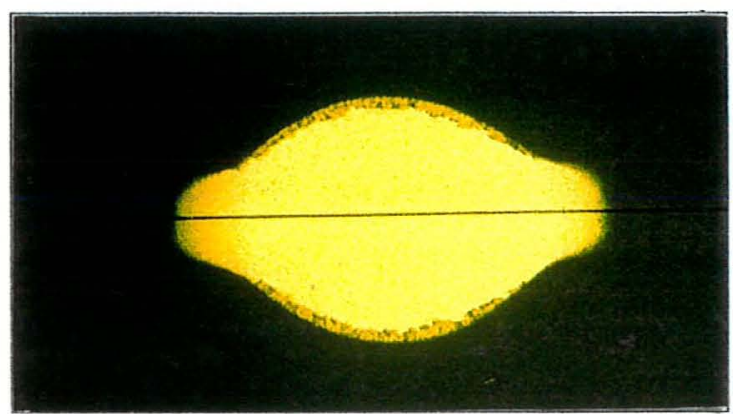

Bico kematal UF - Após teste

3,6 horas - Nível de desgaste $50 \%$

Figura 29. Vista em detalhe do orifício do bico novo e após o teste. (a) cerâmica XR, (b) cerâmica ADI e (c) kematal UF. (Ampliação 20 X) 


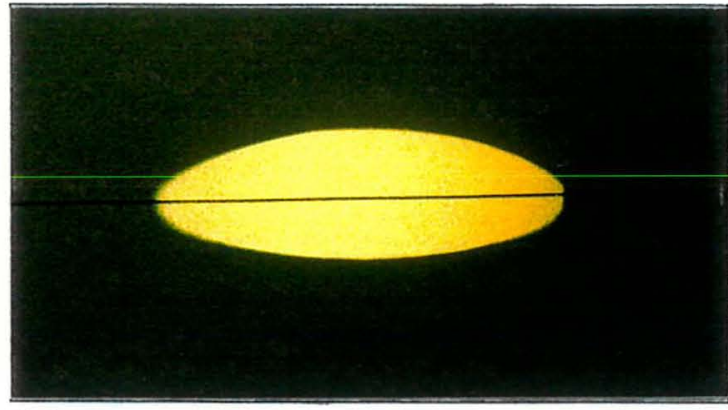

(a) Bico kematal LD - Novo

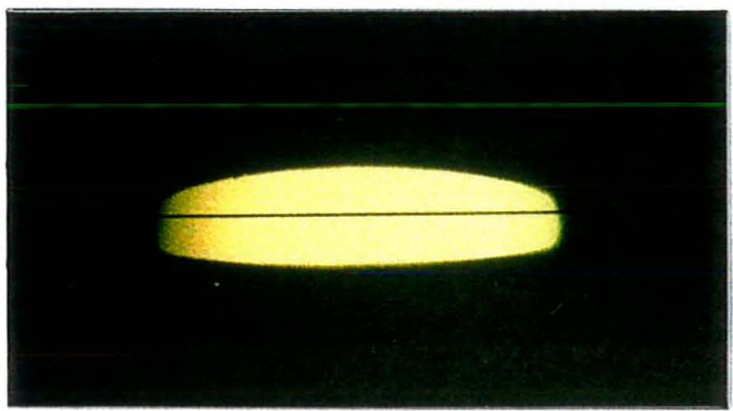

(b) Bico aço inox XR - Novo

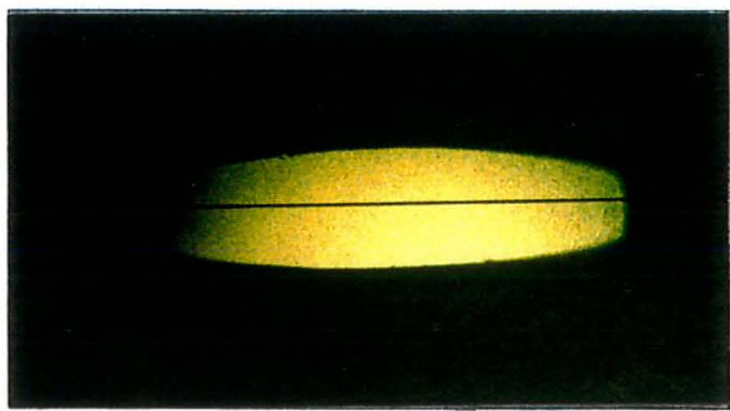

(c) Bico aço inox DG - Novo

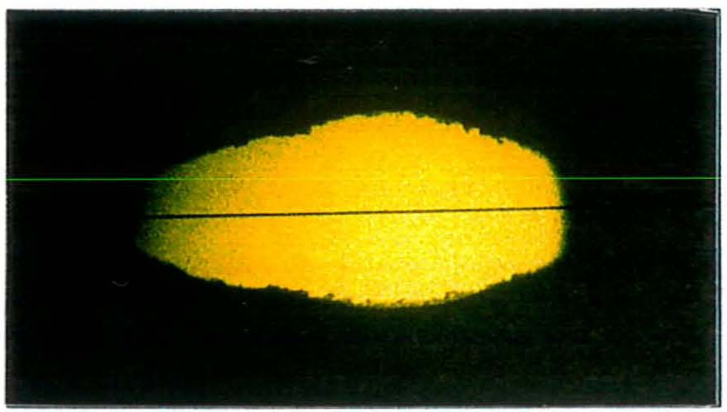

Bico kematal LD - Após teste 4,0 horas - Nível de desgaste $50 \%$

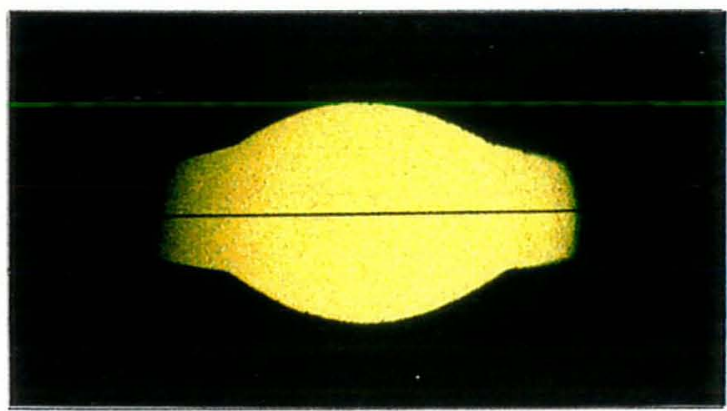

Bico aço inox XR - Após teste 1,6 horas - Nível de desgaste $50 \%$

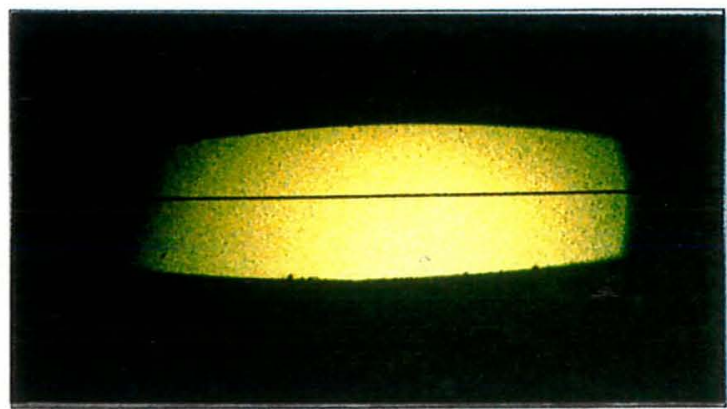

Bico aço inox DG - Após teste 60 horas - Nível de desgaste $30 \%$

Figura 30. Vista em detalhe do orifício do bico novo e após o teste. (a) kematal LD, (b) aço inox XR e (c) aço inox DG. (Ampliação $20 \mathrm{X}$ ) 


\subsubsection{Estudo da uniformidade de distribuição}

O estudo da uniformidade de distribuição teve por objetivo analisar os efeitos do desgaste sob esta característica funcional do bico, que se refere a qualidade da distribuição, enquanto que até então foram estudados os efeitos quantitativos provocados pelo desgaste. Para tanto, foram realizadas avaliações de gráficos, da variação do $\mathrm{CV}$ da uniformidade da distribuição e do comportamento do $\mathrm{CV}$ nas três repetições de cada canaleta para os diferentes níveis de desgaste. Além disso, foram estudados a simetria volumétrica da distribuição e o ângulo do jato para melhor caracterização.

\subsubsection{Avaliação do perfil de distribuição}

Foram coletados valores dos perfis de distribuição para cada uma das três repetições em cada nível de desgaste. A coleta do liquido, para cada um dos bicos, foi interrompida assim que o volume coletado em qualquer um dos tubos atingiu $90 \%$ da sua capacidade (NBR 13769, 1997).

As Figuras 31 a 36 apresentam as curvas de cada um dos bicos nos diferentes níveis de desgaste, sendo estas representadas pelas médias das très repetições para cada canaleta. Observando-se os gráficos das figuras citadas acima, nota-se uma excelente simetria na distribuição do líquido para todos os bicos, mesmo nos altos níveis de desgaste. Verifica-se também que, houve uma diminuição da faixa de deposição, para todos os bicos, à medida que aumentou o nível de desgaste, resultado este, já obtido por diversos autores (Reed \& Ferrazza, 1984; Corrêa, 1988; Ozkan et al.,1992c; Balsari \& Tamagnone, 1995). Os bicos de cerâmica ADI, de kematal LD e de aço inox XR, não apresentaram grandes diferenças na forma do perfil de distribuição para os diferentes niveis de desgaste, o que induz que estes bicos, quando associados em barras, não sofreriam grandes alterações do coeficiente de variação em função do desgaste. 


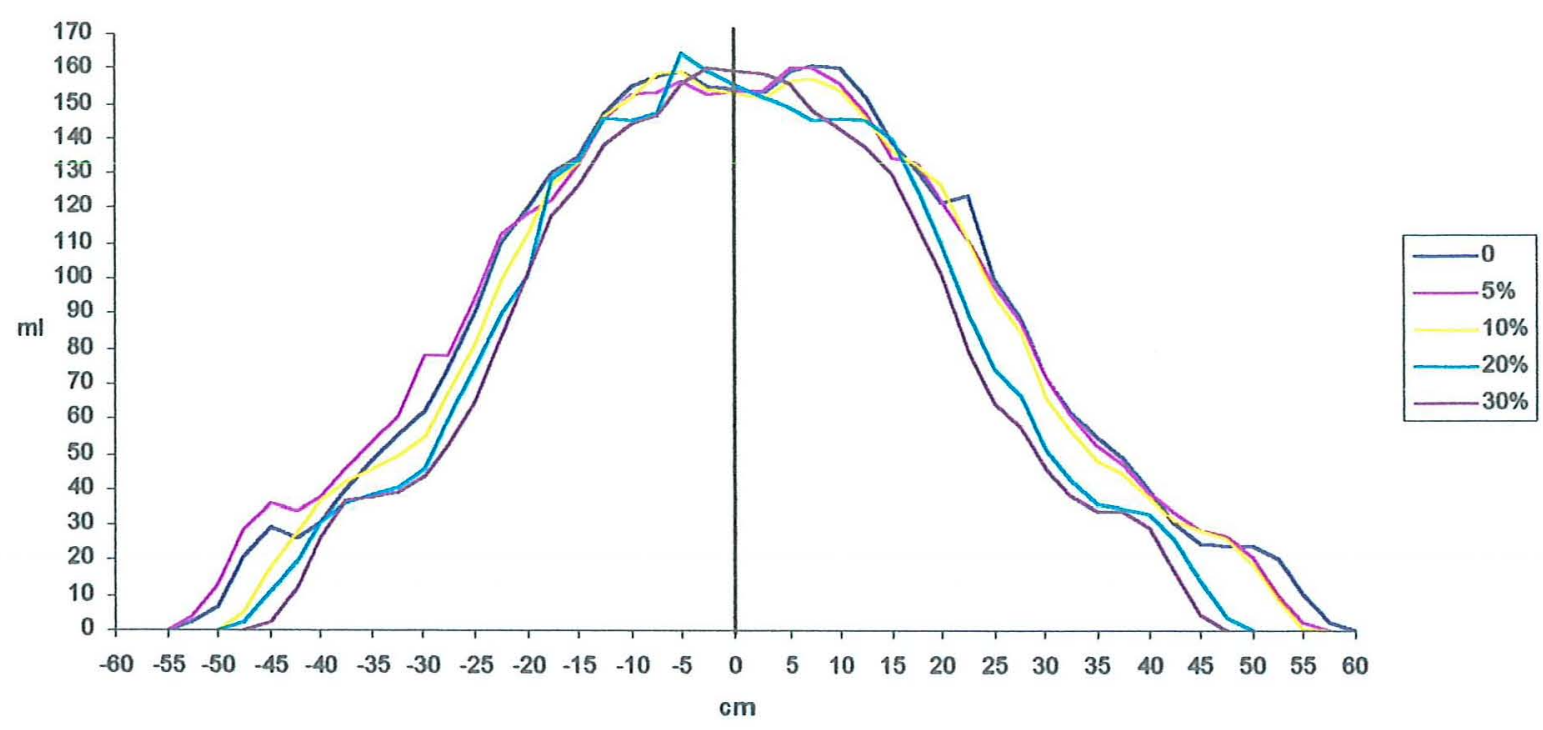

Figura 31. Gráfico do perfil de distribuição do bico de cerâmica XR, nos diferentes níveis de desgaste

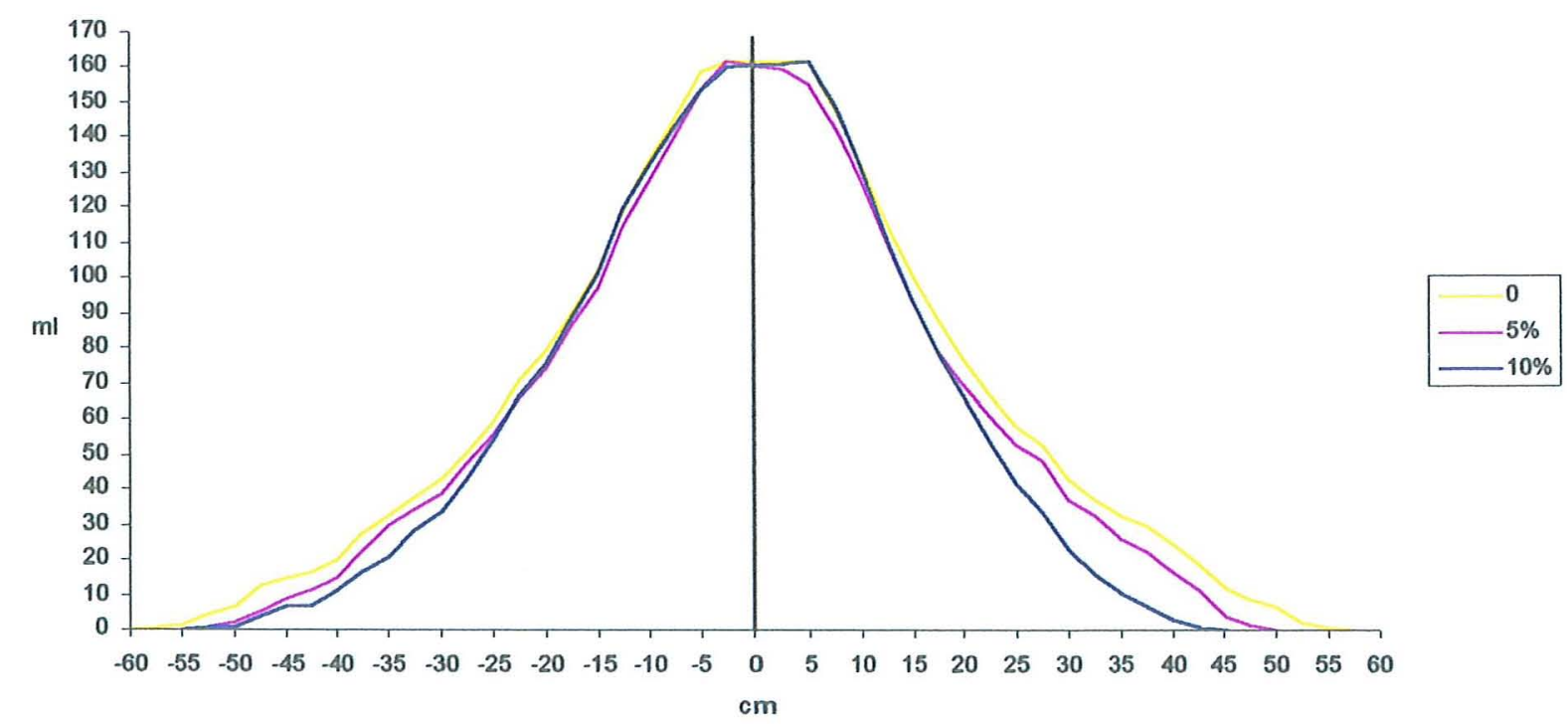

Figigura 32. Gráfico do perfil de distribuição do bico de cerâmica ADI, nos diferentes níveis de desgaste 


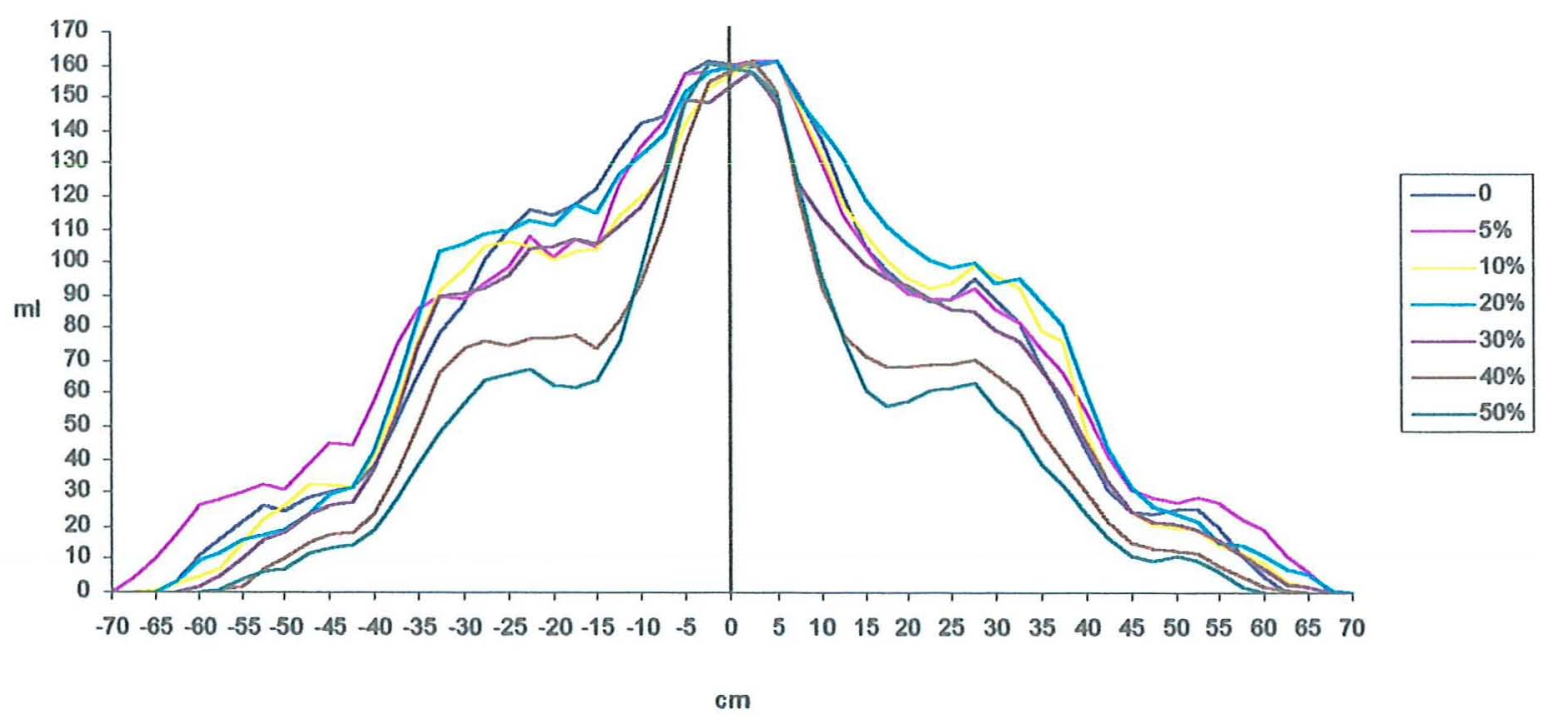

Figura 33. Gráfico do perfil de distribuição do bico de kematal UF, nos diferentes níveis de desgaste

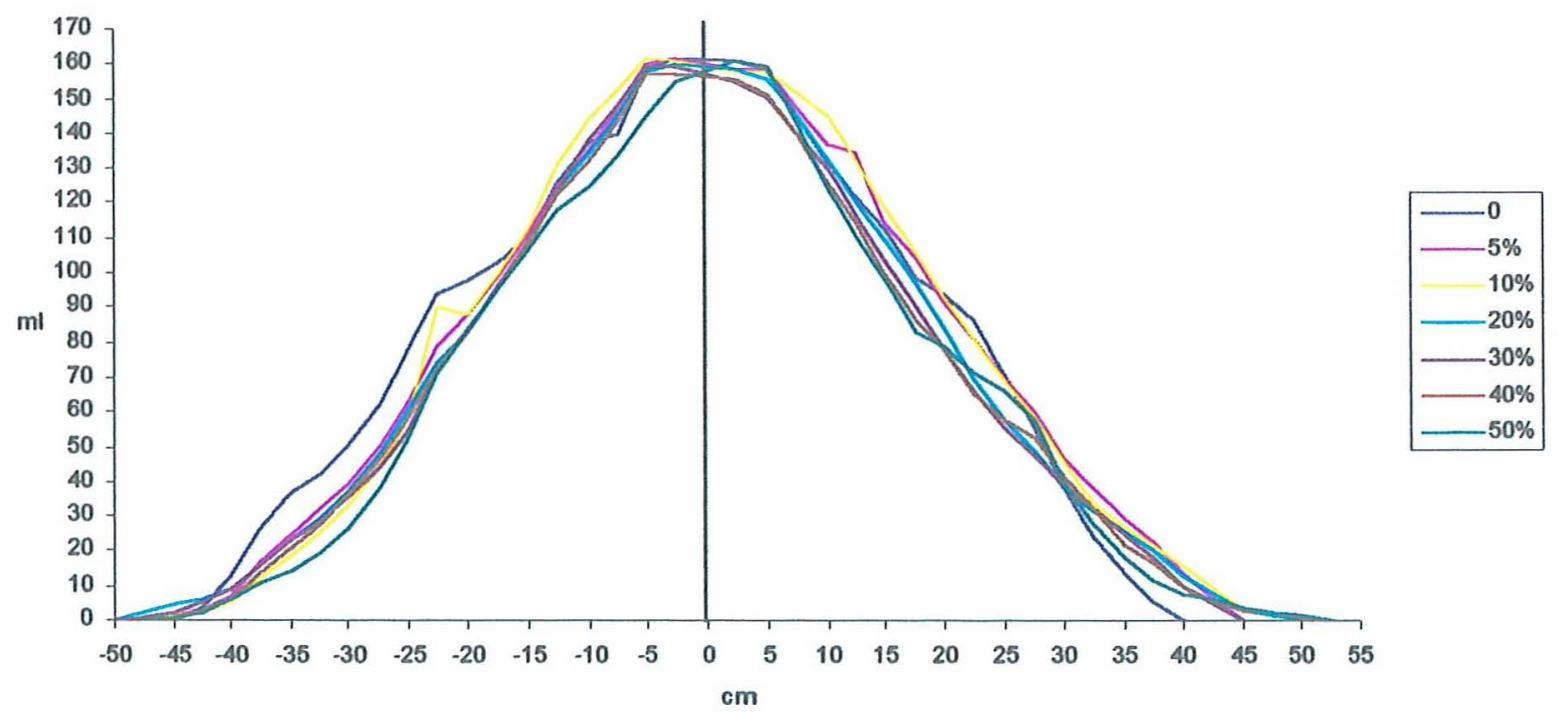

Figura 34. Gráfico do perfil de distribuição do bico de kematal LD, nos diferentes níveis de desgaste 


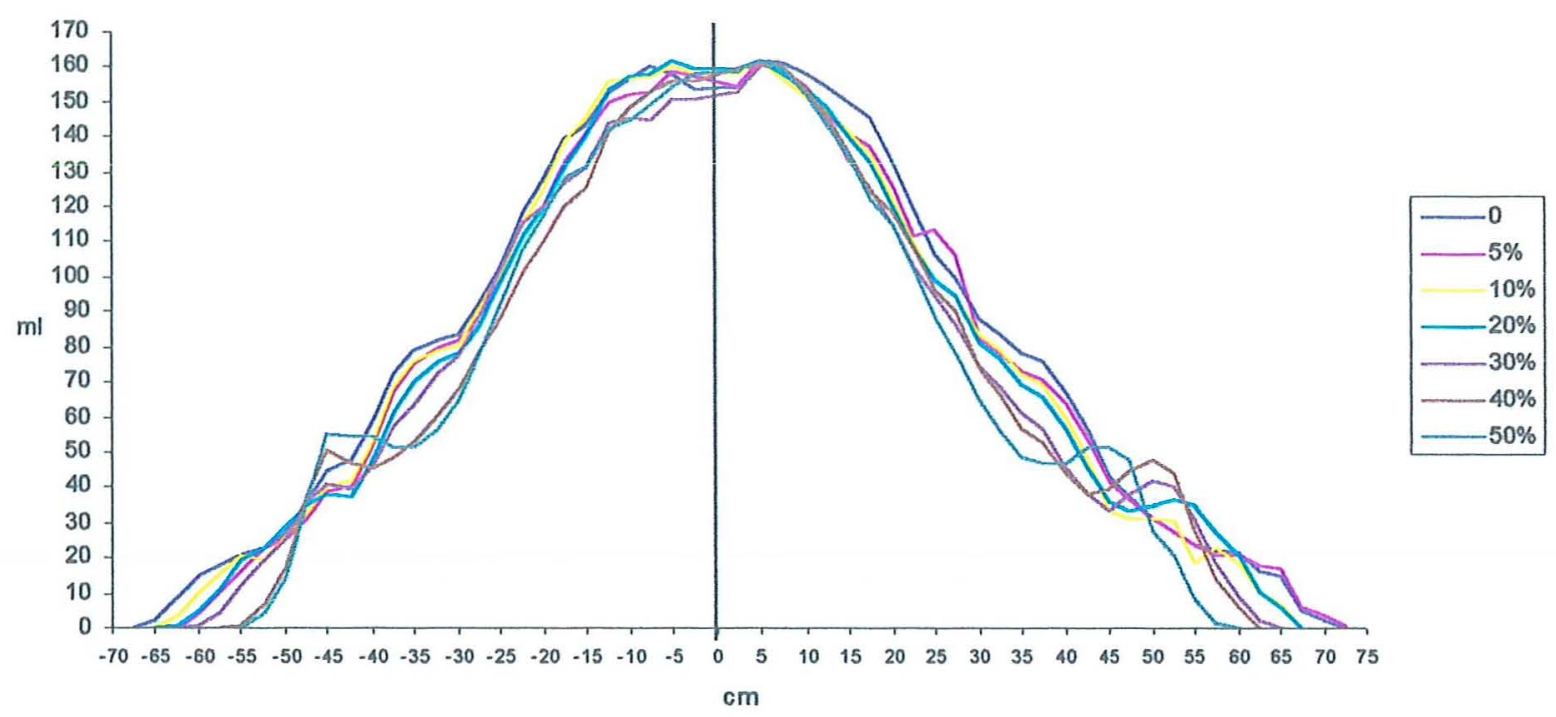

Figura 35. Gráfico do perfil de distribuição do bico de aço inox XR, nos diferentes níveis de desgaste

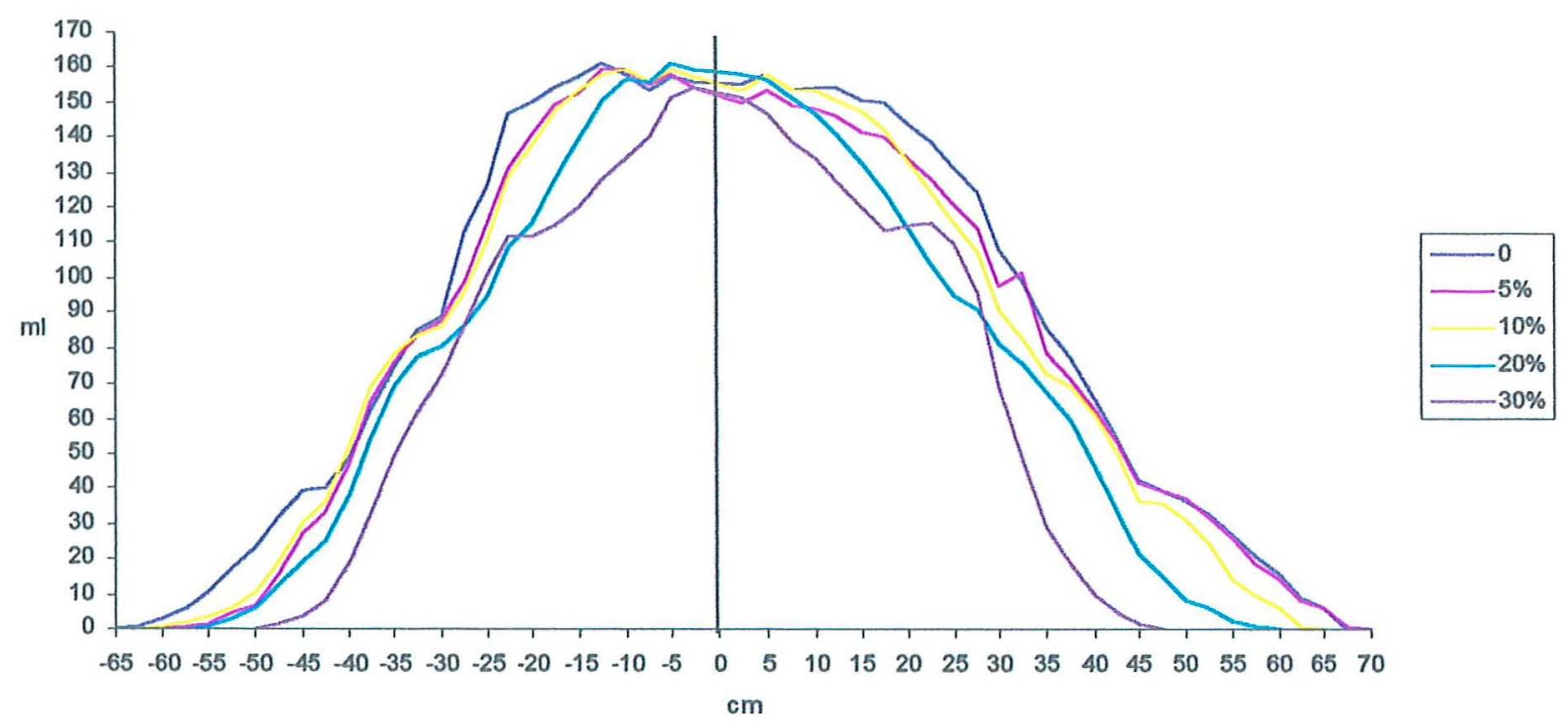

Figura 36. Gráfico do perfil de distribuição do bico de aço inox DG, nos diferentes níveis de desgaste 
O bico de cerâmica XR, apesar de, nos testes ter atingido apenas $30 \%$ do nível de desgaste, teve comportamento dos perfis de distribuição em função no nivel de desgaste bastante variado, com tendência a concentração de líquido no centro do leque. Os bicos de kematal UF e de aço inox DG foram os que revelaram as maiores irregularidades do perfil de distribuição, sendo que o bico de kematal UF, nos niveis de desgaste de 40 e $50 \%$, apresentou grande diferença no perfil de distribuição, diminuindo a faixa de deposição e concentrando o líquido nos $20 \mathrm{~cm}$ centrais.

\subsubsection{Avaliação do CV da uniformidade da distribuição}

A maioria dos autores, segundo Balastreire (1970), são concordantes em considerar que a uniformidade de distribuição é a mais importante caracteristica funcional a ser levada em conta na aplicação de defensivos através de bicos. A maneira usual de expressar a uniformidade de distribuição do líquido pulverizado é o coeficiente de variação. Novak \& Cavaletto (1888), Friesen (1988) e Azime et al. (1985) citam que $\mathrm{CV}$ abaixo de $10 \%$ é aceito como variação normal da distribuição, entre 10 e $15 \%$ é aceitável, e acima de $15 \%$ é inaceitável. Já a entidade de pesquisa Biologische Bundesanstalt Fürland-Und Forstwrts-chaft Bundersrepublik Deutschland (1988), citada por Furlanete (1995), indica um limite do CV de no máximo 7\%. Neste estudo foi calculado o coeficiente de variação, através do perfil de distribuição individual do bico, simulando-o em uma barra de pulverização (Figura 10).

Os resultados mostrados na Tabela 20 e no gráfico da Figura 37, são referentes ao $\mathrm{CV}$ calculado com o perfil médio, para a altura e o espaçamento préfixados nos diferentes níveis de desgaste. Observa-se que o bico de cerâmica XR apresentou um baixo CV (2,37\%) quando novo, elevando-se para $10,28 \%$, quando a vazão atingiu $30 \%$ de aumento, valor este dentro do limite ótimo citado pelos autores acima, significando que, o desgaste até este nivel não provocou irregularidade na distribuição. 
$\mathrm{O}$ bico de cerâmica $\mathrm{ADI}$ mesmo quando novo já apresentou um alto $\mathrm{CV}$ $(16,955)$, subindo para $23,89 \%$ com apenas $10 \%$ de aumento da vazão, sendo o maior valor obtido para todos os CV. Este alto CV inicial induz a crer que o espaçamento e/ou a altura pré-fixadas, apesar de indicadas pelo fabricante, não são as melhores para este bico na pressão utilizada no estudo.

Para o bico de kematal UF o CV sofreu as maiores variações em relação aos demais bicos, apresentando diminuições até $20 \%$ de nivel de desgaste, e elevando-se rapidamente após este nível, chegando ao final do teste com $22,43 \%$. No nível de $40 \%$ o $\mathrm{CV}$ dobrou em relação ao nivel anterior. Este fato pode ser observado também através da irregularidade do perfil de distribuição nos níveis de 40 e $50 \%$ apresentados no gráfico da Figura 33 .

Observando as curvas no gráfico da Figura 37 para os bicos de kematal LD e aço inox XR verifica-se que estas tiveram comportamento semelhante ao longo do teste, concordando com a regularidade apresentada nos perfis de distribuição, mostrados nas Figuras 34 e 35, respectivamente. O bico de aço inox XR apresentou os menores valores e as menores variações do CV mesmo atingindo $50 \%$ de aumento da vazão, tendo em todos os níveis um CV dentro da faixa ótima (Novak \& Cavaletto, 1888; Friesen, 1988; Azime et al., 1985). Este dados discordam dos resultados obtidos Sanders (1981) e Wang et al. (1995), que relatam que os bicos não metálicos (cerâmica e plástico) promoveram maior uniformidade da distribuição que os bicos metálicos.

O bico de aço inox DG teve diminuições do $\mathrm{CV}$ até $20 \%$ de aumento da vazão, semelhantemente ao bico de kematal UF, porém elevou-se bruscamente para $12,33 \%$ quando o nível de desgaste atingiu $30 \%$.

Para o nivel de desgaste de $10 \%$, os bicos de aço inox XR e DG e o bico de kematal UF tiveram distribuições com $\mathrm{CV}$ menor que quando novos, concordando com os resultados obtidos por Ozkan et al.(1992 a). Outra observação foi que $76 \%$ de todas as simulações feitas com os bicos novos e desgastados tiveram $\mathrm{CV}$ menor que $15 \%$, e $62 \%$ dessas simulações tiveram CV menor que $10 \%$. 
Tabela 20. Coeficientes de variação dos seis bicos para diferentes níveis de desgaste (N.D.) para o abrasivo Óxido de Alumínio Branco (FFF)

\begin{tabular}{ccccccc}
\hline N.D. & \multicolumn{7}{c}{ Bicos } \\
\cline { 2 - 7 } & cer. XR & cer. ADI & kem UF & kem LD & aço i. XR & aço i. DG \\
\hline 0 & 2,37 & 16,95 & 9,21 & 9,82 & 5,01 & 7,09 \\
5 & 2,96 & 17,82 & 7,99 & 10,08 & 3,99 & 7,04 \\
10 & 4,75 & 23,89 & 8,84 & 12,22 & 4,25 & 5,76 \\
20 & 8,59 & - & 4,77 & 14,27 & 6,08 & 5,27 \\
30 & 10,28 & - & 8,56 & 15,49 & 7,09 & 12,33 \\
40 & - & - & 17,08 & 15,02 & 9,22 & - \\
50 & - & - & 22,43 & 16,76 & 8,08 & - \\
\hline
\end{tabular}

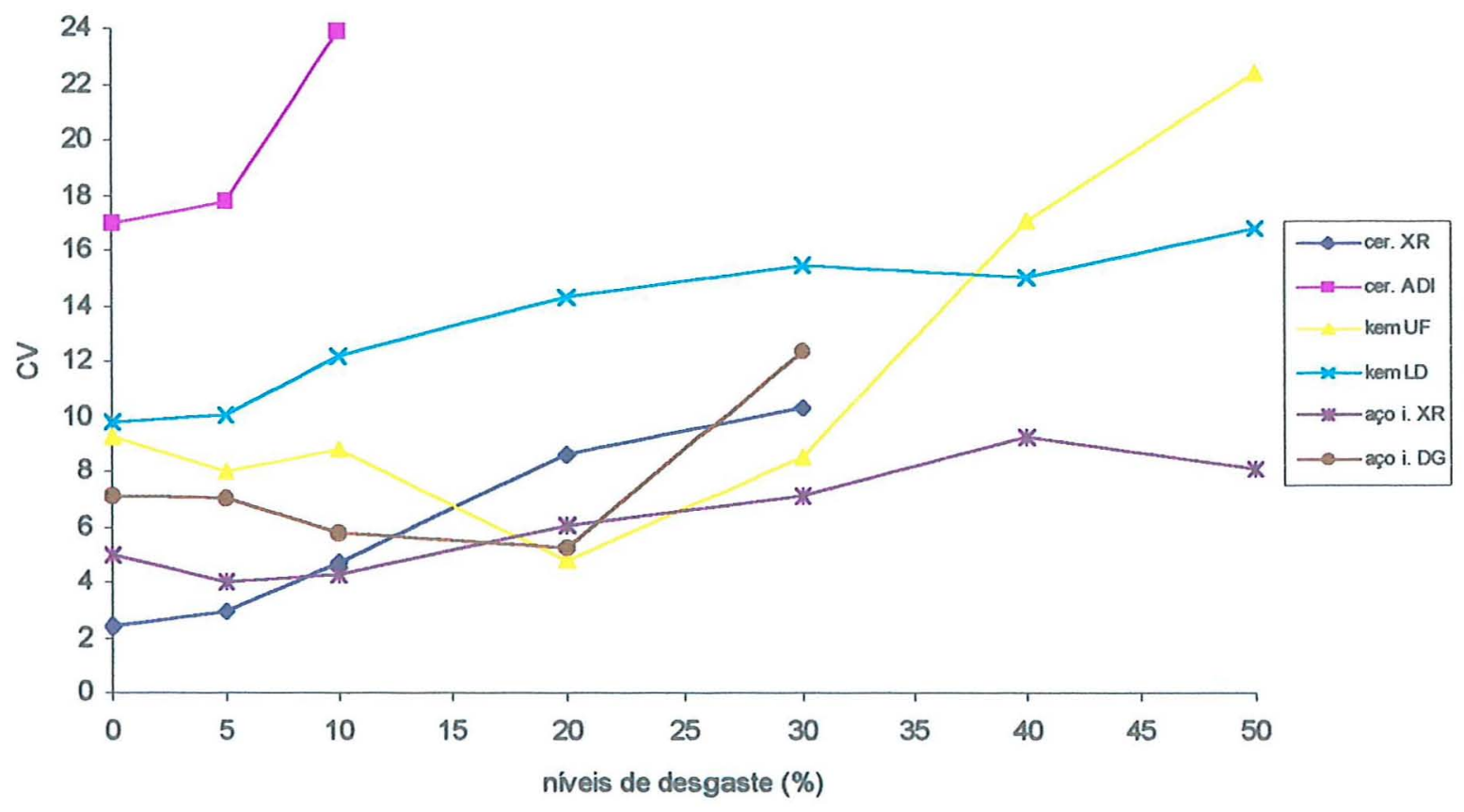

Figura 37. Gráfico da variação do CV em função dos níveis de desgaste para os diferentes bicos. 
A maioria dos fabricantes de bicos pulverizadores (Hard International, 1995; Spraying Systems Co. 1994; Albuz Ceramiques, 1991), utilizam o aumento da vazão como indicador de desgaste de um bico e recomendam que a substituição deste deve ser feita quando a sua vazão exceder a de um bico novo em $10 \%$, justificando que, neste nível, as demais caracteristicas funcionais do bico ( $\mathrm{CV}$ da distribuição, ângulo do jato e tamanho de gota) também tenham se alterado tornando-se intoleráveis. Neste estudo observou-se que, de modo geral, um aumento de até $10 \%$ de aumento da vazão dos bicos confeccionados nos diferentes materiais, não provocou grande diferença no $\mathrm{CV}$, ficando este dentro do intervalo aceitável, sendo este resultado concordante com vários pesquisadores (Sintorn, 1982; Marques et al., 1988; Novak \& Cavaletto, 1988; Friesen, 1988; Ozkan et al., 1992 b; Ozkan et al., 1992 c; Rice, 1993), contudo discorda dos resultados obtidos por Barrufet et al.(1989). Em virtude disso Ozkan et al.(1991) sugeriu que futuras pesquisas fossem feitas investigando o efeito do desgaste na mudança do perfil de distribuição e, também, do tamanho de gotas, para níveis de desgaste de até $50 \%$, a fim de estabelecer quando estes parâmetros se tornam intoleráveis e quando os bicos devem ser substituídos.

A Figura 38 mostra os gráficos do comportamento dos aumentos porcentuais da vazão e do $\mathrm{CV}$ em função do tempo de desgaste para cada um dos bicos estudados. Os bicos de kematal LD e de aço inox XR tiveram altos índices de aumento da vazão, porém o CV manteve-se praticamente constante, o que significa que apesar do alto nivel de desgaste, a distribuição do líquido manteve-se uniforme ao longo da barra. O bico de kematal UF após o nível de desgaste de $20 \%$, mostra índices de aumento semelhantes para a vazão e $\mathrm{CV}$, semelhantemente ao bico de aço inox DG. O bico de cerâmica $\mathrm{ADI}$ apesar de não apresentar aumento da vazão, tendo atingido apenas $10 \%$ com 60 horas de teste, revelou altos valores de CV, ficando estes acima dos valores da vazão. Para o bico de cerâmica XR os índices de aumento do $\mathrm{CV}$ são menores que os índices de aumento da vazão

Neste estudo de avaliação do $\mathrm{CV}$ da uniformidade de distribuição constatou-se que os bicos tiveram comportamentos variados independente do material de confecção e do tipo do bico, impossibilitando ordenar os bicos quanto ao desempenho. 


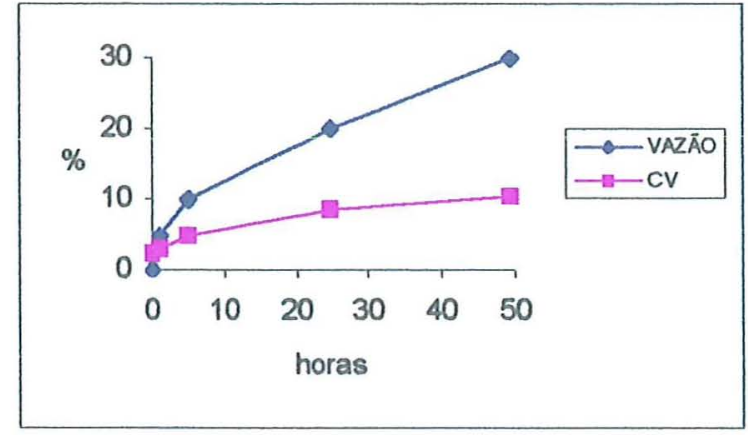

(a)

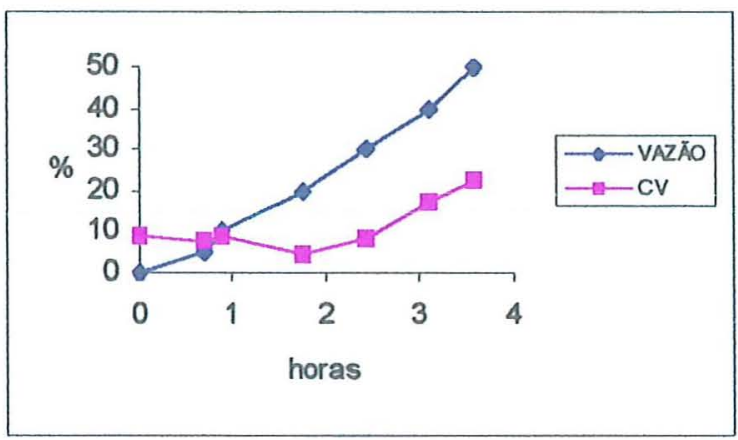

(c)

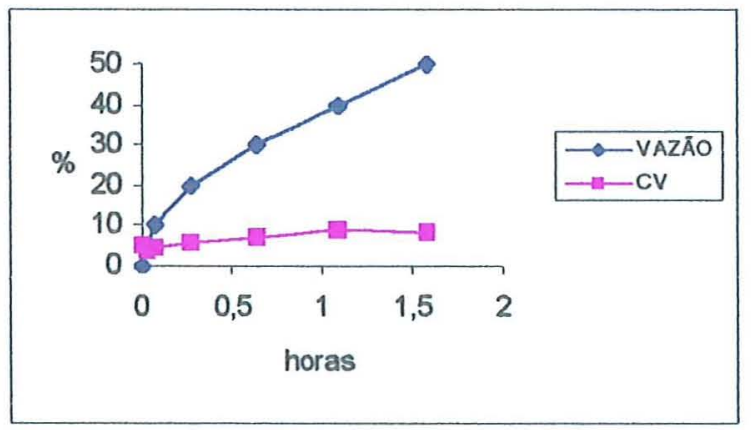

(e)

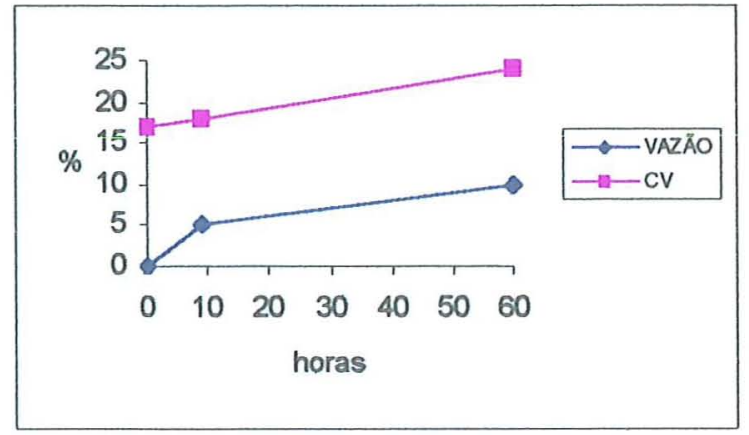

(b)

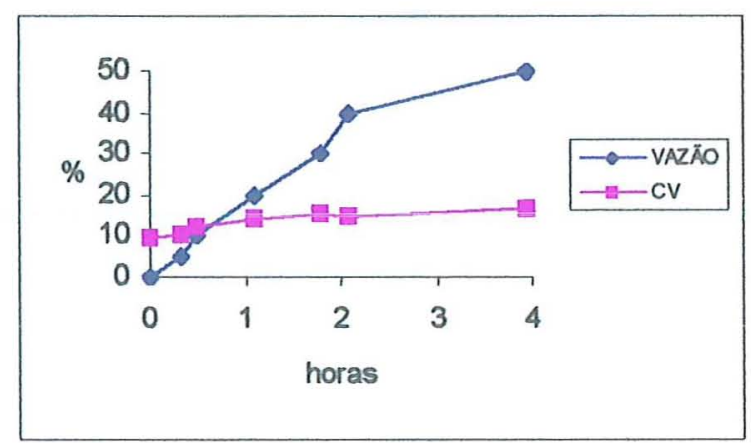

(d)

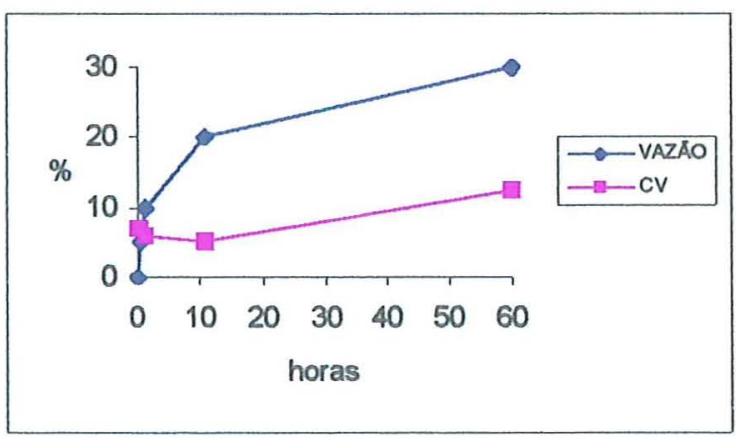

(if)

Figura 38. Comportamento dos aumentos porcentuais da vazão e do CV em função do tempo de desgaste, para os bicos: cerâmica XR (a), cerâmica ADI (b), kematal UF (c), kematal LD (d), aço inox XR (e) e aço inox DG (f). 


\subsubsection{Comportamento do CV para cada canaleta nos diferentes niveis de desgaste}

Os gráficos da Figura 39 têm por objetivo mostrar o coeficiente de variação obtido das três repetições de cada uma das canaletas nos diferentes níveis de desgaste, a fim de se avaliar a regularidade do perfil de distribuição entre as repetições, verificando-se a confiabilidade nas médias obtidas para a determinação do $\mathrm{CV}$ da uniformidade de distribuição, conforme a Norma NBR 13769 (1997).

Relacionando as Figuras 33 e 36 com as Figuras 39 (c) e 39 (f), respectivamente, verifica-se que os bicos referentes as primeiras figuras apresentaram as maiores irregularidades do perfil de distribuição entre os níveis de desgaste. Irregularidades estas também ocorridas no comportamento do $\mathrm{CV}$ das três repetições de cada canaleta para estes mesmos bicos. Isto significa que os bicos de kematal UF e de aço inox DG, cujo desgaste provocou grandes alterações no perfil de distribuição médio, também apresentaram as maiores diferenças nos perfis de distribuição individuais das repetições, notados pelos altos $\mathrm{CV}$ das três repetições.

Para três dos seis bicos estudados, os $\mathrm{CV}$ das repetições das canaletas centrais mostraram-se abaixo de 10\%, conforme Figura 39 (a), (b) e (e). Enquanto que nos demais bicos, os CV estiveram ao redor de $20 \%$. Nota-se que, para todos os bicos e em todos os níveis de desgaste, os $\mathrm{CV}$ das últimas canaletas laterais aumentaram bruscamente, o que é explicado estatisticamente pelos baixos valores das médias nessas canaletas, em relação ao desvio padrão, que praticamente não se alterou ao longo das canaletas. Sugere-se nesse caso, a utilização do desvio padrão como medida da diferença entre os volumes das canaletas na repetições, ao em vez do $\mathrm{CV}$, pois representaria esta diferença independentemente do volume médio. Além disso, o desvio padrão mediria melhor, pelo fato de utilizar a mesma unidade do fator variante (volume). 


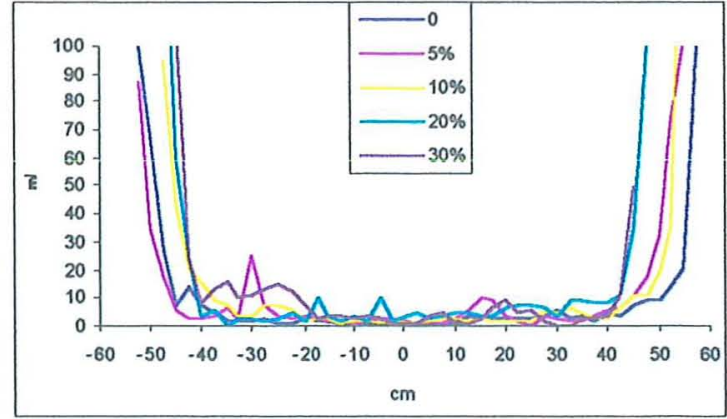

(a)

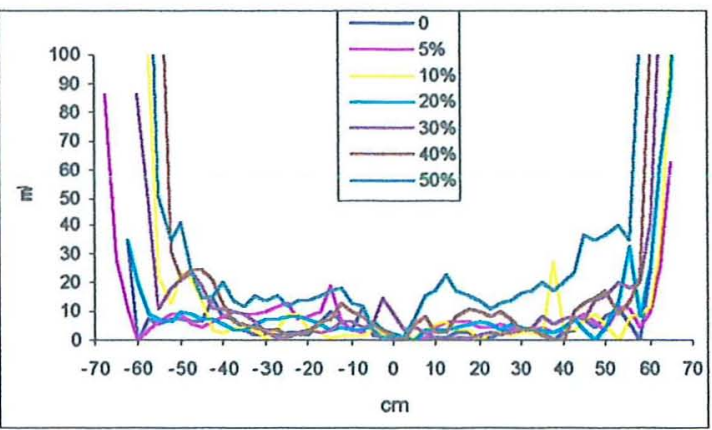

(c)

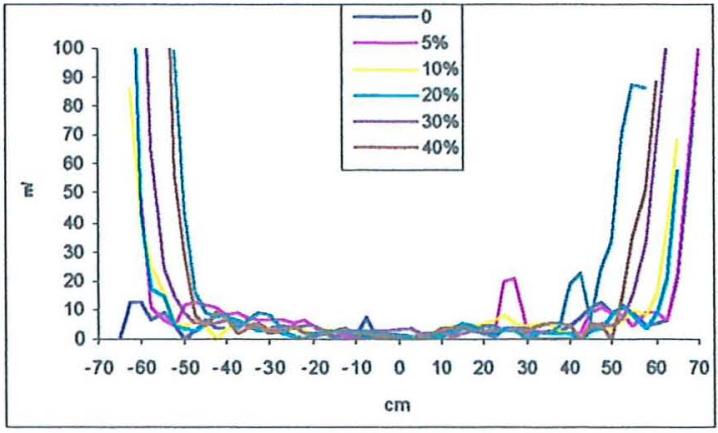

(e)

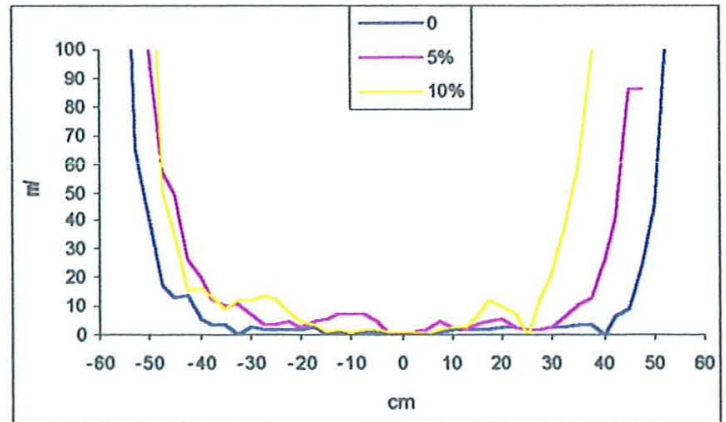

(b)

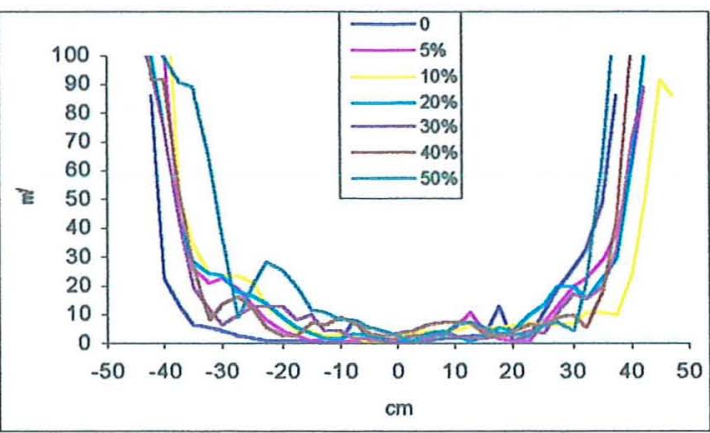

(d)

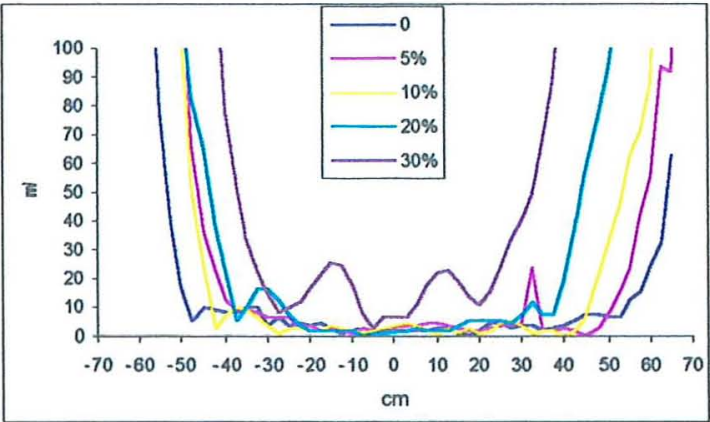

(f)

Figura 39. Comportamento do CV das três repetições de cada canaleta para os diferentes níveis de desgaste, para os bicos: cerâmica XR (a), cerâmica ADI (b), kematal UF (c), kematal LD (d), aço inox XR (e) e aço inox DG (f). 


\subsubsection{Avaliação da simetria volumétrica da distribuição}

As Tabelas 21 a 26 mostram para cada bico, a distribuição da vazão (ml) para os lados direito e esquerdo, a diferença porcentual, o volume médio total e o tempo médio de coleta, nos diferentes niveis de desgaste. Esta avaliação têm por objetivo mostrar as diferenças volumétricas entre os lados para cada repetição, a fim verificar a simetria quantitativa do perfil de distribuição, garantindo confiabilidade nas médias obtidas para a determinação do CV da uniformidade de distribuição, conforme a Norma NBR 13769 (1997).

O volume total calculado pela soma do volume médio dos lados direito e esquerdo apresentou sensíveis diminuições dos valores com aumento do nível de desgaste. Isto confirma os resultados da diminuição da faixa de deposição mostrada nos gráficos do perfil de distribuição. Essa diminuição do volume ocorreu devido ao líquido se concentrar mais no centro do perfil atingindo, mais rapidamente, a altura pré-fixada no tubo coletor. Isto explica também, a diminuição do tempo de coleta do líquido na mesa de canaleta à medida em que aumentou o nível de desgaste.

As diferenças porcentuais volumétricas entre os lados foram baixas, sendo o maior valor nas repetições igual a 15,24\%, e nas médias igual a 10,23\%, ocorridas para o bico de cerâmica ADI com 10\% de nível de desgaste. Do total de medições realizadas, apenas 14,0\% apresentaram diferenças entre os lados, superiores a $10 \%$, sendo que, o bico de kematal LD apresentou o maior número desses valores, em relação aos demais bicos. Notou-se também, que as maiores diferenças porcentuais se mostraram dispersas em relação aos diferentes niveis de desgaste, material de confecção e tipo de bico.

As diferenças medidas em cada repetição para um mesmo nível de desgaste, se ocorrerem sempre de um mesmo lado, indicarão que não há grandes diferenças entre as repetições e, consequentemente, a média estará bem representada. Contudo, se estas diferenças ocorrerem em lados alternados nas repetições, indicarão a presença de compensações entre os perfis das repetições, causando um perfil médio regular, porém não representativo. 
Tabela 21. Distribuição da vazão (ml) para os lados direito e esquerdo, diferença porcentual, volume médio total e tempo médio de coleta para o bico de cerâmica XR, nos diferentes níveis de desgaste

Nível de Desgaste

\begin{tabular}{|c|c|c|c|c|c|c|c|c|}
\hline Rep. & Lado & 0 & 5 & 10 & 20 & 30 & 40 & 50 \\
\hline \multirow{3}{*}{1} & Esquerdo & 1773,2 & 1826,9 & 1721,9 & 1634,5 & 1564,2 & & \\
\hline & Direito & 1843.6 & 1836.0 & 1803.7 & 1533,8 & 1524,3 & & \\
\hline & Dif. (\%) & 3,81 & 0,50 & 4,53 & 6,16 & 2,55 & & \\
\hline \multirow{3}{*}{2} & Esquerdo & 1767,6 & 1811,3 & 1670,6 & 1529,9 & 1438,7 & & \\
\hline & Direito & 1904,4 & 1843,6 & 1826,5 & 1573,7 & 1474,8 & & \\
\hline & Dif. (\%) & 7,19 & 1,75 & 8,53 & 2,78 & 2,45 & & \\
\hline \multirow{3}{*}{3} & Esquerdo & 1737,1 & 1794,2 & 1625,0 & 1564,2 & 1469,1 & & \\
\hline & Direito & 1934,8 & 1904,4 & 1834,0 & 1649,7 & 1480,6 & & \\
\hline & Dif. $(\%)$ & 10,22 & 5,79 & 11,40 & 5,18 & 0,77 & & \\
\hline \multirow{3}{*}{ Média } & Esquerdo & 1759,3 & 1810,8 & 1672,5 & 1576,2 & 1490,7 & & \\
\hline & Direito & 1894,3 & 1861,4 & 1821,4 & 1585,7 & 1493,2 & & \\
\hline & Dif. (\%) & 7,12 & 2,72 & 8,17 & 0,60 & 0,17 & & \\
\hline \multicolumn{2}{|c|}{ Volume Total } & 3653,6 & 3672,2 & 3493,9 & 3161,9 & 2983,9 & & \\
\hline \multicolumn{2}{|c|}{ Tempo de Coleta } & 3,20 & 3,06 & 2,78 & 2,31 & 2,01 & & \\
\hline
\end{tabular}

Tabela 22. Distribuição da vazão (ml) para os lados direito e esquerdo, diferença porcentual, volume médio total e tempo médio de coleta para o bico de cerâmica $\mathrm{ADI}$, nos diferentes níveis de desgaste

Nível de Desgaste

\begin{tabular}{|c|c|c|c|c|c|c|c|c|}
\hline Rep. & Lado & 0 & 5 & 10 & 20 & 30 & 40 & 50 \\
\hline \multirow{3}{*}{1} & Esquerdo & 1417.8 & 1366.5 & 1309.5 & & & & \\
\hline & Direito & 1391,2 & 1263,9 & 1109,9 & & & & \\
\hline & Dif. (\%) & 1,88 & 7,51 & 15,24 & & & & \\
\hline \multirow{3}{*}{2} & Esquerdo & 1370,3 & 1282,9 & 1279,1 & & & & \\
\hline & Direito & 1376,0 & 1212,6 & 1157,5 & & & & \\
\hline & Dif. $(\%)$ & 0,41 & 5,48 & 9,51 & & & & \\
\hline \multirow{3}{*}{3} & Esquerdo & 1389.3 & 1223,9 & 1220.2 & & & & \\
\hline & Direito & 1370,3 & 1273.4 & 1151,8 & & & & \\
\hline & Dif. (\%) & 1,37 & 3,88 & 5,61 & & & & \\
\hline \multirow{3}{*}{ Média } & Esquerdo & 1392,5 & 1291,1 & 1269,6 & & & & \\
\hline & Direito & 1379,2 & 1249,9 & 1139,7 & & & & \\
\hline & Dif. (\%) & 0,96 & 3,19 & 10,23 & & & & \\
\hline \multicolumn{2}{|c|}{ Volume Total } & 2771,7 & 2541 & 2409,3 & & & & \\
\hline \multicolumn{2}{|c|}{ Tempo de Coleta } & 2,37 & 2,07 & 1,87 & & & & \\
\hline Dife & & os lac & 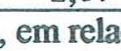 & , & & & & \\
\hline
\end{tabular}


Tabela 23. Distribuição da vazão (ml) para os lados direito e esquerdo, diferença porcentual, volume médio total e tempo médio de coleta para o bico de kematal UF, nos diferentes níveis de desgaste

Niveis de Desgaste

\begin{tabular}{rlrrrrrrr}
\hline Rep. & Lado & \multicolumn{1}{c}{0} & \multicolumn{1}{c}{5} & \multicolumn{1}{c}{10} & \multicolumn{1}{c}{20} & \multicolumn{1}{c}{30} & \multicolumn{1}{c}{40} & \multicolumn{1}{c}{50} \\
\hline \multirow{2}{*}{1} & Esquerdo & 2001,3 & 2187,6 & 1799,8 & 1913,9 & 1784,6 & 1419,7 & 1307,6 \\
& Direito & 1828,4 & 1934,8 & 1879,7 & 1982,3 & 1630,7 & 1385,5 & 1278,5 \\
& Dif. (\%) & 8,64 & 11,56 & 4,25 & 3,45 & 8,63 & 2,41 & 2,18 \\
\hline \multirow{2}{*}{2} & Esquerdo & 1904,4 & 1953,8 & 1797,9 & 1898,7 & 1737,1 & 1269,6 & 1328,5 \\
& Direito & 1780,8 & 1864,5 & 1813,1 & 1946,2 & 1718,1 & 1347,5 & 1376,0 \\
& Dif. (\%) & 6,49 & 4,57 & 0,84 & 2,44 & 1,09 & 5,78 & 3,45 \\
\hline \multirow{2}{*}{3} & Esquerdo & 1898,7 & 1972,8 & 1856,8 & 2024,1 & 1695,3 & 1387,4 & 1092,8 \\
& Direito & 1792,3 & 1849,3 & 1889,2 & 2065,9 & 1699,1 & 1339,9 & 1043,4 \\
& Dif. (\%) & 5,61 & 6,26 & 1,71 & 2,02 & 0,22 & 3,42 & 4,52 \\
\hline \multirow{2}{*}{ Média } & Esquerdo & 1934,8 & 2038,0 & 1818,2 & 1945,6 & 1739,0 & 1358,9 & 1243,0 \\
& Direito & 1800,5 & 1882,8 & 1860,7 & 1998,1 & 1682,6 & 1357,7 & 1232,9 \\
& Dif. (\%) & 6,94 & 7,62 & 2,28 & 2,63 & 3,24 & 0,09 & 0,82 \\
\hline Volume Total & 3735,3 & 3920,8 & 3678,9 & 3943,7 & 3421,6 & 2716,6 & 2475,9 \\
\hline \multicolumn{2}{l}{ Tempo de Coleta } & 3,28 & 3,28 & 2,94 & 2,87 & 2,30 & 1,70 & 1,45 \\
\hline
\end{tabular}

* Diferença porcentual entre os lados, em relação ao maior valor (cor azul)

** Tempo de coleta estimado (min) através do volume médio total e da vazão média

Tabela 24. Distribuição da vazão (ml) para os lados direito e esquerdo, diferença porcentual, volume médio total e tempo médio de coleta para o bico de kematal LD, nos diferentes níveis de desgaste

Níveis de Desgaste

\begin{tabular}{|c|c|c|c|c|c|c|c|c|}
\hline Rep. & Lado & 0 & 5 & 10 & 20 & 30 & 40 & 50 \\
\hline \multirow{3}{*}{1} & Esquerdo & 1438.76 & 1315,2 & 1425.4 & 1358,9 & 1313,3 & 1300,0 & 1161,3 \\
\hline & Direito & 1351,3 & 1490.0 & 1417,8 & 1330,4 & 1271,5 & 1235,3 & 1244.9 \\
\hline & Dif. (\%) & 6,08 & 11,73 & 0,53 & 2,10 & 3,18 & 4,98 & 6,72 \\
\hline \multirow{3}{*}{2} & Esquerdo & 1452,0 & 1431,1 & 1275,3 & 1222,1 & 1212,6 & 1235,4 & 1288,6 \\
\hline & Direito & 1290,5 & 1370,3 & 1385,5 & 1379.8 & 1258.2 & 1349.4 & 1362,7 \\
\hline & Dif. $(\%)$ & 11,13 & 4,25 & 7,96 & 11,43 & 3,63 & 8,45 & 5,44 \\
\hline \multirow{3}{*}{3} & Esquerdo & 1436.8 & 1290,5 & 1330,4 & 1374,1 & 1404,6 & 1328,5 & 1165,0 \\
\hline & Direito & 1311,4 & 1379.8 & 1488.1 & 1252,5 & 1258,2 & 1193,6 & 1204.9 \\
\hline & Dif. (\%) & 8,73 & 6,47 & 10,60 & 8,85 & 10,42 & 10,16 & 3,31 \\
\hline \multirow{3}{*}{ Média } & Esquerdo & 1442,6 & 1345,6 & 1343,7 & 1318,4 & 1310.1 & 1287.9 & 1204,9 \\
\hline & Direito & 1317,7 & 1413,4 & 1430,5 & 1320.9 & 1262,6 & 1259,5 & 1270,9 \\
\hline & Dif. (\%) & 8,65 & 4,80 & 6,07 & 0,19 & 3,63 & 2,21 & 5,18 \\
\hline \multicolumn{2}{|c|}{ Volume Total } & 2760,3 & 2759 & 2774,2 & 2639,3 & 2572,7 & 2547,4 & 2475,8 \\
\hline \multicolumn{2}{|c|}{ Tempo de Coleta } & 2,33 & 2,22 & 2,13 & 1,86 & 1,67 & 1,54 & 1,39 \\
\hline
\end{tabular}


Tabela 25. Distribuição da vazão ( $\mathrm{ml}$ ) para os lados direito e esquerdo, diferença porcentual, volume médio total e tempo médio de coleta para o bico de aço inox XR, nos diferentes níveis de desgaste

Nível de Desgaste

\begin{tabular}{|c|c|c|c|c|c|c|c|c|}
\hline Rep. & Lado & 0 & 5 & 10 & 20 & 30 & 40 & 50 \\
\hline \multirow{3}{*}{1} & Esquerdo & 2170,5 & 2086,9 & 2100,1 & 2006,3 & 1972,8 & 1786,5 & 1898.7 \\
\hline & Direito & 2235.1 & 2166.7 & 2155.3 & 2094,5 & 2003,2 & 1942,4 & 1885,4 \\
\hline & Dif. (\%) & 2,89 & 3,68 & 2,56 & 4,21 & 1,52 & 8,02 & 0,70 \\
\hline \multirow{3}{*}{2} & Esquerdo & 2088,7 & 1965,2 & 2037,4 & 1972,8 & 1872,1 & 1832,1 & 1828,4 \\
\hline & Direito & 2195,6 & 2119,1 & 2041,2 & 2079.2 & 1961.4 & 2041,2 & 1896,8 \\
\hline & Dif. $(\%)$ & 4,86 & 7,26 & 0,19 & 5,12 & 4,55 & 10,24 & 3,61 \\
\hline \multirow{3}{*}{3} & Esquerdo & 2113,8 & 1978,5 & 2083,0 & 2054,5 & 1896,8 & 1820,7 & 1809,4 \\
\hline & Direito & 2282,6 & 2273,1 & 2086,9 & 2155,3 & 2003,2 & 2048,8 & 1879,7 \\
\hline & Dif. $(\%)$ & 7,39 & 12,96 & 0,18 & 4,67 & 5,31 & 11,13 & 3,74 \\
\hline \multirow{3}{*}{ Média } & Esquerdo & 2124,4 & 2010,2 & 2073,5 & 2011,2 & 1913,9 & 1813,1 & 1845,5 \\
\hline & Direito & 2237,7 & 2186,3 & 2094,5 & 2109,7 & 1989,3 & 2010,8 & 1887,3 \\
\hline & Dif. $(\%)$ & 5,07 & 8,06 & 1,00 & 4,67 & 3,79 & 9,83 & 2,22 \\
\hline \multicolumn{2}{|c|}{ Volume Total } & 4362,1 & 4196,5 & 4168 & 4120,9 & 3903,2 & 3823,9 & 3732,8 \\
\hline \multicolumn{2}{|c|}{ Tempo de Coleta } & 3,72 & 3,39 & 3,22 & 2,92 & 2,55 & 2,33 & 2,11 \\
\hline
\end{tabular}

Tabela 26. Distribuição da vazão $(\mathrm{ml})$ para os lados direito e esquerdo, diferença porcentual, volume médio total e tempo médio de coleta para o bico de aço inox DG, nos diferentes níveis de desgaste

Nível de Desgaste

\begin{tabular}{|c|c|c|c|c|c|c|c|c|}
\hline Rep. & Lado & 0 & 5 & 10 & 20 & 30 & 40 & 50 \\
\hline \multirow{3}{*}{1} & Esquerdo & 2168,9 & 2031,7 & 2056,4 & 1839,8 & 1841,7 & & \\
\hline & Direito & 2311.1 & 2197.1 & 2062.1 & 1771,3 & 1786,5 & & \\
\hline & Dif. (\%) & 6,15 & 7,53 & 0,28 & 3,72 & 2,99 & & \\
\hline \multirow{3}{*}{2} & Esquerdo & 2119,2 & 1970,9 & 2048,8 & 1847,4 & 1592,7 & & \\
\hline & Direito & 2309,2 & 2185,7 & 2170,5 & 1904,4 & 1642,1 & & \\
\hline & Dif. (\%) & 8,23 & 9,83 & 5,60 & 2,99 & 3,01 & & \\
\hline \multirow{3}{*}{3} & Esquerdo & 2206,6 & 2071,6 & 2031,74 & 1843,6 & 1377,9 & & \\
\hline & Direito & 2387.1 & 2263.6 & 2141.98 & 1822,7 & 1214,5 & & \\
\hline & Dif. (\%) & 7,56 & 8,48 & 5,15 & 1,13 & 11,86 & & \\
\hline \multirow{3}{*}{ Média } & Esquerdo & 2164,9 & 2024,8 & 2045,7 & 1843.6 & 1604.1 & & \\
\hline & Direito & 2335,8 & 2215,5 & 2124,9 & 1832,8 & 1547,7 & & \\
\hline & Dif. (\%) & 7,32 & 8,61 & 3,73 & 0,58 & 3,52 & & \\
\hline \multicolumn{2}{|c|}{ Volume Total } & 4500,7 & 4240,3 & 4170,6 & 3676,4 & 3151,8 & & \\
\hline \multicolumn{2}{|c|}{ Tempo de Coleta } & 4,09 & 3,65 & 3,45 & 2,79 & 2,20 & & \\
\hline
\end{tabular}


O maior valor volumétrico entre os lados está representado nas Tabelas 21 a 26 pela cor azul Observando-se o nível zero de desgaste para todos os bicos, verifica-se que não houve alternância de lado de maior valor entre as três repetições. Para os demais niveis de desgaste, além de terem ocorrido poucas alternâncias, estas apresentaram pequenas diferenças porcentuais, o que permite afirmar que os perfis médios de distribuição construidos a partir do perfil individual das repetições são representativos, garantindo confiabilidade nas avaliações realizadas.

\subsubsection{Avaliação do ângulo do jato}

Os valores dos ângulos do jato foram determinados através de cálculo trigonométrico com base no largura da faixa de deposição e da altura do bico até a mesa de canaleta. Os resultados estão mostrados na Tabela 27 e representados graficamente na Figura 40

Todos os bicos apresentaram diminuições no ângulo, à medida que o nível de desgaste aumentou, com exceção do bico de kematal LD que sofreu pequenos aumentos até $20 \%$ de desgaste, terminando o teste, com ângulo semelhante ao inicial. O bico de cerâmica $\mathrm{ADI}$ mesmo com apenas $10 \%$ de desgaste, apresentou grande queda no ângulo do jato, na razão de 1 grau para cada $1 \%$ de nível de desgaste. $\mathrm{O}$ bico de aço inox DG também apresentou uma queda brusca no ângulo entre os níveis de 20 e $30 \%$. Esse comportamento de diminuição dos ângulos confirma a diminuição da faixa de deposição mostrada nos gráficos do perfil de distribuição nas Figuras 31 a 36, e está de acordo com os resultados obtidos por Balsari \& Tamagnone (1995), onde, citam que, para bicos de jato plano, o aumento da vazão reduziu o ângulo de pulverização e a largura do perfil de distribuição.

O bico de kematal LD, quando novo, apresentou o maior desvio do ângulo, em relação ao ângulo nominal $(-18,28 \%)$. Os demais bicos apresentaram desvios variando de $-3,46$ a $7,59 \%$. 
Tabela 27. Estimativas dos ângulos médios dos bicos de três repetições para cada nível de desgaste e coeficiente de variação, ângulo nominal e desvio médio dos bicos.

\begin{tabular}{|c|c|c|c|c|c|c|}
\hline Níveis de Desgaste & cer. XR & cer. ADI & kem UF & kem LD & Aço i. XR & aço i. DG \\
\hline 0 & 107,02 & 106,20 & 113,69 & 89,89 & 118,35 & 113,90 \\
\hline 5 & 105,79 & 100,16 & 116,03 & 92,28 & 116,55 & 110,16 \\
\hline 10 & 102,51 & 95,80 & 114,30 & 94,86 & 115,41 & 109,29 \\
\hline 20 & 98,27 & - & 115,75 & 96,02 & 115,06 & 106,12 \\
\hline 30 & 96,13 & - & 113,29 & 93,92 & 112,58 & 93,30 \\
\hline 40 & - & - & 109,82 & 93,20 & 109,06 & - \\
\hline 50 & - & - & 109,15 & 90,61 & 107,05 & - \\
\hline CV $(\%)^{(a)}$ & 0,70 & 1,85 & 0,00 & 0,00 & 0,44 & 1,52 \\
\hline$\widehat{A}_{\text {ngulo Nominal }}{ }^{(b)}$ & 110,00 & 110,00 & 110,00 & 110,00 & 110,00 & 110,00 \\
\hline Desvio Médio (\%) ${ }^{(c)}$ & $-2,71$ & $-3,46$ & 3,35 & $-18,28$ & 7,59 & 3,55 \\
\hline
\end{tabular}

(a) Coeficiente de variação das três repetições dos ângulos dos bicos novos

(b) Valor segundo catálogo do fabricante

(c) Desvio do ângulo do bico novo, em relação ao ângulo nominal, expresso em porcentagem deste

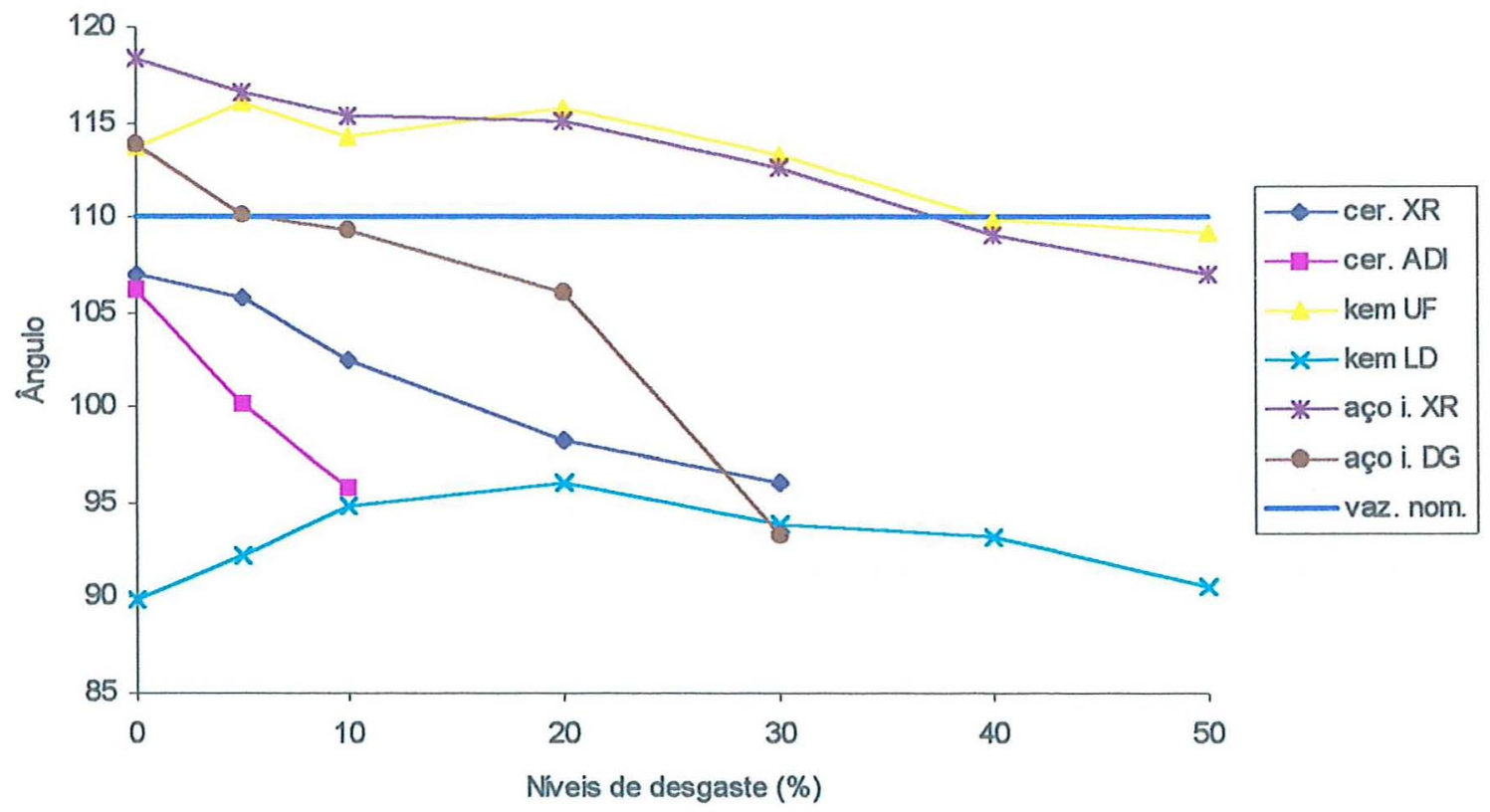

Figura 40. Gráfico do comportamento dos ângulos dos bicos nos diferentes níveis de desgaste 


\section{CONCLUSÕES}

As análises e discussões dos resultados obtidos possibilitaram as seguintes conclusões

- As análises realizadas indicaram que não houve um único produto abrasivo que fosse ideal para determinação do desgaste acelerado dos diversos tipos e materiais de confeç̧ão dos bicos estudados, havendo necessidade da subdivisão em, pelo menos, dois grupos: bicos de alta e baixa resistência ao desgaste.

- A variação dos aumentos porcentuais da vazão, entre exemplares, de um mesmo tipo de bico, foi maior na medida em que utilizou-se abrasivos de maior granulometria Sendo assim, o abrasivo Areia de Fundição, indicado pela norma NBR 13769, não garantiu confiabilidade dos resultados no teste realizado, para os bicos estudados.

- A ordem de resistência ao desgaste dos bicos estudados, quanto ao tipo e material de confecção, variou de acordo com o abrasivo utilizado.

- A resistência ao desgaste não foi apenas em função do material de confeç̧ão do bico, mas também, do tipo de atuação deste, ou seja, baixa deriva e uso ampliado.

- Bicos de baixa deriva apresentaram maior resistência ao desgaste em relação aos de uso ampliado, confeccionados do mesmo material. 
- Os resultados do perfil de distribuição, do ângulo do jato e das medidas dos diâmetros da elipse, mostraram que, o desgaste ocorreu no sentido do menor eixo da elipse, provocando diminuição da faixa de deposição, diminuição do ângulo do jato e conseqüente concentração de líquido no centro do perfil.

- Os estudos do comportamento do CV para cada canaleta nos diferentes niveis de desgaste e a avaliação da simetria volumétrica da distribuição garantiram confiabilidade no perfil de distribuição médio, e consequentemente nos $\mathrm{CV}$ médios.

- Na simulação em barra, alguns bicos desgastados apresentaram menor coeficiente de variação em relação ao mesmo quando novo, para a altura e o espaçamento estudados.

- Um aumento de até 10\% da vazão dos bicos confeccionados nos diferentes materiais, não provocou grande diferença no $\mathrm{CV}$ da uniformidade da distribuição, ficando este com valor abaixo de $12,22 \%$.

- Face aos resultados obtidos sugere-se que novas pesquisas sejam realizadas com relação ao efeito do desgaste na mudança do perfil de distribuição e também do tamanho de gota, para niveis de desgaste de até $50 \%$, a fim de se estabelecer quando estes parâmetros se tornam intoleráveis e quando os bicos devem ser substituídos. Além disso, um estudo sobre a relação entre o desgaste acelerado e o desgaste ocorrido na prática, seria de suma importância. 
REFERÊNCIAS BIBLIOGRÁFICAS

ASSOCIAÇÃO BRASILEIRA DE NORMAS TÉCNICAS. Bico de pulverização agrícola: métodos de ensaio - NBR 13769. Rio de Janeiro, 1997. 16p.

ASSOCIAÇÃO BRASILEIRA DE NORMAS TÉCNICAS. Pulverizador agrícola: terminologia - NBR 12936. Rio de Janeiro, 1993. 5p

ASSOCIATION FRANÇAISE DE NORMALISATION. PULVÉRISATEURS AGRICOLES. Méthodes d'essais fiche signalétique: NF U 26-110. Paris, 1979. $59 \mathrm{p}$.

ALBUZ CERAMIQUES. Bicos para culturas rasteiras. Evreux, 1991.10p.

AMERICAN SOCIETY FOR AGRICULTURAL ENGINEERS, ASAE standard 1995. St. Joseph, 1995, p.209-211: guide for preparing field sprayer calibration procedures. (ASAE, EP 367).

AMERICAN SOCIETY FOR AGRICULTURAL ENGINEERS. ASAE standard 1996. St. Joseph, 1996, p.297: Procedure for measuring sprayer nozzle wear rate (ASAE, S471 Dec. 95). 
AMERICAN SOCIETY FOR TESTING MATERIALS. Standard methods for testing agricultural hydraulic spray nozzles. Philadelphia, 1985. 5p. (ASTM, E 641- 85 Mar. 1991).

AZIMI, A.H; CARPENTER, T.G; REICHARD, D.L. Nozzle spray distribution for pesticide application. Transactions of the ASAE, v.28, n.5, p.1410-1414, Sept./Oct. 1985.

BALASTREIRE, L.A. Bicos pulverizadores: estudo da faixa de deposição. Piracicaba, 1970. 81p. Tese (Doutorado) - Escola Superior de Agricultura "Luiz de Queiroz", Universidade de São Paulo.

BALSARI, P.; TAMAGNONE, M. Characterization of functional parameters of the boom sprayers nozzles. First part: New nozzles. Rivista di Ingegneria Agraria, v.24, n.2, p.98-110, 1993. /Resumo 4184 em Agricultural Engineering Abstracts, v. 18 , n.11, p.445, Nov. 1993/.

BALSARI, P.; TAMAGNONE, M. Characterization of funtional parameters of boom sprayer nozzles. Second part: Life time of the nozzles. Rivista di Ingegneria Agraria, v.26, n.2, p.75-90, 1995, /Resumo em CAB Abstracts on CD-ROM, 1995/.

BARIK, M. ; KUHLMAN, D.K. Modeling of nozzle wear. St. Joseph: ASAE, 1990. 14p. (ASAE Paper, 90-901583).

BARNETT, G.S.; MATTHEWS, G.A. Effect of different fan nozzles and spray liquidson droplet spectra with special reference to drift control. International Pest Control, v.34, n.3, p.81-83, 1992. 
BARRUFET, J.M.; PLANAS, S.; FILLAT, A. Tratamientos por pulverización en cultivos bajos: Desgaste de boquillas y calidad de la aplicación. Phytoma, n.12, p. 13-17, Oct. 1989.

BENGTSSON, P. Pratical wear-tests of nozzles for field crop sprayers. In: SWEDISH CROP PROTECTION CONFERENCE, 36., Uppsala, 1995. Agriculture pests diseases. Uppsala: Swedish University of Agricultural Sciences, 1995. p.325-334. /Resumo em CAB Abstracts on CD-ROM, 1995/.

BODE, L.E; PEARSON, S. L.; ZEHR, D. L. Wear rate of flat Fan nozzle tips. In: ILLINOIS CUSTOM SPRAY OPERATORS TRAINING SCHOOL MANUAL, 36., Urbana, 1984. Summaries of presentations and pest control reference material. Urbana: University of Illinois, Cooperative Extension Service, 1984. p.132-134.

BOGLIANI,M.; ZOLOAGA,R.; PIANTANIDA,N. Analisis de la variacion del caudal por efect del desgaste. Buenos Aires: Instituto de Ingenieria Rural, 1994. 4p.

CHOE, K.J.; PARK, S.H.; KANG, C.H.; JUNG, I.K. Durability of nozzle discs for power Sprayer. RDA Journal of Agricultural Science, v.35, n.2, p.702-707, 1993. /Resumo 1677 em Agricultural Engineering Abstracts, v.19, n.5, p.180, May 1994/.

CHRISTOFOLETTI, J.C. Bicos e acessórios de barra na cultura de soja. 2.ed. São Paulo: Spraying Systems do Brasil, 1995. 27p.

CORRÊA, H.G. Ensaio do bico leque micron 110 C3 para pulverização agrícola Jundiai: Instituto Agronômico, Divisão de Engenharia Agrícola, 1987. 32p. 
CORRÊA, H.G. Ensaio do bico leque albuz-jacto APG 110R para pulverização agrícola. Jundiai: Instituto Agronômico, Divisão de Engenharia Agrícola, 1988. $37 \mathrm{p}$.

CORREAA, H.G.; LORENA NETO, B. Desgaste de bicos de pulverização pelo uso de formulações cúpricas. Bragantia, v.35, n.25, p.279-294, set. 1976.

DeBOER, L.J.; WIENS, E.H. Test procedures for granular applicator performance testing. St Joseph: ASAE, 1983. 15p. (ASAE Paper, 83-1504).

FRIESEN, O. H. Evaluation of wear rates of flat spray nozzles: Technical report Manitoba: Manitoba Agriculture, 1984.

FRIESEN, O. H. Nozzle wear, nozzle abuse and nozzle weathering tests. Manitoba: University of Manitoba, Technical Services and Training Branch, 1988. $6 \mathrm{p}$.

FURLANETTI, A.C. Vazão e deposição de bicos pulverizadores de jato em leque. Botucatu, 1995. 123p. Dissertação(Mestrado) - Faculdade de Ciências Agronômicas do Campus de Botucatu, Universidade Estadual Paulista Júlio de Mesquita Filho.

GALLI, J.C.; ARRUDA, A.C. Distribuição volumétrica dos bicos pulverizadores JD 14-2. Pesquisa Agropecuária Brasileira, v.20, n.11, p.1239-1244, nov. 1985.

GALLI, J.C.; MATUO, T.; SIQUEIRA, E.C. Padrão de distribuição de alguns bicos hidráulicos. Planta Daninha, v.6, n.2, p.144-150, 1983.

GANDOLFO, M.A. Efecto de la presion en el desgaste de boquillas de pulverizacion. La Plata, 1995. 49p. Dissertação (Mestrado) - Facultad de Ciencias Agrarias y Florestales, Universidad Nacional de La Plata. 
GOMES, F. P. A estatística moderna na pesquisa agropecuária. Piracicaba: Potafos, 1984. 160p.

HARDI INTERNATIONAL A/S. Nozzle catalogue. Taastrup, 1995. 27p.

INSTITUTO ESPAÑOL DE NORMALIZACIÓN. Maquinaria agrícola: equipos para tratamiento fitosanitario - boquillas de pulverización - métodos de ensayo- UNE 68-055-82. Madrid, 1982, 16p.

INTERNATIONAL ORGANIZATION FOR STANDARDIZATION. Equipament for crop protection: spraying equipment: Pt.1: test methods of sprayer nozzles- ISO 5682/1: 1981(E). Geneva, 1981. 14p.

INTERNATIONAL ORGANIZATION FOR STANDARDIZATION. Equipament for crop protection: agricultural sprayers- test methods-. ISO/DP 5682. Geneva, 1983. 66p.

INTERNATIONAL ORGANIZATION FOR STANDARDIZATION. Equipament for crop protection: spraying equipment - Pt. 2: test methods for agricultural sprayersISO 5682/2: 1986(E). Geneva, 1986. 5p.

INTERNATIONAL ORGANIZATION FOR STANDARDIZATION. Equipament for crop protection: spraying equipment: Pt.1: test methods of sprayer nozzles- ISO 5682/1: 1996(E), 2. ed. Geneva, 1997. 19p.

LEUNDA, P.; DEBOUCHE, C.; CAUSSIN, R. Predicting the transverse volume distribution under an agricultural spray boom. Crop Protection, v.9, n.2, p.111-114, Apr. 1990. 
MARQUEZ, L; PINZON, R. A; LAMAS, R. Influencia del desgaste de la boquilla de pulverización en la población de gotas resultante: Análise mediante rayo laser. Ingegneria Per lo Suiluppo dell' Agricoltor, v.2, n.10, p.887-892, 1988.

MATTHEWS, G.A. Pesticide apllication methods. 2.ed. London: Longman, 1992. $405 p$.

MATTHEWS, G.A.; THORNHILL, E.W. Equipo de aplicación de pesticida para uso en agricultura. Roma: FAO, 1996. v.1, 151p. (Boletin de Servicios Agricolas de la FAO, 112/1).

MAWER, C.J.; MILLER,P.C.H. Effect of rool angle and nozzle spray pattern on the uniformity of spray volume distribution below a boom. Crop Protection, v. 8 , n.3, p.217-223, June 1989.

MENZIES, D.R.; FISHER, W.R; NEFF, A.E. Wear of hollow cone nozzles by suspensions of wettable powders. Canadian Agricultural Engineering, v.18, n.1, p.14-15, 1976.

MICRON. Bicos cerâmicos: manual técnico de bolso. São Paulo: Pulsar Tecnologia Ind. e Com., s.d. $1 \mathrm{v}$.

NORDBO, E.; STEENSEN, J.K.; KIRKNEL, E. Deposition and efficiency of herbicide sprays in sugar beet with twin-fluid, low-drift and conventional hydraulic nozzles. Crop Protection, v. 14, n.3, p.237-240, May 1995.

NOVAK, M.J.; CAVALETTO R.A. Wear characteristics of flat fan nozzles. St Joseph: ASAE, 1988. 10 p. (ASAE Paper, 88-1015). 
ORGANIZACION MUNDIAL DE LA SALUD. Material de lucha contra los vectores. Ginebra, 1976. $189 \mathrm{p}$.

OZKAN, H.E; REICHARD, D.L.; ACKERMAN, K.D. Effect of nozzle wear on spray pattern. St Joseph: ASAE, 1991. 16p. (ASAE Paper, 91-1033).

OZKAN, H.E; REICHARD, D.L; ACKERMAN, K.D. Effect of orifice wear on spray patterns fron fan nozzles. Transactions of the ASAE, v.36, n.4, p.10911096, 1992a.

OZKAN, H.E.; REICHARD, D.L.; ACKERMAN, K.D.; SWEENEY, J.S. Droplet size distributions across the fan patterns of new and worn nozzles. Transactions of the ASAE, v.35, n.4, p.1097-1102, $1992 b$.

OZKAN, H.E.; REICHARD, D.L.; ACKERMAN, K.D.; SWEENEY, J.S.; BODE, L.E.; CHASIN, D.G. Effect of wear on spray characteristics of fan pattern nozzles made from different materials. Pesticide Formulations and Application Systems, v.11, p.206-217, 1992c. /Resumo em CAB Abstracts on CD-ROM, 1993-94/.

PALMIERI, A.C. Manual de hidráulica básica 6.ed. Porto Alegre: Racine Hidráulica, 1987. 326p.

PERECIN, D.; PERESSIN, V.A.; MATUO, T.; BARBOSA, J.C.; PIO, L.C; BRAZ, B.A. Padrões de distribuições obtidos com bicos TwinJet, em função da altura e do espaçamento entre bicos. Engenharia Agrícola, v. 14, p.19-30, 1994.

PIRARD, G.; LEUNDA, P.; DEBOUCHE, C.; CAUSSIN, R. [Contribution to the study of wear on spray nozzles]. Mededelingen van de Faculteit Landbouwwetenschappen Rijksuniversiteit Gent, v.54, n.2a, p.279-288, 1989. /Resumo em CAB Abstracts on CD-ROM, 1990-91/. 
REED,T; FERRAZZA, J. Wear life of agricultural nozzles. St Joseph: ASAE, 1984. 19p. (ASAE Paper, AA84-001).

REICHARD, D.L.; OZKAN,H.E.; FOX, R.D. Nozzle wear rates. St Joseph: ASAE, 1990. 20 p. (ASAE Paper, 90-1584).

REICHARD, D.L; OZKAN, H.E; FOX, R.D. Nozzle wear rates and test procedure. Transactions of the ASAE, v.34, n.6, p.2309-2316, 1991

RICE, B. The contribution of sprayer testing service to safer, more effective spraying. In: INTERNATIONAL SYMPOSIUM ON PESTICIDES APPLICATION TECHNIQUES, 2., Strasbourg, 1993. Paris:ANPP, 1993. v.2, p.505-512.

SARTORI, S. Condiderações a respeito da aplicação de defensivos por via líquida. Pompéia: Máquinas Agrícolas Jacto, 1975. 30p.

SARTORI, S. Pulverizadores para aplicação terrestre tratorizada. In: SIMPÓSIO BRASILEIRO SOBRE TECNOLOGIA DE APLICAÇÃO DE DEFENSIVOS AGRÍCOLAS: EFICIÊNCIA, ECONOMIA E PRESERVAÇÃO DA SAÚDE HUMANA E DO AMBIENTE, 1., Jaboticabal, 1985. Anais. Jaboticabal: FUNEP, 1987. p.47-79.

SAUNDERS, W. Completely moulded flat spray tips improve spraying application. Proceedings North Central Weed Control Conference, v.36, p.5-6, 1981. /Resumo em CAB Abstracts on CD-ROM, 1982-83/.

SINTORN, K. Wear of hidraulic nozzles in field sprayers. In: SWEDISH WEED CONFERENCE, 23., Uppsala, 1982. Weeds and weed control: proceedings. Uppsala: Sveriges Lantbruksuniversitet, 1982. v.1, p.143-154. /Resumo em CAB Abstracts on CD-ROM, 1982-83/. 
SPRAYING SYSTEMS CO. TeeJet: Produtos de pulverização para agricultura. Wheaton, 1994. 80 p. (Cat. 44M-P).

TEEJET JOURNAL. The up's and down's of sprayer distribuition. Wheaton, v.2, n.1, 1990 .

THORNHILL, E.W. ; MATTHEWS, G.A. Equipo de aplicación de pesticida para uso en agricultura. Roma: FAO, 1996 v.2: equipo impulsado mecánicamente, 150p. (Boletin de Servicios Agricolas de la FAO, 112/2).

TREFÁN, L. Field assesment of spray patterns on tractor sprayers. Crop Protection, v.3, p.507-512, 1984.

WANG, L.; ZHANG, N.; SLOCOMBE, J.W.; THIERSTEIN, G.E.; KUHLMAN, D.K. Experimental analysis of spray distribution pattern uniformity for agricultural nozzles. Applied Engineering in Agriculture, v.11, n.1, p.51-55, Jan. 1995.

WOLF, D.D.; SMITH, E.S. Uniformity of seed and fertilizer distribution with a handoperated spinning spreader. Transactions of the ASAE, v.22, n.4, p.761-762, 1979.

ZHU,H; REICHARD, D.L; OZKAN, H.E; BRAZEE, R.D; FOX, R.D. A Mathematical model to predict the wear rate of nozzles with elliptical orifices. Transactions of the ASAE, v.37, n.5, p1297-1303, 1995. 


\section{APÊNDICE}


APÊNDICE 1 Dados originais do aumento da vazão (litro/min) em função do tempo de desgaste (Hora), para as três repetições nos diferentes bicos, utilizando o abrasivo Coríndon grão 800 .

\begin{tabular}{|c|c|c|c|c|c|c|}
\hline Hora & cer. XR & cer ADI & kem UF & kem LD & aço i. XR & aço i. DG \\
\hline 0 & 1,14 & 1,18 & 1,16 & 1,18 & 1,14 & 1,12 \\
\hline 0 & 1,14 & 1,18 & 1,16 & 1,18 & 1,14 & 1,12 \\
\hline 0 & 1,14 & 1,18 & 1,16 & 1,18 & 1,14 & 1,12 \\
\hline 1 & 1,14 & 1,18 & 1,08 & 1,11 & 1,28 & 1,15 \\
\hline 1 & 1,14 & 1,18 & 1,08 & 1,15 & 1,27 & 1,15 \\
\hline 1 & 1,14 & 1,18 & 1,08 & 1,14 & 1,27 & 1,14 \\
\hline 2 & 1,14 & 1,19 & 1,06 & 1,12 & 1,31 & 1,17 \\
\hline 2 & 1,15 & 1,19 & 1,08 & 1,15 & 1,31 & 1,17 \\
\hline 2 & 1,15 & 1,19 & 1,07 & 1,15 & 1,32 & 1,17 \\
\hline 4 & 1,15 & 1,19 & 1,06 & 1,14 & 1,38 & 1,18 \\
\hline 4 & 1,15 & 1,20 & 1,07 & 1,18 & 1,37 & 1,17 \\
\hline 4 & 1,15 & 1,19 & 1,07 & 1,16 & 1,36 & 1,18 \\
\hline 6,5 & 1,14 & 1,19 & 1,08 & 1,16 & 1,41 & 1,19 \\
\hline 6,5 & 1,14 & 1,19 & 1,09 & 1,20 & 1,42 & 1,17 \\
\hline 6,5 & 1,14 & 1,18 & 1,08 & 1,19 & 1,41 & 1,18 \\
\hline 10 & 1,15 & 1,19 & 1,09 & 1,18 & 1,48 & 1,19 \\
\hline 10 & 1,16 & 1,19 & 1,09 & 1,21 & 1,49 & 1,18 \\
\hline 10 & 1,15 & 1,19 & 1,09 & 1,19 & 1,49 & 1,18 \\
\hline 15 & 1,15 & 1,20 & 1,12 & 1,20 & 1,56 & 1,20 \\
\hline 15 & 1,16 & 1,20 & 1,12 & 1,23 & 1,56 & 1,20 \\
\hline 15 & 1,15 & 1,20 & 1,12 & 1,21 & 1,56 & 1,20 \\
\hline 20 & 1,15 & 1,20 & 1,14 & 1,22 & 1,62 & 1,21 \\
\hline 20 & 1,16 & 1,20 & 1,14 & 1,27 & 1,62 & 1,20 \\
\hline 20 & 1,16 & 1,19 & 1,14 & 1,24 & 1,62 & 1,22 \\
\hline 25 & 1,15 & 1,20 & 1,16 & 1,25 & 1,69 & 1,22 \\
\hline 25 & 1,15 & 1,20 & 1,16 & 1,29 & 1,68 & 1,22 \\
\hline 25 & 1,15 & 1,19 & 1,15 & 1,26 & 1,69 & 1,22 \\
\hline 30 & 1,16 & 1,20 & 1,17 & 1,28 & 1,73 & 1,22 \\
\hline 30 & 1,16 & 1,20 & 1,18 & 1,29 & 1,74 & 1,22 \\
\hline 30 & 1,15 & 1,19 & 1,16 & 1,27 & 1,73 & 1,23 \\
\hline 40 & 1,16 & 1,21 & 1,21 & 1,30 & 1,87 & 1,24 \\
\hline 40 & 1,16 & 1,21 & 1,22 & 1,33 & 1,87 & 1,24 \\
\hline 40 & 1,16 & 1,20 & 1,20 & 1,31 & 1,87 & 1,25 \\
\hline 50 & 1,16 & 1,21 & 1,26 & 1,34 & 2,02 & 1,26 \\
\hline 50 & 1,16 & 1,21 & 1,27 & 1,37 & 2,02 & 1,26 \\
\hline 50 & 1,16 & 1,21 & 1,26 & 1,35 & 2,02 & 1,26 \\
\hline
\end{tabular}


APÊNDICE 2 Dados originais do aumento da vazão (litro/min) em função do tempo de desgaste (Hora), para as três repetições nos diferentes bicos, utilizando o abrasivo Carbeto de Silício - SIC 800.

\begin{tabular}{ccccccc}
\hline Hora & cer. XR & cer ADI & kem UF & kem LD & aço i. XR & aço i. DG \\
\hline 0 & 1,14 & 1,19 & 1,15 & 1,20 & 1,15 & 1,12 \\
0 & 1,14 & 1,19 & 1,14 & 1,20 & 1,15 & 1,12 \\
0 & 1,14 & 1,19 & 1,14 & 1,20 & 1,15 & 1,12 \\
1 & 1,16 & 1,20 & 1,08 & 1,18 & 1,32 & 1,15 \\
1 & 1,15 & 1,20 & 1,06 & 1,19 & 1,32 & 1,16 \\
1 & 1,15 & 1,20 & 1,08 & 1,18 & 1,32 & 1,15 \\
2 & 1,16 & 1,21 & 1,09 & 1,21 & 1,38 & 1,15 \\
2 & 1,16 & 1,21 & 1,08 & 1,21 & 1,38 & 1,17 \\
2 & 1,16 & 1,20 & 1,09 & 1,21 & 1,38 & 1,16 \\
4 & 1,18 & 1,21 & 1,12 & 1,23 & 1,47 & 1,17 \\
4 & 1,16 & 1,20 & 1,10 & 1,25 & 1,46 & 1,18 \\
4 & 1,17 & 1,20 & 1,11 & 1,26 & 1,46 & 1,17 \\
6,5 & 1,18 & 1,21 & 1,15 & 1,26 & 1,56 & 1,18 \\
6,5 & 1,18 & 1,20 & 1,13 & 1,27 & 1,55 & 1,20 \\
6,5 & 1,18 & 1,20 & 1,14 & 1,27 & 1,56 & 1,18 \\
10 & 1,19 & 1,21 & 1,18 & 1,30 & 1,67 & 1,20 \\
10 & 1,18 & 1,20 & 1,18 & 1,31 & 1,66 & 1,23 \\
10 & 1,19 & 1,20 & 1,18 & 1,31 & 1,68 & 1,20 \\
15 & 1,20 & 1,22 & 1,25 & 1,34 & 1,82 & 1,22 \\
15 & 1,19 & 1,21 & 1,24 & 1,34 & 1,84 & 1,25 \\
15 & 1,20 & 1,20 & 1,25 & 1,35 & 1,84 & 1,22 \\
20 & 1,21 & 1,22 & 1,30 & 1,38 & 1,96 & 1,24 \\
20 & 1,20 & 1,22 & 1,29 & 1,39 & 1,96 & 1,27 \\
20 & 1,20 & 1,21 & 1,30 & 1,40 & 1,98 & 1,24 \\
25 & 1,21 & 1,22 & 1,34 & 1,41 & 2,12 & 1,25 \\
25 & 1,21 & 1,22 & 1,33 & 1,42 & 2,12 & 1,28 \\
25 & 1,20 & 1,21 & 1,34 & 1,42 & 2,14 & 1,24 \\
30 & 1,21 & 1,22 & 1,43 & 1,46 & 2,31 & 1,26 \\
30 & 1,21 & 1,22 & 1,41 & 1,47 & 2,32 & 1,30 \\
30 & 1,21 & 1,21 & 1,42 & 1,47 & 2,34 & 1,26 \\
40 & 1,22 & 1,22 & 1,52 & 1,50 & 2,70 & 1,30 \\
40 & 1,22 & 1,22 & 1,49 & 1,50 & 2,66 & 1,31 \\
40 & 1,22 & 1,21 & 1,51 & 1,47 & 2,73 & 1,28 \\
50 & 1,22 & 1,22 & 1,61 & 1,55 & 2,54 & 1,31 \\
50 & 1,22 & 1,22 & 1,58 & 1,54 & 2,54 & 1,32 \\
50 & 1,23 & 1,21 & 1,60 & 1,50 & 2,54 & 1,29 \\
\hline & & & & & & \\
& 1,25 &
\end{tabular}


APÊNDICE 3 Dados originais do aumento da vazão (litro/min) em função do tempo de desgaste (Hora), para as três repetições nos diferentes bicos, utilizando o abrasivo Caulim O.B. 2150.

\begin{tabular}{|c|c|c|c|c|c|c|}
\hline Hora & cer. XR & cer ADI & kem UF & kem LD & aço i. XR & aço i. DG \\
\hline 0 & 1,14 & 1,18 & 1,16 & 1,18 & 1,14 & 1,12 \\
\hline 0 & 1,14 & 1,18 & 1,16 & 1,19 & 1,14 & 1,12 \\
\hline 0 & 1,14 & 1,18 & 1,16 & 1,18 & 1,15 & 1,12 \\
\hline 1 & 1,15 & 1,18 & 1,14 & 1,17 & 1,18 & 1,13 \\
\hline 1 & 1,15 & 1,19 & 1,13 & 1,17 & 1,18 & 1,12 \\
\hline 1 & 1,15 & 1,19 & 1,13 & 1,18 & 1,18 & 1,13 \\
\hline 2 & 1,15 & 1,18 & 1,12 & 1,16 & 1,18 & 1,12 \\
\hline 2 & 1,15 & 1,19 & 1,11 & 1,16 & 1,18 & 1,12 \\
\hline 2 & 1,15 & 1,19 & 1,11 & 1,19 & 1,18 & 1,14 \\
\hline 4 & 1,15 & 1,18 & 1,11 & 1,18 & 1,20 & 1,13 \\
\hline 4 & 1,15 & 1,19 & 1,10 & 1,17 & 1,20 & 1,12 \\
\hline 4 & 1,15 & 1,19 & 1,10 & 1,19 & 1,20 & 1,13 \\
\hline 6,5 & 1,16 & 1,18 & 1,11 & 1,19 & 1,21 & 1,13 \\
\hline 6,5 & 1,15 & 1,19 & 1,10 & 1,17 & 1,21 & 1,13 \\
\hline 6,5 & 1,15 & 1,19 & 1,11 & 1,20 & 1,21 & 1,13 \\
\hline 10 & 1,16 & 1,19 & 1,12 & 1,19 & 1,23 & 1,14 \\
\hline 10 & 1,16 & 1,19 & 1,12 & 1,18 & 1,23 & 1,13 \\
\hline 10 & 1,15 & 1,19 & 1,12 & 1,20 & 1,23 & 1,14 \\
\hline 15 & 1,16 & 1,19 & 1,14 & 1,20 & 1,25 & 1,14 \\
\hline 15 & 1,16 & 1,19 & 1,14 & 1,20 & 1,24 & 1,14 \\
\hline 15 & 1,15 & 1,19 & 1,15 & 1,22 & 1,25 & 1,14 \\
\hline 20 & 1,16 & 1,19 & 1,17 & 1,22 & 1,26 & 1,16 \\
\hline 20 & 1,16 & 1,19 & 1,17 & 1,22 & 1,26 & 1,15 \\
\hline 20 & 1,16 & 1,19 & 1,18 & 1,24 & 1,26 & 1,16 \\
\hline 25 & 1,16 & 1,19 & 1,19 & 1,23 & 1,27 & 1,16 \\
\hline 25 & 1,16 & 1,19 & 1,18 & 1,23 & 1,27 & 1,15 \\
\hline 25 & 1,16 & 1,19 & 1,19 & 1,26 & 1,27 & 1,16 \\
\hline 30 & 1,16 & 1,19 & 1,21 & 1,25 & 1,28 & 1,16 \\
\hline 30 & 1,16 & 1,19 & 1,21 & 1,25 & 1,28 & 1,16 \\
\hline 30 & 1,16 & 1,19 & 1,21 & 1,25 & 1,28 & 1,17 \\
\hline 40 & 1,16 & 1,19 & 1,25 & 1,27 & 1,30 & 1,17 \\
\hline 40 & 1,16 & 1,19 & 1,25 & 1,28 & 1,30 & 1,16 \\
\hline 40 & 1,16 & 1,20 & 1,27 & 1,28 & 1,30 & 1,18 \\
\hline 50 & 1,17 & 1,19 & 1,30 & 1,28 & 1,32 & 1,18 \\
\hline 50 & 1,17 & 1,20 & 1,30 & 1,28 & 1,32 & 1,18 \\
\hline 50 & 1,17 & 1,20 & 1,31 & 1,31 & 1,32 & 1,20 \\
\hline
\end{tabular}


APÊNDICE 4 Dados originais do aumento da vazão (litro/min) em função do tempo de desgaste (Hora), para as três repetições nos diferentes bicos, utilizando o abrasivo Alumina Calcinada APC - 2011 SG.

\begin{tabular}{|c|c|c|c|c|c|c|}
\hline Hora & cer. XR & cer ADI & kem UF & kem LD & aço i. XR & aço i. DG \\
\hline 0 & 1,15 & 1,22 & 1,15 & 1,21 & 1,16 & 1,12 \\
\hline 0 & 1,15 & 1,22 & 1,15 & 1,21 & 1,16 & 1,12 \\
\hline 0 & 1,15 & 1,22 & 1,14 & 1,20 & 1,17 & 1,12 \\
\hline 1 & 1,15 & 1,22 & 1,14 & 1,20 & 1,21 & 1,16 \\
\hline 1 & 1,15 & 1,22 & 1,13 & 1,21 & 1,21 & 1,13 \\
\hline 1 & 1,15 & 1,22 & 1,13 & 1,18 & 1,21 & 1,14 \\
\hline 2 & 1,15 & 1,22 & 1,13 & 1,19 & 1,22 & 1,16 \\
\hline 2 & 1,15 & 1,22 & 1,13 & 1,20 & 1,21 & 1,13 \\
\hline 2 & 1,15 & 1,22 & 1,12 & 1,17 & 1,22 & 1,14 \\
\hline 4 & 1,15 & 1,22 & 1,13 & 1,19 & 1,23 & 1,16 \\
\hline 4 & 1,15 & 1,22 & 1,13 & 1,19 & 1,22 & 1,13 \\
\hline 4 & 1,15 & 1,22 & 1,12 & 1,17 & 1,22 & 1,14 \\
\hline 6,5 & 1,15 & 1,22 & 1,13 & 1,19 & 1,24 & 1,16 \\
\hline 6,5 & 1,15 & 1,22 & 1,13 & 1,19 & 1,23 & 1,14 \\
\hline 6,5 & 1,15 & 1,22 & 1,12 & 1,17 & 1,23 & 1,14 \\
\hline 10 & 1,15 & 1,22 & 1,11 & 1,18 & 1,24 & 1,16 \\
\hline 10 & 1,15 & 1,22 & 1,11 & 1,19 & 1,23 & 1,14 \\
\hline 10 & 1,15 & 1,22 & 1,10 & 1,17 & 1,24 & 1,14 \\
\hline 15 & 1,15 & 1,22 & 1,11 & 1,19 & 1,26 & 1,16 \\
\hline 15 & 1,15 & 1,22 & 1,10 & 1,19 & 1,24 & 1,15 \\
\hline 15 & 1,16 & 1,23 & 1,10 & 1,18 & 1,25 & 1,15 \\
\hline 20 & 1,15 & 1,22 & 1,10 & 1,20 & 1,26 & 1,16 \\
\hline 20 & 1,15 & 1,22 & 1,10 & 1,19 & 1,24 & 1,15 \\
\hline 20 & 1,16 & 1,23 & 1,10 & 1,18 & 1,26 & 1,15 \\
\hline 25 & 1,15 & 1,22 & 1,10 & 1,20 & 1,26 & 1,16 \\
\hline 25 & 1,15 & 1,22 & 1,10 & 1,19 & 1,24 & 1,15 \\
\hline 25 & 1,16 & 1,23 & 1,10 & 1,18 & 1,26 & 1,16 \\
\hline 30 & 1,15 & 1,22 & 1,10 & 1,20 & 1,27 & 1,17 \\
\hline 30 & 1,16 & 1,22 & 1,10 & 1,20 & 1,25 & 1,15 \\
\hline 30 & 1,16 & 1,23 & 1,10 & 1,18 & 1,27 & 1,16 \\
\hline 40 & 1,15 & 1,22 & 1,10 & 1,20 & 1,27 & 1,17 \\
\hline 40 & 1,16 & 1,22 & 1,09 & 1,20 & 1,26 & 1,16 \\
\hline 40 & 1,16 & 1,23 & 1,09 & 1,18 & 1,27 & 1,16 \\
\hline 50 & 1,15 & 1,22 & 1,09 & 1,20 & 1,27 & 1,17 \\
\hline 50 & 1,16 & 1,22 & 1,09 & 1,20 & 1,26 & 1,16 \\
\hline 50 & 1,16 & 1,23 & 1,09 & 1,18 & 1,28 & 1,16 \\
\hline
\end{tabular}


APÊNDICE 5 Dados originais do aumento da vazão (litro/min) em função do tempo de desgaste (Hora), para as três repetições nos diferentes bicos, utilizando o abrasivo Carbeto de Silício - SIC 240.

\begin{tabular}{ccccccc}
\hline Hora & cer. XR & cer ADI & kem UF & kem LD & aço i. XR & aço i. DG \\
\hline 0 & 1,14 & 1,20 & 1,14 & 1,18 & 1,14 & 1,12 \\
0 & 1,14 & 1,20 & 1,14 & 1,18 & 1,14 & 1,11 \\
0 & 1,14 & 1,31 & 1,14 & 1,18 & 1,14 & 1,12 \\
0,5 & 1,25 & 1,25 & 1,26 & 1,32 & 1,52 & 1,20 \\
0,5 & 1,24 & 1,26 & 1,26 & 1,32 & 1,45 & 1,19 \\
0,5 & 1,25 & 1,32 & 1,16 & 1,32 & 1,52 & 1,20 \\
1 & 1,30 & 1,28 & 1,44 & 1,45 & 1,70 & 1,24 \\
1 & 1,28 & 1,30 & 1,44 & 1,48 & 1,61 & 1,24 \\
1 & 1,29 & 1,33 & 1,34 & 1,58 & 1,70 & 1,24 \\
2 & 1,35 & 1,28 & 1,94 & 1,69 & 2,04 & 1,28 \\
2 & 1,33 & 1,32 & 1,84 & 1,72 & 1,98 & 1,28 \\
2 & 1,34 & 1,40 & 1,75 & 1,84 & 1,96 & 1,30 \\
3 & 1,39 & 1,28 & 2,58 & 1,88 & 2,52 & 1,30 \\
3 & 1,37 & 1,32 & 2,52 & 1,86 & 2,38 & 1,30 \\
3 & 1,38 & 1,40 & 2,31 & 2,04 & 2,34 & 1,32 \\
4 & 1,42 & 1,28 & & & & 1,31 \\
4 & 1,40 & 1,32 & & & & 1,32 \\
4 & 1,41 & 1,44 & & & & 1,35 \\
6 & 1,48 & 1,29 & & & & 1,36 \\
6 & 1,45 & 1,35 & & & & 1,36 \\
6 & 1,46 & 1,45 & & & & 1,39 \\
10 & 1,56 & 1,29 & & & & 1,36 \\
10 & 1,53 & 1,37 & & & & 1,37 \\
10 & 1,53 & 1,47 & & & & 1,40 \\
15 & 1,65 & 1,30 & & & & 1,40 \\
15 & 1,62 & 1,38 & & & & 1,40 \\
15 & 1,63 & 1,66 & & & & 1,43 \\
20 & 1,70 & 1,30 & & & & 1,46 \\
20 & 1,68 & 1,41 & & & & \\
20 & 1,72 & 1,67 & & & & \\
30 & 1,86 & 1,32 & & & & \\
30 & 1,80 & 1,44 & & & & \\
30 & 1,88 & 1,77 & & & & \\
\hline
\end{tabular}


APÊNDICE 6 Dados originais do aumento da vazão (litro/min) em função do tempo de desgaste (Hora), para as três repetições nos diferentes bicos, utilizando o abrasivo Carbeto de Silício - SIC 500.

\begin{tabular}{|c|c|c|c|c|c|c|}
\hline Hora & cer XR & cer ADI & kem UF & kem LD & aço i. XR & aço i. DG \\
\hline 0 & 1,14 & 1,17 & 1,13 & 1,16 & 1,14 & 1,10 \\
\hline 0 & 1,14 & 1,18 & 1,13 & 1,17 & 1,14 & 1,10 \\
\hline 0 & 1,14 & 1,17 & 1,13 & 1,17 & 1,14 & 1,10 \\
\hline 0,5 & 1,16 & 1,17 & 1,04 & 1,12 & 1,32 & 1,14 \\
\hline 0,5 & 1,15 & 1,18 & 1,04 & 1,13 & 1,32 & 1,14 \\
\hline 0,5 & 1,16 & 1,17 & 1,03 & 1,12 & 1,32 & 1,14 \\
\hline 1 & 1,16 & 1,17 & 1,05 & 1,14 & 1,40 & 1,16 \\
\hline 1 & 1,16 & 1,19 & 1,05 & 1,16 & 1,40 & 1,16 \\
\hline 1 & 1,16 & 1,18 & 1,04 & 1,14 & 1,40 & 1,16 \\
\hline 2 & 1,18 & 1,17 & 1,07 & 1,18 & 1,51 & 1,18 \\
\hline 2 & 1,18 & 1,19 & 1,08 & 1,18 & 1,50 & 1,17 \\
\hline 2 & 1,18 & 1,18 & 1,06 & 1,18 & 1,49 & 1,17 \\
\hline 4 & 1,20 & 1,18 & 1,15 & 1,28 & 1,68 & 1,19 \\
\hline 4 & 1,20 & 1,19 & 1,16 & 1,28 & 1,68 & 1,20 \\
\hline 4 & 1,20 & 1,19 & 1,14 & 1,28 & 1,68 & 1,18 \\
\hline 6,5 & 1,22 & 1,19 & 1,21 & 1,34 & 1,86 & 1,22 \\
\hline 6,5 & 1,22 & 1,19 & 1,22 & 1,34 & 1,85 & 1,23 \\
\hline 6,5 & 1,22 & 1,20 & 1,21 & 1,33 & 1,84 & 1,22 \\
\hline 10 & 1,23 & 1,19 & 1,25 & 1,34 & 1,97 & 1,23 \\
\hline 10 & 1,23 & 1,20 & 1,26 & 1,38 & 1,98 & 1,24 \\
\hline 10 & 1,23 & 1,20 & 1,25 & 1,35 & 1,95 & 1,22 \\
\hline 15 & 1,24 & 1,20 & 1,38 & 1,42 & 2,34 & 1,26 \\
\hline 15 & 1,24 & 1,20 & 1,38 & 1,48 & 2,34 & 1,28 \\
\hline 15 & 1,24 & 1,21 & 1,36 & 1,44 & 2,28 & 1,24 \\
\hline 20 & 1,26 & 1,20 & 1,50 & 1,46 & 2,76 & 1,28 \\
\hline 20 & 1,25 & 1,21 & 1,48 & 1,56 & 2,55 & 1,29 \\
\hline 20 & 1,26 & 1,21 & 1,48 & 1,52 & 2,64 & 1,25 \\
\hline 25 & 1,27 & 1,20 & 1,58 & 1,52 & & 1,30 \\
\hline 25 & 1,26 & 1,21 & 1,57 & 1,60 & & 1,31 \\
\hline 25 & 1,27 & 1,21 & 1,58 & 1,58 & & 1,29 \\
\hline 35 & 1,28 & 1,20 & 1,83 & 1,60 & & 1,33 \\
\hline 35 & 1,28 & 1,21 & 1,82 & 1,66 & & 1,34 \\
\hline 35 & 1,28 & 1,21 & 1,85 & 1,67 & & 1,3 \\
\hline 50 & 1,30 & 1,21 & & 1,78 & & 1,34 \\
\hline 50 & 1,30 & 1,21 & & 1,86 & & 1,33 \\
\hline 50 & 1,30 & 1,22 & & 1,86 & & 1,34 \\
\hline
\end{tabular}


APÊNDICE 7 Dados originais do aumento da vazão (litro/min) em função do tempo de desgaste (Hora), para as três repetições nos diferentes bicos, utilizando o abrasivo Oxido de Alumínio Branco (FFF).

\begin{tabular}{|c|c|c|c|c|c|c|}
\hline Hora & cer. XR & cer ADI & kem UF & kem LD & aço i. XR & aço i. DG \\
\hline 0 & 1,14 & 1,20 & 1,13 & 1,18 & 1,17 & 1,10 \\
\hline 0 & 1,14 & 1,20 & 1,13 & 1,18 & 1,17 & 1,10 \\
\hline 0 & 1,14 & 1,21 & 1,13 & 1,18 & 1,17 & 1,10 \\
\hline 0,5 & 1,20 & 1,18 & 1,21 & 1,30 & 1,49 & 1,17 \\
\hline 0,5 & 1,19 & 1,19 & 1,21 & 1,31 & 1,49 & 1,15 \\
\hline 0,5 & 1,18 & 1,21 & 1,18 & 1,31 & 1,47 & 1,18 \\
\hline 1 & 1,21 & 1,19 & 1,30 & 1,42 & 1,62 & 1,21 \\
\hline 1 & 1,20 & 1,19 & 1,32 & 1,46 & 1,62 & 1,18 \\
\hline 1 & 1,19 & 1,22 & 1,30 & 1,44 & 1,65 & 1,21 \\
\hline 2 & 1,23 & 1,19 & 1,43 & 1,56 & 1,93 & 1,23 \\
\hline 2 & 1,21 & 1,20 & 1,58 & 1,64 & 1,90 & 1,20 \\
\hline 2 & 1,22 & 1,22 & 1,49 & 1,62 & 1,93 & 1,23 \\
\hline 4 & 1,26 & 1,21 & & 1,82 & & 1,27 \\
\hline 4 & 1,25 & 1,21 & & 1,88 & & 1,25 \\
\hline 4 & 1,24 & 1,23 & & 1,82 & & 1,23 \\
\hline 6,5 & 1,29 & 1,21 & & & & 1,29 \\
\hline 6,5 & 1,28 & 1,21 & & & & 1,29 \\
\hline 6,5 & 1,26 & 1,24 & & & & 1,29 \\
\hline 10 & 1,31 & 1,22 & & & & 1,33 \\
\hline 10 & 1,31 & 1,23 & & & & 1,32 \\
\hline 10 & 1,28 & 1,24 & & & & 1,31 \\
\hline 15 & 1,34 & 1,23 & & & & 1,34 \\
\hline 15 & 1,33 & 1,24 & & & & 1,34 \\
\hline 15 & 1,33 & 1,25 & & & & 1,34 \\
\hline 20 & 1,38 & 1,24 & & & & 1,36 \\
\hline 20 & 1,36 & 1,24 & & & & 1,36 \\
\hline 20 & 1,34 & 1,25 & & & & 1,36 \\
\hline 30 & 1,44 & 1,25 & & & & 1,40 \\
\hline 30 & 1,42 & 1,26 & & & & 1,40 \\
\hline 30 & 1,40 & 1,26 & & & & 1,38 \\
\hline 40 & 1,50 & 1,26 & & & & 1,40 \\
\hline 40 & 1,48 & 1,26 & & & & 1,42 \\
\hline 40 & 1,43 & 1,26 & & & & 1,41 \\
\hline 50 & 1,53 & 1,26 & & & & 1,41 \\
\hline 50 & 1,53 & 1,27 & & & & 1,44 \\
\hline 50 & 1,47 & 1,26 & & & & 1,44 \\
\hline
\end{tabular}


APÊNDICE 8 Dados originais do aumento da vazão (litro/min) em função do tempo de desgaste (Hora), para as três repetições nos diferentes bicos, utilizando o abrasivo Bióxido de Silício - Tixosil 73

\begin{tabular}{ccccccc}
\hline Hora & cer. XR & cer ADI & kem UF & kem LD & aço i. XR & aço i. DG \\
\hline 0 & 1,14 & 1,17 & 1,13 & 1,18 & 1,15 & 1,13 \\
0 & 1,14 & 1,17 & 1,13 & 1,18 & 1,15 & 1,13 \\
0 & 1,14 & 1,17 & 1,13 & 1,18 & 1,15 & 1,13 \\
1 & 1,17 & 1,17 & 1,18 & 1,25 & 1,30 & 1,15 \\
1 & 1,17 & 1,17 & 1,18 & 1,25 & 1,29 & 1,15 \\
1 & 1,17 & 1,18 & 1,19 & 1,26 & 1,29 & 1,17 \\
2 & 1,19 & 1,18 & 1,27 & 1,33 & 1,35 & 1,19 \\
2 & 1,19 & 1,18 & 1,27 & 1,32 & 1,34 & 1,18 \\
2 & 1,18 & 1,18 & 1,28 & 1,32 & 1,34 & 1,20 \\
4 & 1,21 & 1,19 & 1,44 & 1,41 & 1,40 & 1,21 \\
4 & 1,21 & 1,18 & 1,43 & 1,39 & 1,40 & 1,20 \\
4 & 1,21 & 1,18 & 1,44 & 1,40 & 1,40 & 1,22 \\
6,5 & 1,22 & 1,19 & 1,60 & 1,48 & 1,44 & 1,21 \\
6,5 & 1,23 & 1,19 & 1,60 & 1,46 & 1,44 & 1,22 \\
6,5 & 1,22 & 1,19 & 1,61 & 1,46 & 1,43 & 1,24 \\
10 & 1,23 & 1,19 & 1,82 & 1,58 & 1,50 & 1,25 \\
10 & 1,24 & 1,19 & 1,82 & 1,54 & 1,49 & 1,24 \\
10 & 1,24 & 1,20 & 1,81 & 1,56 & 1,48 & 1,26 \\
15 & 1,26 & 1,19 & 2,08 & 1,65 & 1,54 & 1,27 \\
15 & 1,26 & 1,20 & 2,08 & 1,64 & 1,54 & 1,26 \\
15 & 1,26 & 1,20 & 2,10 & 1,66 & 1,53 & 1,28 \\
20 & 1,27 & 1,20 & 2,31 & 1,74 & 1,58 & 1,28 \\
20 & 1,27 & 1,20 & 2,34 & 1,73 & 1,58 & 1,28 \\
20 & 1,27 & 1,20 & 2,34 & 1,75 & 1,57 & 1,30 \\
30 & 1,29 & 1,21 & & 1,90 & 1,64 & 1,32 \\
30 & 1,29 & 1,20 & & 1,86 & 1,64 & 1,32 \\
30 & 1,29 & 1,20 & & 1,88 & 1,64 & 1,32 \\
40 & 1,31 & 1,21 & & 2,00 & 1,70 & 1,34 \\
40 & 1,32 & 1,21 & & 2,00 & 1,70 & 1,34 \\
40 & 1,31 & 1,21 & & 2,02 & 1,70 & 1,34 \\
50 & 1,32 & 1,21 & & 2,12 & 1,73 & 1,35 \\
50 & 1,32 & 1,21 & & 2,12 & 1,73 & 1,35 \\
50 & 1,32 & 1,22 & & 2,13 & 1,72 & 1,35 \\
\hline & & & & & &
\end{tabular}


APÊNDICE 9 Dados originais do aumento da vazão (litro/min) em função do tempo de desgaste (Hora), para as três repetições nos diferentes bicos, utilizando o abrasivo Areia de Fundição para Shellmold.

\begin{tabular}{|c|c|c|c|c|c|c|}
\hline Hora & cer. XR & cer ADI & kem UF & kem LD & aço i. XR & aço i. DG \\
\hline 0 & 1,18 & 1,19 & 1,15 & 1,20 & 1,17 & 1,12 \\
\hline 0 & 1,18 & 1,19 & 1,15 & 1,20 & 1,17 & 1,12 \\
\hline 0 & 1,18 & 1,19 & 1,15 & 1,20 & 1,17 & 1,12 \\
\hline 0,5 & 1,22 & 1,21 & 1,13 & 1,17 & 1,31 & 1,13 \\
\hline 0,5 & 1,22 & 1,21 & 1,11 & 1,17 & 1,32 & 1,16 \\
\hline 0,5 & 1,21 & 1,24 & 1,11 & 1,18 & 1,29 & 1,15 \\
\hline 1 & 1,24 & 1,23 & 1,18 & 1,22 & 1,35 & 1,16 \\
\hline 1 & 1,25 & 1,27 & 1,15 & 1,19 & 1,35 & 1,18 \\
\hline 1 & 1,25 & 1,27 & 1,13 & 1,24 & 1,36 & 1,18 \\
\hline 2 & 1,28 & 1,24 & 1,23 & 1,26 & 1,42 & 1,18 \\
\hline 2 & 1,28 & 1,24 & 1,16 & 1,22 & 1,43 & 1,18 \\
\hline 2 & 1,28 & 1,28 & 1,18 & 1,28 & 1,43 & 1,19 \\
\hline 4 & 1,32 & 1,25 & 1,33 & 1,31 & 1,50 & 1,21 \\
\hline 4 & 1,32 & 1,25 & 1,27 & 1,32 & 1,43 & 1,20 \\
\hline 4 & 1,32 & 1,29 & 1,25 & 1,37 & 1,51 & 1,23 \\
\hline 6,5 & 1,34 & 1,27 & 1,46 & 1,38 & 1,60 & 1,21 \\
\hline 6,5 & 1,34 & 1,25 & 1,29 & 1,35 & 1,55 & 1,23 \\
\hline 6,5 & 1,34 & 1,30 & 1,37 & 1,41 & 1,61 & 1,25 \\
\hline 10 & 1,37 & 1,27 & 1,57 & 1,46 & 1,71 & 1,25 \\
\hline 10 & 1,36 & 1,25 & 1,33 & 1,44 & 1,62 & 1,25 \\
\hline 10 & 1,36 & 1,30 & 1,51 & 1,43 & 1,70 & 1,28 \\
\hline 15 & 1,39 & 1,27 & 1,74 & 1,57 & 1,80 & 1,29 \\
\hline 15 & 1,39 & 1,25 & 1,53 & 1,54 & 1,70 & 1,29 \\
\hline 15 & 1,39 & 1,30 & 1,66 & 1,54 & 1,79 & 1,27 \\
\hline 20 & 1,41 & 1,28 & 1,93 & 1,68 & 1,91 & 1,32 \\
\hline 20 & 1,41 & 1,26 & 1,66 & 1,64 & 1,81 & 1,32 \\
\hline 20 & 1,39 & 1,31 & 1,86 & 1,64 & 1,86 & 1,31 \\
\hline 25 & 1,45 & 1,32 & 2,15 & 1,76 & 1,94 & 1,34 \\
\hline 25 & 1,44 & 1,27 & 1,86 & 1,70 & 1,88 & 1,36 \\
\hline 25 & 1,43 & 1,31 & 2,03 & 1,78 & 1,97 & 1,34 \\
\hline 30 & 1,46 & 1,27 & 2,28 & 1,86 & 1,96 & 1,35 \\
\hline 30 & 1,47 & 1,26 & 2,09 & 1,76 & 1,90 & 1,37 \\
\hline 30 & 1,45 & 1,31 & 2,25 & 1,86 & 2,05 & 1,35 \\
\hline 40 & 1,51 & 1,32 & 2,73 & 2,06 & 2,17 & 1,40 \\
\hline 40 & 1,51 & 1,27 & 2,52 & 1,82 & 2,14 & 1,42 \\
\hline 40 & 1,49 & 1,32 & 2,61 & 2,10 & 2,26 & 1,42 \\
\hline 50 & 1,54 & 1,33 & & 2,22 & 2,37 & 1,45 \\
\hline 50 & 1,55 & 1,30 & & 1,89 & 2,34 & 1,45 \\
\hline 50 & 1,52 & 1,33 & & 2,22 & 2,43 & 1,47 \\
\hline
\end{tabular}


APÊNDICE 10 Dados originais do aumento da vazão (litro/min) e do tempo (Hora) para alcançar os níveis de desgaste $0,5,10,20,30,40$ e $50 \%$, para as três repetições nos diferentes bicos, utilizando o abrasivo Óxido de Alumínio Branco (FFF).

\begin{tabular}{|c|c|c|c|c|c|c|c|c|c|c|c|}
\hline Hora & cer. XR & Hora & cer. ADI & Hora & kem UF & Hora & kem LD & Hora & aço i. XR & Hora & aço i. DG \\
\hline 0 & 1,14 & 0 & 1,17 & 0 & 1,14 & 0 & 1,18 & 0 & 1,17 & 0 & 1,1 \\
\hline 0 & 1,14 & 0 & 1,17 & 0 & 1,14 & 0 & 1,19 & 0 & 1,17 & 0 & 1,1 \\
\hline 0 & 1,14 & 0 & 1,17 & 0 & 1,14 & 0 & 1,18 & 0 & 1,18 & 0 & 1,1 \\
\hline 0,1 & 1,17 & 0,8 & 1,2 & 0,1 & 1,06 & 0,1 & 1,13 & 0,025 & 1,23 & 0,1 & 1,13 \\
\hline 0,1 & 1,17 & 0,8 & 1,2 & 0,1 & 1,08 & 0,1 & 1,17 & 0,025 & 1,24 & 0,1 & 1,13 \\
\hline 0,1 & 1,17 & 0,8 & 1,19 & 0,1 & 1,07 & 0,1 & 1,16 & 0,025 & 1,24 & 0,1 & 1,14 \\
\hline 0,2 & 1,18 & 2 & 1,21 & 0,2 & 1,09 & 0,2 & 1,18 & 0,05 & 1,27 & 0,2 & 1,14 \\
\hline 0,2 & 1,18 & 2 & 1,21 & 0,2 & 1,09 & 0,2 & 1,21 & 0,05 & 1,27 & 0,2 & 1,14 \\
\hline 0,2 & 1,18 & 2 & 1,2 & 0,2 & 1,09 & 0,2 & 1,22 & 0,05 & 1,27 & 0,2 & 1,15 \\
\hline 0,4 & 1,19 & 3,4 & 1,21 & 0,4 & 1,12 & 0,3 & 1,22 & 0,075 & 1,29 & 0,3 & 1,15 \\
\hline 0,4 & 1,19 & 3,4 & 1,22 & 0,4 & 1,15 & 0,3 & 1,24 & 0,075 & 1,29 & 0,3 & 1,15 \\
\hline 0,4 & 1,18 & 3,4 & 1,21 & 0,4 & 1,14 & 0,3 & 1,27 & 0,075 & 1,3 & 0,3 & 1,16 \\
\hline 1 & 1,2 & 4,3 & 1,22 & 0,5 & 1,14 & 0,4 & 1,24 & 0,15 & 1,35 & 0,4 & 1,16 \\
\hline 1 & 1,2 & 4,3 & 1,22 & 0,5 & 1,18 & 0,4 & 1,27 & 0,15 & 1,34 & 0,4 & 1,16 \\
\hline 1 & 1,2 & 4,3 & 1,21 & 0,5 & 1,16 & 0,4 & 1,3 & 0,15 & 1,36 & 0,4 & 1,17 \\
\hline 2 & 1,22 & 5,9 & 1,22 & $\mathbf{0 , 7}$ & 1,2 & 0,5 & 1,29 & 0,225 & 1,39 & 0,5 & 1,16 \\
\hline 2 & 1,22 & 5,9 & 1,23 & 0,7 & 1,2 & 0,5 & 1,3 & 0,225 & 1,39 & 0,5 & 1,16 \\
\hline 2 & 1,22 & 5,9 & 1,22 & 0,7 & 1,19 & 0,5 & 1,32 & 0,225 & 1,4 & 0,5 & 1,18 \\
\hline 3,4 & 1,24 & 9,5 & 1,23 & 0,8 & 1,23 & 0,7 & 1,35 & 0,275 & 1,41 & 0,8 & 1,18 \\
\hline 3,4 & 1,24 & 9,5 & 1,23 & 0,8 & 1,23 & 0,7 & 1,36 & 0,275 & 1,41 & 0,8 & 1,18 \\
\hline 3,4 & 1,24 & 9,5 & 1,23 & 0,8 & 1,23 & 0,7 & 1,36 & 0,275 & 1,42 & 0,8 & 1,21 \\
\hline 4,3 & 1,25 & 11 & 1,23 & 0,9 & 1,25 & 0,9 & 1,38 & 0,475 & 1,48 & 1,1 & 1,21 \\
\hline 4,3 & 1,25 & 11 & 1,24 & 0,9 & 1,26 & 0,9 & 1,4 & 0,475 & 1,48 & 1,1 & 1,21 \\
\hline 4,3 & 1,25 & 11 & 1,23 & $\mathbf{0 , 9}$ & 1,25 & 0,9 & 1,4 & 0,475 & 1,49 & 1,1 & 1,21 \\
\hline 5,15 & 1,26 & 20 & 1,25 & 1,1 & 1,29 & 1,1 & 1,41 & 0,575 & 1,51 & 1,6 & 1,22 \\
\hline 5,15 & 1,25 & 20 & 1,25 & 1,1 & 1,28 & 1,1 & 1,42 & 0,575 & 1,51 & 1,6 & 1,22 \\
\hline 5,15 & 1,26 & 20 & 1,24 & 1,1 & 1,28 & 1,1 & 1,43 & 0,575 & 1,52 & 1,6 & 1,23 \\
\hline 8,75 & 1,29 & 25 & 1,25 & 1,5 & 1,33 & 1,3 & 1,46 & 0,65 & 1,53 & 3,05 & 1,25 \\
\hline 8,75 & 1,29 & 25 & 1,26 & 1,5 & 1,34 & 1,3 & 1,46 & 0,65 & 1,53 & 3,05 & 1,25 \\
\hline 8,75 & 1,29 & 25 & 1,25 & 1,5 & 1,35 & 1,3 & 1,47 & 0,65 & 1,53 & 3,05 & 1,26 \\
\hline 11 & 1,31 & 35 & 1,27 & 1,8 & 1,37 & 1,6 & 1,5 & 1 & 1,62 & 3,8 & 1,26 \\
\hline 11 & 1,3 & 35 & 1,27 & 1,8 & 1,37 & 1,6 & 1,51 & 1 & 1,62 & 3,8 & 1,26 \\
\hline 11 & 1,3 & 35 & 1,26 & 1,8 & 1,38 & 1,6 & 1,51 & 1 & 1,63 & 3,8 & 1,27 \\
\hline 20 & 1,35 & 45 & 1,28 & 2,3 & 1,44 & 1,8 & 1,53 & 1,1 & 1,64 & 7,4 & 1,29 \\
\hline 20 & 1,34 & 45 & 1,28 & 2,3 & 1,45 & 1,8 & 1,54 & 1,1 & 1,64 & 7,4 & 1,3 \\
\hline 20 & 1,35 & 45 & 1,27 & 2,3 & 1,48 & 1,8 & 1,55 & 1,1 & 1,65 & 7,4 & 1,31 \\
\hline
\end{tabular}

Continua . . . 
Continuação.

APENDICE 10 Dados originais do aumento da vazão (litro/min) e do tempo (Hora) para alcançar os níveis de desgaste $0,5,10,20,30,40$ e $50 \%$, para as três repetições nos diferentes bicos, utilizando o abrasivo Oxido de Alumínio Branco (FFF).

\begin{tabular}{|c|c|c|c|c|c|c|c|c|c|c|c|}
\hline Hora & cer. XR & Hora & cer. ADI & Hora & kem UF & Hora & kem LD & Hora & aço i. XR & Hora & aço i. DG \\
\hline 25 & 1,37 & 50 & 1,28 & 2,5 & 1,48 & 2,25 & 1,57 & 1,6 & 1,76 & 9,4 & 1,31 \\
\hline 25 & 1,37 & 50 & 1,28 & 2,5 & 1,49 & 2,25 & 1,58 & 1,6 & 1,76 & 9,4 & 1,31 \\
\hline 25 & 1,37 & 50 & 1,28 & 2,5 & 1,5 & 2,25 & 1,6 & 1,6 & 1,78 & 9,4 & 1,32 \\
\hline 35 & 1,42 & 60 & 1,29 & 2,85 & 1,53 & 2,6 & 1,61 & & & 11 & 1,32 \\
\hline 35 & 1,42 & 60 & 1,29 & 2,85 & 1,54 & 2,6 & 1,62 & & & 11 & 1,32 \\
\hline 35 & 1,42 & 60 & 1,28 & 2,85 & 1,56 & 2,6 & 1,63 & & & 11 & 1,32 \\
\hline 45 & 1,47 & & & 2,95 & 1,55 & 2,9 & 1,65 & & & 20 & 1,35 \\
\hline 45 & 1,47 & & & 2,95 & 1,57 & 2,9 & 1,66 & & & 20 & 1,35 \\
\hline 45 & 1,46 & & & 2,95 & 1,56 & 2,9 & 1,66 & & & 20 & 1,35 \\
\hline 50 & 1,49 & & & 3,1 & 1,59 & 3,4 & 1,72 & & & 25 & 1,36 \\
\hline 50 & 1,49 & & & 3,1 & 1,6 & 3,4 & 1,7 & & & 25 & 1,36 \\
\hline \multirow[t]{13}{*}{50} & 1,48 & & & 3,1 & 1,6 & 3,4 & 1,71 & & & 25 & 1,36 \\
\hline & & & & 3,6 & 1,72 & 4 & 1,78 & & & 35 & 1,38 \\
\hline & & & & 3,6 & 1,7 & 4 & 1,78 & & & 35 & 1,39 \\
\hline & & & & 3,6 & 1,72 & 4 & 1,79 & & & 35 & 1,38 \\
\hline & & & & & & & & & & 45 & 1,4 \\
\hline & & & & & & & & & & 45 & 1,41 \\
\hline & & & & & & & & & & 45 & 1,4 \\
\hline & & & & & & & & & & 50 & 1,41 \\
\hline & & & & & & & & & & 50 & 1,42 \\
\hline & & & & & & & & & & 50 & 1,41 \\
\hline & & & & & & & & & & 60 & 1,42 \\
\hline & & & & & & & & & & 60 & 1,44 \\
\hline & & & & & & & & & & 60 & 1,43 \\
\hline
\end{tabular}

* Os valores em negrito se referem ao tempo necessário para alcançar os níveis de desgaste prédeterminados. 